

\section{IFRA-Nigeria}

French Institute for Research in Africa, Nigeria | Institut français de

IFRA-Nigeria

recherche en Afrique, Nigeria

\section{Transnational Islam}

Circulation of religious Ideas, Actors and Practices between Niger and Nigeria

\section{Élodie Apard (dir.)}

DOI: 10.4000/books.ifra.1713

Publisher: IFRA-Nigeria, African Studies Centre

Place of publication: Ibadan

Year of publication: 2020

Published on OpenEdition Books: 22 July 2021

Series: WAPOSO Series

Electronic EAN: 9791092312560

\section{OpenEdition}

\section{Books}

https://books.openedition.org

\section{Printed version}

EAN (Print version): 9789054481843

Number of pages: $x i-218$

\section{Electronic reference}

APARD, Élodie (ed.). Transnational Islam: Circulation of religious Ideas, Actors and Practices between Niger and Nigeria. New edition [online]. Leiden, Ibadan: IFRA-Nigeria, 2020 (generated 01 février 2022). Available on the Internet: <http://books.openedition.org/ifra/1713>. ISBN: 9791092312560 . DOI: https://doi.org/10.4000/books.ifra.1713. 


\section{ABSTRACTS}

At the crossroads of major trade routes and characterised by intense human circulations, the area that encompasses northern Nigeria and southern Niger is a privileged space to study transnational religious dynamics. Islam is, indeed, an essential feature of this region assuming today new forms in terms of discourses, practices, and modes of dissemination. In order to capture their changing complexity and diversity, regional Islamic dynamics need to be observed from both sides of the Niger-Nigeria border, where religious patterns echo each other but also obey different socio-political injunctions. While studying the processes of religious renewal and mutation, it is necessary to pay attention to the varied forms these processes take, to their direct and indirect effects and to the channels of transmission used.

An interdisciplinary team of seven researchers from Niger, Nigeria, France and the United Kingdom was set up to conduct this transnational study; all authors carried out ethnographic fieldwork in both countries while constantly exchanging, comparing and discussing their respective findings with each other. Thus, this book provides first-hand material collected in the field, that contributes to enrich the reflexion on contemporary transformation dynamics in the Islamic landscapes of Niger and Nigeria, but also reflects the relevance of a transnational and comparative approach of these phenomena. Finally, it showcases the collaborative work of African and European scholars from Francophone and Anglophone countries - a type of scientific partnership unprecedented in this field.

\section{ÉLODIE APARD (DIR.)}

Élodie Apard is a Historian. She holds a PhD from Université Paris 1 PanthéonSorbonne, for which she wrote a doctoral dissertation on the transmission of the Colonial State in Niger. She held the position of Researcher / Scientific Resident at IFRA-Nigeria from 2011 to 2015 and assumed the position of Director of the Institute from 2016 to 2020. She specializes in the study of political processes in the Sahel and the analysis of cross-border movements, including religious movements, as well as the evolution of Boko Haram in Nigeria and neighbouring countries. 

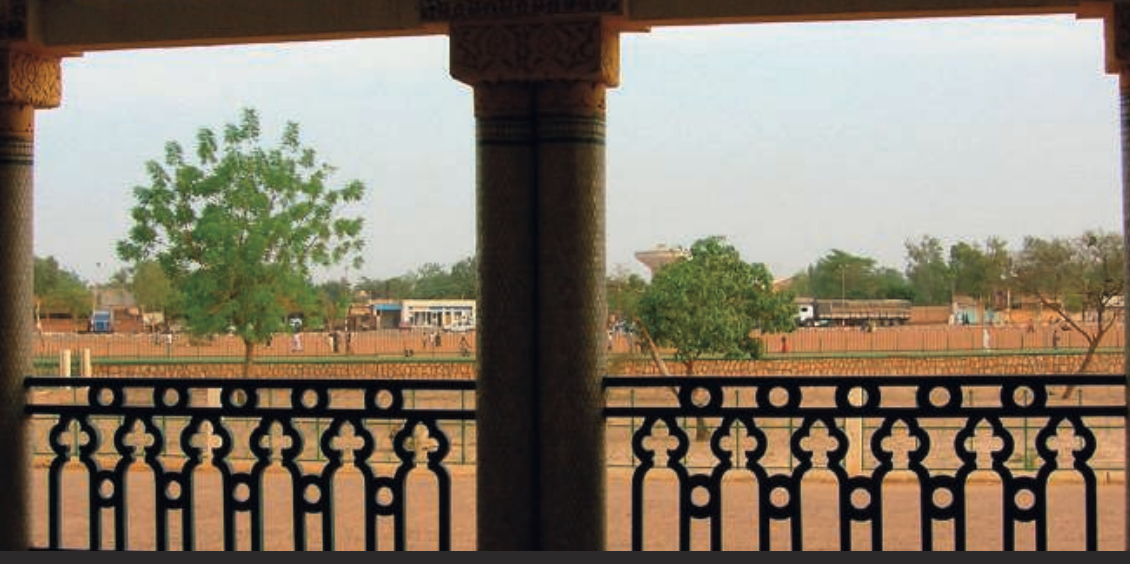

Transnational Islam

Circulation of religious ideas, actors and practices between

Niger and Nigeria

Elodie Apard (ed.)

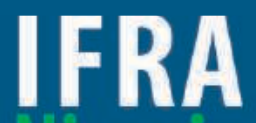

African Studies Centre

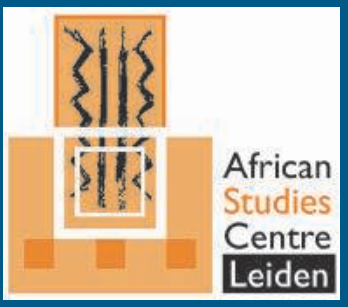





\section{Transnational Islam}

Circulation of religious Ideas, Actors and Practices between Niger and Nigeria 



\author{
African Studies Centre (ASC) \\ Institut Français de Recherche en Afrique (IFRA) \\ West African Politics and Society Series, Vol. 4
}

\title{
Transnational Islam
}

\section{Circulation of religious Ideas, Actors and Practices between Niger and Nigeria}

Edited by

Elodie Apard 
Published by:

African Studies Centre

P.O. Box 9555

2300 RB Leiden

asc@ascleiden.nl

www.ascleiden.nl

French Institute for Research in Africa / Institut Français de Recherche en Afrique (IFRA-Nigeria)

University of Ibadan

Ibadan, Oyo State

Nigeria

www.ifra-nigeria.org

Cover design: Heike Slingerland

Cover photo: Elodie Apard

Maps: Vincent Hiribarren

Printed by Ipskamp Printing, Enschede

ISSN: $2213-5480$

ISBN: 978-90-5448-184-3

(C) Elodie Apard, 2020 


\section{Contents}

LIST OF MAPS vii

LIST OF PHOTOS vii

LIST OF CONTRIBUTORS viii

FOREWORD $x$

INTRODUCTION: STUDYING ISLAMIC DYNAMICS FROM A NIGER-NIGERIA

TRANSNATIONAL PERSPECTIVE $I$

Elodie Apard

PART 1: ISLAM WITHIN THE STATE, ISLAM WITHIN THE SPACE

1 REFORMist ISLAM, THE STATE, AND MUSLIMS OF NiGERIA AND THE REPUBLIC OF NIGER 11

Muhammadu Mustapha Gwadabe

2 ISLAMIC LEGAL RADICALISM: THE CASES OF KATSINA AND

MARADI 39

Abdourahmane Idrissa

Insert A IsLAMIC NGOS IN NIGER AND NIGERIA 67

Marc-Antoine Pérouse de Montclos

PART II QuestionNING THE SALAFI MODEL AND ITS CROSSBORDER EFFECTS

3 CROSS-BORDER PREACHING BETWEEN NORTHERN NIGERIA AND NigER: PRACTICES, ACTORS, AND IMPLICATIONS OF WA'AZI 73 Abdoulaye Sounaye 
4 'RAPPING ISLAM': THE NIGÉRIEN MUSIC SCENE AND THE CHALLENGES OF RELIGIOUS REFORMISM 95

Élodie Apard

5 PASTORALISM AND ISLAMIC PRACTICE IN FULBE COMMUNITIES OF NORTHERN NIGERIA AND NIGER 117 Adam Higazi

\section{PART III BOKO HARAM, THE TRANS-NATIONALISATION OF A LOCAL PHENOMENON}

6 THE SPREAD OF JIHADIST INSURRECTIONS IN NIGER AND NIGERIA: AN ANALYSIS BASED ON THE CASE OF BOKO HARAM 152 Marc-Antoine Pérouse de Montclos

Insert B BOKO HARAM'S RECRUITMENT PROCESSES: IDEOLOGICAL AND PRAGMATIC CONSIDERATIONS 180 Élodie Apard

7 BOKO HARAM ALONG THE NIGERIA-NIGER BORDERLANDS: INFLUENCES, SCOPE, AND MANAGEMENT 185 Kyari Mohammed

Insert C THE STRUCTURE AND ORGANIZATION OF BOKO HARAM UP TO 2015201 Adam Higazi

APPENDIX 205

Translated Islamic Sermons 


\section{List of maps}

Map 1. Geographical distribution of fieldwork 7

Map 2. Geographical distribution of Gwabade's fieldwork 12

Map 3. Geographical distribution of Idrissa's fieldwork 40

Map 4. Geographical distribution of Sounaye's fieldwork 74

Map 5. Geographical distribution of Apard's fieldwork 96

Map 6. Geographical distribution of Higazi's fieldwork 119

Map 7. Geographical distribution of Pérouse de Montclos' fieldwork 154

Map 8. Geographical distribution of Kyari's fieldwork 186

\section{List of photos}

Photo 1. A Karatun Zaure session, in Katsina town 23

Photo 2. Sheikh Sani Dan'auta, Maradi, Republic of Niger 23

Photo 3. Preachers during a wa'azin kasa in Maradi, south Niger 85

Photo 4. Public at a wa'azin kasa in Maradi 88

Photo 5. A DVD shop in Niamey 100

Photo 6. 'Islamic sermons' DVDs for sale in Niamey 100

Photo 7. Screenshot of Goulam's music video 'Ma soeur' 113

Photo 8. Mosque and elderly sheikh in Gelohoy, south-west Niger 124

Photo 9. Cattle market in Illela, Sokoto State, on the Niger-Nigeria border 127

Photo 10. Herds in Maradi Region, south Niger 137

Photo 11. Banner with pictures of Boko Haram suspects 159

Photo 12. Kablewa Refugee Camp, Nguigmi, Diffa Region 195

Photo 13. Internal Displaced Persons' tents in Kablewa Camp 195

Photo 14. DVD covers of transcribed sermons 205 


\section{List of contributors}

Mustapha Gwadabe is a Professor of Political History. He has been teaching in the Department of History at Ahmadu Bello University in Zaria since 1992. He is a Research Fellow at the Centre of African Studies, University of London. During his $\mathrm{PhD}$, he worked on the colonial history of the city of Kano and published Kano Emirate under Colonial Rule, 1903-1953. He now specializes in Islamic dynamics in Nigeria, the Tidjaniyya brotherhood, and relationships with the Izala reformists.

Marc-Antoine Pérouse de Montclos holds a PhD in Political Science from the Institut d'études politiques de Paris (IEP), where he teaches. He is Head of Research at the Institut de recherche pour le développement (IRD) and works on armed conflicts, forced displacements, and the assessment of humanitarian aid in Sub-Saharan Africa. He has lived for several years in Nigeria, South Africa, and Kenya and has published a large number of books, including Boko Haram: Islamism, Politics, Security, and the State in Nigeria (2015).

Mohammed Kyari is a Historian who first studied the Borno region. He then specialized on religious movements and federalism. Professor Kyari has published extensively on Boko Haram and the issue of violent radicalism in Nigeria. He was the Vice-Chancellor of Modibbo Adama University of Technology in Yola between 2015 and 2019 and is now the Vice-Chancellor of the Nigerian Army University.

Abdoulaye Sounaye is Head of Research at the Zentrum Moderner Orient in Berlin as well as a Researcher at Lasdel (Laboratoire d'Etudes et de Recherche sur les dynamiques sociales et le développement local), Nialey. He holds a $\mathrm{PhD}$ in Religious Studies / Anthropology from Northwestern University (USA). His many publications on Islam in Niger include research on secularism, the relationship between gender and religion, Islamic renewal, political Islam, the links between Islam and development, and between media and religion, as well as Salafist doctrines and discourse.

Abdourahmane Idrissa holds a PhD in Political Sciences from the University of Florida. His research focuses on issues related to political Islam and democratization, and on the political economy of regional integration in West Africa. Among his many publications - articles and books, in English and French - he is the co-author of the Historical Dictionary of Niger and Democratic Struggle, Institutionnal Reform and the State Resilience in the African Sahel. He is a Senior Researcher at the African Studies Center, Leiden University.

Élodie Apard is a Historian. She holds a PhD from Université Paris 1 Panthéon-Sorbonne, for which she wrote a doctoral dissertation on the transmission of the Colonial State in Niger. She held the position of Researcher / Scientific Resident at IFRA-Nigeria from 2011 to 2015 and assumed the position of Director of the Institute from 2016 to 2020. She specializes in the study of political processes in the Sahel and the analysis of cross- 
border movements, including religious movements, as well as the evolution of Boko Haram in Nigeria and neighbouring countries.

Adam Higazi is an Anthropologist with a $\mathrm{PhD}$ from Oxford University. He was a Research Fellow at Kings' College, University of Cambridge, from 2010-14, then the Department of Anthropology, University of Amsterdam, from 2016. He is also a Research Fellow at Modibbo Adama University of Technology in Yola. He specializes on Nigeria's central zone (Middle Belt), where he has been conducting fieldwork at doctoral and postdoctoral levels since 2005 . He has also carried out fieldwork in all six states of northeastern Nigeria, including on Boko Haram. An important aspect of his research has been on pastoral Fulani communities across northern Nigeria and in neighbouring countries. 


\section{Foreword}

This book is the result of collective work carried out from 2014 to 2017 by a team of seven researchers as part of the Trans-Islam research programme. Developed and implemented by IFRA-Nigeria (Institut Français de Recherche en Afrique, based in Ibadan), Trans-Islam aimed to study cross-border religious dynamics in an area encompassing northern Nigeria and southern Niger. The project, which brings together European and African researchers, historians, anthropologists, and political scientists, was submitted to the CSFRS ${ }^{1}$ as part of a non-thematic call for proposals. Trans-Islam was fully funded by the CSFRS, which enabled its research team to conduct lengthy field investigations and collect a rich set of primary and original data.

Initially, the project was intended to be coordinated from IFRA's office in Zaria, northern Nigeria. However, security developments, increased attacks, and a high risk of kidnapping led to the closure of the office. Researchers were nevertheless able to carry on with their fieldwork, even in difficult-to-reach areas such as the Nigerian states of Borno and Adamawa, which were still in a state of emergency at the time. The project was thus coordinated from IFRA's headquarters in Ibadan, south-west Nigeria, but the team met annually for research meetings in Niamey, Niger, and Yola, the capital of Adamawa State, north-east Nigeria.

For two years, the seven researchers on the team - two from Nigeria, two from Niger, two from France, and one from the UK - conducted fieldwork in both Niger and Nigeria, sometimes for several months in a row. The innovative nature of this project lays in the emphasis on fieldwork and its long duration, in the originality of the data collected, and in the comparative perspective that was central to the research. The aim was to find a common resonance in the phenomena studied on both sides of the border, but also to highlight the contextual differences in the two countries - in particular, in terms of their respective institutional cultures, the nature of their colonial heritage, and their relationship with the state. These differences partly account for the specific developments of some phenomena in one country or the other.

While English and French were the two main working languages, Hausa was also used, as it is spoken fluently by most of the team members. This common

Conseil Supérieur de la Formation et la Recherche Stratégiques (Superior Council for Strategic Research and Training) is a public interest grouping based in Paris that brings together several French ministries and research and training institutions. 
asset made it possible for researchers to collect, exchange, and analyse as a team many documents produced in Hausa, thus building a corpus of original sources.

Each of the contributions presented here is part of a cross-border perspective that has so far been rarely adopted in studies conducted on Islam in Niger or Nigeria $^{2}$. One of the objectives of this collective work was therefore to bring together French-speaking and English-speaking fields of research which, in West Africa, have long remained compartmentalized.

Builing on this unique approach - at once transnational, comparative, and multidisciplinary - the project has therefore defined, as an objective, the analysis of the religious processes currently at work within the Nigérien-Nigerian space, as well as the dynamics and techniques of transformation / adaptation / appropriation that accompany them. While each topic was chosen individually, the issues were discussed and polished collectively. This approach has made it possible not only to cover a wide range of research questions, but also to shed light on different dimensions of current Islamic dynamics: their social consequences, their political effects, and their impacts on the security situation.

This book presents the results yielded by these two years of fieldwork and two extra years of data compiling, sharing, discussions, and collective reflections.

2 In a collective book entitled Islam, sociétés et politique en Afrique Subsaharienne, (Paris, Les Indes Savantes, 2007), Hassane Souley, Maïkorema Zakari and other specialists of Religion in West Africa looked at the evolution of Islamic dynamics by using case studies from Niger, Nigeria and Senegal but their approach didn't include transnational phenomena. In contrast, William F.S. Miles's book, Hausaland divided: Colonisalism and Independence in Nigeria and Niger (Cornell Univeristy Press, 1994) provides an analysis of colonial and post-colonial experiences on both sides of the border, describing common patterns that includes, but are not limited to, religious pratices. 



\title{
Introduction: Studying Islamic dynamics from a Niger-Nigeria transnational perspective
}

\author{
Élodie Apard
}

The area that now encompasses northern Nigeria and southern Niger has been, from a historical perspective, an area of unrestricted movement of people, goods, and knowledge. In this area, especially from the late eighteenth century, powerful Hausa commercial cities such as Kano, Katsina, Zaria, and Zinder had a broad cultural and economic influence, while the hegemony of the Sokoto Caliphate led to a wide dissemination of specific religious practices and knowledge. ${ }^{1}$ Today, the states of Kebbi, Sokoto, Zamfara, Katsina, Jigawa, Yobe and Borno in northern Nigeria border, respectively, Niger's southern regions of Dosso, Tahoua, Maradi, Zinder and Diffa. These different areas not only have an international border in common, they also have shared histories, strong commercial links and numerous shared cultural features. While being ethno-linguistically diverse, the border regions, both in Nigeria and Niger, use Hausa as a linga franca, particularly convenient in the context of constant trading and intense human circulation.

There is a sizeable Christian minority in these border states, in rural and urban areas, including indigenous Christians ${ }^{2}$, but Islam is the religion of the majority and can be considered as a unifying element for Muslims of different backgrounds. Today, the Islamic religion as practiced in this area takes on new forms and is undergoing changes in terms of discourses, practices, and modes of dissemination. The channels through which religious ideologies are currently relayed between northern Nigeria and southern Niger overlap with the economic and social activities of the region; it is an area of passage, transit, and varied traffic, a crossroads where migratory routes, market activities, and significant financial flows converge. All these exchanges naturally promote the transmission and dissemination of various currents of thought linked to Islam, as well as the discourses and practices they engender. However, since the late 1970s, northern

1 M. Last (1967), The Sokoto Caliphate, (Ibadan History Series) lxxxii, London, Longmans, Green and Co. Ltd., 280 p.

2 E. Apard (2016), « Islam et territoires au Nigéria », Hérodote (158): 86-98. 
Nigeria has been the site of major reconfigurations in the Islamic landscape. The Sufi brotherhoods, notably the Tijaniyya and the Qadiriyya, ${ }^{3}$ which had hitherto been almost hegemonic, were faced with the emergence of reformist currents from Salafists whose rapid development in the 1980s led to strong doctrinaire opposition and competition between different actors.

Influenced by the transformations taking place in the rest of the Muslim world, these religious shifts have had significant social and political impacts at local levels, in both Nigeria and Niger. The Islamic Movement, for example, which emerged in the wake of the Iranian Revolution, defined itself, in the Nigerian context, in opposition to the Nigerian Federal State, following Khomeini's model of transition from democracy to theocracy and refusing any form of compromise with political power. ${ }^{4}$ The reformist Izala ${ }^{5}$ movement, on the other hand, shaped by Salafi ideology, accepted to be part of the secular state in both Nigeria and Niger, practicing entryism and thus infiltrating public spheres in order to transform them from the inside. ${ }^{6}$ The coexistence within the same space of both institutionalized movements and protest groups attests to the presence of different logics of evolution and adaptation that need to be taken into account. Doing so makes it possible to analyse the relationships that these different movements have with each other and with non-religious actors. It also sheds light on their respective functions in the region's socio-political landscape and provides valuable insights for analysing the transition to violence.

When studying the processes of religious renewal and mutation, it is also necessary to pay attention not only to the increasingly complex and varied forms these processes take and to their direct and indirect effects, but also to the channels of transmission used.

Proselytism is probably one of the most obvious tools of religious transformation, and can be observed both in Nigeria and in neighbouring Niger, especially as Nigerian preachers get a very large audience among the Nigérien population. In addition to the constant comings and goings of Nigerian preachers and sheikhs in Niger, there are also very effective popular broadcasting techniques: radio broadcasts, Hausa-language press, cassettes and DVDs, and series of sermons on flash drives or shared on social media networks. While Nigeria produces a huge quantity of all kinds of media, ensuring a wide dissemination of

3 See J-L. Triaud \& D. Robinson, eds, (2005), La Tijâniyya. Une confrérie musulmane à la conquête de l'Afrique, Paris, Khartala, 512 p. and O. Kane \& J-L. Triaud (1998), Islam et islamismes au sud du Sahara. Paris: Editions Karthala, 'Hommes et sociétés', 336 p.

4 M. Dahiru Sulaiman (1998), 'Shiaism and the Islamic Movement in Nigeria - 1979-1991'. In: Ousmane Kane, ed., Islam et islamismes au sud du Sahara, Paris, Editions Karthala, pp. 183-95.

5 Abbreviated version of Jama'at' Izalat' al bid'a' wa' iqamat' al Sunnah ('Society for the Removal of Innovation and Reinstatement of the Sunnah')

6 R. Idrissa (2018), 'Les trajectoires du salafisme politique au Sahel. Le cas du Niger', Politique africaine 1(149): 43-65. 
its religious discourses, Niger also participates in this dynamic by developing its own tools. ${ }^{7}$

The renewal of Islamic ideas and practices is therefore fuelled by this great mobility of people and objects, in multiple spaces, where preachers, but also other social groups, play a key role. Pilgrims, of course, but also students and shopkeepers, for example, whether consciously or unconsciously, act as relays of religious transmission. Similarly, the places where these dynamics can be observed extend well beyond the border area, where many of the actors involved in these transformations cross paths. In every city and village in northern and southern Nigeria and Niger, these phenomena can be seen and heard in schools, markets, mosques, and state institutions. The area under study is therefore ideal for the examination of the evolution of religious dynamics. But some parts of the region have been sites of a jihadist insurrection over the past decade, threatening the stability of states, resulting in tens of thousands of deaths, and muddying our reading of phenomena related to Islam.

The team of researchers who led the Trans-Islam project, which this book results from, focused part of their fieldwork on the transnational aspects of phenomena surrounding Boko Haram's activities. While aware of the problematic hypervisibility of jihadist movements, researchers could not ignore the importance of the Boko Haram insurgency in the region's cross-border dynamics.

After defining the aims and scope of the research, three main themes were chosen to guide the researchers' lines of questioning and these now constitute the three main parts of this book. The first one concerns the place occupied by Islam in Nigérien and Nigerian societies: the way it occupies space, how the relationships between religious actors are reflected on a geographical level, the institutional place of Islam and the nature of its relationship with the state, both in Niger and Nigeria.

Mustapha Gwadabe investigates the historical character of cultural, economic, and religious relationships between regions located on both sides of the border and reminds us that the circulation of Islamic knowledge has had a long history in this area. The historical perspective then provides a background for the study of often conflictual relationships between Sufi brotherhoods - which have been formally established in the region since the beginning of the nineteenth century - and the Salafi-inspired reformist movements that emerged in the second half of the twentieth century. Based on fieldwork carried out in the Nigérien cities of Niamey, Maradi, and Zinder as well as in the Nigerian cities of Zaria, Sokoto, and Katsina, the author emphasizes the role of French and British colonial legacies in shaping religious activities in the public sphere.

A. Sounaye (2011), 'La "discothèque" islamique: CD et DVD au cœur de la réislamisation nigérienne', Ethnographiques.org, No. 22 (May). 
Abdourahmane Idrissa questions the political, institutional, and social differences that characterize two very close and strongly intertwined spaces: the Maradi Region in Niger and that of Katsina in Nigeria. Noting the implementation of Sharia law in the northern Nigerian states and the absence of legal radicalism in Niger, he questions the role of each country's institutional cultures and in particular the secular nature of law, which is perceived very differently on each side of the border.

The second part of the book discusses new ways of thinking about and practising Islam, with a focus on reformist movements and the 're-Islamization' processes ${ }^{8}$ they have introduced. In this section, the analysis focuses on the actors themselves, but also on the discourses and tools used for their dissemination and the social and cultural effects they engender.

Abdoulaye Sounaye analyses the role of public sermons (wa'azi) in the Salafi reformist project, which aims to develop and disseminate transnational moral, social, and religious norms. Having attended numerous sermons in the Nigérien cities of Niamey, Maradi, and Agadez, and then studied the Salafiyya movement in Zaria, the author also considers the socio-political environment, in both Nigeria and Niger, in which reformist discourses are developed and in whose transformation they participate.

The effects of these discourses on Nigérien cultural production are the focus of Élodie Apard's works. She examines the ways in which Salafi moral values are either rejected or, on the contrary, re-appropriated by Niamey's music scene. Analysing the different adaptation strategies developed by artists also raises the question of a social and generational divide that is strongly tied to the political and economic evolution of contemporary Niger.

In the last chapter of this part, Adam Higazi examines the place occupied by Islam in Fulani pastoralist communities in Niger and Nigeria, as well as the continuity or rupture caused by the restructuring of the Islamic landscape, particularly with the spread of the Tijaniyya and, less often, Salafism, into pastoral groups. With an ethnographic study of pastoral communities in Dakoro (Maradi Region) in Niger and Karim Lamido (Taraba State) in Nigeria, the text gives insights into the Islamic practices and education of pastoralists. At the time of fieldwork, the areas studied were less conflictual than other parts of Nigeria and, Niger, and the Sahel, but this study sheds light on processes of social change and of the diversity of Islamic practice among the pastoral Fulani.

The third part of the book is devoted to the transnational aspects of the Boko Haram insurgency. The Niger - Nigeria border area has occupied a central place in the movement's history, from its emergence in the border town of Kanamma in

A. Sounaye (2016), Islam et Modernité. Contribution à l'étude de la ré-islamisation au Niger, Paris, L'Harmattan, $168 \mathrm{p}$. 
northern Yobe to the occurrence of attacks on the four countries bordering Lake Chad. Used for a time as the movement's rear base, south-eastern Niger has since become one of the areas most affected by the conflict outside Nigeria. With the regionalization of the conflict and increased militarization, taking into account the cross-border dimension of the group's activities is essential to our analysis. Also, collecting field data on both sides of the border, however difficult it may be, makes it possible to assess Boko Haram's impacts, particularly in Islamic spheres, and to engage in a comparative study of the Nigérien and Nigerian states' responses to the crisis.

While visiting several border towns between the Diffa region of Niger and Borno State in Nigeria, Kyari Mohammed observed the signs of Boko Haram's presence, its effects on the security and humanitarian situation, and the economic and social consequences of the measures taken by the state to combat the group. In this chapter, the author analyses the specific features of this border area in the group's development strategies and the particular management of these peripheral areas by their respective states. At the outer limits of Nigérien and Nigerian territories, they suffer from the effects of both armed insurrection and historic state neglect.

Marc-Antoine Pérouse de Montclos questions the role played by jihadist movements in the religious evolution of the region and their influence on current trends. While situating Boko Haram within the historical continuity of other forms of Islamic mobilization, the author draws attention to the geopolitical context in which the movement emerged. He places in perspective the influence of Saudi Wahhabism and underlines the role of local actors and networks in the production and dissemination of a counter-discourse.

Three inserts complement and highlight the data - both rich and original collected by members of the research team throughout the project. The first discusses the place of Islamic NGOs in the religious landscape, comparing their roles in Niger and Nigeria. The second insert looks at issues of membership and recruitment related to Boko Haram, which emerged from the interviews conducted with prisoners who had been suspected of being part of the movement, as well as from the arguments developed in the group's propaganda speeches. The rationale behind one's involvement, however, appears to be just as varied as the fighters' personalities, making any attempt at profiling particularly uncertain. Based on interviews with survivors, the third insert offers a description of daily life in areas that came under Boko Haram's control.

The appendices to this book contain a selection of texts extracted from the corpus of sources collected by researchers during their fieldwork and used in their research. These are sermons delivered during public gatherings, which were filmed and then burned on DVDs and have been transcribed and translated from Hausa 
into English. The five sermons that were chosen represent some of the main issues addressed in the book:

- The Tijani argument developed by Sheikh Dahiru Bauchi, used to denounce the practices of Izala, which is a good example of the concrete manifestations of the opposition between Sufis and reformists.

- The sermon delivered by Sheikh Kabiru Gombe in Tahoua (Niger) deals with men's behaviour towards romantic and marital relationships. It underlines the place of morality in the Salafi discourse and also features the preacher's oratory skills.

- Sheikh Abubakar Gero's sermon on the incompatibility between leisure and religious norms, which called for a 're-moralization' of activities that are popular among young people.

- Sermons given by Sheikh Abubakar Gero and Sheikh Kabiru Gombe addressing, respectively, the opposition in terms of religious practices between the 'right path' followed by Salafi and that followed by others, and the importance given to the youth in the Salafi re-Islamization process.

While this book provides original, first-hand material collected in the field and contributes to enriching the reflection on contemporary transformation dynamics in the Islamic landscapes of Niger and Nigeria, it also highlights the relevance of a transnational and comparative approach to these phenomena. Finally, it showcases the collaborative work of African and European scholars from Francophone and Anglophone countries, a type of scientific partnership that is rare in this field. 
Map 1 Geographical distribution of fieldwork

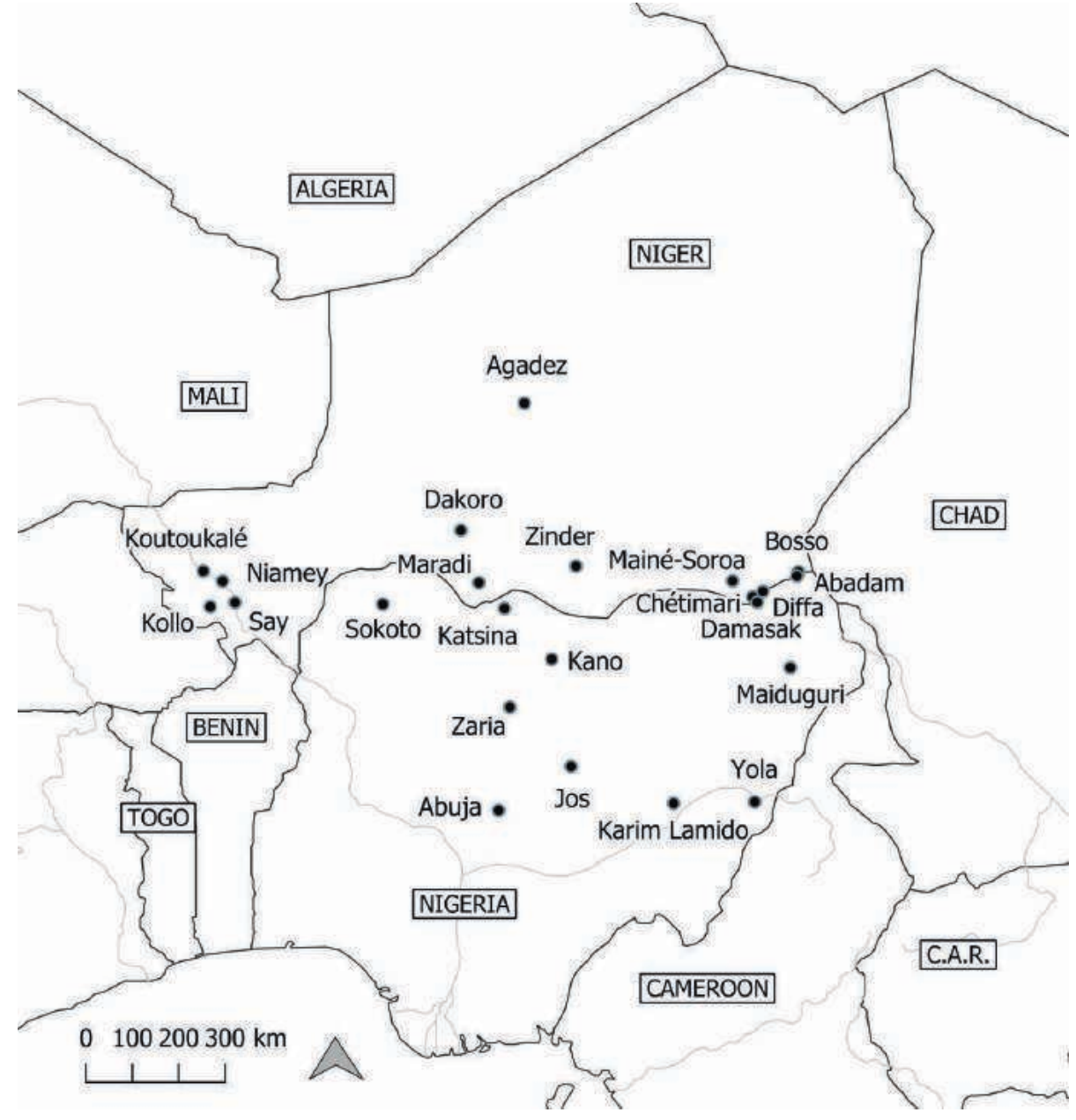





\section{Part I \\ Islam within the State, Islam within the space}





\title{
Reformist Islam, the state, and Muslims of Nigeria and the Republic of Niger
}

\author{
Muhammadu Mustapha Gwadabe
}

\section{Introduction}

The Islamic reform well documented and often cited in this part of West Africa is the 1804 Jihad led by Shaykh Usman Ibn Fodio. ${ }^{1}$ This movement was clearly focused, well defined, and guided by the social and political roles of Sufi religious thought and doctrine. ${ }^{2}$ Studies have established that about 350 books were published by the three key 1804 Jihad leaders alone, explaining various aspects of the jihad's requirements. ${ }^{3}$ These authoritative publications described the philosophy behind the jihad and established that it requires a special set of circumstances to call people to jihad or Islamic reform. In the first place, the leader

1 Much has been written on this subject in Nigeria and abroad. The first Nigerian $\mathrm{PhD}$ from the Department of History at the University of Ibadan was on the Sokoto Caliphate. It was published in both English and Hausa by Longman and Ibrash Islamic Publication Centre, Lagos: M. Last (1967), The Sokoto Caliphate, Ibadan History Series, Longmans, Green and Co. Ltd, London. Many such studies can be found at Ahmadu Bello University Zaria; Usman Dan Fodio University, Sokoto; Bayero University, Kano; University of Maiduguri; and many other Nigerian universities and research centres.

2 This point was raised and argued for by M.S. Umar, 'Sufism and its opponents in Nigeria: The doctrinal and intellectual aspects'. In: Frederick de Jong \& Bernd Radtke eds, (1999), Islamic Mysticism Contested: Thirteen Centuries of Controversies and Polemics, Brill, Leiden, p. 359. Umar quoted one of the authoritative writings of Fodio on the Jihad. For more information on this as quoted by Umar, see Uthman b. Fudi, kitab al-tafriqa bayn al-tasawwuf alladhi li'tahaqqaq wa'lladhi li'l-takhalluq, MS No. 121, Postgraduate Research Centre, Bayero University Library, Kano.

3 The writings of the $1804 \mathrm{Jihad}$ (also called Sokoto Jihad) leaders are still available in their original texts and in English or Hausa translations at the Waziri Junaidu, Sokoto State History Bureau, Sokoto State, Nigeria. They are also available at the Northern History Research Scheme (NHRS) Library, Department of History, Ahmadu Bello University Zaria; Arewa House Centre for Documentation and Historical Research, Ahmadu Bello University, Kaduna; and at other locations within and outside Nigeria. 
must possess the vision to remove the 'veil' (kashf) that covers the sight, to clear away the darkness of the eye and the deafness of the ear so that the heart can cogitate clearly. ${ }^{4}$ This is the distinction between the $19^{\text {th }}$ century reform movements and those of the $20^{\text {th }}$ and indeed $21^{\text {st }}$ centuries. This chapter examines the history of the $20^{\text {th }}$ - and $21^{\text {st }}$-century Islamic reforms in Nigeria and the Republic of Niger and intends to show that the strong relationship between the two communities on matters of the economy, politics, and socio-cultural developments, as well as the historical experiences of these communities, shaped the environment and the forms of their relations, including those of scholarship and learning - and, more recently, their links within the militant insurgency.

Map 2 Geographical distribution of Gwabade's fieldworks

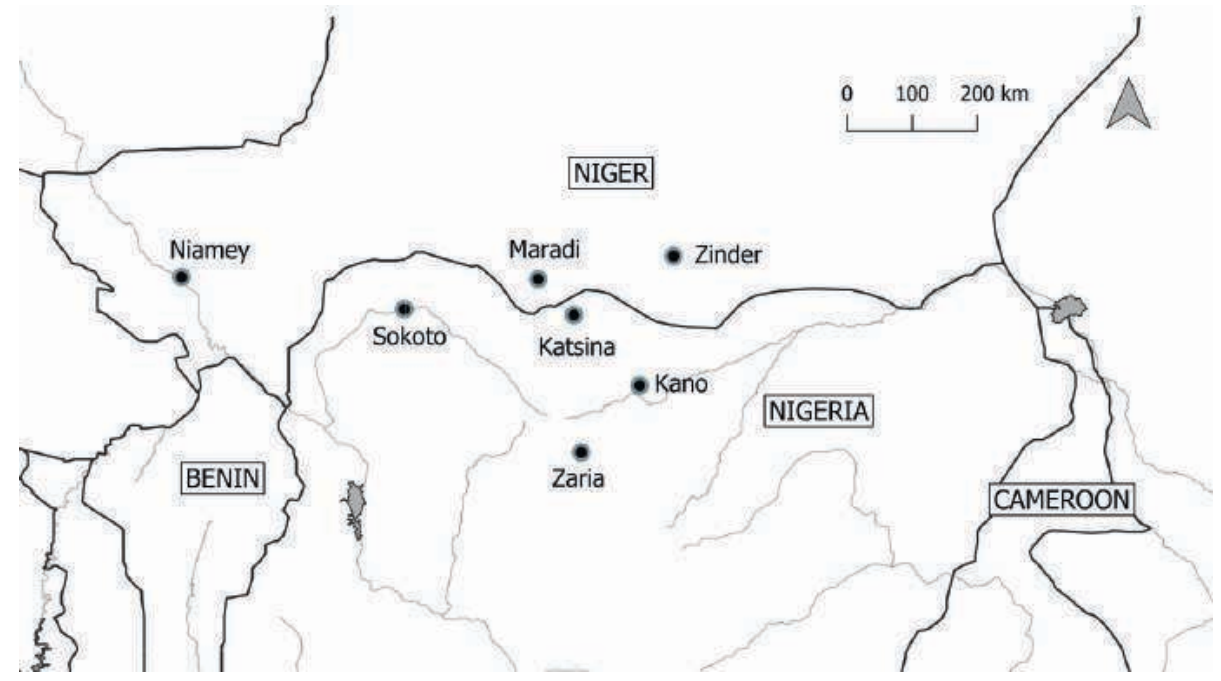

\section{Background}

William F. S. Miles provides a clear description of the relationship between the communities of Nigeria and Niger since precolonial times. ${ }^{5}$ For a very long period in their history, the peoples of Nigeria and Niger have lived together as members

4 M.S. Umar, 'Sufism and its opponents in Nigeria: The doctrinal and intellectual aspects', in op. cit. p. 359.

5 W.F.S. Miles, (1994), Hausaland Divided: Colonialism and Independence in Nigeria and Niger, The Wilder House Series in Politics, History and Culture, Cornell University Press, Ithaca and London, pp. xiii-xvii. 
of the same socio-political and socio-economic community. ${ }^{6}$ Although divided by dissimilar colonial experiences and challenges of modernity, the social network that has bound them together over time remains functional and relevant. ${ }^{7}$ This therefore supports the context of this chapter, which postulates that there is an organic link between the two communities such that a strong wave of influence exists across the border. ${ }^{8}$ In addition to issues of socio-culture, there are interconnected scholarship and learning activities between the countries. Communities of western Sudan benefitted greatly by relating with one another and with centres of learning, particularly in Timbuktu and the Aïr region (Agadez). Knowledge about Islam received a boost when the published writings of leading Islamic scholars spread to most parts of the Sudan. It was indeed the time when Islamic scholarship and learning were clearly focused, with an emphasis on knowledge-building. ${ }^{9}$ The focus was not only on committing to memory the standard texts for the purposes of participation in competition; it also involved shaping and moulding of the student's character by following a defined curriculum, uniformly used throughout the region. ${ }^{10}$ Thus, students overcame large distances to travel to renowned sheikhs to study and learn. Various categories of people traversed many cultures and land regions in order to receive instructions from different teachers, to learn a particular text, or even just to repeat a text already mastered under another teacher. ${ }^{11}$ This was in recognition of the fact that

6 M.G.A Smith, 'Hausa Kingdom: Maradi under Dan Baskore, 1854-75'. In: Daryll Forde \& Kaberry, P.M., eds, West African Kingdoms in the Nineteen Century, International African Institute, Oxford University Press.

7 W.F.S. Miles, op. cit.

8 In Kani's view, the relationship between Hausaland and the rest of Africa, especially North Africa, can be traced to the $15^{\text {th }}$ century. This was when direct contact was established through the trans-Saharan route which connected Kano-Katsina with Tuwat, Ghadamas, and Ghat across Tripolitania and Egypt to Hijaz for the purposes of economic, cultural, diplomatic, and intellectual relations. For further reference, see A.M. Kani (2007), 'The place of Katsina in the intellectual history of Bilad Al-Sudan up to 1800'. In: I.A. Tsiga \& A.U. Adamu, eds, Islam and the History of Learning in Katsina, Spectrum Books Ltd, Ibadan, Nigeria, pp. 24-34

9 This is to borrow what Murray Last refers to as the 'period of book-plenty and book-shortage' to equally argue that the present book shortage could be due to the monopoly of Islamic book publication for political reasons by the Saudi government since the mid- $20^{\text {th }}$ century. As a result, Islamic books are published and sent out free, making competitive publication very challenging. It is therefore not a matter of a book famine or shortage but the politicizaton of Islamic book publication. Last also acknowledged the $15^{\text {th }}$ and $16^{\text {th }}$ centuries as periods of a book-boom that extended from Timbuktu as far as Hausaland and Borno. Similar experience was also noted in the $19^{\text {th }}$ and early $20^{\text {th }}$ centuries in Sokoto and in other areas around the Sokoto Caliphate. For details, refer to M. Last (2011), 'The book and the nature of knowledge in Muslim northern Nigeria, 14572007'. In: Graziano Kratli \& Ghislaine Lydon, eds, The Trans-Saharan Book Trade: Manuscript Culture, Arabic Literacy and Intellectual History in Muslim Africa, Brill, Leiden, Boston, pp. 175-212.

10 Bugaje presented an interesting discussion of some of the contents and outlook of such a type of scholarly tradition. It is this tradition that established Islam and Islamic culture in most parts of the Sudan. For details, see U.M. Bugaje, 'Some reflections on the development of Islamic learning in Katsina 1300-1800 AD’. In: I.A. Tsiga et al., eds, ibid. pp. 80-82.

11 M.N. Katsina, 'A discourse on the intellectual legacies of some pre-Jihad Muslim scholars of Katsina'. In: I.A. Tsiga et. al., eds, ibid. p. 37. 
knowledge resides not just in a text; rather, it is with the scholar. ${ }^{12}$ Most leading scholarly families of Hausaland trace their origin and history of scholarship to this period and process, where they were found moving from one teaching centre (alim) to another. Kani (1997) is explicit on scholars of Yandoto and Birnin Katsina, who, by this time had gained renown in the fields of mathematics, occult sciences (i.e. magic squares, ulum al awfaq), and letter images (ulum al harif). ${ }^{13}$ Another dimension of the relationship lay in what Hunwick recorded: these communities have been profoundly influenced by the culture of Islam. ${ }^{14}$ Through the institution of hajj (pilgrimage to Mecca) and the participation of both individuals and states, an important catalyst was developed that strengthened relationships between the communities of Nigeria and Niger. Such remains the tradition among most West African countries, which made Kano a centre for pilgrimage assistance through the West African Pilgrims Agency. ${ }^{15}$ According to Hunwick, communities of western Sudan have therefore lived as members of a religious community sharing a common world view - one of Islamic notions of self-identity, of group interrelationships, and of the relationship of the divine to the human. ${ }^{16}$ Consequent to these, therefore, to acquire a permit to move across the borders or to even expand the borders demands, at best, reasons of faith and not any particular document. Research on this phenomenon unequivocally emphasizes the point that the borders were not only porous but socio-culturally non-existent. ${ }^{17}$

12 My attention was drawn to this by Professor M.S. Umar while he was describing the traditional schooling and learning methods in Hausaland. Umar is Professor of Islamic History at the Department of History, Ahmadu Bello University, Zaria, Nigeria.

13 Kani, A.M. (1997), 'The place of Katsina in the intellectual history of Bilad Al-Sudan up to 1800'. In: I.A. Tsiga \& A.U. Adamu, eds, Islam and the History of Learning in Katsina, Ibadan, Spectrum Books. Among such individual scholars of Katsina was Muhammad Ibn Muhammad Al Katsinawi Al Fulani, praised by Abdul Rahman Al Jabarati as a cynosure, the theologian, the ocean of learning, the sea of knowledge, the unparalleled, the garden of science and discipline, the treasury of secrets and mysticism. See ibid. p. 30. See also U.M. Bugaje, 'Some reflections on the development of Islamic learning in Katsina 1300-1800 AD’. In: ibid.pp. 79-80.

14 J. Hunwick (1989) 'Borders, boundaries and the concept of State in the Islamic traditions'. In: A.I. Asiwaju \& B.M. Barkindo, eds, The Nigeria-Niger Trans-Border Cooperation, Proceedings of the Workshop held at Bagauda Hotel, Kano, Research and Documentation Centre, National Boundary Commission, Malthouse Press, p. 331.

15 During some of these pilgrimages to Saudi, Shaykh Ibrahim Niasse served as the Amirul Hajj, leading the contingents of West Africa, including the political leaders. It was during one such trip that Shaykh Ibrahim, in the course of discussion, drew the attention of the Prime Minister of Nigeria to the relevance of celebrating the birth of the Prophet and the need for a public holiday to be attached to it. Since then the birth of the Prophet remains a public holiday recognized by the government of Nigeria. This regional outlook of pilgrimage remained the practice until some Islamic groups from Nigeria started to raise objections out of jealousy. This is accepting that religion has also played an important role in establishing the basis of unity in the region, as noted by Hunwick. See for details, J. Hunwick, ibid.

16 Ibid. p. 330.

17 A.I. Asiwaju et al. (1993), eds, ibid. 
Important in this case is therefore the factor of Islam, which recognizes and respects hospitality and the requirement for public spaces for religious practice. ${ }^{18}$ In Islam, what matters is a free environment in which to practise one's religion; thus, the focus is not so much on a political state but on the ummah (community of worshippers). A political state is about territory and people within the limits of that territory; this is contrary to the case of the ummah. The latter concerns the totality of culture and cultural outlook that creates the conditions in which Muslims can have the free space to practise their religion. Thus, when he strongly disagreed with the rulers of Tuat, Al Maghili, a $15^{\text {th }}$-century renowned Islamic scholar, relocated and settled in Bilad al-Sudan, which took him to Kano and Katsina. ${ }^{19}$ The result of this development attracted other famous scholars and produced a scholarly community and a tradition of learning, as well as a new socio-political culture - which helped to create a formidable Islamic state with well-defined institutions. ${ }^{20}$ As a result, a tradition of Islamic scholarship and reform continued in Hausaland and the rest of Bilad al-Sudan in the $16^{\text {th }}$ century, with continued movement and settlement of scholars of repute - such as Shaykh Umar b. Aqit, the grandfather of Ahmad Baba al-Timbukti. ${ }^{21}$ Also present in the region at different times were Al-Shaykh al-Tadhikhti; Makhluf b. Salih al-Bilbali, who was in Katsina in 1509 and was persuaded to serve as Qadi; and Makhluf b. Salih alBilbali, a distinguished scholar from Timbuktu, who was also saddled with the responsibility of serving as Qadi. He died after 1533 at home in Timbuktu. ${ }^{22}$ Thus, by the $17^{\text {th }}$ century, Hausaland and indeed Bilad al-Sudan had developed indigenous Islamic scholars on the basis of whose contributions the $19^{\text {th }}$ century jihad of Usman Danfodio, comprising communities from both Nigeria and Nigérien areas, was made possible. ${ }^{23}$

The discussion in this chapter is of the view that the socio-cultural, political, and economic dynamics that bound precolonial communities of western Sudan into a single system took their roots following these developments. The objective is to show that networks of relationships between the communities of the region

18 Hunwick made the point that Islam has legitimized hijra (migration), and thus Muslims always appreciate environments conducive to religious worship and do not respect boundaries. See ibid. p. 331 .

19 Al Maghili was in Hausaland during the reigns of Muhammad Rumfa of Kano, Muhammad Korau of Katsina, and Muhammad Rabo of Zazzau. The three men were contemporaries and played significant roles in the domestication of Islam in their kingdoms. For details on Al Maghili's intellectual contribution to Islam, see A.M. Kani in I.A. Tsiga \& A.U. Adamu, ibid. pp. 24-34.

20 Another scholar with whom this community was built was Imam Jalal al-din al-Siyuti. He was noted to have contributed much to the consolidation of Islam Bilad al-Terur by issuing fatwas (legal verdicts) to the rulers and scholars on various socio-political and economic issues pertaining to Islam. Discussion on his contributions is well covered in A.M. Kani, op. cit. p. 27.

21 Shaykh Umar was in Hausaland before the death of Sunni Ali, the famous ruler of Songhai in 1492. See ibid. p. 28.

22 A.M. Kani, ibid. pp. 28-31.

23 See Map: The Caliphate area, c. 1800. In: M. Last (1962), The Sokoto Caliphate Area, Longman, Great Britain, p. Lxxi. 
have existed ever since, and these networks involve socio-cultural, political, and economic dimensions. This bond created significant religious harmony and a cultural bloc, a sense of reciprocity as well as of dependence, acculturation, enculturation, and assimilation.

\section{British / French colonial policy on Islam, Islamic scholarship, and learning in Nigeria and Niger Republic}

The 1804 Jihad consolidated the gains of the pre-Jihad developments, creating a political territory - the Sokoto Caliphate - that extended over the current regions of southern Niger and northen Nigeria. Since the political entity that resulted was built on Islam, learning and scholarship in addition to territorial expansion constituted the dominant activities. Thus, communities - especially border towns in today's Nigeria and Niger Republic - related as members of a common territorial entity. ${ }^{24}$ This remained the culture until colonial conquest by the British and French at the commencement of the $20^{\text {th }}$ century. Colonial policy and borders were created to check movement but, ironically, these colonial policies facilitated movement of people across the borders. The British encouragement was not deliberate or intentional; rather, it was in response to the colonial policy design which recognized the existing authority. ${ }^{25}$ Such toleration created space for knowledge seekers and scholars from the Niger area to travel into parts of Nigeria, predominantly to Katsina, Kano, Zaria, Sokoto, and as far as Borno. ${ }^{26}$ Unlike the British, the uncompromising French policy on Islam and Islamic movements in Niger forced the scholarly population to travel elsewhere, and northern Nigeria was the natural solution. ${ }^{27}$ This viewpoint is also shared by Abdoulaye Sounaye,

24 A.A. Kware, 'Barriers or bridges: International border as an instrument of division or unity between the people of Sokoto State (Nigeria) and Konni area/Tahoua State (Niger Republic)', Departmental Seminar, Department of History, Usman Danfodio University, Sokoto.

25 Miles, op. cit. p. 249.

26 M.S. Umar made a detailed study of the British policy in Islamic northern Nigeria that explains the various approaches employed. In his exhaustive study, unlike Miles, Umar shows that the British policy was not all about toleration; it also involved appropriation, containment, and surveillance. For a detailed explanation, see the chapter by M.S. Umar (2000), 'The Tijaniyya and British colonial authorities in northern Nigeria'. In: Jean-Louis Triaud \& David Robinson, eds, La Tijaniyya: Une confrérie musulumane à la conquete de l'Afrique, Karthala, pp. 327-56.

27 Unlike the British under Lugard, whose words helped heal the wounds, the French never expressed regret for the violence meted out on her colonies (Niger) and gave no explicit guarantee of post-conquest religious freedom. The scars left by Captain Voulet and Chanoine were left to fester. See Miles, op. cit. p. 250; L. Brenner (2001), Controlling Knowledge: Religion, Power and Schooling in West African Muslim Society, Indiana University Press, Indiana University, Bloomington. Private discussions with some of the leading scholarly houses in Katsina, Zaria, Kano, Maradi, Niamey, Kuso, Konni, and Tahoua all testify to the hosting of students and scholars alike from Niger, Cameroon, and Chad. 
who noted that the colonial logic of governance greatly contributed to the spread of Islam in both French and British dominions in Africa. ${ }^{28}$

The purpose of British and French colonizing missions was the same, although they differed in their tactics and approaches to policy implementation on governance. More specifically, their approaches to Islam and the attitudes of Islamic scholars differ noticeably. ${ }^{29}$ On the part of the British, as hitherto stated, some level of toleration was exhibited, whereby some sections of the Islamic scholarly community were tolerated and given autonomy, under conditions of appropriation, containment, and surveillance. ${ }^{30}$ The contrary applied in the case of the French, where clear distrust defined the relationship. The French exhibited unrelenting control and restrained the activities of Islamic scholars. Probably because of their difficult experiences of revolts and protests, especially in their North African colonies, the French maintained a strong control over Muslim activities, as well as a fear of Islam in general. ${ }^{31}$

At a more philosophical level, the hostility of France to Islam can be traced to the French Revolution, during which an open aversion to religion was exhibited that separated church from state. ${ }^{32}$ As a result, the Roman Catholic Church was demystified and condemned as obscurantist, feudal, and authoritarian. ${ }^{33}$ It was within this same framework that the Islamic religion was viewed by the French authorities while they were establishing their hold on the colonies. The attempt by Muslim Brotherhoods in Algeria to resist French colonization in the nineteenth century further legitimized French anti-religious views on Islam. This was supported, moreover, by a publication from the French colonial office that served as a model for the administration of French Muslim-dominated colonies. ${ }^{34}$ Following the position of this model, all anti-colonial resistance movements were banned and fought against. This document terminated any permits for religious activities, especially those which challenged the colonial state. Thus, throughout the colonial period, the territory of Niger never had a full-blown brotherhood or

28 A. Sounaye (2012), 'Recognising religion in democratisation processes in Sub-Saharan Africa: A case from Niger', Ciência \& Trópico 36(1): 45-72.

29 W.S.F. Miles, op. cit. Hausaland Divided: Colonialism and independence in Nigeria and Niger, p. 24951.

30 M.S. Umar, op. cit. p. 330.

31 J-L. Triaud (1995), La légende noire de la Sanûsiyya. Une confrérie saharienne sous le regard français, 1840-1930, Paris, Maison des Sciences de l'Homme, 1154 p.

32 H. Gough (1998), The Terror in the French Revolution, Studies in European History, Macmillan Press Limited.

33 Triaud, op. cit.

34 This was from a book published in 1846 by a military officer (Capitaine de Neveu) of the Staff Head Quarters and a member of the Scientific Commission of Algeria. The book was titled Les khouans : ordres religieux musulmans d'Algérie. 
marabout structure / culture comparable to the ones in Senegal or Nigeria. ${ }^{35}$ Indeed, the French were so careful that even the threat of an individual cleric was not permitted under their rule. ${ }^{36}$ As noted earlier, movement into Nigeria became the natural option for both Nigérien Islamic scholars and students seeking Islamic knowledge. From this point of view it is obvious that the French colonial policy on Islam also encouraged the relocation and settlement of the Muslim scholarly population from Niger into northern Nigeria. More specifically, a large number of both scholars and students were found settled in different places within Katsina, Sokoto, Kano, Zaria, and Borno. These communities were renowned for a welldeveloped culture of Islamic learning. Other salient factors that aided the continued movement into northern Nigeria from Niger included the threat of droughts and a number of basic socio-cultural ties. ${ }^{37}$ In summary, therefore, in addition to the precolonial historical unity of the territories, the French colonial antagonism to Islam and Islamic scholarship, coupled with the British colonial policy of toleration, contributed to the continued scholarly relationship between the communities of Nigeria and the Republic of Niger.

Developments in Islamic scholarship and learning in northern Nigeria have been well studied by numerous researchers. ${ }^{38}$ The obvious historical fact is that the British met a well-established culture of scholarship and learning, one which it was difficult to abandon. The dominant culture was that of Sufi orientation, represented by Qadiriyya and Tijaniyya brotherhoods. ${ }^{39}$ Of significance in the Sufi tradition is the increasing search for knowledge and for closeness to God, and the purification of the heart for total submission to the will of God. To achieve this state of mind involves a constant search for knowledge, which explains the establishment of a number of schools and centres of worship (mosques / zawiyyah). ${ }^{40}$ It also demands

35 R. Loimeier, (1999), 'Political dimensions of the relationship between Sufi brotherhoods and the Islamic reform movements in Senegal'. In: Frederick de Jong \& Bernd Radtke, Islamic Mysticism Contested: Thirteen Centuries of Controversies and Polemics, Brill, Leiden, pp. 341-56.

36 Miles, op. cit.

37 J.O. Odihi, 'Nigeria-Niger trans-border crossing during environmental crisis: Towards planning for disaster migration'. In: Asiwaju, A.I. \& Barkindo, B.M. The Nigeria-Niger Trans-Border Cooperation, Research and Publication Committee, National Boundary Commission, Proceedings of the Workshop held at Bagauda HotelKano, 2-8 July 1989, pp. 169-77.

38 M.S. Umar made a list of such research studies covering the subject and period. For details, refer to his chapter titled 'Sufism and its opponents in Nigeria: The doctrinal and intellectual aspects'. In: Frederick de Jong \& Bernd Radtke (1999), Islamic Mysticism Contested: Thirteen Centuries of Controversies and Polemics, Brill, Leiden, p. 357 (fn. 2).

39 A.R. Mustapha \& M.U. Bunza (2014), 'Contemporary Islamic sects and groups in northern Nigeria'. In: A.R. Mustapha, ed., Sects \& Social Disorder: Muslim Identities and Conflict in Northern Nigeria, James Currey, Western Africa Series, p. 56.

40 This was the period when Muslim communities were living as an entity without division. Towns and villages operated under an imam that served as the accepted religious leader. This common identity changed with the emergence of the claims of Ah lul Sunnah. Mustapha provided an interesting quotation from one of the noted scholars of northern Nigeria lamenting this change. He also quoted some of the views of the earlier scholars of Islam (e.g. Abu Hanifa) condemning any reform whose consequences 
getting closer to noted men of God (shuyukhs), for the purposes of prayer for success in business or to excel in one's endeavours. Thus, from the ruling elites and the merchant or business classes down to the commoners, the population sought closeness to the scholarly class. ${ }^{41}$ It was partly this established culture that led the British into implementing their policy of appropriation, containment, and surveillance, a policy detailed by Umar. ${ }^{42}$ So expansive and generic was the policy that it provided an enabling environment that accommodated even scholars and students from neighbouring French colonies. ${ }^{43}$ Yet this was made possible only due to the unceasing surveillance and relentless intelligence reporting by colonial officials. Umar has documented some of these reports by Resident Palmer while he was in Borno and Mr Laing when he was Resident of Zaria Province. Indeed, such a policy was common practice throughout the region. It shows how tactfully the British pocketed a section of the Sufis (Qadiriyya) by accepting them as the official scholars of the ruling class. ${ }^{44}$ Not long afterwards, the scholarly class represented by the two Sufi brotherhoods became entangled in a contest with one another over their positions of authority in Islam. This gave the British confidence that the scholarly class were no longer a threat. This competition among the Sufis, in fact, has made the two brotherhoods less political and more spiritual. It was while under these conditions that more scholars of the Republic of Niger relocated to northern regions of Nigeria to make their living. Mallam Ibrahim Dantasawa was one such scholar; it was also around this time that Shaykh Abubakar Kiota lived in Zaria with the renowned Shaykh Yahuza Zaria, who died in $1958 .{ }^{45}$ Shaykh Abdulrazaq Kuso (Magarya) received most of his scholarly training under Shaykh Tijani Yan Mota and Shaykh Abubakar Atiku Sanka in Kano. ${ }^{46}$ Similarly,

produced more problems than solutions. Refer to the introductory part of A.R. Mustapha, ed., Sects and Social Disorder, op. cit.

41 Ibrahim Tahir (1975), 'Scholars, Sufis, saints and capitalists in Kano', PhD Dissertation, Cambridge University; Auwalu Anwar (1989), 'Struggle for influence and identity: The ulama in Kano, 19371987', MA Dissertation, University of Maiduguri.

42 M.S. Umar, op. cit. La Tijaniyya, p. 330.

43 All the interviews held in Niamey and Maradi testified to this; indeed, it became the common culture of all those who went through Islamic education. A number of the scholars remained in Nigeria until the late 1980s owing to the foreign policy shift in Nigeria during the Shagari regime. Mallam Ibrahim Dan Tasawa remained in Nigeria until during the Maitatsine crisis. Direct contact with the Saudi government and the scholarships to study in Medina have led to a significant shift. The tradition remains only with those within the Tijaniyya circle, who besides scholarship also encouraged visits for the purposes of blessing. The city of Kiota of Shaykh Abubakar is still one of the centres of regular visit, as also is Kuso of Shaykh Abdulrazaq. Indeed, the marriage between Shaykh Abdulrazaq Kuso and Sayyada Ramatoullah Ibrahim Nyass further solidified the relations, owing to her Nigerian parentage on her mother's side. Regular visits of Ramatoullah from Kuso, since the death of Shaykh Abdulrazaq and her relocation back to Nigeria, have become like a festival.

44 M.S. Umar, op. cit. pp. 339-47; see also A.R. Mustapha et al., eds, op. cit.

45 Barhama Sheikh Abubakar Chiota explains that most of the scholars of Niger were taught in Nigeria. Barhama stated that his father, Sheikh Abubakar Chiota, a prominent Tijaniyya sheikh of the whole Republic of Niger, was a student of Sheikh Yahuza Ibn Abdullahi of Zaria.

46 Interview with Malam Tasi'u Danbatta, 2016. 
Nigérien students thronged into northern Nigeria for the same purpose. Liman Shafiú, the son of Liman Ishaq, the present chief imam of the central Maradi mosque, studied in Kano under these conditions. ${ }^{47}$ Most members of the scholarly family interviewed in Maradi (Shaykh Mallam Abba and Shaykh Ibrahim Danjiratawa), in Niamey, and beyond testified that they all studied in Kano, Sokoto, Katsina, Zaria, or Borno during the colonial and postcolonial periods. ${ }^{48}$ Overall, therefore, although new barriers were put in place that clearly separated the territorial lands of Nigeria and the Republic of Niger as distinct political entities, the nature of the French colonial policy and its dislike for mixing religion and governance led many Nigérien scholars and students to move into the northern Nigerian area in search of Islamic knowledge. ${ }^{49}$

Independent Niger did not change much when it came to the government's relationship with Islam and Islamic scholarly culture. Secularization of the polity continued under Hamman Diori, ${ }^{50}$ who adopted an ambivalent posture particularly towards Islam in Niger. Under this policy, no room was afforded to Sharia law to operate, even though customary law was acknowledged in Niger's civil code. The madrasahs (Quranic schools) were kept under state control through the Ministry of Interior, and the state played an active role in training the personnel responsible for running the madrasahs, ensuring thorough surveillance. The upgrade of the system, which rehabilitated Islamic education under the Seyni Kountché regime (1974-1987), was more for political reasons than spiritual. It gave the Republic of Niger international recognition and acceptability by Islamic countries. It was also during this period that Niger began to enjoy financial assistance for the building of mosques and Islamic schools. Niger started to experience so much external influence on its religious life that the government had to take a stand. The Nigérien government was compelled to come with a new form of secularization which instituted firm state control through the only recognized Association Islamique du Niger, ${ }^{51}$ an umbrella association under which all Islamic activities had to be conducted. It was at this point that Saudi Arabia's Islamic influence started to gain ground in the republic. Saudi Arabian-educated technocrats were exported into especially Niger's schools system. New model mosques equipped with

47 Interview with Lliman Shafi'u Liman Ishaq, Maradi, 9 September 2015, chief imam of the Eid prayer mosque, Maradi.

48 Interview with Umar Abdulkadir Hassan, Khalifa of Shaykh Malam Abba, Mallam Banufe, Maradi, 2015.

49 A.R. Mustapha et al., eds, p. 67.

50 Hamman Diori was the first civilian leader in Niger after independence from the French. He was a Muslim and openly proclaimed the fact, attending all the Muslim festivals as well as the spiritual practices. The control was therefore for political gains as well as for religious cooperation. Under his care, the Islamic education system (madrasah) was placed under the Ministry of Interior and not of Education, providing a better opportunity for greater surveillance and ensuring state control and regulation. See ibid. p. 251.

51 F.S.W. Miles, op. cit. p. 253. 
loudspeakers and all sorts of modern gadgets began to be noticed in some select locations in Niger. ${ }^{52}$ This became the dominant culture in the history of Islam from the commencement of the $21^{\text {st }}$ century, especially with the process of democratization in Niger. What remains unique in the case of the Republic of Niger, unlike the case in Nigeria, is that the state stands firm on the noninvolvement of religion in politics. In Nigeria, possibly because of the complex socio-cultural setting and the lack of a shared national identity, government officials unofficially delved into religious activities - for political reasons and, indeed, manipulation. ${ }^{53}$ It was this that introduced the competition for the control and influence of religion in Nigeria, which then expressed itself in doctrinal division, conflict, and insurgency.

\section{Islam and the reformist movements in Nigeria}

The achievement of Independence in Nigeria in 1960 was followed by more serious religious challenges, spearheaded by Shaykh Mahmoud Abu Bakr Gumi. ${ }^{54}$ This marked the beginning of a new reform movement for the revival of Islam after the 1804 Jihad. ${ }^{55}$ This reformist movement inevitably also had effects in

52 One of such examples is the mosque adjacent to Institut de Recherche en Sciences Humaines (IRSH) at Universite Abdou Moumouni, Niamey. The mosque is called Mosquee ibn Hambali (Petit marché) and was built by Himadou Hamani Sirignere, a businessman. He built many such mosques; for example, As Siddik in Kollo, and Imam Malik in Niamey (Wadata). Himadou owns a radio station (Radio Bonferey) and was among the earliest noted supporters of the Ah lul Sunnah followers. Interview with Fatouma Mamouda, Niamey, 6 August 2016.

53 Y.B. Usman (2014), The Manipulation of Religion in Nigeria 1977-1987, Centre for Democratic Development Research and Training, printed by M.O. Press, Kaduna, pp. 5-22.

54 There is still an ongoing debate on who really was behind the Islamic reformist movement of the Jama'atu Izalatul Bid'a wa Iqamatu Sunnah, a development that divided the movement into two, the Jos- and Kaduna-based Izala. Ramzi Ben Amara undertook an interesting study worth referring to for details on the issue. R. Ben Amara (2011), 'The Izala movement in Nigeria: Its split, relationship to Sufis and perception of Shari'a re-implementation', DPhil. Dissertation, Bayreuth International Graduate School of African Studies, BIGSAS, University of Bayreuth, Germany. See also Takaitaccen Tarihin Kafuwar Kungiyar JIBWIS A Jihar Pilato (A short history of the establishment of JIBWIS in Plateau State), Ishaq Dan Jos, Dogon Agogo, Bauchi Road, Jos. For more on Abubakar Gumi, refer to U.A. Yar Tsakuwa (1999), 'The contribution of Sheikh Abubakar Mahmoud Gumi to the understanding of Islamic ideology in Nigeria', BA Dissertation, Department of Islamic Studies, Usman Dan Fodio University, Sokoto; see also his biography, I.A. Tsiga (2001), Sheikh Abubakar Gumi: Where I Stand, Spectrum Books Limited, Ibadan, Nigeria.

55 It is relevant to make some points clear regarding the use of the term 'Ah lul Sunnah'. The adherents of Ah lul Sunnah in Nigeria today share nothing with Shaykh Usman Fodio on matters of reform, because his understanding of the reform of Islam (Sunnah of the Prophet) was built on a Sufi orientation. As explained by M.S. Umar, a Sufi orientation (ethical Sufism) is concerned with preaching; acts of purification and improvement of one's hal (condition) by cultivating praiseworthy attributes in the inner self and cleansing it of blameworthy features; improving one's hal and relations with others; and learning and divine gnosis. On the other hand, the understanding of the present reformers (Ah lul Sunnah, also called Kitab wa Sunnah) is based on the teachings of Muhammad Ibn Abdul Wahhab, who abhorred Sufi doctrines. 
Niger. ${ }^{56}$ Most of the leading religious preachers in Maradi, Niamey, and some other important towns in today's Republic of Niger witnessed these developments while they were students in northern Nigeria. Shaykh Sani Dan'auta studied in Sokoto under the tutorship of a Sufi scholar (Shaykh Mallam Baba) of the Qadiriyya Tariqa. Sokoto was then the centre of the Qadiriyya Sufi order; indeed, Shaykh Usman Fodio himself was a Qadiriyya follower, as also were members of his family. ${ }^{57}$ Shaykh Sani stated that he undertook all his studies in Sokoto under the influence of Qadiriyya Sufi culture, and he returned to Maradi only after completion. Shaykh Mallam Yahaya, leader of Ih Ya'u Sunnah, had the same experience of studying in Nigeria, after which he returned and established his hold in Lakouroussou, a neighbourhood of Niamey. His reformist ideas can be traced to both Nigeria and Habib al Haq of Mali. ${ }^{58}$ Shaykh Malam Suleiman, leader of Kitab wa Sunnah, with headquarters in the Sonni area in Niamey, is a product of a similar experience of Nigerian orientation.

Photo 1 A Karatun Zaure session, in Katsina town, led by Sheikh Mohammad Awwal Zawiyya, the Chief Imam of Katsina Central Mosque, and a Tijaniyyah Tariqa scholar (Photo: Mustapha Gwadabe)

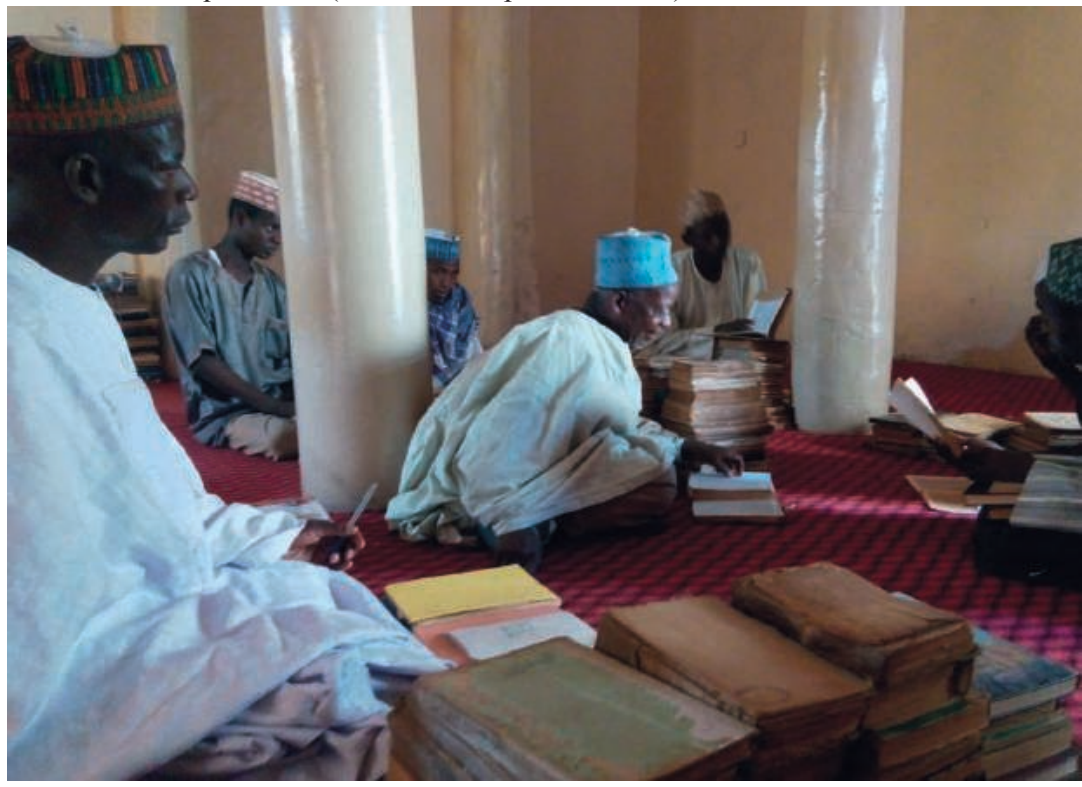

56 A. Brigaglia (2007), 'The Radio Kaduna Tafsir (1978-1992) and the construction of public images of Muslim scholars in the Nigerian media', Journal of Islamic Studies 27: 173-210; M.S. Umar, 'Sufism and its opponents', op. cit.

57 Ibid. p. 358.

58 At his death, Shaykh Sidi Chaibou took over the leadership of the group with its headquarters in Boukoki, a suburb of Niamey. 
Photo 2 Sheikh Sani Dan'auta, Maradi, Republic of Niger. He is a product of Karatun Zaure and still teaches in the same way in his house in Maradi (Photo: Mustapha Gwadabe)

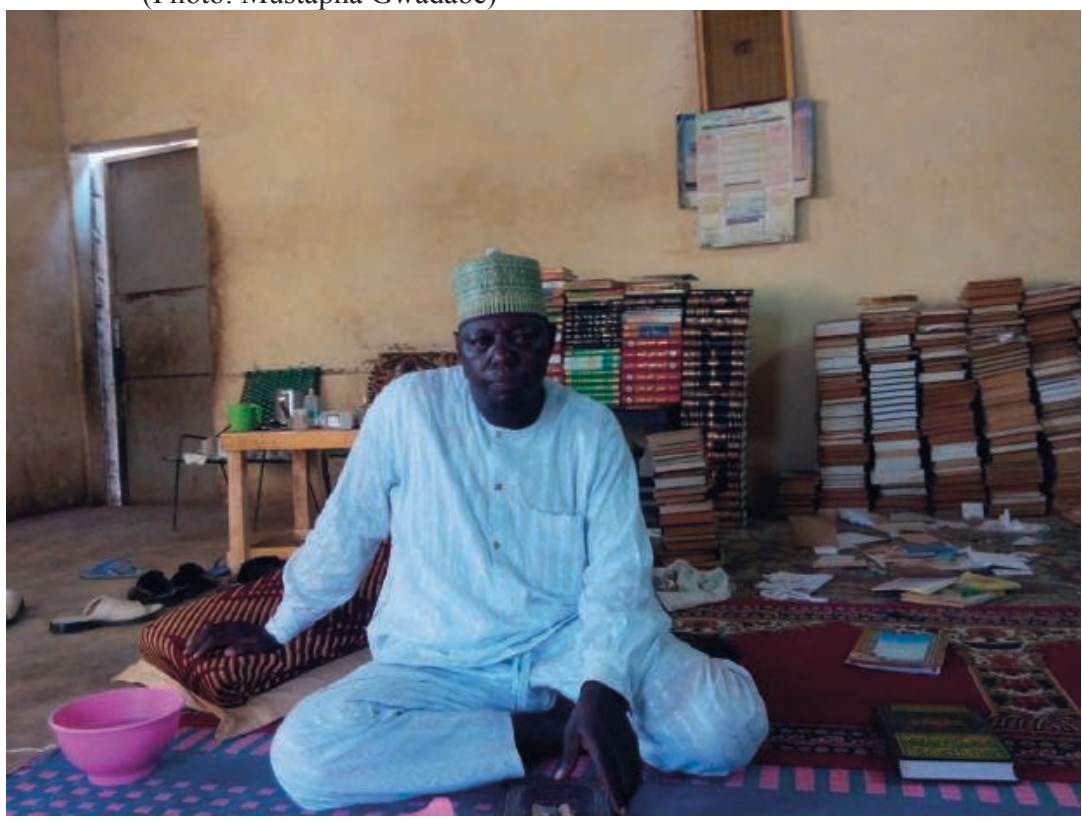

This process of studying in Nigeria has established connections and influences between scholars of Nigeria and Niger, in addition to the fact that historical antecedents have also supported an organic link. As in Nigeria, the Sufi order was the line of thought along which Islam was established in Niger. In his very clear definition of Sufism, Shaykh Fodio identifies it with ihsan, which he defines as every Muslim imitating what the Prophet used to do. This is to worship God as if you see Him; for even if you do not see Him, He sees you. ${ }^{59}$ Though Shaykh Fodio did not discuss mysticism, he recognized it as one of the elements in Sufism reserved for contemplative gnostics. ${ }^{60}$ It is therefore sarcastic to associate the present claimants of Ah lul Sunnah as heirs of Shaykh Usman Fodio. ${ }^{61}$ But that has been the claim. For example, Shaykh Sani Dan Auta, a member of the Ah lul Sunnah preachers in Niger (Maradi), explained that his views against the Sufi order were derived from his 'independent' readings of the works of Shaykh Usman Dan Fodio. ${ }^{62} \mathrm{He}$ detailed his transition more to the regular listening to the tafsir (exegesis) and other commentaries of Shaykh Gumi on the Federal Radio Kaduna.

59 Details of this are found in one of the Prophetic traditions (hadith). See also M.S. Umar, ibid. p. 359.

60 Fodio's detailed position on mysticism is found in his book titled Wa lamma balagtu. M.S. Umar made a concise summary of it in ibid. p. 359.

61 A. Sounaye, 'Heirs of the Sheikh: Izala and its appropriation of Usman Dan Fodio in Niger'.

62 Interview with Shaykh Sani Dan Auta, Maradi, 2005. 
This is the same point that was raised by Shaykh Jafar Mahmoud, one of the noted preachers of the Ah lul Sunnah, who lost his life to gunmen. ${ }^{63}$ Rather than Shaykh Usman Dan Fodio, therefore, it was the radio programme of Gumi that waylaid most of these individuals into reformist Islam. As pointed out by Brigaglia, Shaykh Gumi monopolized the Kaduna Radio station to his advantage owing to his official position as Grand Khadi in the government of the Northern Region, as well as his being adviser on religious affairs to the premier of the then Northern Region. The strategic space he operated from, the Sultan Bello Mosque, was an added advantage to his clout, consisting of government officials of the then Northern Region, politicians, educated elites, and rich merchants. This was in addition to Shaykh Gumi's position as a mediator of funds from the Gulf States, which he used in establishing Islamiyya schools and promoting radical change of the educational system. ${ }^{64}$ In addition to preaching, Shaykh Gumi also wrote a number of books to explain his position, one of which was published in 1972 with the title al Aqida al-Sahiha. Foremost in this book and most of his preaching were attacks on Sufi doctrine in the name of preaching Ah lul Sunnah. He condemned a number of the Sufi rituals as unbelief and demanded excommunication of all those involved. The result of Gumi's outburst created division among scholars and also in mosques, and this affected all other Islamic institutions and relations, including the powers of the traditional rulers for approving the location, construction, and status of mosques. ${ }^{65}$

The anti-Sufi ideas of Gumi can be traced to the training he received while a student at the School for Arabic Studies in Kano, ${ }^{66}$ one of the British educational

$63 \mathrm{Jafar}$, in an interview with Brigaglia, mentioned that his first informal training in the discipline of Ah lul Sunnah came about from his listening to Gumi's radio programmes. Details of the interview are quoted in A. Brigaglia, op. cit. p. 190.

64 Brigaglia's study of Tafsir in Radio Kaduna elaborately discusses all that occurred, including the reasons for Gumi's dominance of the station in op. cit. p. 182. Sheikh Mainasara of Sokoto, but resident in Zaria, who was a critic of Mallam Abu Bakar Gumi, recounted that all his efforts to pay for an advertisement to announce the hosting of Maulud Nabi (celebration of the Prophet's birth) on Federal Radio Kaduna were frustrated in the 1970s by the students of Mallam Abu Bakr Gumi. It was not long before that jinx was broken, possibly around the 1990s, owing to the state policy of austerity measures, which forced all government establishments to source their finances internally.

65 A. Raufu Mustapha et al., eds, Sects and Social Disorder, op. cit., quoted Sheikh Dahiru Bauchi, one of the Tijaniyya sheikhs, lamenting: 'Before the White man came, any town you went to, all you had to do was do ablution and go in to a mosque and say your prayers. You had no need to ask who the Imam was. [...] Gumi has brought his new religion which is called Izala and they say that we are infidel.' Essentially Shaykh Dahiru was stressing the point that, rather than uniting the Muslims, Mallam Abu Bakr Gumi has further balkanised the Muslims into warring factions. See op. cit. p. 65; see also M. Wada \& K.H. Isa (2015), 'The proliferation of Jumu'at mosques in Kano Metropolis: A historical perspective', Paper Presented at International Conference in Honour of Professor Muhammad Sani Zaharaddeen, Department of Islamic Studies and Shari'a, Bayero University, Kano, pp. 8-12.

66 This is not to suggest that training in the school breeds such tendencies, because others did not fall victim. For example, Shaykh Umaru Sanda was his schoolmate, but he never joined such a way of thinking. To understand Shaykh Gumi's life and the possible reasons for his Wahhabiyya Islam, refer to his biography by I.A. Tsiga (2001), Sheikh Abubakar Gumi: Where I Stand, Spectrum Books Limited, Ibadan, Nigeria. 
institutions designed to transform Islamic learning away from the influence of the traditional scholars. ${ }^{67}$ Consequent to the unceasing criticisms of Sufi practices by Shaykh Gumi and his group, an association was established called Jama'atu Izalatul Bid'a wa Iqamatu Sunnah (JIBWIS). Registered during General Ibrahim Badamasi Babangida's regime, the association took upon itself not so much a reform of the religion but a contestation of all Sufi practices and pronouncements. Looking at the scene more critically, the study by Mustapha et al. makes clear that what obtained during this period was a competition for followers, for the prestige of the cleric. ${ }^{68}$ It was a conflict over how to become a good Muslim, not about disbelief, that split the Muslim community; this was not the case with the 1804 Jihad, which was more about reform. The differences so apparently noticed are those of interpretation of the text and the ritual practices, but not of what fundamentally approves or disapproves of one's belief in the religion. Yet Muslims continue to get more divided, with greater sectarian fragmentation and accusations of unbelief (takfir). Thus, efforts at interpretation of texts and the claim for authority in the religion have created diverging views under which sin and unbelief are frequently blurred by sectarian beliefs. In this process, various groups emerged claiming more religious authority and integrity over others, justifying attacks, the perpetuation of violence, and the invasion of individuals' privacy. It was following these developments that Muslim reformists in Nigeria demanded not just reform of the religion but of the Nigerian state, which translated into the introduction of a Sharia legal system in most northern states after the 1999 transition to civil rule. ${ }^{69}$

Sokoto, one of the case studies for this work - and indeed most communities of the Nigerian area - experienced one form of such division or another. While on a larger scale there appeared a proliferation of mosques and Islamic organizations and centres of worship, the development also led to negative consequences. Dominant among these were the struggle for ownership and control of mosques, especially Friday mosques. There also emerged an organized body (Mosque Committee) to look after the mosques, and the yan agaji (aid group). Prior to these developments, only one Friday prayer mosque existed in most major towns, with a recognized imam respected by all members of the community. In some cases, smaller towns did not even have Friday mosques; they had to travel to a nearby town to observe congregational Friday prayer. Prayer (salat) is one of the five pillars of Islam, and it is prescribed to be observed in congregation in a mosque, at specific times, under the leadership of an imam. Most of the mosques in northern Nigeria since the 1804 Jihad were under the control of scholars of Sufi background. The emergence of the reformist Islam represented by the preaching of Shaykh

67 M.S. Umar, op. cit. pp. 372-73.

68 A.R. Mustapha, ed., op. cit. p. 5.

69 Y.B. Usman (2014), The Manipulation of Religion in Nigeria 1977-1987, Centre for Democratic Development Research and Training, Zaria, pp. 5-22, 75-103, 104-136. 
Gumi condemned Sufi Islam and used power and influence to take over most such mosques, starting with the Sultan Bello Mosque in $1962 .{ }^{70}$ Wherever it proved difficult to hijack a mosque, new mosques were built, which led to the phenomenon of the proliferation of mosques within nearly every 100-metre range. So, while from 1809 - when the first Juma'a mosque was built in Sokoto - to 1972 there were only three Jumu'a mosques in the whole city, from 1972 to 2014 the number of Friday mosques increased to a total of 36. The number of non-Friday mosques (khamsa salawat) is uncountable; this is what now obtains in the areas studied in both Nigeria and Niger. ${ }^{71}$ More interesting, however, is that disagreement and conflict over the control of mosques in Sokoto and most other parts of Nigeria were not always peaceful. This development was not peculiar to Nigeria; rather, it was global. ${ }^{72}$ The most interesting development in Sokoto is the case of the Sultan Hassan Dan Mu'azu Juma'a mosque, located in the Runjin Sambo area. ${ }^{73}$ Built in 2001, the mosque was under the control of the Sufi Qadiriyya imam. In addition to the general public, this area is also the residence of staff of the Usman dan Fodio University in Sokoto. Disagreement over the leadership of the mosque came about when the senior imam, Mallam Usman Bakale, died and had to be replaced. Succession periods - due to the death of an imam, for example - were often periods of conflict and disagreement, especially in mosques where there were tendencies to a clear division based mostly on

70 Brigaglia, op. cit. p. 185. The taking over of the Sultan mosque was not automatic; it had to await the death of the imam, his deputy, and the person calling the prayer. I was personally in the mosque when the person calling the prayer made the point that nobody could replace or remove him from performing his function of calling the prayer in the mosque, since it was the Premier of northern Nigeria (Sir Ahmadu Bello) who had appointed him. It was only after his death that the mosque became totally under the control of the Izala. Similar experiences were noted in many other parts of the northern region. Proliferation and contestations for the control of mosques continued in most parts of northern Nigeria. See for detail M. Kyari (2013), The Role of the Mosques in the Socio-Political Development of Maiduguri, Borno State, Ahmadu Bello University Press; I.A. Jawondo (2004), 'The place of the mosque in the history of Ilorin Emirate, 1823-2000', PhD Thesis, Department of History, Usman Danfodio University, Sokoto,

71 In Maradi, Shaykh Sani spoke vehemently on a radio programme to condemn the practice, as not going by the practice of the tenets of the religion, which provided a particular measurement within which mosques should be sited. My interview with him also revealed this point of view.

72 In their study, Wada et al. made reference to the study of West African experience by Cannone, which showed that the rush for control and ownership of mosques was facilitated by the rivalry and competition for the control of the minds of Muslims all over the world. As a result, Saudi Arabian oil wealth was used blindly to gain influence over Sub-Saharan Africa especially, to counteract Iranian influence. It was also with a view to promoting the Saudi brand of Islam (Wahhabiyyah), a development that promoted division among Muslims. For detailed information, refer to M. Wada \& K.H. Isa, 'The proliferation of Jumu'at mosques in Kano Metropolis: A historical perspective', Paper Presented at International Conference in Honour of Professor Muhammad Sani Zaharaddeen, Department of Islamic Studies and Shari'a, Bayero University, Kano

73 Sultan Dan Mu'azu was the $16^{\text {th }}$ Sultan of the Sokoto Caliphate. The mosque was named after him, but the controversy over its leadership can be linked to the interest of the elite members of the community against the Sufi link of the successor. A. Ibn Muhammad (2014), 'The proliferation of Jumu'ah mosques in Sokoto Metropolis and its effects on Muslim unity 1808-2013', MA Dissertation submitted to the Postgraduate School, Usmanu Danfodio University, Sokoto. 
differences of interpretation. In the case of the Sultan Dan Mu'azu mosque, disagreement arose between members of the Mosque Committee (primarily members of the Usman dan Fodio University community) and the ordinary members of the larger community. The basis for the disagreement was ideological differences, but what is commonly reported is that the Sufi imam did not recite the Quran with an Arabic poetic tone and also that his weekly sermon (the Friday qutba) did not respond to contemporary issues. ${ }^{74}$ Since all public mosques are under the control of the traditional institutions of the respective localities, the matter came to the attention of the sultan (Sultan Abubakar Sa'ad), who invited the two groups for reconciliation. Consensus was not reached, and the best they could achieve was to share the time of the use of the mosque on a weekly basis. ${ }^{75}$ In the neighbouring community of Argungun, in Kebbi State in Nigeria, such a disagreement led to the division of a mosque by building a wall inside between the two Muslim groups. ${ }^{76}$

In Katsina, another important town, similar developments occurred, although not quite the same as those in Sokoto. Katsina is a town in northern Nigeria that borders southern Niger, including Maradi, an equally important town in the Niger Republic. Although historically independent states, contacts between these towns on economic and socio-cultural matters are quite strong to date. ${ }^{77}$ These established relationships created the means through which influences were extended between especially Maradi and Katsina in the form of movement and settlement of people.

As narrated by Imam Mallam Auwal (presently the chief imam in Katsina), reformist Islam (Izala or Wahhabi Islam) - as in most parts of northern Nigeria came to Katsina in the late 1970s, when Shaykh Gumi visited the leading scholarly houses and requested their cooperation. Among his requests was one to allow local children to study under his tutorship in Kaduna, which would guarantee them scholarships to travel to Madinah in Saudi Arabia for advanced studies in their fields of endeavour. It was the same strategy he used in most other towns, but he did not succeed in Katsina, in spite of visiting the town over six times. When this strategy did not work to his advantage, a new approach was employed; this was by the unofficial use of official functions to organize a public lecture in the Katsina central mosque, without the knowledge and permission of the chief imam. Rather than informing the chief imam, Shaykh Gumi secured a written authorization from

\footnotetext{
74 Interview with Professor A.M. Gada, Chairman Mosque Committee, Sultan Hassan Dan Mu'azu Mosque, Sokoto, 22 March 2015.

75 Ibid.

76 Interview with Imam Usman Aliyu, Second Imam, Sultan Hassan dan Muázu Mosque, Sokoto. For a similar experience in Kano, refer to M. Wada \& K.H. Isa, 'The proliferation of Jumu'at mosques in Kano Metropolis: A historical perspective', op. cit.

77 Miles, op. cit.
} 
the State House of Kaduna to the Sarkin Katsina, Usman Nagogo. ${ }^{78}$ The logic for sending the letter through the emir was to psychologically weaken the chief imam and other ordinary members of the town so that they would not resist in any way. It was also to coerce the emir into accepting the membership of the new group, which was also the reason why the police were mobilized and deployed to provide protection. The lecture attracted a great number of participants transported from Kaduna. It was therefore a lecture to Kaduna people in Katsina. Efforts to make the lecture a permanent and consistent feature in the mosque failed. Thus, although the effort to take over the mosque did not succeed, it nevertheless introduced the presence of the Wahhabiya ideas into Katsina. Unlike in the case of Sokoto, which was Qadiriyya Sufi (pro-establishment), Katsina town was dominantly Tijaniyya Sufi; indeed, unlike the Qadiriyya, which was consumed and weakened by a feudal autocracy, the Tijaniyya in Katsina remained scholarly and therefore spiritually dynamic.

According to Zaharaddeen, three scholarly families were the pillars that made it difficult for Izala to penetrate Katsina. ${ }^{79}$ They include the families of Shaykh Ahmadu Rufa'i, a leading Tijaniyya scholar connected to the Umarian branch of the brotherhood. He was also the chief imam of Katsina from 1962 until his death in 1977. He enjoyed a large following across Katsina emirate and Daura, which comprised the aristocracy, business class, civil servants, and the merchant class. His death in 1977 created a serious vacuum, especially among the Westerneducated elements in the civil service class resident in Kaduna. The scholarly family of Shaykh Ja'afar was next in line; its Shaykh Ja'afar died in 1984. He was noted for his greater influence on most of the Tijaniyya leadership in Katsina. He had very extensive Islamic knowledge - for example, concerning the Quran and its exegesis, the hadith, jurisprudence, and Sufism; he was also noted and respected by the community for his good virtues, patience, sympathy, respect for people, punctuality in appointments, and reflecting true Islamic practices in his dealings with members of the general public. ${ }^{80}$ Shaykh Abba Abu Rafindadi was the next in line; he died in 1994. Like Shaykh Ahmad Rufa'i, he was of the Umarian Tijaniyya, and also a sharif (a descendant of a grandchild of the Prophet). Though the three families still have heirs engaged in scholarly activities, the powers and

78 Being a leading figure in the community of Muslims in northern Nigeria, Abubakar Gumi influenced the writing of the letter and sent it directly to the emir. This is one of the ways in which Gumi used his position to influence decisions in favour of his group. When approached by the chief imam for explanation, the only statement from the emir was that the chief imam and his people should stay away or support the activity. This was when Katsina was under Kaduna State, and indeed Kaduna was the main headquarters of the Izala.

79 Z. Suleiman (2015), 'A history of the Tijaniyyah Brotherhood in Katsina, 1906-2009', MA History, Bayero University, Kano; see also A.I. Yandaki (1990), 'A history of the Izala movement in northern Nigeria up to 1989', Unpublished MA (History) Dissertation, UDUS.

80 Z. Suleiman, op. cit. 
scholarly authority the parents wielded during their times could not be sustained by the younger generation. ${ }^{81}$ It was at this time that Izala found the opportunity to establish its influence in Katsina. It was also at this time that Katsina State was created from Kaduna State, a development that forced Katsina civil servants to relocate back home. ${ }^{82}$ The predominance of Katsina people in the civil service of Kaduna was due to the advantage of Western education which Katsina people had, as a result of the establishment of Katsina College in colonial days. This singular factor produced people open to new and modern ideas. Thus, most of the Katsina indigenes who settled as civil servants in Kaduna returned to Katsina as members of the Izala group. The advantage of their position as civil servants gave Izala the upper hand in regard to financial and moral support, through which they took over mosques and acquired new land for the construction of many mosques all over Katsina town. While this lessened the contestations and conflict over ownership and control of mosques in Katsina, it presented another dimension of the problem. This was in the form of the proliferation of mosques and contests for worshippers, especially in the residential areas. Like the Pentecostals, the various imams had to be creative either by eloquence in recitation of the Quran or in preaching to attract worshippers. The fitting out of mosques with modern facilities is another means, making the general environment very noisy during times of prayer. The worst are the traffic problems along most of the access roads, including on highways. This is in addition to the hijacking of road traffic control by members of aid groups (yan agaji), who have no form of training. The prevalence of aid groups as paramilitary groups is not only a security risk but is institutionalizing parallel state structures. This also represents a weakening of the Nigerian state and provides space for people to take the law into their own hands.

\section{Democratic transition, the state, and Islamic reformism in the Republic of Niger}

It is clear from the foregoing account that scholarly relations between Nigeria and Niger have a very long history, such that various kinds of influence between the

81 Although Sheikh Ja'far's son Sheikh Muhammad al-Hadi was appointed as the successor and new muqaddam of the movement, there were small-scale dissociations, especially among elderly followers who considered the new muqaddam too young to lead the movement. Sheikh Hadi, as he was popularly called, was indeed knowledgeable in the eyes of the followers of fayda in Katsina, for he studied Islamic sciences such as Quran, hadith, Sirah, and Sufism at the zawiya of Sheikh Ibrahim in Senegal, and he had wide connections to important Tijaniyya centres in Africa. Nonetheless, his age as the muqaddam became a serious issue for many of the followers of the fayda community. This factor had the effect of providing the basis for the establishment of other Tijaniyya enclaves or zawiyas in Katsina openly independent of the main zawiya of fayda under Sheikh Hadi.

82 Kaduna is the seat or headquarters of Shaykh Gumi's group of Izala. The political status of Kaduna as regional headquarters as well as the capital of Kaduna State, which Katsina was part of in 1969-1987, gave Izala the upper hand. It was also because of the official position of Gumi as the Grand Mufti. 
countries cannot be isolated or doubted. This is confirmed by Boukar's study of the history of the evolution, development, and spread of Izala in the Republic of Niger. ${ }^{83}$ It was also the outcome of interviews with noted scholars of Maradi and Niamey, and indeed is very clear in the writings of Professors Maïkorema and Sounaye. ${ }^{84}$ In his study, Boukar commented on the influence of Nigérien deportees from Saudi Arabia (ethnic Kurtey from western Niger) who, ignoring the secular stand of the Nigérien government, began to preach a return to orthodox Islam (Wahhabism) and criticized the teachings of Sufi (Qadiriyya and Tijaniyya) scholars. Boukar further pointed out that the influence of these deportees was restricted to the rural areas, especially around the settlements along the border between Niger and Mali. Indeed, he stressed the point that the spread of this influence to other parts of the Republic of Niger can be attributed to the longestablished relations between Nigerian and Nigérien scholars and students. ${ }^{85}$

The Islamic reformist movement started active participation in the affairs of governance in Niger from the 1990s, following the establishment of a stable democratic structure. Then, less than ten years later, Nigeria also experienced a stable democracy, which saw the introduction of Sharia Islamic law in Zamfara State, a state neighbouring the Republic of Niger. According to unproven speculation, state funds were misused in financing unbudgeted religious activities for political purposes which had an enormous impact on the larger Muslim communities of the region. Like the developments in most Islamic communities of the $21^{\text {st }}$ century Sahel, the Republic of Niger also experienced divisions and debates between the emerging rival organizations. This and the general instability that characterized the country's first steps into democracy strongly influenced the decision-making bodies of the various governments and challenged the state authority. Thus, successive regimes defined themselves by the way and manner in

83 D. Elh. Boukar, 'La Dynamique du Mouvment Izala dans le quarti Wadata (4e'me arrondissement de Niamey)', Faculté des Lettres et Sciences Humaines, Département de Sociologie, Universite Abdou Moumouni de Niamey, 2012-2013; see also the chapter by Zakari Maïkoréma (2007), 'La naissance et le development du movement Izala au Niger'. In: Jean-Louis Triaud, ed., Islam: Societies et politique en Afrique subsaharianne, Les exemples du Sénégal, du Niger et du Nigeria.

84 Zakari Maïkoréma (2009), L’islam au Niger de 1960 au début des années 2000, Harmattan.

85 More specifically, it was the product of a very long contact with the teachings of Shaykh Abubakar Gumi and a retired soldier named Shaykh Ismail Idris, from Jos. The influence penetrated into Niger, through the neighbouring towns of Maradi, Zinder, Diffa, and Birnin N'Konni, into the urban and commercial towns frequently visited by preachers, educated elites, and the business class. In Maradi, the activities were led by Rabe Dan Tchadoua, but that was at the time when the Nigérien government was intolerant of the activities of religious groups. This point was also echoed in strong terms by Professor Maïkoréma during an interview at his IRSH office, Niamey. In his chapter, « La naissance et le development du movement Izala au Niger », (in J.-L. Triaud, ed., Islam: Societies et politique en Afrique subsaharianne, Les exemples du Sénégal, du Niger et du Nigeria, 2007) Maïkorema is also categorical about the influence of Nigeria in the spread of the Wahhabi (Izala) Islam in most parts of the neighbouring towns and indeed in the hinterland of Niger. He also mentioned the influence of Sudan, Pakistan, and Saudi Arabia. 
which they unduly entertained Islamic associations. ${ }^{86}$ Much more than in the past, the religious exponent - more precisely, the Islamist exponent - became a political force to reckon with. What differentiated the Nigérien from the Nigerian experience was the lack of direct state involvement. The main actors in the case of the Republic of Niger were young aspiring scholars with little or no influence on the state. If anything, they benefitted only from a lax state that permitted direct external support (financial and scholarly / educational) from Middle Eastern countries - particularly Saudi Arabia - for the Nigérien scholarly community.

Among the issues of concern in Niger were also the intra-religious squabbles between the respective divisions within Islam; but the most vivid challenge that fired all Muslim groups, as reported by Abdoulaye Sounaye, focused on the promotion of Islamic values. ${ }^{87}$ This was in respect not only of the dominance of Islam as a major religion in Niger, but the history of the long separation of the state and religious institutions in the country. Consistently, the state promoted a secular identity on matters of governance, similar to the trend during the colonial era and against the growing interests of the reformist Islamic culture that came to dominate the public space in Niger, especially in the more urbanized areas of Niamey and Maradi. The outcome, which was supported by the termination of Niger's oneparty system of political arrangements of the past, was the emergence of various pressure groups, including private media. ${ }^{88}$

The support provided by the Islamic countries of Saudi Arabia, Iran, and Sudan to funding and scholarships made a considerable difference to, and indeed shaped, the intra-religious contestations in Niger. As noted earlier, the secular nature of the state confined religion to the private lives of people, such that no organizational activities were permitted. This state of affairs, unlike that in Nigeria, has defined the limits of religious activities, so much so that it was never an issue of debate. Although mosques, as places of worship, have long been in existence in Niger, the culture of holding up religion as a mirror to explain social life was not permitted by the state. Thus, in the 1990s, when the democratic transition occurred and new religious groups emerged, as well as the culture of the politicization of religion, mosques remained a place of worship. Indeed, most of the mosques were directly owned by scholars (or associations of scholars) and not by the state or community, and as such the issue of taking over a mosque or conflict over a mosque was not pronounced. The influx of funds due to the contest between Saudi Arabia's brand of Islam and that of Iran, supported by the democratic trend in Niger, created a

86 Interview with Zakari Maïkoréma, IRSH, Niamey, 2015.

87 A. Sounaye, 'Recognizing religion in democratisation processes in Sub-Saharan Africa: A case from Niger', p. 50. Sounaye is Professor of Philosophy, Religion and Development Studies at Abdou Moumini University of Niamey, Niger.

88 Sounaye noted the formation of more than 50 Islamic associations around this period. See ibid. p. 56 for details. 
new scene entirely. Rather than taking over older mosques, new and well-furnished mosques were built. In Maradi, Shaykh Sani Dan Auta revealed that based on such support, his mosque and house were built. Indeed, he subsists on such support especially when he goes out for the purposes of $d a$ 'wa (preaching, lit. 'issuing an invitation or summons') to rural villages. Shaykh Falalu, a middle-aged scholar of the Ih'ya U'Sunnah in Maradi, was also building a new mosque and a school at the time of this field research in 2015, supposedly supported by such funding. ${ }^{89}$ The centre for Islamic learning popularly called 'Moufidah' in Maradi is also run by such a fund. Moufidah is composed of a mosque, and an Islamic school that trains young children in primary and secondary education to qualify them for tertiary institutions. Indeed, the dominant culture in the Republic of Niger today is that scholars look for resources to build mosques and schools. In some cases, wealthy individuals contribute to these initiatives of providing financial support, granting land, and sometimes building classrooms. Alhaji Rabé dan Tchadoua is very well noted for this effort. He is inclined to Wahhabi Islam and therefore gives the mosques he builds to the Izala group. His impact is noticeable even in Niamey; indeed, like Ahaji Ahmadu Chanchangi in Nigeria, wherever mosques are built in Niger the name of Dan Tchadoua is associated with them. According to one informant, Dan Tchadoua does not discriminate when it comes to building mosques; this is unlike the case of Chanchangi in northern Nigeria, who finances only the building of Izala mosques and other related activities. Among other individuals mentioned as performing the same function is Alhaji Mamman Jangile, whose impact is very pronounced in Maradi. ${ }^{90}$ Democratization has therefore transformed religious activities by liberalizing the political environment, such that without the backing of the state, an individual or association can relate directly to the outside world to access funds for religious activities, or for scholarships to further his studies abroad. ${ }^{91}$ The implications of this are obvious, and it is part of the challenge faced by the Nigérien people and society at this time of religious insurgency.

\section{Conclusion}

Nigeria and the Republic of Niger share much in common, making it predictable that what obtains in Nigeria can also be found in Niger. This is seen by following

89 The source of funding for the mosque was not made clear, but general discussion with some staff and the leader clearly showed strong links with the proponents of the 'anti-innovation' groups (Ah lul Sunnah), and more specifically with the Moufidah Islamic group. Indeed, most of the staff and close associates at Sheikh Falalu School were graduates of Moufidah Secondary School in Maradi. Discussion with Sheikh Falalu, 12 September 2015, at his residence in Maradi.

90 It is speculated that most of these influential individuals act as fronts for some of these donor countries to avoid suspicion and also for diplomatic reasons.

91 A. Sounaye, 'Recognising', op. cit. 
the history of scholarship and learning between and across the borders of the two countries. By implication, therefore, a Boko Haram-type militancy, just like other scholarly relationships, is likely to be found among the communities of the Republic of Niger. ${ }^{92}$ Notwithstanding this analogy, the historical reality that produced French colonial policy in the Republic of Niger - especially the dislike for mixing politics, governance, and religion - has made a difference. The French influence led to the establishment of secularism to define and represent the nature, form, and character of the state in Niger, and this approach was adopted by the succeeding administrations after Independence. Although democratization of the Nigérien polity has relaxed the secular nature of the society, the long-established culture, the dynamic political organization, and the communality of socio-culture of the people have made it difficult for Islamist groups to instigate a serious challenge to the state. Such militant preaching as obtains in Nigeria is never permitted in Niger. Furthermore, elements of national unity and feelings of nationhood persist more in Niger than in Nigeria - and whatever the challenge, the forces that unite the people have so far always prevailed. Indeed, the general culture and contemporary development which made available resources to build new mosques have created a better solution and have made contestations over places of worship and learning irrelevant. What remains relevant, however, is that the manner in which Islam is taught in schools - due to the influence of the Wahhabi tradition - breeds tendencies to radicalism and militancy.

\section{Acknowledgements}

I thank my research assistants Dr Murtala Rufa'i in Sokoto, Hon. Sani Musa Arkaf, and Mallam Aminu Zubairu Liman in Katsina, and Dr Aliyu Maradi and Mallam Noura in Maradi. Professor Seyni Moumouni was my contact in Niamey. I thank Professor Zakari Maïkorema for granting me interviews in addition to making available a number of his publications. Mallam Ango Saley translated all my French documents; I thank him greatly. I benefitted considerably from the scholars I interviewed in Katsina, Maradi, Sokoto, and Niamey.

\section{References}

ABUBAKAR, A. NUHU-KAKO (1989), 'A geographical analysis of trans-border trade between Nigeria and Niger border settlements', In: A.I. Asiwaju \& B. Barkindo, eds, The Nigeria-Niger Trans-border Cooperation. Research and Documentation Centre, National Boundary Commission, Malthouse Press.

92 Group interview in Niamey with Dr Mahadi El Hadji Maazou, Dr Salao Alhassane, and Dr Ayouba Laouali, (IRSH) Jamiátu Attadamun, Université Privée Franco-Arab, Niamey, 2015. 
ADAM, J. (2005), 'The role of JIBWIS in the development of Arabic and Islamic culture in Jos'. BA Dissertation, Department of Arabic Studies, University of Jos.

AHMED, M.S. (1989), 'Nigeria-Niger relations: Historical and cultural perspective', In: A.I. Asiwaju \& B. Barkindo, eds, The Nigeria-Niger Trans-Border Cooperation. Research and Documentation Centre, National Boundary Commission, Malthouse Press.

Al-Malah, H.Y. (2008), The Governmental System of the Prophet Muhammad: A Comparative Study in Constitutional Law. Dar al Kitob al-Ilmiyat, Beruit.

AlKali, N. et al., eds, (1993), Islam in Africa: Proceedings of the Islam in Africa Conference. Ibadan: Spectrum Books Limited.

ASIWAJU, A.I. (2001), West African Transformation: Comparative Impacts of French and British Colonialism. Lagos: Malthouse Press Limited.

AsIWAJU, A.I. \& B. BARKINDO (1989), The Nigeria-Niger Trans-Border Cooperation. Research and Documentation Centre, National Boundary Commission, Malthouse Press.

Awogbade, M.O. \& U.A. HusSAIN (1989), 'The Nigeria-Niger trans-border cooperation: The trans-humance/nomadic pastoralist factor'. In: A.I. Asiwaju \& B. Barkindo, eds, The NigeriaNiger Trans-Border Cooperation. Research and Documentation Centre, National Boundary Commission, Malthouse Press.

BAFFA, A.U. et al., eds, (2012), 'Muslim educational reform activities in Nigeria'. A joint publication of IIIT Nigeria and Faculty of Education, Bayero University, Kano, Benchmark Publishers Limited, Kano, Nigeria.

BAIER, S. (1974), 'African merchants in the colonial period: A history of commerce in Damagaran (Central Niger) 1880-1960'. PhD Thesis, University of Wisconsin.

BARKINDO, B.M. (1989), 'Relations between Kano and Republic of Niger's region of Asbin (Air) Maradi and Damagaran (Zinder): Perspectives for evolving a more viable trans-border policy between Nigeria and Niger'. In: A.I. Asiwaju \& B. Barkindo, eds, The Nigeria-Niger TransBorder Cooperation. Research and Documentation Centre, National Boundary Commission, Malthouse Press.

Bello, U. (trans.) (2003), Letter to Muslims by Caliph Muhammad Bello. Iqra'a Publishing House, Kaduna, Nigeria.

Ben Amara, R. (2011), 'The Izala movement in Nigeria: Its split, relationship to Sufis, and perception of Shari'a re-implementation'. PhD Thesis, BIGSAS, University of Bayreth, Germany.

BUgAJE, U.M. (1997), 'Some reflections on the development of Islamic learning in Katsina (1300-1800 AD)'. In: I.A. Tsiga \& A.U. Adamu, eds, Islam and the History of Learning in Katsina. Ibadan: Spectrum Books.

DiGGI, B.B. (2008), 'A comparative study of the role of Sufism in the Sokoto Jihad and the Iranian Revolution'. PhD research proposal submitted to the Graduate School, UDUS.

DigGi, B.B. (2010), 'Sufism in Hausa Land and the formation of the Sokoto Caliphate'. Postgraduate seminar paper presented to the Department of History, UDUS.

Dumber, R. DAmagaran (1970), 'Zinder, Niger 1812-1906: The history of a Central Sudanic kingdom'. PhD Thesis, University of California.

FAGGE, M.D.A. (1997), 'Literary life in the intellectual tradition of the ulama in Kano since 1804'. Unpublished PhD (History) Thesis, BUK.

GADA, A.M. (2010), 'A short history of early Islamic scholarship in Hausaland'. Department of Islamic Studies, Usman Danfodio University, Sokoto, Nadabo Pring Production, Kaduna.

GLEW, R.S. (2001), 'A discourse-centered approach toward understanding Muslim identities in Zinder, Niger', in Islam et societies au sud du Sahara. Foundation Mission des Sciences de l'homme, Paris. 
GraZIANO, K. \& GHISLAINE LydOn, eds, (2011), The Trans-Saharan Book Trade: Manuscript Culture, Arabic Literacy and Intellectual History in Muslim Africa. Brill, Leiden, Boston.

GREGOIRE, E. (1993), 'Islam and the identity of merchants in Maradi (Niger)'. In: L. Brenner, ed. Muslim Identity and Social Change in Sub-Saharan Africa. London, Hurst.

GuRAMA, MuHAmMad NuHU (2000), 'Leadership trusts in an Islamic organisation: A case study of the Jama'at Izala Al-Bid'ah Wa Iqamat Al-Sunnah (JIBWIS)'. MA Thesis, Department of Islamic Studies, University of Jos.

Gwandu, A.A. et al., eds, (1995), Islam and Contemporary Politics: Proceedings on Islam and the Political Challenges of Modern Times. Sokoto: Usman Danfodio University Press.

HiLl, J.N.C. (2010), Sufism in Northern Nigeria: Force for Counter-Radicalization? Carlisle: USAWC.

HINJARI, W.L. (1989), 'The impact of an international boundary on the political, social and economic relations of border countries: A case study of Kano, Katsina states of Nigeria and Niger Republic'. In: A.I. Asiwaju \& B. Barkindo, eds, The Nigeria-Niger Trans-Border Cooperation. Research and Documentation Centre, National Boundary Commission, Malthouse Press.

HunwiCK, J. (1989), 'Borders, boundaries and the concept of State in the Islamic tradition'. In: A.I. Asiwaju \& B. Barkindo, eds, The Nigeria-Niger Trans-Border Cooperation. Research and Documentation Centre, National Boundary Commission, Malthouse Press.

INGAWA, T.L. (1997), 'The period c. $16^{\text {th }}$ to $18^{\text {th }}$ century in the history of learning in Katsina'. In: I.A. Tsiga \& A.U. Adamu, eds, Islam and the History of Learning in Katsina. Ibadan: Spectrum Books.

IsA, A. ABBA (1989), 'The Niger factor in the implementation of Kano's policy on Almajirai'. In: A.I. Asiwaju \& B. Barkindo, eds, The Nigeria-Niger Trans-Border Cooperation. Research and Documentation Centre, National Boundary Commission, Malthouse Press.

ISA, L.A. (2009), 'Emergence and evolution of unguwanni (wards) in Birnin Katsina c. 14951949'. Unpublished PhD (History) Thesis, BUK.

ISHAQ, DAN Jos (2012), Takaitaccen Tarihin Kafuwar Kungiyar (JIBWIS) A Jihar Pilato. Dogon Agogo, Bauchi Road, Jos.

Kane, O. (2003), Muslim Modernity in Post-Colonial Nigeria: A Study of the Society for the Removal of Innovation and the Reinstatement of Tradition. Leiden; Boston: Brill.

KANI, A.M. (1997), 'The place of Katsina in the intellectual history of Bilad Al-Sudan up to 1800'. In: I.A. Tsiga \& A.U. Adamu, eds, Islam and the History of Learning in Katsina. Ibadan: Spectrum Books.

KAssiM, A. (1992), 'The evolution and development of Jibia as a border town to 1980'. MA Dissertation, Bayero University, Kano.

KAURA, J.M. (2004), 'Relevance of Qadiriyya Sufism in the Jihad and its moderative effect on the leadership of the Sokoto caliphate'. Paper presented at the Conference of Ulama organized to commemorate the 200 years of Sokoto Caliphate held at the Attahiru Dalhatu Bafarawa Institute of Qur'anic and General Studies, Sokoto, July 2004.

Koвo, O. (2009), The Development of Wahhabi Reforms in Ghana and Burkina Faso, 19601990: Elective Affinities between Western-Educated Muslims and Islamic Scholars. Department of History, Ohio State University, USA.

KuKaH, M.H. (1993), Religion, Power, and Politics in Northern Nigeria. Ibadan: Spectrum Books.

LAST, M. (2012), 'From dissent to dissidence: The genesis and development of reformist Islamic groups in northern Nigeria'. Paper presented at the Interfaith Relations in Northern Nigeria Conference, Abuja. 
LAVERS, J.E. (1997), 'Katsina and the outside world: Adventures in the historiography of Birnin and Kasar Katsina'. In: I.A. Tsiga \& A.U. Adamu, eds, Islam and the History of Learning in Katsina. Ibadan: Spectrum Books.

LOIMEIER, R. (1998), 'Islamic reform and political change: The example of Abubakar Gumi and the Yan Izala Movemenmt in northern Nigeria'. In: D. Westerland \& E. Evers Rosander, eds, African Islam and Islam in Africa: Encounters between Sufis and Islamists. London: Hurst.

LoImeIER, R. (1997), Islamic Reform and Political Change in Northern Nigeria. Illinois: Northwestern University Press.

LugGA, S.A. (2006), Dikko Dynasty. Katsina: Lugga Press.

LugGa, S.A. (2007), Sheikh Haruna, Wazirin Katsina (1857-1937). Katsina: Lugga Press.

Mamdani, M. (2004), Contemporary Political Terror: Its Origins in the Late Cold War. Department of Political Science, Ahmadu Bello University, Zaria.

MASQMELLIER, A. (2009), Women and Islamic Revival in West African Town. Indiana University Press, Bloomington and Indiana Polis.

MAUdudi, S.A. (1963), A Short History of the Revivalist Movement in Islam. Lahore: Islamic Publications.

MiLES, W.F.S. (1989), 'The reality and promise of partition in Hausaland'. In: A.I. Asiwaju \& B. Barkindo, eds, The Nigeria-Niger Trans-Border Cooperation. Research and Documentation Centre, National Boundary Commission, Malthouse Press.

MiLES, W.F.S. (1994), Hausaland Divided: Colonialism and Independence in Nigeria and Niger. The Wilder House Series in Politics, History and Culture, Cornell University Press, Ithaca and London.

Muhammed-BABA, T.A. (1989), 'Pastoral Fulbe transhumance in the context of the NigeriaNiger border: Implication for trans-national cooperation'. In: A.I. Asiwaju \& B. Barkindo, eds, The Nigeria-Niger Trans-Border Cooperation. Research and Documentation Centre, National Boundary Commission, Malthouse Press.

MukTAR, A. (1989), 'The role of traditional institutions and cultural values in fostering transborder cooperation: The case of Nigeria-Niger border'. In: A.I. Asiwaju \& B. Barkindo, eds, The Nigeria-Niger Trans-Border Cooperation. Research and Documentation Centre, National Boundary Commission, Malthouse Press.

MusTAPHA, M.I. (1989), 'The Nigeria-Niger boundary 1890-1906: Evolution and implication on trans-border socio-economic activities'. In: A.I. Asiwaju \& B. Barkindo, eds, The NigeriaNiger Trans-Border Cooperation. Research and Documentation Centre, National Boundary Commission, Malthouse Press, Lagos.

NANIYA, T.M. (2000), 'Arab settlers in Sub-Saharan Africa: A survey of their influence on some central Sudanese states', Kano Studies, New Series 1(1).

ODIHI, J.O. (1989), 'Nigeria-Niger trans-border crossing during environmental crisis: Towards planning for disaster mitigation'. In: A.I. Asiwaju \& B. Barkindo, eds, The Nigeria-Niger Trans-Border Cooperation. Research and Documentation Centre, National Boundary Commission, Malthouse Press, Lagos.

ONOJA, L.A. (1989), 'Problems of local administration and the imperative of border cooperation: The experience of Katsina State'. In: A.I. Asiwaju \& B. Barkindo, eds, The Nigeria-Niger Trans-Border Cooperation. Malthouse Press, Lagos.

PAden, J.N. (1973), Religion and Political Culture in Kano. Berkeley: University of California Press.

PAden, J.N. (2008), Faith and Politics in Nigeria: Nigeria as a Pivotal State in the Muslim World. Washington DC: United State Institute of Peace Press. 
PÉRoUSe DE Montclos, M.A. (2014), 'Boko Haram and politics: From insurgency to terrorism', in M.A. Pérouse de Montclos, ed., Boko Haram: Islamism, Politics, Security, and the State in Nigeria., Ibadan-Leiden: IFRA-African Studies Centre.

PHILLIPS, J.E. (1982/85), 'The Islamisation of Kano before Jihad', Kano Studies (New Series) 2(3).

QUADRI, Y.A. (1983), 'An examination of the emergence of the Tijaniyyah in Nigeria', NATAIS 2(2), (December).

RAJI, R.A. (1997), 'Katsina as the gateway of the earliest Muslim scholars and learning in Nigeria: The case study of Madh literature'. In: I.A. Tsiga \& A.U. Adamu, eds, Islam and the History of Learning in Katsina. Ibadan: Spectrum Books.

SALIHU LAWAL (2009), 'Islamic scholarship in pre-Jihad period: Katsina and the contribution of Dan Marna Shaykh Muhammad Ibn al Sabbagh', Danmarna, International Journal of Islamic Culture and Heritage 1(1), Umaru Musa Yar'adua University, Katsina.

SANI, A.B. (2012), Trade Diplomacy, Banking and Finance in the Trans-Saharan Trade: An Interpretation of Ahmad Abu al-Gaith's Ledger, a Trade Consul in Katsina, 1824-1870. Kaduna: Pyla-Mak Publishers.

SaUlawA, A.M. (1989), 'Drought, animal husbandry impact and the state in Katsina-Maradi boundary division of Nigeria and Niger republics c. 1972-1983: A historical analysis of drought phenomenon and the need for stronger trans-border cooperation'. In: I.A. Asiwaju \& B. Barkindo, eds, The NigeriaNiger Trans-Border Cooperation. Lagos: Malt-House Press.

SHEA, P.J. (1989), 'Reflections on the economic interdependence of regions of Kano and Niger'. In: A.I. Asiwaju \& B. Barkindo, eds, The Nigeria-Niger Trans-Border Cooperation. Research and Documentation Centre, National Boundary Commission, Malthouse Press.

SOUNAYE, A. (2007), 'Instrumentalizing the Qur'an in Niger's public life', Journal for Islamic Studies 27(1): 211-39.

SOUNAYE, A. (2009), 'Izala au Niger: Une alternative de communaiti religiense', in L. Fourchard, O. Goerg \& M. Gomez-Perez, eds, Les lieux de sociabilité urbaine dans la longue durée en Afrique. Paris: L'Harmattan.

SOUNAYE, A. (2012a), 'Heirs of the Sheikh: Izala and its appropriation of Usman Dan Fodio in Niger', Cahiers d'Etudes Africaines (206/7): 427-47.

SOUNAYE, A. (2012b), 'Recognizing religion in democratization processes in Sub-Saharan Africa: A case from Niger', Ciência \& Trópico 36(1): 45-72.

SOUNAYE, A. (2013), 'Alarama is all at once: Preacher, media "savvy", and religious entrepreneur in Niamey', Journal of African Cultural Studies 25(1): 88-102.

SOUNAYE, A. (2014), 'Mobile Sunnah: Islam, small media and community in Niger', Social Compass 61(1): 21-29.

Thurston, A. (2009), 'Interactions between northern Nigeria and the Arab world in the twentieth century'. Unpublished MA (Arab Studies) Thesis, Georgetown University, Washington DC.

Trimingham, J.S. (1962), A History of Islam in West Africa. London: Oxford University Press.

TSIGA, I.A. (1992), Sheikh Abubakar Gumi: Where I Stand. Ibadan: Spectrum Books.

UBAH, C.N. (2001), Islam in African History. Kaduna: Baraka Press.

UMAR, M.S. (1983), 'Islamic revivalism today: The example of the Jama'atu Izalatul Bid'ah Wa Iqamatis Sunnah'. BA Thesis, University of Jos.

UMAR, M.S. (1988), 'Sufism and anti-Sufism in Nigeria'. Unpublished MA (Islamic Studies) Thesis, BUK. Umar, M.S. (1993), 'Changing Islamic identities in Nigeria 1960-1980: From Sufism to anti-Sufism'. In: Louis Brenner, ed., Muslim Identity and Social Change in SubSaharan Africa. London: Hurst. 
UMAR, M.S. (2006), Islam and Colonialism: Intellectual Responses of Muslims of Northern Nigeria to British Colonial Rule. Leiden: Brill.

USMAN, Y.B. (1997), 'The state of learning and the state of society: From the Jihad to SAP'. In: I.A. Tsiga \& A.U. Adamu, eds, Islam and the History of Learning in Katsina. Ibadan: Spectrum Books.

Wright, Z. et. al. (2011), The Removal of Confusion Concerning the Flood of the Saintly Seal Ahmad Al-Tijani: A Translation of Kashif al-Ilbas an Fayda al-Khatam Abi al-Abbas by Shaykh al-Islam Al-Hajj Ibrahim b. Abd. Allah Niasse. Egypt: Al-Imam Shaykh Tijani Ali Cisse.

YANDAKI, A.I. (1990), 'A history of the Izalah movement in northern Nigeria up to 1989'. Unpublished MA (History) Dissertation, UDUS.

YAR-TSAKUWA, U.A. (1999), 'The contributions of Sheikh Mahmoud Abubakar Gumi to the understanding of Islamic ideology in Nigeria'. BA Thesis, Department of Islamic Studies, Usman Danfodio University, Sokoto. 


\title{
Islamic legal radicalism: The cases of Katsina and Maradi
}

\author{
Abdourahmane Idrissa
}

The Hausa saying, 'Nijar da Najeriya duka su ke', ${ }^{1}$ perfectly illustrates the case of the Maradi Region (Niger) and Katsina State (Nigeria), which truly seem to be two sides of the same coin. The two capitals of these districts are located within a onehour drive of each other, and their stories share an inseparable link. The political entity that is Maradi was founded in the early 1820 s by a pact between the former ruling dynasty of Katsina, then in exile in the Sultanate of Damagaram, and the animist populations of the region. The latter, resisting the Katsina emirate's attempts to incorporate them into the territory of Sokoto, eliminated the Fulani emissary Mani Acha and arranged the assumption of power in Maradi by Dan Kassawa, head of Katsina's old royal dynasty. Dan Kassawa assumed the title 'King of Katsina' (Sarkin Katsina) as opposed to 'Emir of Katsina', which was used by the Fulani chief who had been installed by Sokoto in his family's former capital. At the time, Maradi was a 'war camp' (sansanin yaki) from which Katsina was to be re-conquered. However, by the late $19^{\text {th }}$ century, the kings of Katsina in Maradi had, in reality, given up on that project. In 2010, their official title became 'Sultan of North Katsina', acknowledging the scission of the old Katsina, which had been confirmed by the modern border between Niger and Nigeria.

The populations of Maradi and Katsina are composed predominantly of the Katsinawa, a sub-group of the Hausa. The physical, historical, and cultural proximity of the two cities is reinforced by the fact that they are part of a 'trade corridor' known as the 'KKM corridor' (Kano-Katsina-Maradi), which forms the backbone of Maradi's trading prosperity, especially after the severe recession of the 1990s. This detail is quite important. The young generation of the 'Alhazai of

\footnotetext{
1 'Niger and Nigeria are one and the same' - or, more precisely perhaps, 'Niger and northern Nigeria', given that Nigerians in the south seem to hardly be aware of the existence of Niger.
} 
Maradi' - the rich merchants and entrepreneurs of the city ${ }^{2}$ - has almost entirely converted to Izala Islam, which propagates the legal radicalism discussed in this chapter. Given the predominance of this movement among the elites of Kano and Katsina, and the fact that the other social categories of Maradi's population often become 'Izalaized' through contact with merchants, it is quite clear that the ties between Nigeria (Katsina and Kano) and the Maradi trading community have an influence on the spread of the movement.

Map 3 Geographical distribution of Idrissa's fieldworks

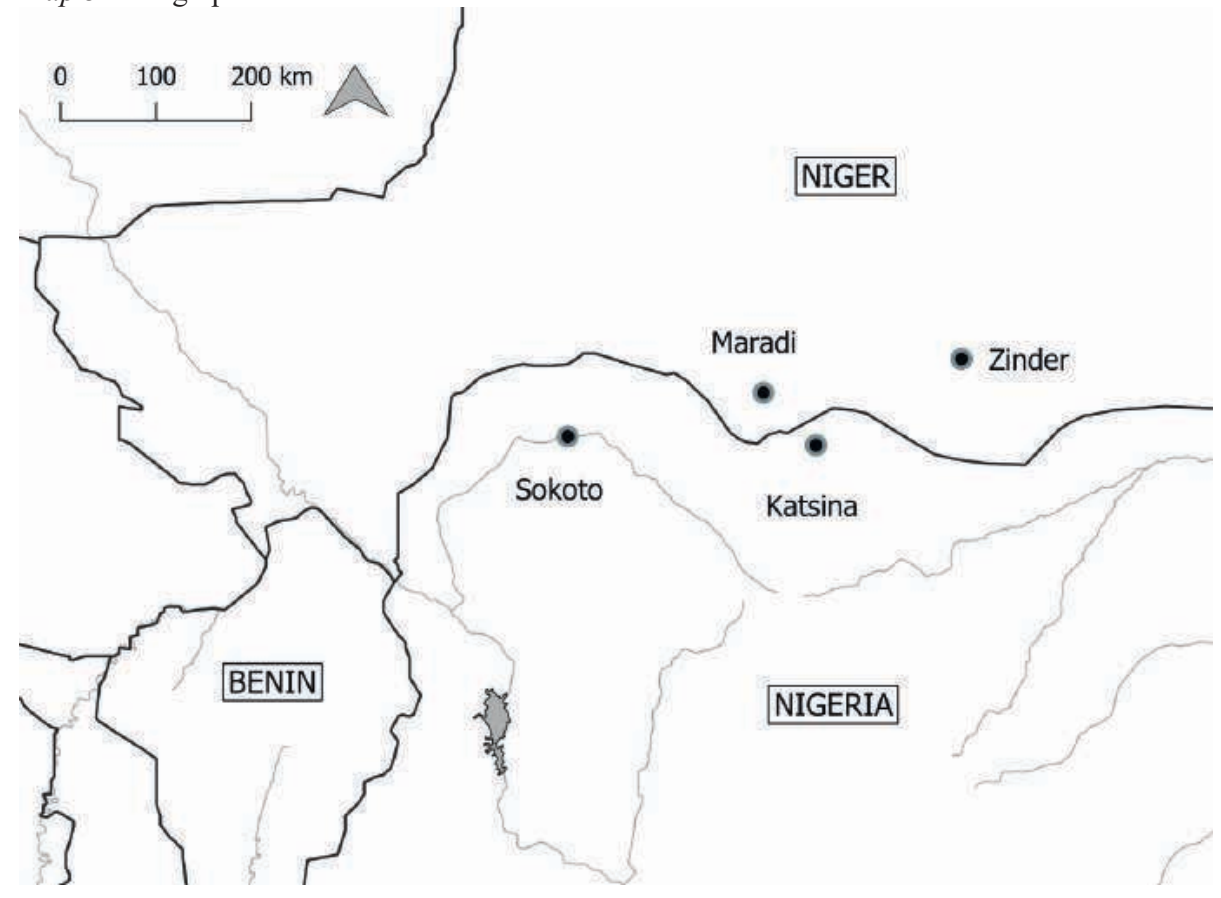

The religious sociology of Maradi is very similar to that of Katsina, especially when considering the jahars $^{3}$ of which the two cities are the administrative capitals. One finds the same predominance of the Tijaniyya in the countryside and of the Izala in urban areas; the presence of animist communities, called arnawa in Niger and maguzawa in Nigeria; and the presence of Christian minorities, native

2 In Les Alhazai de Maradi: histoire d'un groupe de riches marchands sahéliens (Paris: Orstom, 1986), Emmanuel Grégoire studied the first two generations of this community of capitalist merchants.

3 This Hausa word, which means 'administrative district', is used in that language in reference to both Nigérien regions and Nigerian states - which can cause some confusion, especially on the Nigerian side, as the two administrative entities are very different. 
to the region and well integrated into its social fabric. Although the government of Katsina Emirate has gotten rid of its old Hausa socio-political structure, while this is still largely in place in Maradi, the proximity of the two 'traditional chiefdoms' tends to create numerous similarities between them, expressed for example through their attachment to the Islamic nature of their respective regimes.

In summary, despite the scission that was imposed by the Sokoto jihad and then entrenched by British and French colonialism, the evolution of Maradi and Katsina in the $20^{\text {th }}$ century presents remarkable continuities in terms of religion and tradition. However, since 2000, the institutional landscape of the rule of law in Katsina has been progressing in ways that do not seem to be even on the horizon in Maradi. The same dynamic factors behind this rift can also be found in Niger, yet their effects there are different and are generally much milder than in Katsina. While the latter lives in the age of the Sharia Implementation, Maradi remains a city where religious agitation does not seem to compromise the secularism of public institutions. Of course, in Maradi, just as in the rest of Niger, secularism in public places has changed considerably - or deteriorated, if considered from the perspective of a French-style republican secularism. But comparing it with Katsina helps put things into perspective and shows that Maradi still remains a place of secularism, which is actually a source of great frustration for the Izala leaders of the city.

In this chapter, some of the origins and characteristics of the differences between Katsina and Maradi are analysed and a reflection is centred on two instances of Islamic radicalism: 'legal radicalism' and 'political radicalism'. Without being insurrectional, the first type of radicalism has proved to be more subversive than political radicalism has, as discussed later. In Nigeria, Islamic radicalism has been legal / subversive in the states of the north-central and northwest regions (including Katsina) and political / insurrectional in north-eastern states. In Niger, Islamic radicalism failed to become legal and therefore was never subversive, despite some 'negative' or symbolic victories obtained during the first 15 years of political democratization (1991-2006). During that time, Niger was undeniably the site of a kind of Islamic political radicalism, but one that failed to reach the levels of mobilization and ideological penetration required to transform the national political landscape. Since then, Islamic activism in Niger has been expressed mainly through preaching, the spread of Arab-Islamic education, and sporadic riots, all of which have long since become routine in northern Nigeria.

Thus, the point in comparing Maradi and Katsina is to answer two separate yet related questions: Why, given the proximity between the two jahars, has legal radicalism been so successful in Katsina but not in Maradi? And does the fact that Maradi seems to be simply 'behind' Katsina mean that the region is going through a phase of initial political radicalization that could set it on a more similar path to 
that of the capital of 'South Katsina'? Without trying to provide definitive answers to these two questions, particularly to the second one, we will see that it is still possible to acquire a fairly accurate picture of the current situation.

\section{Katsina: A waning utopia}

The Sharia Implementation was promulgated by the government of Katsina in 2000. The previous year, Governor Ahmad Sani Yerima had launched the process with great fanfare in Zamfara, the state's capital, during a ceremony that was reportedly attended by a crowd of over two million Muslims, who had come from all the northern states and other parts of Nigeria. The groundswell spread throughout the region. The stated objective of the Sharia Implementation was the enforcement of 'full Sharia', ${ }^{4}$ which on a pragmatic level quickly translated into the application of criminal laws designed to eradicate 'crime and sin'. Before the process was even finalized and initiated in Katsina, many courts in local governments, known as 'area courts', began to implement Sharia criminal laws against sexual debauchery (zina), theft, and physical injury, while injunctions intended to shut down drinking establishments and abolish prostitution proliferated. In 2000, under popular pressure, the government created a Sharia Commission that reused, for the most part, the agenda developed in Zamfara. A law for the adoption of a Sharia-based penal code was passed in a hurry and went into effect the following year. Yet, as early as August 2000, 'area courts' had been transformed into 'Sharia courts' and had started to adjudicate on both civil and criminal cases using Maliki legal tradition as the sole point of reference. Even before the state had passed laws or taken any measures, some popular festive practices, such as songs, dances, and drums, began to disappear not only from large urban areas, but also from small towns located in the periphery of state local governments. ${ }^{5}$ The Izala theological movement, which promoted Sharia Implementation, was particularly active and well-organized in Katsina, thanks to the dynamism of its leaders, especially Malam Yahaya Yakubu, who deserves further attention.

Yahaya's journey is not unlike that of Muhammad Yusuf, the founder of Boko Haram. Having been educated exclusively in Arab-Islamic religious institutions first in his father's tsangaya (domestic religious school) and then at the Arabic

4 This expression refers to the adoption of the penal provisions of the Sharia in addition to the civil provisions already in force.

5 For further details, see Gunnar J. Weimann (2010), Islamic Criminal Law in Northern Nigeria: Politics, Religion, Judicial Practice, Amsterdam University Press, in particular pp. 29-32; William S. Miles (2003), 'Shari'a as de-Africanization: Evidence from Hausaland', Africa Today 50(1): 51-75; and P. Ostien, eds, (2007), Sharia Implementation in Northern Nigeria, 1999-2006: A Sourcebook, Volumes I-V, Ibadan, Nigeria: Spectrum Books Limited. 
Islamic College of Katsina - Yahaya honed his preaching skills in Maradi in the mid-1970s as he was just coming out of adolescence - a detail that is reminiscent of the many family ties between northern (Niger) and southern (Nigeria) Katsinawas. After earning a degree from Bayero University Kano and teaching at the Katsina Teacher's College, he resigned in 1983 to devote himself entirely to anti-government radical preaching. An admirer of the Iranian Revolution, he joined the entourage of radical Shi'ite leader Malam Ibrahim al-Zakzaky, becoming the spokesperson of his organization, the 'Islamic Movement', in Katsina in 1985 . The group formed by Yahaya consisted mainly of lower-class young people from the city of Katsina and from semi-rural villages in the state. As their leader, he fought the city's security forces during riots in April 1991. There were no deaths, which reinforced Yahaya's prestige among the radical Muslims of Katsina. ${ }^{6}$ The informal influence of his movement across the entire state of Katsina enabled him to put pressure on the government so that it would support the Sharia Implementation starting in 2000.

An independent committee was created in 2000 under the leadership of Yahaya and other Izala figures - Yahaya had joined the Izala movement at the end of the 1990s (as had Mohammed Yusuf) - whose goal was to monitor the government's commitment to support the legal aspect of the Sharia Implementation. Over the years, the committee's criticism tended to demonstrate that the government of Katsina resorted to delaying tactics in order to push back the Sharia Implementation: by delaying the appointment of Sharia court judges; favouring secular criminal courts ('magistrate courts') for the treatment of cases involving Muslims; or consistently refusing to endorse and compensate the hisbah, the religious militia in charge of arresting Sharia violators, in a context where the federal police were not encouraged to take on that work. ${ }^{7}$ Criticism came not only from Izala circles; there is active support for Sharia Implementation in Katsina from executives and intellectuals of the city - perhaps more so than in Kano, where the intellectual milieu is more diverse. The vision of these intellectuals is laid out both in official documents, such as reports of the Sharia Commission, and in intellectual works such as Malam Abubakar Yusuf's essay, Shari'a and Contemporary Issues, presented in Katsina in March 2010. While the Izala focus primarily on criminal and missionary Sharia, these intellectuals are trying to get the government to promote economic and social Sharia, but they are even less successful than their comrades-in-arms. From the perspective of its proponents, after 15 years of implementation, the Sharia Implementation programme in

6 See Toyin Fayola (1998), Violence in Nigeria: The Crisis of Religious Politics and Secular Ideologies, University of Rochester Press, in particular pp. 194-221.

7 See Weekly Trust, 26 July 2003, 'Sharia Implementation in Katsina: The journey so far', an article written by Lawal Ibrahim; and Vanguard Daily, 1 March 2001, 'Committee accuses Katsina Government of sabotaging Sharia', an article published anonymously. 
Katsina is a failure. The local judicial system has been reformed, yet the tactics used by the government make it possible for the implementation of Sharia to adapt to the norms of the (non-religious) rule of law upon which the Nigerian legal system is based. ${ }^{8}$ A kind of 'normalization' of Sharia took place, which was the opposite of what was intended by a project meant to be radical. A survey conducted by the research and statistics institute Afrobarometers eight years after the launch of Sharia Implementation shows that support for Sharia has significantly increased among the population, both in states that implement Sharia and in those that do not. ${ }^{9}$ Even among the Christian population, support or approval has gone up ten points - from 13 to $23 \%$. Interviews conducted in Katsina confirm these statistics for all the local populations, Muslims and Christians alike, but also reveal that support has increased because the project has changed over time. In other words, what is supported or approved is not so much an unadulterated and hard-line Sharia, which would translate into sentences such as stoning, dismemberment, or retaliation, but instead the normalization of Sharia - that is, the moderation of its sentences with an implied 'repugnancy' clause and, at the same time, the rapid nature of its procedures. However, that is not what proponents of the reform originally meant by 'Sharia Implementation'.

In order to understand the significance of this 'failure' of the Sharia Implementation in Katsina, one should examine both the political context of its launch in the state and the limitations intrinsic to the nature of the project. A new generation of rather young politicians (in their late thirties and forties) - often described, at the time, as 'pragmatists', as men determined to 'get things done' and to be 'efficient' - came to the fore across the country with Nigeria's return to a civilian democracy in 1999. The most striking example was that of the former governor of Lagos, Babatunde Fashola. Unlike the governors of military regimes, ${ }^{10}$ who were army officers appointed by their superiors, the governors of the democratic era got to their positions thanks to the support of political parties that had a national base. In the north, some of the young governors became convinced that Islamizing the government through the implementation of Sharia was an effective way to 'get things done' and to be 'efficient', counting on Islam's ability to mobilize a largely Muslim population. The best illustration of this, of course, is Ahmad Sani Yerima, who became Zamfara State's first elected governor at the age of 39 and who initiated the process of Sharia Implementation. Old-school politicians - who were more business-oriented than they were idealists or

8 The acquittal in 2003 of Amina Lawal, the woman sentenced to stoning for adultery, was a cause célèbre at that time and one of the first signs of normalization.

9 'Popular Perception of Shari’a Law in Nigeria', Afrobarometer Briefing Paper n`58, February 2009. http://afrobarometer.org/sites/default/files/publications/Briefing\%20paper/AfrobriefNo58.pdf

10 Between 1983 and 1999, no fewer than five military leaders consecutively ran the Nigerian state: generals Buhari, Babangida, Shonekan, Abacha, and Abubakar. 
pragmatists - were much less interested in this undertaking, which, in their view, would be difficult and uncertain.

This was the case in Katsina, then governed by Umaru Musa Yar'Adua - who would later be President of the Federal State. Yar'Adua was a man of the old political guard, a member of an aristocratic Fulani family of the emirate that held the honorary title of mutawalli (steward of the Emirate treasury), which he bore when his father died. Unlike Sani Yerima, who entered the political arena thanks to the restoration of democracy in 1999, Yar'Adua began his political career nearly two decades earlier, under the Second Republic. He was part of the political group formed by his older brother, Shehu Musa Yar'Adua, under the name of People's Front, a club of business-minded politicians which later merged with the Social Democratic Party of Nigeria (SDP), one of the two parties that the Babangida military regime had authorized in 1989 in preparation for an impending return to democracy. The People's Front was also the formal expression of the infamous 'Kaduna Mafia' network, supposedly extinct, which was formed by politicians and political patrons - mainly from the north - who owed their power to the support given by Olusegun Obasanjo when he ruled the country between 1976 and 1979. Obasanjo ratified the decisions of the 1979 constitutional commission rejecting the creation of a federal Sharia Appeal Court, and he was able to impose this decision in the north largely thanks to the support of the 'Kaduna Mafia'. ${ }^{11}$ It was obvious that, being a member of this political movement, Yar'Adua was not an ideal governor for a dynamic and sincere support of the Sharia Implementation. Many of the analysts interviewed in Katsina actually stressed his reluctance, while some even insinuated that he may have sabotaged the operation. According to Judge Danladi Abubakar, Yar'Adua was faced with a contradictory situation: given the immense popularity of the Sharia Implementation at the time, he had to support it in order to be re-elected - or at least appear to be supporting it and certainly not oppose it; at the same time, however, Yar'Adua was part of a great national party, the People's Democratic Party (PDP), and in particular of a faction within the party that bound him to politicians from the south and forced him to take into account the opinion of Christians on the issue. ${ }^{12} \mathrm{He}$ had to please both camps. While the Sharia Implementation was successfully initiated in Katsina - and relatively early on - it was only weakly supported by the government.

But despite the frustrations and virulent criticism that his attitude elicited, Yar'Adua managed to get re-elected in 2003, which was probably due in large part to his family's powerful presence in Katsina's society. This re-election dealt an additional blow to the Sharia Implementation in the state. A simple comparison of the evolution of Katsina with that of its neighbouring state, Kano, reveals just that.

\footnotetext{
11 The significance of these events is discussed in the third section of this chapter.

12 Interview in Katsina on 7 January 2015.
} 
In 1999, the Governor of Kano, Rabiu Kwankwaso, came out of the same mould as Yar'Adua, in the sense that he was also a former member of the People's Front and of the SDP, which formed an alliance with the PDP, and he had the same reluctant behaviour towards the Sharia Implementation. In the 2003 elections, he was severely defeated by Malam Ibrahim Shekarau, a gubernatorial candidate with a pro-Sharia agenda. Shekarau went on to support missionary and criminal Sharia with the full power of the state - including officially recognizing the hisbah; establishing a 'Societal Reorientation Directorate' in charge of reforming the morals of the Kanawas; and strengthening the Censorship Board in order to rein in Kannywood, the Hausa film industry whose capital is Kano. To local supporters of Sharia Implementation, Katsina paled in comparison with those achievements.

That being said, even in Kano the Sharia Implementation was widely perceived as a failure when compared with the initial project. When Shekarau ran for governor in 2015 - after the four-year hiatus, mandated by the constitution, between two consecutive terms and a third term - he was defeated by Kwankwaso. Analysing the situation in Katsina sheds light on the non-circumstantial causes of a failure that transcended state borders. To begin with, the fact that the Sharia Implementation in Katsina ended up being limited to its punitive aspects was seen as deeply problematic by a certain class of actors, whom we will call executives and Islamo-nationalist intellectuals (see further below). Paradoxically, one of the Islamo-nationalist intellectuals who fought the most for the Sharia Implementation to succeed in that state was Danladi Abubakar, a senior judge on the Katsina State High Court, which falls under what he himself refers to as 'conventional law' (i.e. secular law). He is not the only one, in fact, since many 'conventional' lawyers, who were met during fieldwork, support the process and have lent a hand so that the codification of Sharia would follow the forms and standards of modern legal codes - forms and standards that they alone master. However, these intellectuals are less interested in criminal Sharia, the substance of which reflects the Izala's literalist orientations, than they are in economic and social Sharia; they are angry and appalled at the fact that the former draws all the attention - and fears - of the outside world and even of a part of the country's Muslim population.

The Sharia penal code replicates the form of modern codes of secular law, including the very decision to define Sharia within the constraints of a written legal code. But its substance strives to literally match the injunctions and prescriptions of the Quran and the Sunnah, which, from the perspective of the Islamo-nationalist intellectuals, creates a contradiction - though they do not say so openly. Although its editors insist on its literal adherence to the legal tradition of the Sunnah and the hadiths, the Sharia penal code also inherits its rigidity from the doctrinal and ideological sensitivity of the Izala and of Islamo-nationalist intellectuals. One can 
easily imagine, as it has been done elsewhere in the past, ${ }^{13}$ that since the codification created a form of positive law - with Sharia as its Grundnorm ${ }^{14}$ - it could be adapted to the cultural, political, and economic aspects of northern Nigeria's modern society. Such an adaptation would have been necessary had the concern been to get the law to handle the practical issues, old and new, of that society. However, the goal of Sharia Implementation proponents was focused more on an ideal and less on its technical aspects: it consisted in reinventing the perfect Islamic society the way it may have existed at the time of Prophet Mohammed, or at least the time of the Sultanate of Sokoto, and whose tradition has supposedly been destroyed or perverted by colonialism. The substance of the criminal code is thus determined by the fact that it must not only set in stone the literal word of Prophetic traditions, but also purge the north of the deleterious effects of colonial rule, which the proponents of implementation believe has survived through the secularism of Nigeria's federal state. ${ }^{15}$ It must also reflect a particular aversion to expressions of local cultures, which the Izala theology likens to 'paganism' and which Islamo-nationalist intellectuals perceive as un-Islamic. This also includes cultural practices that had often been accepted by the currents of a so-called traditional Islam (adinin galgajiya), including the Tijaniyya. It is therefore not surprising to see that, besides expected literalist sanctions against the use of alcohol or sexual acts between adults of the same sex, festive practices such as 'praise singing and drumming' could constitute an offence. This would outlaw the art of griots, but the definition of this crime means that the penalty attached to it could also apply to certain Sufi rituals, for example. ${ }^{16}$ Any gathering of persons

13 See Ruud Peeters (2005), 'The enforcement of God's Law: The Shari'ah in the present world of Islam'. In: Philip Ostien, Jamila M. Nasir et al., Comparative Perspectives on Shari'ah in Nigeria, Ibadan, Spectrum Books, pp. 107-34. Peeters places the Nigerian process in the category of 're-Islamization Shari'a', characterized by its ideological rigidity and the fact that it is imposed to force Muslims to become 'good Muslims'.

14 The 'fundamental norm' which, in Hans Kelsen's Pure Theory of Law, is the first historical expression of a body of law, and which must be obeyed as such, directly or through positive law.

15 Thus, the explanatory memorandum of the Katsina Sharia Commission, written by Islamo-nationalist intellectuals, states: 'The system of government imposed by the colonialist, particularly in the former Sokoto Caliphate, which was hitherto governed by Shari'a, has eroded the Islamic way of life. The systems of governments after independence were all off-shoots of the imposed system[,] and successive administrations, military or civilian have caused neglect and abuse in governance [such] that the society became socially and morally corrupt.' See also a text written in Hausa by Yusuf Adamu from Bayero University, Kano, 'Shari'ar Muslunci da Turawan Mulkin Mallaka a Daular Sakkwato' ('Islamic Shari'a and Western colonization in the State [Caliphate] of Sokoto'), presented at a conference in Kano that took place on 25-26 June 2001 and available on kanoonline

(http://www.kanoonline.com/publications/pr_articles_shariah_a_nijeriya.html). Adamu defines the independence of Nigeria as dominated by 'Sekulanci' (secularism) as opposed to 'Islamic Shari'a'.

16 Early on, these rituals had incurred the wrath of Abubakar Gumi, the man who had inspired legal radicalism in northern Nigeria. In Where I Stand, Gumi sarcastically described his first contact with the Oriental Sufi rites, during a stop in Libya: 'In Tripoli ... I had my first experience with full-fledged Sufi worship, with drums and ecstasy which I could not quite associate with the dignity and poise usually desired of someone saying his prayers.' (Where I Stand, Ibadan, Owerri, Kaduna, Lagos: Spectrum Books Ltd, p. 66). 
of the same sex involving dance and music is also illegal under the Sharia penal code, which would actually amount to banning most of the northern Nigerian film industry, which constantly stages such gatherings ${ }^{17}$.

Therefore, the Sharia codes inevitably create criminals whose distinctive characteristic is mainly their material poverty or the vulnerability of their social status. They establish categories of crimes and offences that make it easier to incriminate vulnerable people (women, for example) or the members of the working classes, because their (mis)behaviour is more exposed and more easily monitored by a 'local police' such as the hisbah, for example. Despite the absence of statistical data, the interviewees - who were in favour of Sharia, as it were - all emphasized the fact that crime has gone down in Katsina since the Sharia Implementation was first launched. This piece of information is credible insofar as 'crime' is understood mostly as petty crime, prostitution, and observable moral disorder - all of which primarily concern people from disadvantaged backgrounds and which are even easier to fight through street policing and 'speedy' justice.

Given the Promethean ambition of these codes, social inequality in the way that crime and sin are punished is a troubling outcome for Islamo-nationalist intellectuals. Judge Danladi Abubakar underlines the implicit contradiction which now exists between criminal Sharia and the Sharia Implementation project. The rigorous discipline these codes impose on individuals can only be accepted in its transformative - and not only repressive - logic if the integrity of the rulers is equally rigorous and if it is paired with a project of economic justice and effective public charity. If the project is losing momentum, it is because it has failed to take into account the need for a popular legitimization of criminal Sharia. It is clear that given the massive enthusiasm shown when the process was initiated, proponents of the Sharia Implementation may have thought that its legitimacy was a sure thing. But after 15 years of effort, the problems seem more complex than initially, and the results are clearly limited and ambiguous.

Directly targeting the contradiction between criminal Sharia and the Sharia Implementation in a public lecture given in March 2010, Judge Danladi Abubakar wished to underline, in this context, that Sharia is not limited to a set of legal codes. Sharia is essentially, he said, 'a coalition of spiritual, moral, socio-economic and legal norms blended and interwoven together'. For an effective implementation of Sharia, all the components mentioned must be brought to work concurrently. But in order for the spiritual and moral aspect to have an effect on individuals and society, he insisted, the government had to provide 'honest, sincere, just, and transparent leadership'. It had to create

17 See Carmen McCain (2013), 'Nollywood, Kannywood and a decade of Hausa film censorship in Nigeria', in Daniel Biltereyst \& Roel Winkel Vande, eds, Silencing Cinema: Film Censorship around the World, London, Palgrave MacMillan, pp. 223-40. 
an economic environment that would oppose monopolistic tendencies and the exploitation of vulnerable people, all the while putting in place a system of social assistance to the needy under the leadership of people who, once again, at all levels of authority, would be truly responsible, honest, fair, and transparent. ${ }^{18}$

The judge insisted heavily on the rigour of the leaders, because the establishment of Sharia institutions inevitably created opportunities for corruption, so much so that the level of corruption in the state may have increased accordingly. At the beginning of the Sharia Implementation process, those called 'secularist Muslims' by their 'pro-Sharia' opponents had already predicted this development, ${ }^{19}$ but this observation is also made today by serious Islamonationalist intellectuals such as Judge Danladi Abubakar in Katsina. Unfortunately, we were unable to collect examples of such misconduct during the survey, for reasons one might guess. That being said, an almost caricatural illustration of the contradictions that the Sharia Implementation can engender is found in what took place in the neighbouring state of Kano in August 2010, a few months after the conference of the Katsina judge. This was not corruption per se, at least not in the financial sense, but the details of this contradiction appeared in all their grotesque obviousness.

The origins of the case go back to 2007, when a sex scandal broke out in Kano after a private video of a sexual nature, involving an actress from Kannywood, made the rounds in the city, notably on cell phones via Bluetooth. In response to what was a private incident, Governor Shekarau appointed a former commander of the hisbah, Malam Abubakar Rabo Abdulkarim, to the head of the state's Censors Board, whose assignment was to 'moralize' Kannywood. The new Director of the Censors Board began his work by multiplying arrests, fines, and bans on the dissemination of cinematographic works, while also making countless speeches on state media about morality in Islam, in particular vis-à-vis women and young girls. Three years later, in August 2010, a police patrol caught Abdulkarim in his car in a compromising position with a minor. He tried to escape, was caught after being hit by a motorcyclist, and was taken to the station where his identity was discovered. Abdulkarim was released on bail and immediately left the country under the pretext of making the small pilgrimage of umrah - but mainly to let things 'blow over', which would obviously not be a viable solution for a man from

18 Danladi Abubakar, 'The role of citizens in the promotion of Shari'a', a paper presented for the launch of Malam Abubakar Yusuf's Shari'a and Contemporary Issues, Katsina, 28 March 2010.

19 See for example, Abubakar Siddique Mohammed, Sa'idu Hassan Adamu \& Alkasum Abba (2000), The Living Conditions of the Talakawa and the Shari'ah in Contemporary Nigeria, published by the Centre for Democratic Development, Research and Training, Kano. The book was vehemently condemned by Islamo-nationalist intellectual Ibrahim Ado Kurawa in an article entitled 'Muslim secularists rationalisations against Shari'ah', published by the National Council for the Defence and Propagation of Shari'ah, primarily because of the idea that the authors would be read in the West rather than for its arguments. 
the working class. Despite Governor Shekarau's promises to open an investigation, Abdulkarim was not charged and he peacefully resumed his duties upon his return from Saudi Arabia.

Such incidents have contributed to people's disappointment in the Sharia Implementation and show that, with its radical ambition, the project contains a strong element of utopian thinking, which places it at odds not only with the parameters of Nigerian political life and the social and cultural complexity of the north, but also with the motives and characters of the people who implement it.

\section{Maradi: The weight of provincialism}

Just like 'states' in Nigeria, 'regions' in Niger are both political and administrative entities. However, regions are much more integrated into the central government than states are into the federal state. Visible structures are similar. In Nigeria, the state replicates the federal presidential model within its territorial unit; in Niger, the region is a parliamentary structure - which is similar to the base model of the Nigerian states - with an elected Regional Council headed by the President of the Regional Council, a position which is more similar to that of a prime minister than to that of a president of the Republic.

The Regional Council and city councils make up the base of local politics. Like the governors in Nigeria, the President of the Regional Council in Niger is always de facto a 'native son'. The same is true for regional and city councillors. This kind of political structure allows for the expression of local sub-patriotisms, which can bring about virtually systemic divergences among the political entities that constitute the central state, such as those that the Sharia Implementation elicited in Nigeria. However, it would actually be impossible for this kind of development to take place in Niger. Unlike states in Nigeria, regions in Niger do not share the sovereignty of the central state; they simply implement it at the local level. Regions and city councils have resources to carry out regional public policies in areas 'of local and regional interest', but the main policies are implemented in collaboration with the central state, meaning that local and regional public policies are just local adaptations of policies that have been decided at the central level. With its 'decentralized state services' formula, the national administration places itself at the service of regions and cities, yet the careers of civil servants and the administrations' operating budget depend on centralized decisions. At the head of the Nigérien regions, there are also governors, but these are representatives appointed by the central executive power, not locally elected officials.

The most important outcome of such an institutional makeup, as far as the subject at hand is concerned, is that the Nigérien judiciary has no real local expression. While Katsina judges, prosecutors, and lawyers are usually Katsina 
natives appointed by the government of Katsina, those in Maradi are not necessarily Maradi natives and are appointed by the central government. In both countries, the judicial system operates on a kind of dualism, mixing or juxtaposing secular (or conventional) law and customary (or Islamized) law. In Nigeria, this dualism is generally a form of parallelism. In Katsina, before the Sharia Implementation was initiated, the judicial system comprised, at the first-instance level, English law courts ('magistrate courts' for criminal law, 'district courts' for civil law) and 'native law' courts, which handled customs, Sharia, and criminal law of English origin for small crimes and offences (in 'area courts'). This dualism has been strengthened by the Sharia Implementation, since 'Sharia courts', which replaced the area courts, now handle both civil and criminal cases. In Niger, this dualism is a form of hierarchy: traditional leaders have first-instance jurisdiction over minor civil disputes or petty crime at the local level, on which they adjudicate following Islamized customs, while people with immediately higher rank apply Romano-Germanic law. This hierarchy also applies to family law cases, which are heard by secular judges who are assisted by assessors specialized in Islamized customs. This institutional landscape reflects Niger's colonial past, when conventional law was considered to be 'the right of the citizen' (superior), while customs were seen as 'the right of the subject' (subaltern). While these legal values may have ceased to exist, the effects that they generated live on in a very different context, in particular through the fact that customs (including Islamized customs), although used as a legal accessory, are not actually part of the law. ${ }^{20}$

In this context, it is not surprising that there has been no emergence of a legal radicalism similar to what has been seen in Katsina. What is particular to Niger is primarily the existence of a sociological divide on the issue of Sharia, which actually sheds light, by contrast, on certain aspects of Katsina's evolution. In order to illustrate this sociological divide, the following are two examples. The first is from a recent survey, and the second is from an event dating back to the end of 2012.

In 2014, an Afrobarometer poll revealed that $67 \%$ of Nigériens were in favour of a revision of the constitution that would make Sharia the main source of law in their country. ${ }^{21}$ The distribution of respondents by social categories indicates that this figure represents social groups that form a majority in Niger: people living in rural areas, or those who have had an 'informal' education - in short, the 'popular masses'. Despite its importance, however, this figure is probably small compared

20 For a recent analysis, see Abdourahman Chaïbou (1998), 'La Jurisprudence nigérienne en droit de la famille et l'émergence de la notion de "coutume urbaine", Journal of Legal Pluralism and Unofficial Law 30(42): 157-70.

21 'Au Niger, le soutien est fort mais pas unanime pour l'adoption de la Sharia dans la constitution', Afrobarometer, Note informative $n^{\circ} 156$, September 2014.

http://afrobarometer.org/sites/default/files/publications/Briefing\%20papers/afrobriefno156.pdf 
with the results that a similar survey conducted in northern Nigeria would have yielded, insofar as approval rates of the Sharia Implementation in that region transcend social barriers, as we have seen in the case of Katsina. In Niger, the survey highlighted a significant divide between social categories, especially between people living in urban versus rural areas, and, more precisely, between the educated and the uneducated, with an approval rate of Sharia that decreases as a person's years of education increase, from primary to secondary and then higher education. The survey does not, however, capture possible regional variations, and we will see later how this divide is expressed in the case of Maradi.

Another telling example of this divide comes from the 'General Assembly of the Nigérien Judiciary', a series of debates that took place in November 2012 to examine the problems of such a system. Altogether, its sessions drew more than 500 participants, from all the professions of the legal field and those of law implementation, to initiate the process of modernization of a judicial system that was '[weakened] by corruption and political interventions'. ${ }^{22}$ However, whether in plenary sessions or in committees, the issue of Sharia was never addressed. ${ }^{23}$ Among the participants were two judges who, judging by their clothing, looked like they could hold Islamist views. One of them tried to broach the subject in plenary session but was not successful. He was not silenced but was ignored, as if the question was not even worth addressing. The consensus on the principle of secularism in Nigérien law was so strong that neither the problems 'plaguing' the judiciary - the reason the General Assembly had been summoned - nor the awareness of the existence of a broad popular support for Sharia had called this principle into question. This consensus reflects in part what we learned from the results of the Afrobarometer survey, since justice professionals belong to the social category that is the least keen on Sharia. But, as we have learned from field surveys, this is also a category of public service officials who are consciously invested in the secularism of the state, which is not the case for their colleagues in Nigeria.

Regarding the specific case of Maradi: although the Afrobarometer survey did not offer a breakdown by region, we can assume that support for Sharia is even stronger in that area than the national average, since the social groups that are most likely to support Sharia, rural and uneducated people, are numerically higher in Maradi than anywhere else in Niger. Maradi's urbanization rate is $14 \%$, compared with a national average of $17 \%$, and its literacy rate is $19 \%$, while the national average is $29 \%$. During the 1990 s and 2000s, Maradi also became the region of

22 Excerpt from President Mahamadou Isssoufou's opening speech. See 'Niger: ouverture d' "étatsgénéraux" de la justice, minée par la corruption', 26 November 2012, available at http://www.jeuneafrique.com/depeches/44661/politique/niger-ouverture-detats-generaux-de-lajustice-minee-par-la-corruption/.

23 As rapporteur, I attended the sessions of these états généraux from beginning to end. 
Niger where the Izala movement made the most headway, especially because of its proximity to Nigeria and the constant exchanges between the Izala organizations of Kano and Katsina and those of Maradi. In Maradi, many small Niger-Nigerian sermons are held during Wa'azin Kasa da Kasa (the International Sermon), the international meeting of Izala preachers, which is held sporadically; these sermons are used as a pretext to bring to the city the stars of Izala preaching from Nigerian cities. More significantly, many outlets in Maradi (kiosks and shops) now sell Izala products - mainly audio and video CDs of sermons. Field surveys yielded two interesting findings: no other theological movement is represented in this type of business, and the overwhelming majority of products sold are from Nigeria. ${ }^{24}$

The critical aspect of legal radicalism is expressed in the discourse of Maradian Izala, which actually makes things more difficult for researchers when it comes to interviewing preachers. One preacher who agreed to talk began the interview, before a single question was asked, by calling his interlocutor (myself) a 'philosopher' and an 'emissary of the West' in Hausa. Although the interview had started on an uninviting note, the conversation subsequently took place in a pleasant atmosphere. The seemingly hostile introduction took aim at the targets of Maradian Izala, namely secularism ${ }^{25}$ and the hegemony of the West. Even in this regard, the discourses coming from each side of the border are noticeably different. In Katsina, and in northern Nigeria generally speaking, the critical discourse about the West refers repeatedly to mulkin malaka (colonization) and, much more rarely, to contemporary events. In Maradi, on the other hand, the colonial era was never mentioned and the interviewee focused instead on two situations: first the events in the Middle East, analysed from the geopolitical perspective of a siege, according to which Muslims are attacked by their Western and Israeli enemies, sometimes with the support of unenlightened Islamic powers (the Saudis, in this case); and secondly, Western humanitarian action, seen as an insidious instrument of domination, which, one of the preachers stated, for poor Muslim countries like Niger should be systematically replaced with aid coming from rich Muslim countries. As for the discourse on secularism, it emphasizes that this concept bars Niger from adopting a system of Islamic government, even though, in the opinion of Malam dan Katsina for example, all Islamic doctrines - including that of the Izala's theological opponents, the Tijaniyya - endorse the same theory of government. The interviews also showed that the Izala in Maradi feel weakened

24 When I tried, one day, to buy CDs of preachers from Maradi - including Malam dan Katsina, whom I had interviewed that morning - the seller had to take them out of cardboard boxes that were stored under the counter!

25 Speaking of two countries separated by the same language: while the Izala in Katsina talk of sekulanci, a term derived from the English 'secularism', the ones in Maradi instead speak of layikite, derived from the French laïcité. 
by a lack of support from yan book - that is, secular executives and intellectuals. ${ }^{26}$ While legal radicalism prevailed in Katsina thanks to a collusion between Izala and Islamo-nationalist intellectuals, this latter element never developed in Niger beyond a minority coalition that seems to have lost its momentum in the early 2000s.

It should be noted that, from this perspective, Niger was one step ahead of northern Nigeria due to its earlier political democratization, which dates back to 1991. In Niger, the Islamic-nationalist unrest spurred by political liberalization took place throughout the 1990s, a full decade before their neighbour to the south. During that period, a certain collusion had begun to emerge between the Izala and Islamo-nationalist intellectuals. In Maradi, this was expressed by the Association for the Diffusion of Islam in Niger (ADINI-Islam), founded in that city by a disciple of Sheikh Abubakar Gumi, Yahaya Mohammed, and supported by Izala billionaire Rabé dan Tchadoua. It was also in Maradi that the country's first Islamic magazine, Ikra, was published. It was founded by an Islamo-nationalist intellectual, Ali Zada. The latter was a native of Dosso, a town located in the west of the country, and had no real ties to Maradi where he arrived as a state official. Nevertheless, he was able to develop ties with young Izala-inclined shopkeepers in the city; this was probably the first attempt to form this type of sociological collusion, which, in Nigeria, made it possible to initiate the Sharia Implementation process in the 2000s. However, the activities of ADINI-Islam, like those of Ali Zada, soon focused on Niamey. In the context of centralized Niger, the capital was the place where Islamic radicals needed to exert pressure. For such a movement, however, this was also a much more difficult terrain than Maradi. The opposing side, the proponents of a secular republicanism inherited from the particular colonial dynamic of Francophone countries, was leading the democratization movement, and even if they had to make concessions to Islamic radicals during a stormy decade, the latter were unable to further their project to establish an 'Islamic state' in Niger. Moreover, Islamic radicalism in Niger immediately focused on the political field: no claims to 'restore' Sharia were made, because the memory of the Sokoto Caliphate, and the destruction of its Islamic rule of law by colonial domination is not as vivid as in Nigeria, which constituted the greater part of the Calipathe's territory.

In short, despite its many similarities to Katsina, Maradi is tied to Niamey when it comes to its political evolution. The city is in an ambivalent situation. On the one hand, a popular trend of social and political criticism has developed through Izala preaching that was largely influenced by the religious discourse coming from Katsina and Kano; on the other hand, this trend, also influenced by its Nigérien identity, remains moot since Maradi is not the place from which radical change

26 That was the meaning of the attack I had been the target of at the beginning of one of the interviews. 
can spread in the country. Furthermore, local Izala were unable to gain the support of a critical mass of Nigérien intellectuals and Islamo-nationalist officials at the central level. Despite being the capital of the Izala movement in Niger, Maradi is also a provincial town, compared with both Niamey and Katsina. It is under the cultural authority of the latter and the political authority of the former.

As a result, it could be said that on the one hand, in Katsina, Sharia legal radicalism grew to the point of leading to the reform of the state's judicial system while failing in its project to establish a perfect Islamic society; and on the other hand, in Maradi, legal radicalism did not develop and political radicalism is moot. These variances are rooted in the differences that exist between the Nigerian and Nigérien contexts. To understand the implications of these contrasting developments, including the particular nature of the various types of Islamic radicalism (legal, political, critical) that can be observed, these contexts must be examined using the tools of historical analysis. The emergence of legal radicalism in Nigeria can be explained by comparing the country's historical trajectory with that of Niger - which reveals why this radicalism developed in the northern part of Nigeria without spreading to Niger, a country both close and far away at the same time. A historical analysis comparing the Nigérien context with that of Nigeria also allows us to address, at least partially, the question of the future of Islamic political radicalization in Niger.

\section{Genealogy and implications of legal radicalism}

Legal radicalism is undeniably a distinctive feature of northern Nigeria. Although it can be found in other parts of the Muslim world, it is not common in West Africa. Even in Nigeria, it has little appeal for the Muslim population of the south-west (Yorubaland being significantly Islamized) and seems to be confined to the former territory of the Sultanate or Caliphate of Sokoto and, specifically, to the area of the large emirates - including Borno, which was not conquered by Sokoto but was the subject of its doctrinal dominion. A clear illustration of this can be found in this description of the territory of Sokoto at the end of the $19^{\text {th }}$ century, at a time when its system of government had stabilized and was no longer in a phase of expansion or a process of strengthening:

By the time of British occupation of Northern Nigeria between 1900 and 1903, Muslim rule in the big emirates of Sokoto, Kano, Zaria, and Borno was quite firm and consolidated among Muslims. Non-Muslims who were under effective control in these emirates paid the statutory tax in addition to discharging other obligations towards the Islamic state, but otherwise they managed their internal affairs without interference by the Islamic authorities. Unconsolidated parts of the nineteenth century conquests during and after the Sokoto jihad did not more than recognize a vague suzerainty of the emirs. Large areas of Northern Nigeria, especially in parts 
of the present Bauchi, Plateau, Niger, Kwara, Kaduna, Gongola, and Benue States, lay outside the expanding frontiers of Islam. Some of these were no more than raiding grounds of the Islamic powers, but in others Islamic influences were completely nonexistent. ${ }^{27}$

Aside from Kaduna, Bauchi, and Niger, all the states that initiated a process of Sharia Implementation belong to the zone of the large emirates identified in this description. Since Sharia was already in place in those areas in the $19^{\text {th }}$ century, one might think that its implementation at the beginning of the $21^{\text {st }}$ century may have held a certain legitimacy that would make the concept of radicalism rather doubtful in this case. As mentioned above, when Ahmad Sani Yerima, Governor of Zamfara State, launched the process through a giant rally in the capital in 1999, some reports said that more than two million Muslims - predominantly from the north - gathered to support and applaud the initiative. Furthermore, the initiative was launched legitimately and legally, within the legal framework of the Nigerian constitution and did not meet any opposition from the federal state.

Nevertheless, it is still a form of radicalism, for reasons both historical and contemporary. As illustrated by the example of Katsina, the aim of the Sharia Implementation was not simply to reform the judicial system, but to use this reform, which the people wanted and the constitution permitted, to (re)Islamize the government and society of the northern states with a particular theologicalpolitical orientation. This aim indirectly stems from a historical logic of confrontation, shaped by the British colonial practice of 'indirect rule', a logic that lived on after Independence and has weakened the Nigerian state. Moreover, because its aim was to Islamize the government and society, the Sharia Implementation took the form of a radical project based, firstly, on a complete criticism of Nigeria's system of government and, secondly, on a utopian vision of a world transformed and regenerated by the efficiency of divine law.

\section{Conflicting rules of law}

For a long time, Islam was a minority religion in West Africa, including in its Sudanese region, even though the opposite impression is given by 'the source effect' (the exclusive predominance of Islamic written sources until the first arrivals of Portuguese ships from the Atlantic). It used to be found in cities and courts at a time when most of the population lived in village communities, often without masters or kings (and thus without courts). It went through two periods of expansion in the $16^{\text {th }}$ and then in the $18^{\text {th }}-19^{\text {th }}$ centuries. The first period, which ended with the fall of the Songhay Empire, was followed by a long 'recession', and historical data indicates the possibility of a similar recession after the second

27 C.N. Ubah (1991), 'Colonial administration and the spread of Islam in northern Nigeria', The Muslim World 81(2): 133-48, p. 133. 
period of expansion - especially if, as was likely the case in the 1890s, the Sokoto emirates had been conquered by Rabih Fadlallah, the conqueror of Borno.

This second period of expansion corresponds to the jihad of the Fulani from Torodbe clerical communities; its most brilliant success came in the form of the conquest of the Hausa kingdoms of central Sudan and the creation of the Sultanate of Sokoto in the 1810s. Although all these jihads started as proselytizing war movements, they resulted, once a territorial base had been acquired, in systems of government for which Islamization was not a priority. The geopolitical context and the state of the political economy of the time were obviously insurmountable barriers for any project of that nature. For the jihadist states that were smaller and more isolated (e.g. the imamats of Fouta Djallon and of Fouta Tooro), poorer (e.g. the Liptako Emirate), or had no expansionist agenda (e.g. the Diina of Macina), strategic considerations of survival - in a Sudanese world that was still largely dominated by animist kingdoms or itinerant predatory groups - outweighed the propaganda fidei. ${ }^{28}$ As illustrated by Ubah's description of Sokoto, the sultanate was not a special case, especially in a context of political economy which did not lend itself to mass Islam. We should remember that, at the time, most people lived in village communities that were attached to their traditional religions and their customs; ${ }^{29}$ slavery remained the main method of putting together a workforce; and the mobility of Muslims was contingent on trade routes that were protected by partnerships with people, mostly animist, whose land they crossed. Therefore, emphasis was placed everywhere on establishing appropriate institutions that were designed to govern people or exploit them, rather than to convert them.

These institutions ensured the emergence and operation of an Islamic rule of law in the better-held areas of the jihadist state territories. The emirates provided the most Islamized parts of the territory of Sokoto, as well as of Borno, with religious institutions of government, including Islamic courts and a system of educational patronage, while tax and land administration had been simplified compared with what existed before the foundation of the sultanate - using the jurisprudential principles of Sharia. The 'big emirates' were therefore founded on an Islamic rule of law, a system of government that laid down the rights and obligations of all members of society according to their status in Islam (including those who were not Muslims), governed interpersonal relationships (contracts, family), determined contributions to the community (zakat and other taxes), and, therefore, limited the scope of government to the implementation of the rule of law and - in principle - the promotion of social justice. The act of faith upon which the government was based was not a social contract between rulers and ruled, as was the case with the civic state, but the recognition by all, rulers and ruled alike,

\footnotetext{
28 Proselytism or 'propagation of faith'

29 It is still the case, nowadays, of the Maguzawa in northern Nigeria and the Arnawa in Niger.
} 
of the sovereignty of God, to whom ultimately answered both those who commanded and those who obeyed.

Of course, this was a theoretical ideal; it was often contradicted by a reality consisting of violence, injustice, corruption, or incompetence, as is the case in any system of government that is complex. With colonization, the objective conditions that determined the functioning of this system changed. In particular, an unexpected result of colonial peace and the revolutionary transformation of the West African political economy was the start of a rapid process of mass Islamization through Sudan and the Sahel. This decisive moment in the history of Islam in the region was also accompanied - one could even say contradicted - by the advent of a type of government that was not based on Islam.

Great Britain and France, which took possession of Sokoto and its sphere of influence, also operated on the basis of a rule of law. But the European nations' rule of law, unlike that of Sokoto, was not religious but civic. As with Sharia, the scope of government was determined and regulated by the rights and obligations of individuals, the jurisprudence (Great Britain) or codes (France) governing interpersonal relationships and determining contributions to the community. ${ }^{30}$ This was based on a process of law creation that reflected the sovereignty of the people and its participation in the social contract upon which the status of citizen was based - that is, that of a member of the city, who is equal to others. Here again theory was not without more or less serious failures; but the main failure, in the eyes of Muslims, was that the theory of a civic rule of law could be used against the Islamic rule of law. Since their modes of operation were similar while their sources of inspiration were different, these two 'rules of law' were mutually exclusive, and only force could determine which would prevail. ${ }^{31}$

However, although the ideological discourse of legal radicalism in northern Nigeria emphasizes the idea that what started this movement was the elimination by colonial power of the Islamic rule of law, the reality is more complex and the cause and effect relationship is less direct. Sheikh Abubakar Gumi, the great Nigerian Sharia ideologist, was perhaps the first to define the issue from this angle. In his memoirs, he states that 'the English law was imposed on the Muslims, thereby making it a far more serious issue, because it could not be compared with the Sharia'. ${ }^{32}$ What Gumi meant was that, because of its divine origins, Sharia was

30 Article 14 of the 1789 Declaration of the Rights of Man and of the Citizen of 1789 states: 'All citizens have the right, either in person or through their representatives, to ascertain the need for public contributions, to freely authorize these contributions, to monitor their use, and to determine their amount, basis, collection, and duration.'

31 For an analysis of the trauma that the superior physical strength of the British represented for the Islamic elites of the large emirates and the ways in which they had to adapt to it, see Muhammad Sani Umar (2006), Islam and Colonialism. Intellectual Responses of Muslims of Northern Nigeria to British Colonial Rule, Brill.

32 Abubakar Gumi, Where I Stand, Ibadan, p. 79. 
infinitely superior to English law, the latter being a man-made law that 'betrays its European origins, including those pre-Christian pagan influences which characterize it, and which are particularly odd in our cultural setting'. However, it is precisely because 'English law' and Sharia are comparable in their modes of operation and their field of practice that they are in conflict: one cannot be applied where the other one exists, and the two are mutually exclusive. However - Gumi later recognized this as being the real source of the problem - the British behaved as if the two laws could co-exist. They did not want to eliminate the Islamic rule of law: on the contrary, they extended its territorial scope and strengthened its implementation, but they also wanted to manipulate internal factors and subordinate its mechanisms to the needs of the colonial enterprise.

Indeed, generally speaking, both English and French colonialisms had a tendency, in their early stages, to use Islamic institutions as tools to 'indirectly' govern both Muslim and non-Muslim populations. ${ }^{33}$ Even later, the rapid growth of the Muslim population, which took place through mass conversions, maintained the political relevance of such an approach. At the same time, however, the colonial state intended for this institutional expedient to be managed by the upper ranks of its administration, while controlling the implementation of Islamic law via limitations that had their origins in European modern legal principles. For the British, this control was expressed in particular by the 'repugnancy' clause, which was applied primarily in criminal cases and allowed for local customs and laws to be fully applied provided that they were not 'repugnant to natural justice, equity and good consciousness'. ${ }^{34}$ Consequently, the Islamic rule of law was maintained and even developed across all of northern Nigeria, while being modified and adapted to the needs of the colonial administration and to certain legal and cultural European standards. Thus, for criminal offences, the British permitted Islamic courts to make use of the capital sentence, but only in some cases and provided that the execution be performed by hanging. Incidentally, this adjustment to British sensibility has survived until today. Katsina is the only state in which a Sharia court has used the death penalty - in the case of Sani Rodi, who had been accused of a triple murder in June 2001. Although proponents of Maliki legal orthodoxy including Sheikh Habibu Kaura, a leading figure of the Izala movement in Katsina who witnessed Rodi's execution - protested the fact that the execution method did not conform to the principle of reciprocity, Rodi was hanged and not stabbed to death. $^{35}$

33 Regarding northern Nigeria, see C.N. Ubah, 'Colonial administration', and more recently, Moses Ochonu (2014), Colonialism by Proxy. Hausa Imperial Agents and Middle Belt Consciousness in Nigeria, Bloomington and Indianapolis: Indiana University Press.

34 Supreme Court Ordinance No. 4 of 1876, § 19, 1 Laws of the Colony of Lagos (rev. ed. 1901).

35 In June 2011, Rodi stabbed the wife and the two young children of the Katsina State Director of Security. See Gunnar Weimann, Islamic Criminal Law in Northern Nigeria, pp. 104-8. 
The colonial principles and practices of the British and the French in West Africa were generally more alike than they were different. That being said, at this point we should mention a few differences that became important later, especially after 1945, when colonialism became more liberal and integrated the perspective of the independence of the colonies. Emphasis is often placed on the fact that the British practised indirect rule in Northern Nigeria, while the French resorted to direct rule in all their colonies. In reality, however, the French practised two different policies: assimilation and association. The latter, which posited that Africans were different from the French but were associated with their government, was based on a philosophy similar to that underlying Lord Lugard's 'indirect rule' theory which was applied in Northern Nigeria. But although the effects of association were similar to those of indirect rule, they were also more categorical. The French claimed that an association was created between people from superior and inferior cultures, something that the British also subscribed to but without making it a principle of government. This is not a mere nuance. In the legal field, the British and the French were convinced of the superiority of their systems of law, which they considered more advanced, progressive, and civilized than those that existed in Africa. But they were in no rush to replace the latter, since such an endeavour could be politically difficult and financially costly. What set them apart were the solutions that they offered to the same problem.

In northern Nigeria, the British chose to preserve the legal system of the emirates, as mentioned previously, with what they deemed minor but necessary touch-ups, which, in reality, offended Muslims. In Niger, the French set up a fragmented system in which there coexisted both French law and a regime called indigénat. This regime was itself divided into two rather distinct segments, with, on the one hand, a range of discretionary measures that promoted the colonial enterprise by limiting or invalidating the rule of law (both Islamic and civic), and, on the other hand, a range of customs, or 'customary' law, applicable to 'personal status' and to family. In both cases, British and French, the results were rather inconsistent (and will not be described here), but they led to significantly different situations. One of the major differences was the fact that in French law, the civic rule of law was seen and valued as 'the right of citizens', a rule of law to which it was rewarding and liberating to be 'assimilated', while the indigénat system was seen as the right of the subject, or rather the lack thereof - reflecting the fact that, as Hubert Deschamps ironically put it, the French doctrine was 'the association of man and horse'. ${ }^{36}$ Therefore, in Niger, the elite educated in the schools of colonization, wanting the same rights as French citizens - and thus wanting to stop being subjects - sought the abolition of the indigénat system and the affirmation

36 H. Deschamps (1963), 'Et maintenant, Lord Lugard?', Africa: Journal of the International African Institute 33(4): 293-366, p. 298. 
of equal rights throughout the entire colony, which was obtained in 1946. Access to French law in civil and criminal matters was thus considered, here as in other French colonies, to be progress and a victory in the anti-colonial struggle.

In contrast, in northern Nigeria, the legal hierarchy was not as clear-cut. We can say, simplifying considerably, that business and civil liability laws - which were important for the implementation of public policies - were generally of British origin, while personal status and family laws were indigenous. Criminal law was governed by a code based on British law, but in northern Nigeria, crimes and offences, including those punishable by death, could be adjudicated by higher indigenous courts, those of emirs - even though, as mentioned previously, in the event of an execution, 'British' hanging was preferred over 'Islamic' beheading or crucifixion. In any case, unlike in the French colonies, everyone had access to an entire system that formed an intricate web of laws and procedures with different origins and significance, depending on the type of problem brought to court and / or the part of the colony where one resided.

However - and in parallel with the French colonies - the situation changed in the aftermath of the Second World War. As Nigeria was moving towards independence, the system of colonial law seemed too fragmented and 'backward' for a future modern nation-state. In the $1950 \mathrm{~s}$, a general effort was therefore made to modernize the judicial system, leading to the first reform of the system of Sharia implementation. Citing similar reforms in other Muslim countries, the codification of Sharia at that stage created an Islamic law that was applied only to personal status and family law, referring cases of crimes and offences to the penal code that was adopted nationally. This is referred to as the 'settlement of 1960'. This 1960 resolution therefore created, within the Nigerian legal system, personal status and family laws based on Maliki jurisprudence and adjudicated by local courts ('area courts'), above which was the Sharia Court of Appeal, a superior Sharia court located in Kaduna, the capital of the northern region. Just as Sheikh Abubakar Gumi - the Grand Kadi in the north - had understood it, this represented a subordination of the Islamic rule of law to a civic rule of law, a subordination which reduced Sharia to a mere sub-category of Nigerian law that dealt with the privacy of Muslims in the north, with no jurisdiction over civil cases, let alone over criminal ones. ${ }^{37}$ And so it seemed that in 1960, the civic rule of law had somehow prevailed in Nigeria.

\footnotetext{
${ }^{37}$ A. Gumi, Where I Stand, pp. 78-79. However, at the request of the parties, the Sharia Court of Appeal could handle civil cases, and its judges had a right to sit in on the appeal cases in the High Court's native branch, which gave them an influence on the development of Nigerian law beyond Sharia. See Philip Ostien \& Albert Dekker (2010), 'Shari'a and national law in Nigeria'. In: Jan Michiel Otto, ed., Sharia Incorporated. A Comparative Overview of the Legal Systems of Twelve Muslim Countries in Past and Present, Leiden University Press, pp. 555-612, p. 567.
} 
The same thing took place in Niger but in a more drastic way. Indeed, the indigénat system was abolished in 1945 and replaced by French law; there was no creation of Islamic courts. In theory, the French Civil Code governed Nigérien family and civil matters, but the practical impossibility of consistently applying this code in the family field led to the almost clandestine emergence of a customary law that was originally based on the justice applied by traditional leaders. This customary law is part of the procedures followed by the secular justice system in cases of divorce, marriage, and inheritance, although it is practised in a more Islamized form by the Islamic Association of Niger. These, it should be emphasized, are not courts and are not part of Niger's judiciary: they are comparable to the judicial panels used in Yorubaland in south-west Nigeria to deal with Muslim family cases, resorting to arbitration rather than litigation.

Although the subordination or dissolution of the Islamic rule of law to the civic or secular rule of law seems to have been accepted in Niger - and in the southwest of Nigeria, as we have noted - the ideal of a 'restoration' of Islamic rule of law in the north of Nigeria gradually developed through a rejection of the 1960 resolution, radicalized with each accident of history, and has morphed into a project to build a perfect Islamic society - all the more perfect as it was to emerge from the socio-political chaos into which Nigeria had plunged.

\section{Complete deadlocks}

While colonial indirect rule contained the seeds of legal radicalism, it developed only as a result of setbacks and blockages experienced by northern Muslims after the 1966 coup and during the process of adoption of the constitution of the Second Republic in 1979. Indirect rule had developed and adapted the judicial institutions of Sokoto to Nigeria's colonial context, promising Muslims they would continue to be governed by 'their law'. At the same time, however, this approach was purely instrumental, and so in the end the logic of development of an Islamic rule of law was subordinated to the imperatives of the colonial government. While such a contradiction could be resolved in the colonial context by the authoritarian nature of the ruling regime - Lord Lugard would gladly remind emirs that Britain dominated them thanks to its superior force - the problem presented itself differently once the independent state of Nigeria replaced the colonial state. Dividing Nigeria into three autonomous regions allowed for a full development of the Sharia judicial system, from 'area courts' to a Court of Appeal located in Kaduna, in the northern region. Although critics like Gumi deplored the fact that Islamic courts theoretically dealt only with family affairs, the autonomy of the system seemed to be at least guaranteed in an otherwise favourable political context, since the Premier of the Northern Region, the Sardauna ('Defender') of 
Sokoto, Ahmadu Bello, favoured a gradual Islamization of the government in that region.

The bloody coup in 1966, which aimed to end what its authors - soldiers from Christian south-east Nigeria - considered to be an Islamic hegemony, was followed by the disintegration of Nigeria's regions into a dozen states, which resulted in the dismantlement of the Sharia judicial system. Those events, as well as the prolonged political crisis in Nigeria which ensued, including the Biafra War, also challenged the adherence of northern Muslims to the 1960 resolution and revealed that the main issue, from their point of view, was to achieve unity and ensure the autonomy of Sharia in Nigeria - that is to say, without challenging the secularism of its constitution or breaking with the Christians. Given the intransigence of Christians in the face of a rather modest and 'reasonable' project and the northerners' growing desire for an Islamized government - mainly because of violent crises and the corruption of the federal state - the issue went through transformations that led to the emergence of two types of Islamic radicalism in northern Nigeria: political radicalism and legal radicalism.

The transition back to constitutional democracy, initiated in the late 1970s, first led to a mobilization of northern Muslims for a rehabilitation of the legal autonomy of Sharia. The creation of Sharia courts of appeal in each of the ten new states that had replaced the Northern Region had opened the door to insoluble contradictions in appeal rulings made in several different courts. Reconstituting the unity and jurisdictional autonomy of Sharia, the only way to solve this problem, required the establishment of a federal Sharia Court of Appeal. Moreover, from the perspective of Muslims, such a reform would simply create a situation of equity or equality, since they saw the secular judicial system as an implementation of 'AngloChristian law', which satisfied the country's Christian population while the Muslim population had an incomplete judiciary. But the Christians' take on the matter was very different. From their perspective, the secular law was not Christian. It was a positive law inherited from the colonizers, before which the various categories of the population were equal, regardless of their religious affiliation. From this point of view, Sharia was but the Muslims' customary law and had to be treated equally with the customary law of non-Muslims, instead of enjoying the same status as the secular law. Granting the Sharia such a status, by giving it a federal institution, would amount to indirectly 'Islamizing' the national justice system and sanctioning the 'hegemonic project' of northern Muslims.

During constitutional debates, the solution proposed by Christians was to create Sharia courts of appeal and customary courts of appeal, as well as to grant the states the ability to extend the jurisdiction of religious courts to areas they deemed necessary and desirable - which created opportunities which were later to be seized by proponents of the Sharia Implementation. Despite the opposition of the Muslim 
delegates, it was this solution that was chosen for the 1979 constitution, marking a defeat for the Muslims, since the operational problems related to the Sharia judicial system as it then was remained the same and even worsened because of ancillary reforms.

This defeat for Muslims took place during the Iranian Revolution, an event that offered a glimpse into the possibility of establishing an Islamic state in many Muslim countries and helped to radicalize many young Muslims, including Yakubu Yahaya in Katsina, as mentioned previously. Political radicalism - this project of Islamic hegemony that some Muslims in the north actually aspired to was not the result of the 1979 defeat or of the Iranian Revolution; but from 1979 onwards, it was to permeate the minds of those who wished to solve the problem of the Islamic rule of law in Nigeria. During the 'Years of Lead', from 1983 to 1999, this diffusion of radicalism through the issue of Sharia took place discreetly via the educated classes in the north. When the issue came to the fore again in 1999, it was therefore no longer about simply reconstructing the unity and autonomy of the Sharia judicial system, but about using Sharia to Islamize the government and society. To the first theme - which was moderate and nonsubversive but blocked by the intransigence of Christians - was added the more radical and subversive theme of a utopian Islamic society, which was the result of a political radicalism that, for a long time, had remained confined to marginal groups such as Mohammed Marwa's Yan Tatsine and Ibrahim al-Zakzaky's Yan Shi'a. This is how someone like Yakubu Yahaya and someone like Judge Danladi Abubakar - who in other circumstances would have had nothing in common found themselves in the same fight with a passion and a vision that were genuinely shared. This is also how the project of Sharia Implementation, based on a substrate of legitimacy that has its origins in the government of Sokoto and the mass Islamization of the colonial period, became a radical project - meaning that, like any radical ideology, it had to find its legitimacy in its execution.

At a conference at Bayero University in December 1999, Malam Ibrahim alZakzaky explained why, unlike the Izala and many of his former followers who had joined this movement, he would not support the Sharia Implementation. He said that two conflicts would arise with the implementation of Sharia:

One conflict will be with the constitution which will claim superiority over the Shari'ah and will, therefore, place the Shari'ah under its control and regulations. The other conflict will be with the Shari'ah itself which, as the Law of Almighty God, claims superiority over all laws and therefore cannot accept the supremacy of the Nigerian constitution. ${ }^{38}$

38 Quoted by Ramzi ben Amara (2013), 'We introduced Shari'a - The Izala movement as initiator of Shari'a reimplementation in the north of the country: Some reflections'. In: John A. Chesworth \& Franz Kogelmann, Shari'ah in Africa Today: Reactions and Responses, Brill, pp. 126-45, p. 143. 
The absolute incompatibility between Islamic rule of law and civic rule of law is thus reaffirmed as the main reason behind political radicalism in a country, like Nigeria, where the latter is the reigning system. Al-Zakzaky predicted the failure of the Sharia Implementation and, therefore, refused to support it. Legal radicalism seems to be a dead-end - and political radicalism can lead only to submission under the guise of isolation, as was the case with Zakzaky, or to insurrection, as was the case with another of his disciples who joined the Izala: Muhammad Yusuf, the founder of Boko Haram.

\section{Nigérien epilogue}

What this examination of the Nigerian context reveals is that the fundamental problem of the conflict between rules of law does not really have an equivalent in Niger. The close and numerous ties between the two cities of Maradi and Katsina, which are both populated by Hausas, failed to serve as a conduit for either legal or political radicalism. The French colonial practice, which was more brutal but less hypocritical than its British counterpart, did not incorporate into the development of the modern state religious institutions that could be sources of internal contradictions within its system, and Niger does not have a large Christian population that harbours a paranoid fear of Islamic hegemony. Therefore, there was no need for legal radicalism in Niger; and in a country that never had an equivalent to Al-Zakzaky's Islamic Movement, political radicalism tends to be curbed by the Izala's pragmatist orientation. Their stated goal, after all, has always been to Islamize society through preaching and education, not to destroy the state. Thus, when examining the Nigérien political radicalism of the 1990s, one realizes that those who demanded an Islamic state were Islamo-nationalist intellectuals, not the Izala. What the latter wanted most of all was to be supported by the state in their Islamizing effort, through paid positions for their preaching work or legal and financial support for the preservation and expansion of Franco-Arab education. Similarly, in Katsina, it is clear that the most utopian components of the Sharia Implementation - the implementation of economic and social Sharia by a state that is led by political saints - was the dream of Islamo-nationalist intellectuals, while Izala activists were content with the jobs provided by the $d a$ 'wa commission (missionary Islamization) and the war against 'crime and sin'. From this perspective, the goal of Izala political radicalism, both in Nigeria and in Niger, is not to establish an Islamic state in a revolutionary way, but to bring the state to support the 'Islamization of society' and thus to become ever more Islamic, in order to ensure its legitimacy. That is why, on both sides of the border, secularism is the common enemy. As an Izala preacher in Maradi used to say: 'If tomorrow a dan boko wants to say that he is against secularism, when the government pays for 
the cost of electricity in our mosque, we will have issues. ${ }^{39}$ In Katsina, the government builds mosques. In Maradi, it is not yet the case, but it already pays for their electricity.

\section{References}

BEN AMARA, RAMZI (2013), 'We introduced Shari'a - The Izala movement as initiator of Shari'a reimplementation in the north of the country: Some reflections'. In: John A. Chesworth \& Franz Kogelmann, Shari'ah in Africa Today: Reactions and Responses, pp. 126-45. Leiden: Brill.

CHAÏBOU, ABDOURAHMAN (1998), 'La Jurisprudence nigérienne en droit de la famille et l'émergence de la notion de "coutume urbaine"', Journal of Legal Pluralism and Unofficial Law, 30, 42: 157-70.

Deschamps, Hubert (1963), 'Et maintenant, Lord Lugard?', Africa: Journal of the International African Institute, 33, 4: 293-366

Falola, Toyin (1998), Violence in Nigeria: The Crisis of Religious Politics and Secular Ideologies, Rochester, NY: University of Rochester Press.

GREGOIRE, EMMANUEL (1986), Les Alhazai de Maradi: histoire d'un groupe de riches marchands sahéliens, Paris: ORSTOM.

Gumi, ABUBAKAR (1992), Where I Stand, Ibadan, Owerri, Kaduna, Lagos: Spectrum Books Ltd.

Miles, William S. (2003), 'Shari’a as de-Africanization: Evidence from Hausaland', Africa Today, 50, 1: 51-75.

OCHOnu, Moses (2014), Colonialism by Proxy. Hausa Imperial Agents and Middle Belt Consciousness in Nigeria, Bloomington and Indianapolis: Indiana University Press.

OSTIEN, PHILIP \& ALBERT DEKKER (2010), 'Shari'a and national law in Nigeria'. In: Jan Michiel Otto, ed., Sharia Incorporated. A Comparative Overview of the Legal Systems of Twelve Muslim Countries in Past and Present, pp. 555-612. Leiden University Press.

PeETERS, RUUd (2005), 'The enforcement of God's Law: The Shari'ah in the present world of Islam'. In: Philip Ostien, Jamila M. Nasir et al., Comparative Perspectives on Shari'ah in Nigeria, Ibadan: Spectrum Books: pp. 107-34.

SANI UMAR, MUHAMMAD (2006), Islam and Colonialism. Intellectual Responses of Muslims of Northern Nigeria to British Colonial Rule, Leiden: Brill.

SidDiQue, ABUBAKAR et al. (2000), The Living Conditions of the Talakawa and the Shari'ah in Contemporary Nigeria, publication of the Centre for Democratic Development, Research and Training, Kano.

UBAH, C.N. (1991), 'Colonial administration and the spread of Islam in northern Nigeria', The Muslim World, 81, 2: 133-48.

Weimann, GunNar J. (2010), Islamic Criminal Law in Northern Nigeria: Politics, Religion, Judicial Practice. Amsterdam: Amsterdam University Press.

39 Interview in Maradi on 23 May 2014. 


\title{
Insert A
}

\section{Islamic NGOs in Niger and Nigeria}

\author{
Marc-Antoine Pérouse de Montclos
}

Under the false pretence of redistributing alms (zakat) to the poor, armed groups such as Hezbollah and Hamas have used charity as a facade to establish their legitimacy, expand their social base, and source foreign currency or, sometimes, weapons. In Afghanistan and Pakistan, al-Qaeda initially started as a charity and aid organization for mujahideen fighting against the Soviet Red Army, with the military and terrorist ramifications that we know. ${ }^{1}$ In Sub-Saharan Africa, the question quickly arose as to whether the most radical Islamist movements had also resorted to 'humanitarian' NGOs to spread their ideology, indoctrinate the poor, and find financing abroad.

The debate is not closed. Some researchers are worried about the proliferation of Islamic NGOs, accused of being the economic, political, and diplomatic arms of a Saudi-inspired global jihad or, in its Sahelian version, a Sudanese-inspired one. ${ }^{2}$ On the other hand, other observers emphasize that, far from being a threat, the modernization of a fundamentalist contestation into a formal associative framework demonstrates a level of institutionalization of religious protests through channels of dialogue likely to offer an alternative to the armed struggle. ${ }^{3}$ For example, in the case of Niger, Islamic NGOs work to prevent and manage social conflicts, and three-quarters of these NGOs act as mediators in cases that essentially oppose divergent currents of thought. ${ }^{4}$ What about Nigeria? Its inhabitants are reputed to be very religious, and many follow the prescriptions of their religion to help the poor. According to polls from the Pew Research Center, $80 \%$ of Muslims and $83 \%$ of Christians say they donate to charity through their mosque or church. ${ }^{5}$ However, the country has few development NGOs or emergency aid organizations for its size. ${ }^{6}$ In comparison, Niger is much better endowed, especially since the drought of the early 1970s. In 1975, there were already 14 NGOs, including 12 international ones, and we count about

1 Al Qaeda strategists advise jihadists to set up NGOs to live their faith to the fullest by avoiding the corruption of public institutions in impious states. As-Suri, Abu Mus'ab (2004), The Jihadi Ideology and Constitution of the Global Islamic Resistance Call, n.d, art.18.

2 Mohamed Salih, MA (2004), 'Islamic NGOs in Africa'. In: Alex de Waal, ed., Islamism and Its Enemies In The Horn Of Africa, London, Hurst, pp.146-81.

3 Perouse de Montclos, Marc-Antoine (2011), 'Islamic Humanitarian NGOs in Africa: a threat or a blessing?', Global Security 16: 9-19.

4 Hassane, Moulaye, Marthe Doka \& Oumarou Makama Bawa (2006), 'Study on Islam Practices in Niger', Niamey, DANIDA, p. 84.

5 Lugo, Luis et al. (2010) Tolerance and Tension: Islam and Christianity in Sub-Saharan Africa, Washington DC, Pew Research Center, 324p.

6 Perouse de Montclos, Marc-Antoine (2005), 'Bad governance and NGOs: The Nigerian exception', Autrepart 35: 127-42. 
a hundred today according to online directories. ${ }^{7}$ In 2005, it was estimated that Niger had 54 Islamic associations, 44 of which duly registered. Islamic-charities in Nigeria are more difficult to quantify in this regard. Historically, the region has had few foundations (called waqf or hubus), because - unlike territories within the Ottoman Empire - the royalty at the head of pastoral or mercantile societies rewarded their vassals with tax exemptions or military service exemptions rather than with land concessions. ${ }^{8}$ It is also necessary to distinguish local NGOs from branches of larger organizations coming from Saudi Arabia, Kuwait, Sudan, Libya ... or Europe: the Muslim World League (Rabitat al-'Alam al-Islami, founded in 1962 in Mecca), the Organization for the Call of Islam (al-Dawa al-Islamiyya, founded in 1972 in Tripoli), or specialized agencies - in education, scientific cooperation, development, or banking - of the Organization of the Islamic Conference (launched in Rabat by the Saudi king in 1969).

Among foreign organizations, the only one whose name is indirectly related to the history of Boko Haram is a British foundation: the Muntada Islamic Trust (al-Muntadah al-Islamiyya), which was established in London in 1986 and has for a time funded mosques in Nigeria, before being banned by the authorities in 2004 and having handed over its activities to a local association, al-Furqan. ${ }^{9}$ Located in Kano, the NGO quickly worried the leaders of Qadiriyya and Tijaniyya, who demanded its expulsion in September 2002. The Sudanese director of the Muntada Islamic Trust branch in Maiduguri, Muyhiddin Abdullah, was arrested in February 2004 and accused of funding the Taliban rebels in Yobe. Before being murdered in April 2007, probably by Boko Haram, one of the leaders of the most conservative current of Izala, Sheikh Ja'afar Mahmud Adam, was himself about to report to the authorities the activities of extremists who, funded by the NGO, had tried to use its Kano mosque to recruit and train terrorists, believed to have been involved in his assassination. In the years that followed, the governments of Kenya, Chad, and Mozambique also expelled representatives of the Muntada Islamic Trust. However, a parliamentary inquiry conducted in the United Kingdom in 2012 was unable to prove the direct involvement of this NGO in terrorist networks.

In fact, there is no evidence of an operational link between foreign Islamic charities and the sect founded by Mohammed Yusuf and now known as Boko Haram. Actually, even fundamentalist sheikhs criticize the proliferation of Islamic associations, which are accused of sowing discord (fitna) within the community of believers (ummah).$^{10}$ In many cases, it is rather the Muslim establishment that opted to institutionalize, register and legalize charities. Connected to the Society for the Victory of Islam (Jama'atu Nasr Islam, launched by the Qadiriyya in 1964) and chaired by the Sultan of Sokoto, the Supreme Council for Islamic Affairs (SCIA) thus deals with helping widows and orphans and granting micro-credit to peasants.

Historically, Sufi brotherhoods were the first to develop NGO networks. In 1963, for example, the Kano-based Tijaniyya established an 'avant-garde' called the Heroes of Islam (Fityan alIslam). In competition with Sokoto's Qadiriyya, it then set up a first-aid service in 1978, the same year as the launching of a rival and Wahhabi-inspired organization, the Society for the Eradication of blameworthy Innovations and the implementation of the Sunnah (Jama'at Izalat al-Bida wa Iqamat al-Sunnah). The latter did not lag behind for long and started developing social actions to expand its influence by establishing branches across the country, mainly in the north, where it has opened health clinics for the poor. For their part, the Heroes of Islam have initiated awareness programmes on pre-marital AIDS testing, a position that may have triggered the split of a

http://www.portail-humanitaire.org/annuaire/pays/afrique/niger/

8 Fisher, Humphrey (1975), 'The Central Sahara and Sudan'. In: Richard Ray, ed., The Cambridge History of Africa, vol.1: From the Earliest Times to c. 500 BC, Cambridge, Cambridge University Press, p. 59.

9 Its Syrian-born founder Muhammad Surur Ibn Nayif Zayn al-'Abidin had first led in Saudi Arabia a Salafist movement, Sahwa, criticizing the 'laxity' of the ruling Wahhabis in Riyadh; his position had resulted in his being expelled from the country in 1974 and seeking refuge in the United Kingdom.

10 This is the case, for example, of Mallam Mai Zabura in Maradi. See Sounaye Abdoulaye (2010), Muslim Critics of Secularism. Ulama and Democratisation in Niger, Saarbrucken, Lambert Academic Publishing, p. 35. 
dissenting group in 1995, called the Young Heroes of Islam (Munazzamat Fityan al-Islam). Finally, both the Izala and the Tijaniyya set up self-help groups (yan agaji) to provide security for their religious gatherings and relief in cases of emergency.

Opposed to Sufi brotherhoods and to the Izala 'eradicators' at the same time, the 'Shia' movement is undoubtedly the one which has sought most to institutionalize its social actions in the form of NGOs. Its founder, Ibrahim al-Zakzaky, started his political career as an activist of an organisation, the MSS (Muslim Students Society), whose Center for Islamic Thought was to participate in AIDS prevention programmes. Since then, the so-called 'Yan Shi'a' have created many NGOs, including a security arm (Harisawa), a fund for the needy (Zahra), a doctors' charity named ISMMA (Islamic Movement Medical Association) and, on the Iranian model, a martyrs' foundation (Shuada) to care for the families of members killed by the Nigerian security forces. Social actions have been particularly developed in the field of health, with sanitation programmes and pre-positioned ambulances in Zaria, Katsina, Kano, and Sokoto for emergency services. On occasion, ISMMA volunteers have even made up for the lack of doctors during strikes in hospitals. ${ }^{11}$

11 Alkali, Muhammad Nur, Monguno, Abubakar Kawu \& Mustafa, Ballama Shettima (2012), An Overview of Islamic Actors in Northeastern Nigeria, Oxford, Nigeria Research Network Working Paper No. 2. 



\section{Part II \\ Questionning the Salafi Model and its cross-border effects}





\title{
Cross-border preaching between northern Nigeria and Niger: Practices, actors, and implications of wa'azi
}

\author{
Abdoulaye Sounaye
}

\section{Introduction}

Many scholars of Islam in Africa have drawn attention to the growing significance of preaching in the past twenty years (Miran 2007; Schulz 2012; Gomez-Perez \& Madore 2013; Sounaye 2014; Thurston 2016). Among the factors that contributed to this phenomenon are struggles for power and legitimacy that came as a result of the emergence of new actors and currents - such as the Izala movement - as well as the growing mobility and visibility of religious actors, particularly after the 1990's liberalization (Brigaglia 2007; Holder 2009; Gomez-Perez, LeBlanc \& Savadogo 2009; Zakari 2009; LeBlanc 2012; Schulz 2012; Sounaye 2012). In West Africa, this has transformed discursive frameworks and led to new forms of interaction within religious communities and between those communities and the rest of society. These socio-political dynamics have greatly contributed to a restructuring of the religious sphere and its sociabilities; it has also reshaped the mode of circulations of religious ideas.

In this context, the importance of sermons - wa'azi in Hausa - has been paramount, particularly in helping rally the masses around the Izala Salafi reform project, its theological, political, and social agendas. To what extent do wa'azi contribute to the dissemination of religious ideas? How do they lend themselves to socio-religious modes of action that transcend national borders? To what extent do they contribute to the circulation of ideas that have gradually revolutionized their socio-political environment? What are the potential outcomes of this circulation at a time when the Salafi issue (Sounaye 2016; Thurston 2016) has become one of the most debated in West Africa? ${ }^{1}$

I use this phrase in reference to the 'Muslim issue' (French: la question musulmane), which was a central concern during the colonial period and until the early 1980s. I would argue that this issue has been, 
Focusing on Niger and Northern Nigeria, this chapter seeks to answer these questions, which are at the heart of the governance of religion in both the region and beyond. The chapter examines also the ways in which religious actors understand and make use of the public sphere. To fully grasp this process, we must look beyond state logics, which focus on violence and disorder while prioritizing a securitization approach to Islam.

Map 4 Geographical distribution of Sounaye's fieldworks

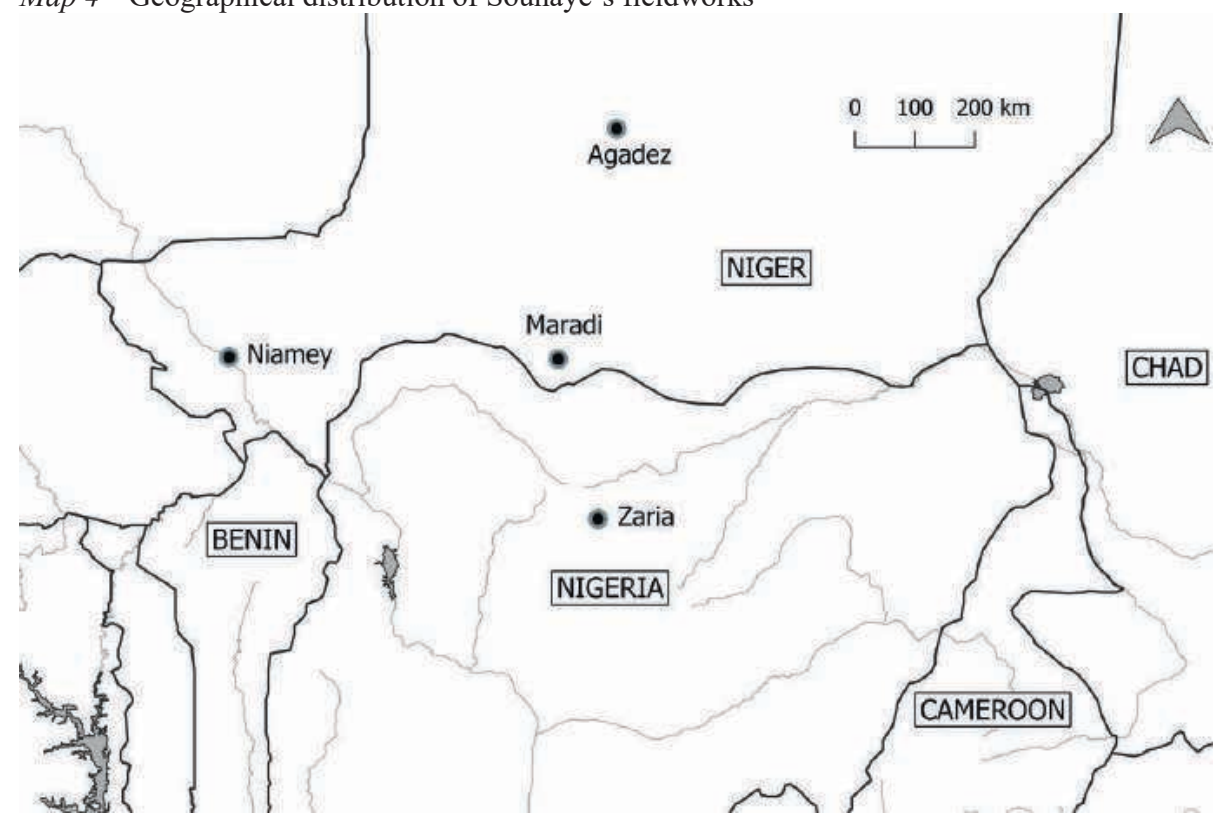

Drawing on the results of two years of research, I will analyse here the ways in which the wa'azi have become, in this Nigeria-Niger sociocultural area, one of the instruments that serve the dissemination of religious ideas, the production of norms, as well as social and political values. Furthermore, wa'azi offer a framework for the routinization of a community whose actors are defined today by their cross-border dealings and mobility. As the case of wa'azin kasa ${ }^{2}$ will show, it is important to approach these actors beyond their national and state markers, as they have become agents whose discourses and actions help them transcend the

since the late 1980s and early 1990s, supplanted by the 'Salafi issue' (French: la question Salafi), in a context that has seen what many analysts referred to as an 'Islamic revival' (Otayek 2000; Fourchard 2005; Gomez-Perez 2005; Filakota 2009; Zakari 2009; Saint-Lary 2012).

2 A preaching rally that usually lasts several days. See section below. 
territorial borders of Niger or Nigeria, and offer them a foothold in a religious economy of regional and even global scope. Their ideas circulate particularly through 'new' media, which have become popular and accessible to an increasing part of the population.

Analysing contemporary Salafi preaching using wa'azi as a point of departure will give us an insight into the dynamics that shape not only discourses in a context of religious liberalism, but also the sociabilities characteristic of contemporary Islam. It appears that in the Sahel today, and due to the violent appropriations of Islam and increasingly divided politics, Salafism has become a major sociopolitical issue that challenges governance at both local and national levels. Obviously, violent jihadism and political conflicts have drawn increased attention to the circulation of religious ideas and the mobility of actors who are committed to a Salafi moral order, especially in a region that must now deal with the consequences of Boko Haram (Pérouse de Montclos 2014; Higazi 2015; Kassim 2015; Voll 2015), the collapse of the Libyan state following the fall of Gaddafi's regime (Mattes 2014), and ethno-religious struggles in northern Mali (Hernann 2016).

On a more theoretical level, in the current context where the Salafi issue affects as much the political field as the everyday life of ordinary citizens, it is important to understand not only discourses and modes of action, but especially the infrastructural frameworks that are intended to promote and strengthen this moral order. In other words, the analysis proposed here accounts for a religious culture whose emergence wa'azi greatly contributed to. Such an approach will highlight the ways in which these religious events and discourses become political acts, but also how power is constructed and religious communities are brought together. In many ways, public preaching and the diverse appropriations of religious discourse led to a redefinition of moral, political, and cultural references. The Islamic activism that started in the 1980s-1990s - just after the Iranian Revolution and the progressive transnationalization of the Izala movement - greatly influenced this dynamic.

The materials used for this contribution were collected during two trips to Zaria (in December 2014 and November 2015), Nigeria, and a series of trips to Maradi, Niamey, and Agadez, Niger. As will become apparent, the issue at hand is not only a cross-border one; it also has a transnational dimension insofar as the circulation of ideas is not limited only to the border area. Similarly, the mobility of religious actors and the dissemination of their discourses go beyond Niger and Nigeria and encompass countries such as Cameroon, Ghana, Benin, Burkina Faso, Togo, and Chad. 


\section{Niger-Nigeria: A shared Islamic public space}

To Niger, Nigeria is a 'big brother' not only in economic, but also in religious terms (Nicolas 1981, 1986; Miles 1994; Souley 2005), as shown by sustained interactions between Nigerian and Nigérien Muslims. This relationship calls for a critical examination of Islam's trajectories beyond the borders of the postcolonial state, especially with the developments the regional Islamic sphere has experienced in the past three decades.

However, we need also to keep in mind the sociohistorical process that made the environment that now spreads over Nigeria and Niger. First, there is the jihad of Usman dan Fodio, which reshaped the political map of the region and led to greater religious integration. Then, the cultivation of Islamic learning linked communities across what was referred to as the western Sudan - for example, through the Qadiriyya and Tijaniyya communities - illustrating both the precolonial and transnational significance of Islam in the area now shared between the two countries. While the ties and exchanges between Muslim actors and communities in the region go back several centuries, it must be noted that colonial rule has significantly affected them, imposing on them a reorganization of communities and a re-articulation of the relations between these communities. In general, the scale of exchange and mobility linked to the major centres of Islamic learning like Maiduguri, Agadez, and Kano, strengthened the role of Islam in the production and maintenance of ideological, political, and cultural references throughout the region (Dewière 2017; Miles 1994).

More recently, with the emergence of the Izala movement in the 1980s, and especially in the 1990s (Umar 1993; Loimeier 1997; Kane 2003; Brigaglia 2007; Sounaye 2009), cross-border ties and relations have reinforced the idea that these two countries are part of the same Islamic cultural space (Nicolas 1975, 1980; Miles 1994; Souley 2005; Hamani 2007). Certainly, Niger and Nigeria have had different political trajectories, especially since independence, but with a 1,500kilometre border, their socio-economic and cultural connections are considerable as can illustrate the numerous Muslim networks between the two countries.

With Independence and the subsequent coming to power of national elites, Islam gained even more significance in the political life of both countries (Loimeier 1997; Nouhou 2005; Souley 2005; Zakari 2009). This was particularly the case in the Nigerian context where, prior to Independence, Islamic institutions had a significant role in social and political governance (Kane 1997; Loimeier 1997; Schmitz 2000; Umar 2005). But while the Islamic sphere enjoyed relative freedoms of organization and action in Nigeria, in Niger - due to the republicanism inherited from colonial rule - the central state was rather more controlling of Islam, following a policy inherited from the French colonial system, and later continued 
by the Nigérien state, especially under Kountché's military regime (1974-1987). Therefore, unlike in Nigeria, in Niger, governing Islam meant primarily imposing a statist orientation on Muslim actors. This approach led to the institutionalization of the Association Islamique du Niger (AIN), which until 1990 was the only formally recognized Islamic organization in Niger.

In Nigeria, the rise of the Izala movement and the first generation of its followers who were locally trained, set in motion what may be called today an Islamic revolution. Fuelled with an anti-Sufi discourse calling for Islamic reform (Umar 1993; Loimeier 1997; Kane 2003), this development resulted in a polarization which, to this day, marks the religious sphere in Nigeria and the region. Neman Ilimi (the search for Islamic knowledge, in Hausa) ${ }^{3}$ and cin rani (dry season migration, in Hausa), ${ }^{4}$ two well-established practices in the region (Heiss 2015), combined with various appropriations of Islam to lead to what may be called a public religious sphere shared by both countries. This is all the more important to emphasize as mobility and interactions among populations have created networks and introduced forms of religiosity with shared references. Even today, Nigerian centres of Islamic learning remain the favourite destinations for many Nigériens. ${ }^{5}$

The Izala movement has played a decisive role here. With its Islamic reform project that took shape in the late 1970s, Izala succeeded in spreading - in Nigeria and Niger, via multiple networks - a culture of protest and of theological and intellectual debate, which have inspired most of today's religious trends. Media savviness and new preaching methods proved instrumental to this development. This impetus has propelled religious actors onto the public stage, but it has also allowed the religious sphere to restructure from within and somewhat escape state regulation and control.

In Nigeria, the demand for a full implementation of Sharia - a political demand that spread across the north in the early 2000 s - eventually prevailed, in part due to Izala's activism, which has now become a leading social and political influencer (Kane 1997). The constitution of an autonomous Salafi discourse, shared today throughout the region, can be traced back to that period, the golden age of antiSufism.

3 In reality, in this context, the practice refers to the continuation of Islamic studies once the learner has finished memorizing the Quran (when he becomes known as alaramma). This corresponds to higher education and a specialization in the Islamic curriculum of the sub-region.

4 Generally speaking, from villages towards cities. Here, the concept refers to the migration of thousands of young Nigériens towards Nigeria's large urban centres.

5 During the 1980 Maitatsine uprising, for example, there were already many young people from western Niger who were in Nigeria to further their studies at Islamic educational centres in Kano. 
The Sufi / anti-Sufi opposition remains one of the main discursive markers of Islam in both countries; ${ }^{6}$ although we are witnessing dynamics on which this polarisation has only a minor impact. ${ }^{7}$ The diversity of Islamic groups includes, for example, the Kala Kato (also known as Qur'aniyun), Shiites, Tablighi Jammat, and even the Ahmadiyya, groups that represent visible minorities in the region. The Shiite movement, for example, has consolidated and gradually strengthened its cross-border networks, an indication that its status and interactions with other religious currents are becoming increasingly important factors in the Islamic dynamics of the two countries. For the moment, its activism is still localized and much less worrying for the state than the violent jihadism of Boko Haram, for example.

I will argue that it was essentially the rise of the Izala movement that both strengthened and solidified this regional public space and the development of houlda (cooperation, exchange) that now allows Muslim actors in Niger and Nigeria to hold gatherings, including preaching rallies in both countries. The wa'azin kasa is one of the best illustrations of this development.

In sum, even though on each side of the border the political systems are different, the two countries share an integrated Islamic sphere. It should however be emphasised that certain issues and concerns are exclusive to one or the other country. The issue of Sharia, for example (analysed in this volume by Abdourahmane Idrissa), was central in Nigeria but was much less present in Niger, or, at least, not in the same way. The Shari'a issue was never politicized in Niger, despite attempts by some Islamic organizations seeking to break with French secularism. Unlike in Nigeria, Shari'a proved no mobilising issue in Niger. In the same way, the controversy revolving around the Family Code, which continues to mobilize Islamic organizations from various sides in Niger, is simply not an issue in Nigeria. Nevertheless, Izala trajectories in the two countries are comparable, the cross-border networks linking Sufi organizations and communities (especially those of the Tijaniyya), as well as the gradual transnationalisation of the Shiite movement are additional evidence of a shared Islamic public sphere. Certainly, the mobility of preachers and other translocal actors (cf. Loimeier 2006) whose discourse and initiatives transcend national borders has strengthened this sphere.

However, in light of the rise of violent jihadis now strong enough to challenge the authority of both states, this common public sphere needs to be conceived as a space in flux, rather than as a fixed and already established order. In any case, at

6 For example, the bid' $a$ and the shirk are still key targets of the Salafi discourse I discuss here, even if they are no longer sources of violent confrontation as was the case in the early 1980s. However, the sermons of Muhammed Yusuf, Sheikh Albani Zaria, Issa Pantami, and Kabiru Gombe illustrate the permanence of the discourse on shirk and bid'a.

7 In this regard, it is important to note the alliances in the Islamic sphere where Tijanis and Shiites, for example, tend to ally in response to their Salafi critics. 
the heart of this dynamic is the preacher (mai wa'azi, in Hausa), a cross-border activist who relies on a proselytism and discursive practices that have prompted a revolution whose impact is yet to be grasped and fully theorized.

\section{The wa'azi: A religious address}

The Hausa term wa'azi comes from the Arabic word wa'z, which refers to an exhortation intended for the masses - believed to be unlearned - to whom one would like to explain and transmit the prescriptions of their religion. The wa' $z$, a form of public address in Islam (Berkey 2001; Talmon-Heller 2008), has historically been reserved to the ulama, as were the kuthba (the Friday prayer sermon) and the fatwa (a legal opinion generally issued by scholars). Wa'azi can be held in a mosque, outdoors, in public spaces, or in the street, as is increasingly the case in some West African cities. Madrasahs and wa'azi represent the two most popular channels of transmission of Islamic learning in the cultural area studied here. In this context, wa'azi is often the main place of interpretation of the Quran. But unlike the classical and formal exegesis of the Quran (tafsiri, in Hausa) which is the preserve of marabouts and established scholars, the wa'azi is less formal and consequently more open to ordinary Muslims, with little or no-Arabic, and less knowledgeable about the Quran and the Sunnah.

Across the region, the popularization of the Quran is an important practice that has shaped Muslim discourses (Moulaye 1995; Tamari 1996). This was even more noticeable in the 1980s-1990s, when oppositions within the Muslim world increased and led to a polarization of Islam. The idea of Sheikh Abubakar Gumi, the central figure of the Izala movement, to promote preaching has led to appropriations of religious discourse that have gone beyond the mere hermeneutic of the Quranic text (Loimeier 1997; Brigaglia 2007). His Radio Kaduna tafsir played a central role in revolutionizing the Islamic sphere in Hausa-speaking West Africa, for it was mainly through this mass media and Gumi's recorded sermons that the reformist discourse of Izala was decentralised, propagated, and popularized.

Very little of the classical and scholarly tafsir remains in the wa'azi I focus on. It is still inspired by the Quran and finds justification in divine injunctions such as 'Iqra!', ${ }^{8}$ just like the tafsir. However, in many respects it rests on an art of speaking rather than on an exegesis, even if it occasionally refers to the Qur'an and the Hadiths. A popular mode which finds its raison d'etre in the fact that the masses need intermediaries, translators, and interpreters of the tradition, in practice, it conversational and treats the scriptures as a supporting material. Furthermore,

8 Prophet Muhammad was instructed by Angel Gabriel to 'read!' or 'recite!' the verses from the Quran that had been sent to him. 
while a tafsir follows the linear order of the Quranic text, a wa'azi can evoke any given verse as long as it supports the argument of the preacher.

Many preachers are also quick to emphasize the responsibility of Muslims, from the novice to the most learned, to pass on the tiniest piece of knowledge they may have. From this perspective, wa' $a z i$ is neither intended for the scholars; since the goal is the popularization of Islamic teachings, every Muslim is a potential preacher, at least according to the Salafi discourse. This explains mhy many preachers today are relatively young, especially when compared with their predecessors a few decades ago, who were allowed to preach only once their credentials in Islamic sciences had been established.

Being a practice of exhortation, a way to express popular religiosity, wa'azi have become in the last three decades the main tool of Islamic preaching, both in Niger and in Nigeria, especially for an enterprising and conquering Salafism inspired by da'wa. Indeed, with the Salafi call to reform Islam this practice gained popularity, transcending its erstwhile spatial ${ }^{9}$ and temporal ${ }^{10}$ limits and becoming the art of anyone, any place, any media, and any actors, regardless of their gender (Sounaye 2012).

Even more remarkable is the fact that around wa'azi an infrastructure emerged that has been used to train an assertive youth, a committed leadership, and preaching celebrities whose popularity reaches far beyond local and regional boundaries. There is probably no Hausa-speaking region where the wa'azi of Sheikh Abubakar Gumi (1922-1992) have not been heard. For other figures of contemporary preaching - such as Abubakar Gero, Kabiru Gombe, Sheikh Adam Jafar, and Sheikh Albani, just to name the most popular ones - wa'azi have even become a profession whose legitimacy derives from the $d a^{\prime} w a$, the call to Islam.

In fact, the masu wa'zi (sg. mai wa'zi) ${ }^{11}$ see this form of preaching as a way to participate in the promotion of an authentic religiosity that distances itself from bid'a (blameworthy innovations) and shirk (idolatry) to establish tawhid (absolute monotheism) and ritual puritanism. It is also through wa' azi that rivalries between trends (Tijaniyya / Izala, Izala / Kala Kato, Izala / Shiites) or even between religious leaders (Yusuf (1970-2009) / Jafar (1960-2007), Da'hiru Bauchi / Kabiru Gombe) have often been expressed. Sheikh Albani, the great Salafi preacher from Zaria, for example, devoted a series of wa'azi to his relationship with Namadi Sambo, vice president of Nigeria between 2010 and 2015. Similarly, the Izala / Tijaniyya feuds have been and still are at the centre of many wa'azi in both

\footnotetext{
9 It is held at the mosque, but mostly beyond this space, in cultural centres, in a stadium, or simply in the street.

10 Including Mawlid and Ramadan.

11 Lit. 'those who preach', or those whose role is to preach.
} 
countries. It is also through wa'azi that the Izala honed its anti-Shiite rhetoric, equating Shia to enemy of Islam (K. Gombe). ${ }^{12}$

Overall, the activism that developed around wa'azi has been central to current dynamics in Islam. A good illustration is the way in which Sheikh Albani of Zaria (1960-2014) used his wa'azi to build a community (daarul-hadeethis-salafiyyah) and a sphere of influence that went beyond Zaria and Nigeria. For some Nigerian politicians, Albani had even become the spokesperson of a key segment of the population, and definitely a voice they would prefer not to antagonize. Courted by politicians, businessmen, and other 'big men', also very critical of both Boko Haram and the Shiite movement, he acquired through wa'azi a political and religious influence. This position probably played a role in his assassination on 1 February 2014. ${ }^{13}$

The case of Albani illustrates how far-reaching the influence of a preacher can be in the current religious context in the region. His popularity has spread well beyond Nigerian borders and in particular into Niger, where he has become remarkably popular among students, civil servants, and especially women. In Hausa-speaking regions, Kabiru Gombe, Abubakar Giro, Jafar Adam, and Nyandu Ghana are also familiar voices and charismatic figures who contributed to the dissemination of the Izala and Salafi discourse. Their recorded wa'azi are easily found in any local market of the region. ${ }^{14}$

In short, wa'azi as a form of oral and public preaching have mostly developed with the emergence and normalization of the Izala movement. Seeking to gain a social base, this trend needed wa'azi to be present and maintain visibility in the public sphere. In this respect, wa' $a z i$ was the main instrument used by the Izala to secure that presence, simultaneously making this practice the main activity of their campaign for the re-Islamization of society in both urban and rural areas, and beyond national boundaries, wherever they hoped to mobilize and convert people to their new religious ideology (Meunier 2000).

There is no doubt that the intensification of this practice has allowed Muslims to move beyond classical modes of transmission of religious and Islamic ideas, while also diversifying the modes of action of religious actors. Both within and

12 At the time this chapter was being written, a controversy had just erupted between the Tijaniyya and the Izala movement in Nigeria over the status of the Shiites and the danger that this current represents for peaceful coexistence. Once again, it is through the wa'azi that these differences and positions were relayed.

13 Boko Haram claimed responsibility for the assassination of Sheikh Albani Zaria in a video message recorded by its leader, Abubakar Shekau, and broadcast on 19 February 2014.

14 In this category, we should not forget to mention Muhammad Yusuf, master ideologue of Boko Haram's jihadism, another popular preacher from the Izala school of thought. He is known for his sermons, which played a key role in the uprising against a moral and political order that he considered corrupt and antiIslamic. His case is a perfect illustration of the internal contradictions of Salafism. By emancipating himself from Sheikh Jafar, his mentor, he created the conditions for the emergence of a Salafism that was independent of Izala. 
outside Muslim context, wa' azi have served power struggles, the spread of specific groups and the defense of Islam, a leitmotif for many. It is through wa'azi, for example, that preachers from both countries levelled claims against the polio vaccination campaigns in the early 2000s (Yahya 2006; Sounaye 2011b). Wa'azi also served an organization such as Boko Haram to emerge, spread, and maintain a powerful and mobilizing discourse (Anonymous 2012; Apard 2016; Thurston 2016a) against what it considers to be a destructive Westernization (turanci). From this perspective, wa'azi not only help shape the dynamics of the religious sphere, but they have also become an instrument of public debate - a platform where religious actors can speak out, campaign, and protest. Thus, coupled with the desires of building specific communities, especially with the intention of reforming Muslim practices and establishing an authentic Islam - one that is rid of its so-called corrupting innovations - they have become an essential mode of presence and action of transnational socio-religious actors.

As a result, the impact these religious entrepreneurs have had on social and political dynamics can be seen in the growing importance of the networks and communities they have established, but also in the ways in which political, administrative, or customary authorities in both countries have tried to address what could now be called the Salafi challenge. Nigérien authorities - in Zinder and Maradi, for example - had to deport Nigerian preachers because their sermons were allegedly disturbing the peace and thus represented a threat to public order and social cohesion. ${ }^{15}$ This attitude or concern, depending on how one perceives it, is not exclusive to Niger. Nigerian authorities are also concerned about 'Nigérien infiltration' and the involvement of Nigériens in violent and religiously motivated insurrections. ${ }^{16}$ The cases of Boko Haram and Maitatsine illustrate these cross-border apprehensions. In both cases, Nigerian authorities claimed a significant involvement of 'young people from across the border,' i.e Niger.

From the forms, tools, and actors of Salafi preaching I have presented here, one could easily draw the notion of a borderless wa'azi, which is certainly one of the main characteristics of a cross-border religious public sphere. This space has been constructed and facilitated not only by Hausa, the lingua franca of the region, but also by $w a$ 'azi, as an instance of debates and polemics and therefore cultural and political practices. Similar processes have been observed elsewhere in the Muslim world, particularly with the development of new communication technologies. Anderson and Eickelman (1999), for example, have emphasised the impact of fax, radio, and TV in the structuring of an Islamic public sphere in the Middle East. In the context under consideration here, it seems that the actors at the heart of wa'azi can no longer be confined to their local or national origin because they imagine

15 Sahel Dimanche, 18 October 1996.

16 These concerns were often relayed by BBC Hausa. 
and perceived themselves as members of a community that transcends state borders. In this sense, as the wa'azin kasa I discuss below shows, wa'azi has become a key element in the social and religious engineering of cross-border Salafism.

\section{The wa'azin kasa of Maradi: A community-building initiative}

As we have seen, wa'azi and the actors they involve have greatly changed over time. The same can be said of the occurrences, the temporality, and the spaces of preaching. In fact, the classical and local wa'azi also became supplemented by wa'azin kasa, a preaching rally that hosts dozens of preachers over several days to promote reformist discourse (Sounaye 2014). Bringing together thousands of participants, this practice has developed mostly among the Salafi. In this context, wa'azin kasa is one of the key vectors of the circulation of ideas and the mobility of Salafi actors between Niger and Nigeria. They thus play a role in the construction of religious communities, an aspect which is used to justify the wa'azin kasa by its organizers, but also the political and administrative authorities.

In March 2014, the Ih'yahu Sunnah of Niger organized a wa'azin kasa to raise funds for the construction of a social centre that would comprise a clinic, a madrasah, and an orphanage. The cost of the complex was estimated at 148 million CFA francs (about USD 300,000). After three days of fundraising, the organizers were still far from their goal, but they had already planned a series of sermons to raise additional funds. In Niger and in Nigeria, wa'azin kasa is often associated with a social infrastructure project, the most common ones being madrasahs and mosques. In reality, wa' 'azin kasa are used to put to work a social philosophy that requires community members to support the initiatives of their organizations and 'to be sensitive to the sufferings of others and to share their wealth with the needy (miskinnai, in Hausa)' (Alfa Issa). ${ }^{17}$ It is therefore part of the taimakon addini (Hausa: helping the religion) which calls for a personal investment and which, in Izala circles, has been interpreted as an obligation. For at least two decades, wa'azin kasa has become one of the preferred means of meeting this obligation and assuming the responsibility of being a good Muslim. In this process, the wa'azin kasa has gradually established itself as an instrument of the construction of Izala's community, giving it the means not only to maintain its discourse in the public sphere, but also to translate this discourse into social initiatives. In so doing, the supporters of Izala Salafism showed that being Izala did not simply mean embracing the ideological and theological positions; it also meant contributing materially in building the community.

17 One of the organizers of wa'azin kasa Maradi. Interview conducted on 29 March 2014 at the 17-portes shop in Maradi. 
As many cases across the Muslim world show, adopting social means to promote a discourse and build a community is not the preserve of Izala. ${ }^{18}$ On the contrary, the Middle East, Pakistan, and Indonesia are replete with initiatives that use social actions, education, and health for the most part to secure a presence in communities and influence religious discourses and practices. 'Wherever we organize the wa'azin kasa, we try to achieve something, ${ }^{19}$ said Alfa Issa, a member of the organizing committee of Maradi's wa'azin kasa.

However, in Maradi, and wherever this practice has spread today, the insistence on social action came only in the second phase of the development of wa'azin kasa. In the beginning (i.e. in the 1990s), wa'azin kasa were mainly intended to promote Izala's anti-Sufi stance and to give this movement a visibility beyond the urban centres where it tended to be confined. Spreading to rural areas very quickly became a major objective for the Izala movement and its preaching practices. In Nigeria, for example, the regional or even international wa'azin kasa led also to wa'azin jaha, which take place on a more local level. By adding a bottom-up approach to their expansion strategy, the promoters wanted to ensure that Izala's discourse had the local base it needed to anchor itself, consolidate, and spread. An interlocutor in Maradi explained: 'Because we were not accepted in the big cities, we spent more time in the countryside where people welcomed us more easily. ${ }^{20}$

Through wa'azin kasa, promoters of the Salafi discourse invented itinerant preaching methods and practices that are at the core of the revolution that the regional Islamic sphere is now experiencing in general. By putting in place this strategy, they laid the groundwork for various dynamics whose consequences are yet to be grasped. This is important to note because, as a channel of the popularization of reformist ideas and values, wa'azin kasa has produced a key infrastructural base, alongside Quran reading centres, madrasa, and mosques, enabling Izala discourse to spread across Niger and Nigeria - and beyond, to Cameroon, Chad, Burkina Faso, and Côte d'Ivoire. Through this process, Izala gained a visibility and presence that it would otherwise not have had.

For Izala, wa'azin kasa served as a way to bring together a community that was primarily conceived of and projected beyond national borders. This can be observed particularly in the second phase of the development of the movement in Niger - that is, starting in the 2000s - when the association that represented the movement at the time (Adini Islam) split into two separate organizations (Sounaye 2009), each with the intention of expanding its network beyond Niger and Nigeria to Togo, Ghana, and even Côte d'Ivoire. This expansion beyond national borders

\footnotetext{
18 The Muslim Brotherhood in Egypt, Hezbollah in Lebanon, Hamas in the Gaza Strip, and also the Mouride Brotherhood in Senegal are famous examples of this practice.

19 Interview with Alfa Issa, 17-portes, Maradi, 29 March 2014.

20 Interview with Balla, Rimbo Station, Maradi, 28 March 2014.
} 
and the importance it had, again raised the question of the true meaning of the religious concept of wa'azin kasa.

Photo 3 Preachers during a wa'azin kasa in Maradi, South Niger. (Photo: Abdoulaye Sounaye)

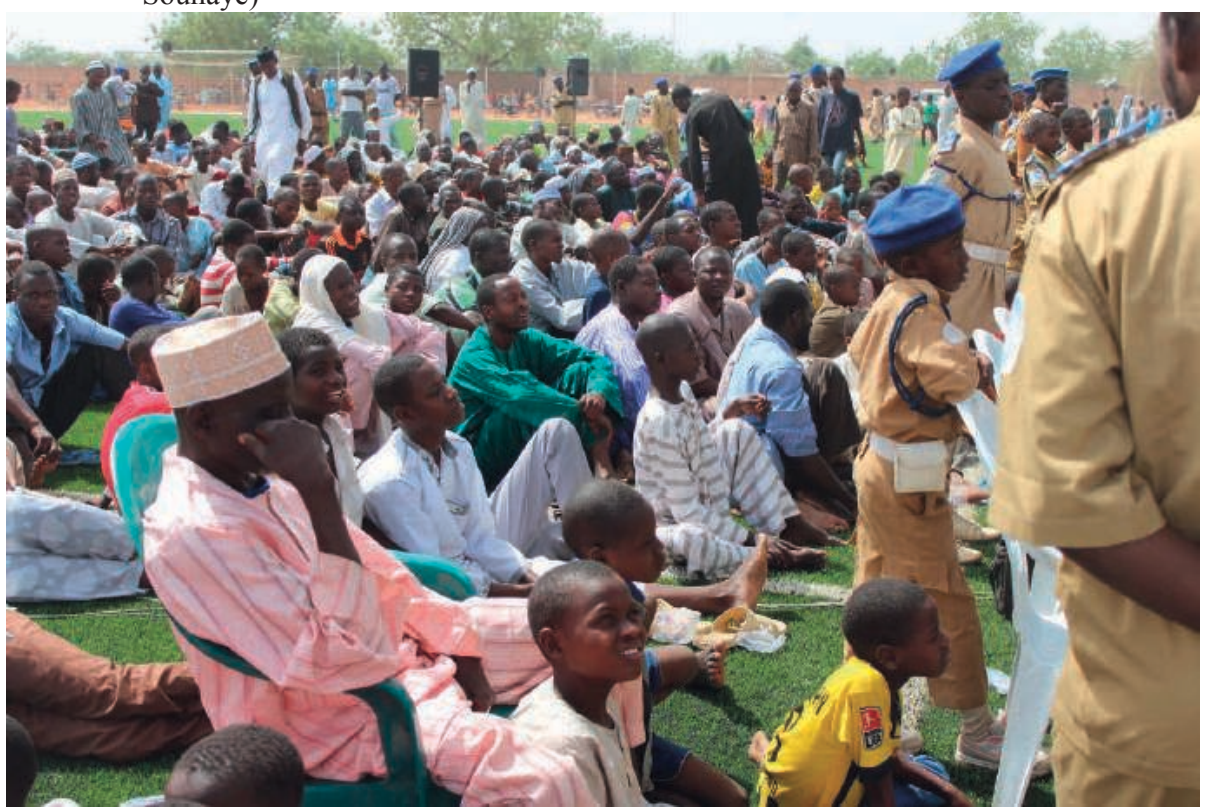

In fact, in the Hausa term ' $k a s a$ ', which literally means 'land' or 'soil', one can certainly see a reference to the modern state or a country - Niger or Nigeria, for example. But in the understanding and imagination of these religious actors, kasa is actually more about a land of Islam than a postcolonial territorial entity. This land of Islam, according to these actors, should 'correct' its practices and align with an orthopraxy that primarily looks up to the Prophet Muhammad and his companions and the all Salaf, the two generations that followed them. The reinterpretation and at the same time the expansion of the concept of kasa are certainly what this religious practice has managed to introduce - an evolution that, as we can imagine, represents a real challenge for the state logic of control and management of the religious sphere of the two countries. ${ }^{21}$

In Niger, the wa'azin kasa are usually gatherings attended by preachers from the region. In Nigeria, however, they have somewhat lost this trait, because of the

21 Generally speaking, the question of wa'azi brings up the issue of relations between state logics and popular practices, a point that I do not develop, but which should be central when analysing religion in this cross-border context. 
autonomy of national religious actors, which has thus led to a double phenomenon of multiplication of the wa'azi and internal conflicts, especially within the Izala movement in Nigeria. ${ }^{22}$ On the other hand, as is the case with the wa'azin kasa of Maradi I discuss here, in Niger, these gatherings also welcome preachers from Ghana, Burkina Faso, Nigeria, Cameroon, and Chad, in addition to the participants from across Niger. Among the foreign participants, Nigerians were the most numerous. This was reflected in the number of Nigerian licence plates on vehicles, which, more than usual, had jammed the streets of the city, located only two hours by road from Kano, the main city in northern Nigeria. This also confirmed the reputation of Maradi, generally perceived as the most Nigerian of Nigérien cities. It is even nicknamed 'the capital of the $37^{\text {th }}$ Nigerian state', to illustrate the influence of northern Nigeria on the socio-economic life of Maradi.

\section{Wa'azi, wa'azin kasa, and the circulation of religious ideas}

As we have just seen, wa'azin kasa have become a well-established institution in the Salafi practices across the Niger-Nigeria border. To their anti-Sufi mission and da'wa (call to Islam), they add a ritual that brings communities together to celebrate and assert Salafi presence in the public sphere. Under this guise, they offer a social space and become the medium through which a revolutionary religious ideal and a moral and political order are popularized. Preaching in this context is not simply an opportunity to promote theological positions, political ideas, and views on society; it is the means through which proponents of Salafism were able to impose an understanding of Islam, critical of Sufi organizations and rejecting pre- or non-Islamic local cultural and religious practices ( $a$ l'adu). There is no indication that the Salafi are a demographic majority. Actually, whether they are or not does not matter. The fact is that since the $1990 \mathrm{~s}$, they seem to have become the most influential trend, especially if we consider how their activism has reshaped the norms of Islamic practices and social, political, and cultural dynamics across the two countries. Through a sustained activism, they succeeded in setting the terms of the religious debate, but they have also significantly influenced both the references and the content of the common good, thus assuming the role of political actors in the broadest possible sense. ${ }^{23}$

Upon a closer examination, this activism reveals two main characteristics : The revivification of the Prophet Muhammad's Sunnah, a discourse that has taken

22 But this does not mean that the wa'azin kasa that are held in Nigeria have become exclusive. On the contrary, at the Sokoto wa'azin kasa, held in November 2016, for example, eight countries from the sub-region were represented (Niger, Benin, Cameroon, Chad, Burkina Faso, Togo, Côte d'Ivoire, and Ghana).

23 There have been controversies surrounding polio vaccination and multiple politicizations of Islam in both countries (Sharianization, family code, etc.). 
various forms depending on the local context where it is expressed. With the Izala movement, for example, it was used as a justification for a preaching campaign that sought to rally urban centres and rural areas. A practice such as fita (or hita), which literally means 'going out' in Hausa, served as the framework for the implementation of this project. Supporting da'wa, fita was the means by which the promoters of this new order brought the 'words of salvation' to the villages and regions where they wanted Islamic practice to move away from polytheism (shirk), the influence of marabouts, and Sufism. Authentic Islam, that of the Qur'an and Sunnah, based on knowledge and therefore enlightened, should therefore replace that of custom and Sufism, portrayed as insufficient or even dangerous.

The idea of a corruption and even of the 'death of the Sunnah' (mutua Sunna) became an obsession for Izala activists and gradually spread, mobilizing groups committed to safeguarding Islamic authenticity and the restoration of a moral order they viewed as the only solution to the ills of their society. In their sermons, Izala preachers, for example, often used the metaphor of the 'death of the Sunnah' in contrast to the life or revival of the Sunnah (rayuwa Sunnah). The wa'azin kasa in Maradi was an occasion for several preachers to revisit this metaphor. For Sheikh Khalid, three conditions must be met for the revivification of the Sunnah: the elimination of the bid'a, the death of idolatry (kafirci), and the reaffirmation of the Sunnah (tab-batar da Sunnah). He adds that 'to succeed, preaching must insist on the wa'zi to convey and make understood the Sunnah of the Prophet [Muhammad] beyond Niger, in all of West Africa'. ${ }^{24}$ In fact, according to him, every good Muslim must emphasize four prayers:

'May Allah destroy the bid'a and those who practise it.'

'May Allah annihilate idolatry and those who practise it.'

'May Allah strengthen the Sunnah.'

'May Allah bring down whoever wants to attack the Sunnah.'

These words resonate with many others often uttered by Izala personalities such as Sheikh Jafar and Kabiru Gombe, who constructed the Salafi reform the dichotomy of life and death. Today, more than a quarter of a century after this discourse emerged, it is apparent that the reformist agenda - the 'revivification of the Sunna' - has resulted in a process of social transformation with complex detours and appropriations, even violent ones, yet clearly defined.

24 Sheikh Khalid, organizer of wa'azin kasa, member of the Islamic organization Ihyau Sunna. Maradi, 29 March 2014. 
Photo 4 Public at a wa'azin kasa in Maradi (Photo: Abdoulaye Sounaye)

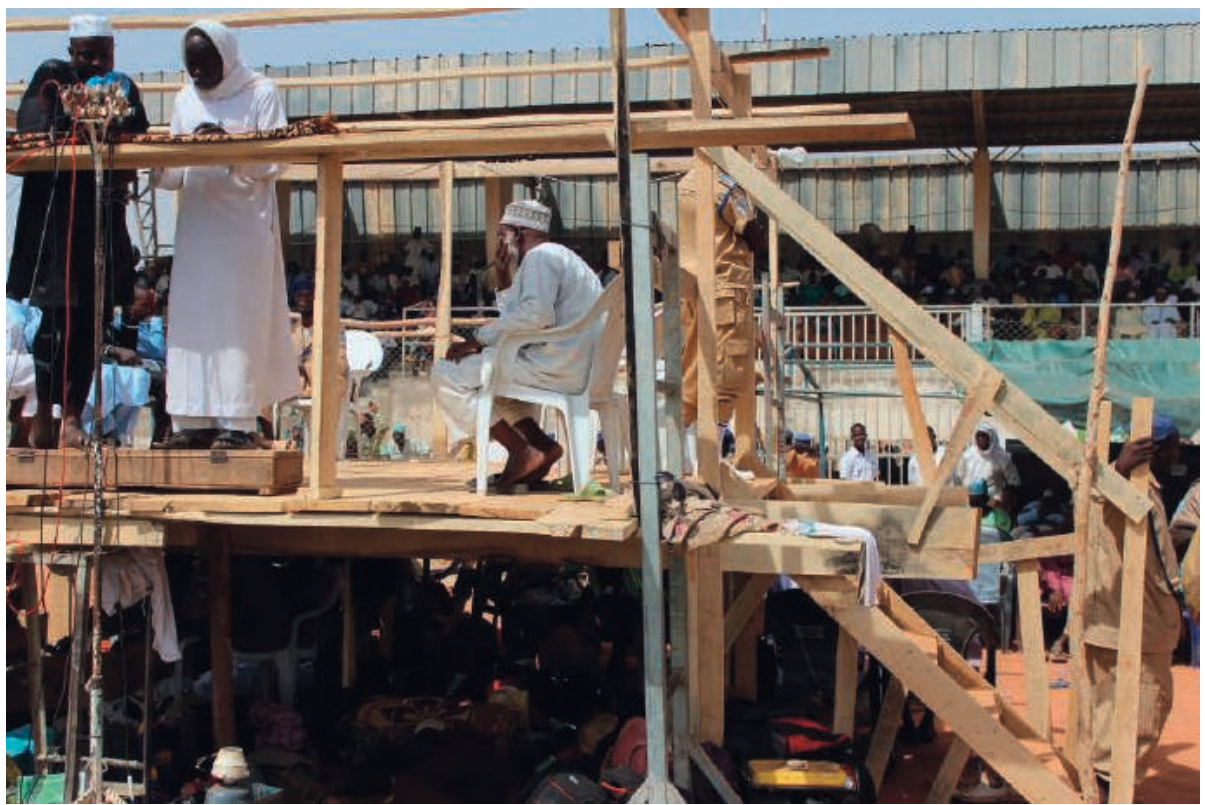

The second main characteristic of this activism is that it is a jihad of words, aimed at disseminating ideas and norms based on speech acts. Once again, wa' azi are described as a 'jihad of the mouth' (jihadin baki, ${ }^{25}$ in Hausa) that simply seeks to sustain the religious act of speaking, but especially the necessity of an activism based on widespread preaching. In this context, any space or platform can be used to popularize a discourse that found its model of religiosity in the salaf, the 'first who understood and practised the religion', according to Kabiru Gombe. The canon of interpretation and the norms and practices of the religion are then defined from this founding era and its figures (the 'pious predecessors'). The reference to the salaf thus denotes a particular relationship to the history of Islam, but especially an understanding that rejects innovation, seen primarily as corruption and misguidance. Jihadin baki is an oral act, which makes wa'azi its preferred space and the means to achieve its goal.

It should also be emphasized that wa'azi have not only served the circulation and the mediatisation of religious ideas and values; they have also generated many of these ideas and norms by inspiring appropriation and reinvention especially among the youth (Sounaye 2016). With the second generation of Izala preachers, for example, wa'azi took on new forms as well as more social and performative

25 Sheikh Khalid (d. 2008) in Niger and Sheikh Albani of Zaria, Nigeria (d. 2014) greatly emphasized this concept in their sermons. 
features (Sounaye 2017). It is true that religious content cannot be dissociated from performance, especially in a context of popular preaching. Both aspects are part of a religiosity that is reinvented in a genre that relies on the preacher's style and oratorical skills. In this specific case, creativity is also a mobilizing factor which, as seen in the Nigeria-Niger context, turns the preacher into a 'star' figure. One could easily illustrate this convergence of form and content in preaching, as aspects of mobilisation, by once again referring to the example of Sheikh Albani of Zaria or to Muhammad Yusuf, the ideologue and founder of Boko Haram.

In any case, it should be noted that the goal to revivify the Sunnah (raya Sunna, in Hausa) and promote a jihad based on Salafism (jihadin salafiya, in Hausa), ${ }^{26}$ which were popularized by preachers across the Niger-Nigeria border, have certainly benefitted from a regional integration that makes all sorts of mobility possible. This has affected not only goods but also people and their ideas, especially religious ones. Transport infrastructures have improved significantly in the last thirty years in the region, information and communication technologies have become increasingly democratized, while people have become more mobile and enterprising, implementing social engineering projects that enable them to build communities, but also to revitalise a trade in Islamic objects and products (medicines, clothes, books, CDs, etc.).

The dissemination of religious ideas is therefore supported by a variety of factors, language being an important one. The fact that Hausa is the main language of Islam in both countries has allowed for the transnationalization of wa'azin kasa and contributed the mobility of actors in the religious public space. This reality raises fears on the part of authorities, such as the governor of Maradi and the Sultan of Maradi, who have accused in several instances Nigerian preachers of propagating ideas that threaten peace and public order (Sounaye 2005). As a result, some of these preachers were forcibly sent back to the other side of the border, manu militari.

The mobility of Nigerian preachers has been restrained and controlled in Niger, but the distrust and resistance of the Nigérien authorities have not prevented the development of the Izala movement, a process that took place primarily through wa'azi campaigns and the support of a Muslim elite trained in Nigeria, especially in Jos. On their return to Niger, these Jos graduates proved to be effective relays of Izala discourse and practice, wherever they settled. The first Izala preachers in Maradi, for example, were trained in Jos, which they left with the plans to popularize Izala in Niger (Meunier 2000; Zakari 2008). The same can be said of

26 A key concept of Sheikh Albani's activism, which in many respects illustrates how he diverges from the Izala movement, both the Jos and Kaduna branches. All agree on the need for such work but disagree on the method and strategies which need to be implemented to make this jihad successful. 
Niamey, notably through the activism of the first overtly Izala Islamic organisation, Adini-Islam (Zakari 2007, 2010).

One often hears the participants of Wa'azin kasa say they are coming to hear the words of Allah and to learn how to better follow the teachings of the Quran and the Sunnah. Of course, this is part of a religious agenda, in the sense that it serves a transformation agenda of the individual and the community. That being said, beyond its ethical and moral - and therefore political - intentions, a wa 'azin kasa is also an economic space, where people meet and trade. This dimension is illustrated by many of the petty-trading activities that develop onsite, from the sale of water to the burning of CDs of the star preachers. These commercial aspects thus remind us of the economic aspect of wa'azin kasa, which in certain contexts is reason enough to participate.

An economy has therefore developed in the wake of a transnational Salafi discourse that advocates changes in behaviour, attitude, and practice. This again shows that the reformist discourse introduced by Izala goes beyond theological principles and assertions. By conveying ideas and values, it has also given rise to an economy initially structured around the consumption of anti-Sufi speech, and then around specific products and services. At the Maradi wa'azin kasa, this aspect was particularly apparent through the hundreds of merchants gathered for the occasion to sell their paraphernalia: hijab, dates, uniforms, medicines, books, etc. Similar to a fair, the guests of the stadium of Maradi where the event was held, were welcomed by the cacophony of the competing loud speakers set on the different stands where CDs and DVDs of recorded sermons were being sold. For 10,000 CFA (20\$), one could buy a 3GB USB flash drive containing sermons of the most popular preachers in the region. If anything, this highlights the intricate relationship between the Salafi ethic of moral transformation and the material and financial values that shape their cross-border activities.

\section{Conclusion}

The Izala movement and the competition it led to in the religious sphere contributed greatly to the popularization of wa'azi as a performance. Already an important element in the modes of expression of Islam, like tafsir, kuthba, and fatwa, wa'azi gained even more significance in the last three decades, adding to the dynamism and the presence of Islam in the public sphere. Wa'azi served Izala activism, but they have equally fed on it, notably through the campaigns for the popularization of the Sunnah, for which wa'azin kasa became a privileged space. While wa'azi helped popularize Salafi doctrine, they also contributed to new sociabilities, particularly the creation of Salafi communities, the restructuring of the religious sphere and the revitalization of a transnational religious sphere. A 
marker of the vitality of this sphere, wa' azi offered a stage where individual figures clashed and Islamic trends, groups and asscoiations fragmented. Indeed, wa'azi carry that feature beyond the Nigérien-Nigerian context, into much of West Africa.

In other words, if wa'azi have acquired the status and popularity they have today, it is precisely because they are part of the practices and serve as the tools of an activism that emerged at the crossroads of a religious reform project, the making of a new politico-moral order, and the socio-religious contestations characteristic of Islam in the last three decades. These practices offered a particular Islamic trend and specific figures the opportunity of a discursive presence in everyday life. As a vehicle for the propagation of anti-Sufism, for example, wa'azi served the interests of Izala in their fight against everything they saw as a deviation from authentic Islam. By taking on this role, wa'azi became one of the main stages of sociopolitical contestation and expression of dissent.

In fact, if we were to critically examine these contestations and the forms they take, we would certainly see the significant role sermons played in making violence, but also peaceful exhortation two means of politico-religious struggle most of the Sahel region experiences today. Most of the time, preaching eludes the regulation and control of state authorities - now that the religious sphere has become accessible to almost everyone - and especially as it has become a political act and a way of establishing authority. Charismatic Salafi preachers such as Sheikh Jafar, Sheikh Albani, Abubakar Gero, and Muhammad Yusuf illustrate this process of rebuilding religious hierarchies and establishing new forms of authority. This development is nothing less than a revolution.

\section{References}

ANONYMOUS (2012), 'The popular discourses of Salafi radicalism and Salafi counter-radicalism in Nigeria: A case study of Boko Haram', Journal of Religion in Africa 42(2): 118-44. doi:10.1163/15700666-12341224.

APARD, ElODIE (2016), 'Les mots de Boko Haram', Afrique contemporaine, no. 255 (May): 4374.

Berkey, Jonathan (2001), Popular Preaching and Religious Authority in the Medieval Islamic Near East. Seattle: University of Washington Press.

Brigaglia, Andrea (2007), 'The Radio Kaduna Tafsir (1978-1992) and the construction of public images of Muslim scholars in the Nigerian', Journal for Islamic Studies 27: 173-210.

BRIGAglia, ANDREA (2012), 'A contribution to the history of the Wahhabi da'wa in West Africa: The career and the murder of Shaykh Ja'far Mahmoud Adam (Daura, ca. 1961/1962-Kano 2007)', Islamic Africa 3(1): 1-23. doi:10.5192/21540993030101.

DeWIERE, REMI. 2017. Du lac Tchad à la Mecque, Le sultanat du Borno et son monde (XVIe XVIIe siècle). Paris: Editions de la Sorbonne. 
Eickelman, Dale F. \& Jon W. Anderson (2003), New Media in the Muslim World: The Emerging Public Sphere. Édition: 2nd revised edition. Bloomington. In: Indiana University Press.

FilAKOtA, RichaRD (2009), Le renouveau islamique en Afrique noire: L'exemple de la Centrafrique. Paris: L'Harmattan.

FOURCHARD, LAURENT (2005), Entreprises religieuses transnationales en Afrique de l'Ouest. Paris: Ibadan: Karthala.

GomeZ-Perez, Muriel (2005), L'islam politique au sud du Sahara: Identités discours et enjeux. Paris: Karthala.

Gomez-Perez, Muriel, Marie-Nathalie LeBlanc \& Mathias Savadogo (2009), 'Young men and Islam in the 1990s: Rethinking an intergenerational perspective', Journal of Religion in Africa 39(2): 186-218. doi:10.1163/157006609X436021.

Gomez-Perez, Muriel \& Frederick MAdore (2013), 'Prêcheurs(ses) musulman(e)s et stratégies de communication au Burkina Faso depuis 1990: Des processus différentiés de conversion interne', Théologiques 21(2): 121. doi:10.7202/1028465ar.

HAMANI, DJIBO (2007), L'Islam au Soudan Central: Histoire de l'Islam au Niger du VIIe au XIXe siècle. Paris: L'Harmattan.

Heiss, Jan PAtrick (2015), Musa: An Essay. 1 edition. Berlin: Duncker \& Humblot.

HigAZI, ADAM (2015), "Mobilisation into and against Boko Haram in North-East Nigeria." Collective Mobilisations in Africa / Mobilisations Collectives En Afrique, pp. 305-58. Leiden : Brill.

Holder, GiLles (2009), L'Islam, nouvel espace public en Afrique. Paris: Karthala.

JONES, LINDA G. (2010), 'Prophetic performances: Reproducing the charisma of the Prophet in medieval Islamic preaching', in Charisma and Religious Authority 4:19-47. Europa Sacra 4. Brepols Publishers. http://www.brepolsonline.net/doi/10.1484/M.ES-EB.3.3332.

Kane, Ousmane (1997), 'Un pluralisme en quete de democratie', in François Constantin \& Christian Coulon, eds, Religion et Transition Démocratique En Afrique, pp. 51-79. Paris: Khartala.

Kane, Ousmane (2003), Muslim Modernity in Postcolonial Nigeria: A Study of the Society for the Removal and Reinstatement of Tradition. Boston, MA: Brill Academic Pub.

Kendhammer, Brandon (2016), Muslims Talking Politics: Framing Islam, Democracy, and Law in Northern Nigeria. University of Chicago Press.

LOIMEIER, ROMAn (1997), Islamic Reform and Political Change in Northern Nigeria. Evanston, Ill: Northwestern University Press.

LOIMEIER, ROMAN (2006), 'Translocal networks of saints and the negotiation of religious disputes in local contexts', Archives de Sciences Sociales Des Religions, no. 135 (September): 17-32. doi:10.4000/assr.3687.

LOIMEIER, ROMAN (2012), 'Boko Haram: The development of a militant religious movement in Nigeria', Africa Spectrum 47(2-3): 137-55.

LOIMEIER, RomAn (2013), Muslim Societies in Africa: A Historical Anthropology. Bloomington: Indiana University Press.

LOIMEIER, ROMAN (2016), Islamic Reform in Twentieth-Century Africa. 1st edition. Edinburgh: Edinburgh University Press.

MEUNIER, OLIVIER (2000), Les routes de l'Islam: Anthropologie politique de l'islamisation de l'Afrique de l'Ouest en général et du pays Hawsa en particulier du VIIIè au XIXè siècle. Paris: Editions L'Harmattan.

Miles, William F.S. (1994), Hausaland Divided: Colonialism and Independence in Nigeria and Niger. Ithaca: Cornell University Press. 
MirAn, MARIE (2006), Islam, histoire et modernité en Côte d'Ivoire. Paris: Karthala.

Nicolas, GuY (1975), Dynamique sociale et appréhension du monde au sein d'une société Hausa / Guy Nicolas. Travaux et mémoires de 1'Institut d'ethnologie; 78. Paris: Institut d'ethnologie.

Nicolas, GuY (1981), Dynamique de l'Islam au Sud du Sahara / Guy Nicolas. Paris: Publications orientalistes de France.

Nicolas, GuY (1986), Don rituel et échange marchand dans une société sahélienne / Guy Nicolas. Mémoires de l'Institut d'Ethnologie, 25. Paris: Institut d'Ethnologie.

Nouhou, Alhadj-Bouba (2005), Islam et politique au Nigeria: Genèse et évolution de la chari'a. Paris: Karthala.

OtAyeK, Rene (2000), Le Radicalisme islamique au sud du Sahara. Paris : Talence: Karthala.

Saint-Lary, Maud (2012), 'Du wahhabisme aux reformismes generiques: Renouveau islamique et brouillage des identites musulmanes À Ouagadougou.' Cahiers d'Etudes Africaines 2(206207): 449-70.

Salvatore, A. \& Eickelman, D.F. (2004), Public Islam and the Common Good. Leiden; Boston: Brill.

Savadogo, Mathias \& Gomez-Perez, Muriel (2011), 'La médiatisation des prêches et ses enjeux. Regards croisés sur la situation à Abidjan et à Ouagadougou', ethnographiques.org 22 (May). http://www.ethnographiques.org/2011/Savadogo,Gomez-Perez.

Schulz, Dorothea E. (2011), Muslims and New Media in West Africa: Pathways to God. Bloomington: Indiana University Press.

SOUley, HASSANE (2005), 'Les nouvelles élites islamiques du Niger et du Nigéria du nord: Itinéraires et predication fondatrices'. In: Laurent Fourchard, André Mary \& René Otayek, eds, Entreprises Religieuses Transnationales en Afrique de l'Ouest, pp. 350-73. Paris: Karthala.

Sounaye, Abdoulaye (2005), 'Les politiques de l'islam dans l'ere de la democratisation de 1991 À 2002', in Muriel Perez-Gomez, L'islam Politique au Sud Du Sahara, pp. 503-25. Paris: Karthala.

SOUNAYE, ABDOUlAYE (2009), 'Izala au Niger: Une alternative de communaute religieuse'. In: Laurent Fourchard, Odile Georg \& Muriel Gomez-Perez, Les Lieux de Sociabilité Urbaine Dans La Longue Durée En Afrique, pp. 481-500. Paris: L'Harmattan.

Sounaye, ABDoulaye (2011a), "La "discothèque" islamique: CD et DVD au cœur de la réislamisation Nigérienne.' Ethnographiques.org. http://www.ethnographiques.org/2011/sounaye.

SounAYe, ABDOUlaye (2011b), 'Doing development the Islamic way in contemporary Niger'. Bulletin de l'APAD, no. 33 (August). http://apad.revues.org/4084.

Sounaye, ABdoulaye (2012a), 'Heirs of the Sheikh: Izala and its appropriation of Usman Dan Fodio in Niger', Cahiers d'Etudes Africaines 206/207: 427-47.

Sounaye, ABdoulaye (2012b), 'Les clubs des jeunes musulmans du Niger: Un espace intergénérationnel', in Muriel Gomez-Perez \& Marie-Nathalie LeBlanc, L'Afrique Des Générations. Entre Tensions et Négociations, pp. 166-217. Paris: Karthala.

SounAYE, ABDOUlaye (2012c), 'Recognizing religion in development processes in SubSaharan Africa: The Case of Niger', Ciência \& Trópico 36(1): 45-72.

Sounaye, Abdoulaye (2013), 'Alarama is all at once: Preacher, media savvy and religious entrepreneur.' Journal of African Cultural Studies 25(1): 88-102.

Sounaye, Abdoulaye (2014), 'Mobile Sunna: Islam, small media and community', Social Compass 61(1): 21-29. 
Sounaye, ABdoulaye (2015), 'Irwo Sunnance Yan-No! 1: Youth claiming, contesting and transforming Salafism', Islamic Africa 6: 82-108. doi:10.1163/21540993-00602006.

SounAYE, ABDOUlAYE (2016), 'Let's do good for Islam: Two Muslim entrepreneurs in Niamey, Niger', in Cultural Entrepreneurship in Africa, pp. 37-57. New York, NY: Routledge.

Talmon-Heller, Daniella (2008). Islamic Piety in Medieval Syria: Mosques, Cemeteries and Sermons Under the Zangids and Ayyubids. Leiden; Boston: Brill Academic Pub.

Thurston, Alexander (2016a), “The disease is unbelief”: Boko Haram's religious and political worldview'. Brookings. January 14.

https://www.brookings.edu/research/the-disease-is-unbelief-boko-harams-religious-andpolitical-worldview/.

Thurston, AleXAnder (2016b). Salafism in Nigeria: Islam, Preaching, and Politics. Cambridge: Cambridge University Press.

UMAR, MUHAMMAD (1993), 'Changing Islamic identity in Nigeria from the 1960s to the 1980s: From Sufism to anti-Sufism', in Muslim Identity and Social Change in Sub-Saharan Africa. Brenner, L. London: Hurst.

UMAR, MUHAMmAD SANI (2006), Islam and Colonialism: Intellectual Responses of Muslims of Northern Nigeria to British Colonial Rule. Leiden: Brill.

YAHYA, MARYAM (2006), 'Polio vaccines - difficult to swallow: The story of a controversy in northern Nigeria'. Institute of Development Studies / Working Paper 261.

ZAKARI, MAÏKOREMA (2009), L'Islam dans l'espace nigérien: Tome 1, Des origines (VIIe siècle) à 1960. Paris: L'Harmattan. 


\title{
'Rapping Islam': The Nigérien music scene and the challenges of religious reformism
}

\author{
Élodie Apard
}

In Niger, since the democratic opening of the 1990s and the subsequent religious liberalism, the set of codes and rules defined by the Izala movement has competed with existing normative systems, which had until then been largely dominated by Sufi doctrines. Today, after thirty years of ideological opposition - sometimes violent - the Izala discourse has fully integrated into the Nigérien Islamic landscape, significantly changing the way people think and live Islam, thus normalizing the process of 're-Islamization' in Niger. ${ }^{1}$

The effects of the renewal of religious norms can be observed in everyday life - for example, through the transformation of liturgical practices. But they can also be measured through the analysis of cultural developments, and in particular at the level of artistic production. Among the creative spaces in which the impact of the Izala discourse is felt, 'modern' music is undoubtedly a domain that clearly reveals the dichotomy between what the Izala ideology defines as 'hallal' and 'haram', between what is considered acceptable and unacceptable. Over the past two decades, the Nigérien music scene has indeed been the theatre of opposition between artists and preachers, who have said they were acting, some for the promotion of Nigérien culture, others for the defence of the moral order. In addition, the hip-hop movement in Niger - which flourished in the early 2000s and was also highly criticized by religious leaders - has been a laboratory of experiences in which young artists, who wanted to pursue their careers while remaining 'good' Muslims, have put in place various coping strategies.

The Nigérien musical sphere is therefore a place where popular expectations in terms of entertainment, professionalization requirements, and religious constraints converge, as well as a place that has been considerably transformed by the rise of

See Abdoulaye Sounaye (2016), Islam and Modernity. Contribution à l'analyse de la ré-islamisation au Niger, Paris, Harmattant. 
the reformist movements. ${ }^{2}$ Studying the effects of the transmission of Izala standards on musical creation and production reveals the negotiation processes and compromises adopted by artists in the face of renewed religious directives. It also highlights the distinction between religious identity and religiosity among musicians, ${ }^{3}$ for whom artistic performance and spiritual quest are sometimes linked, sometimes in total opposition.

Based on the individual career paths of several Nigérien musicians, the objective here is to understand, in the light of professional and artistic choices made in a disputed religious space, how these re-orientations reflect broader transformations within the Nigérien society and what they reveal, in particular, about transnational Islamic dynamics fostered by reformists.

Map 5 Geographical distribution of Apard's fieldworks

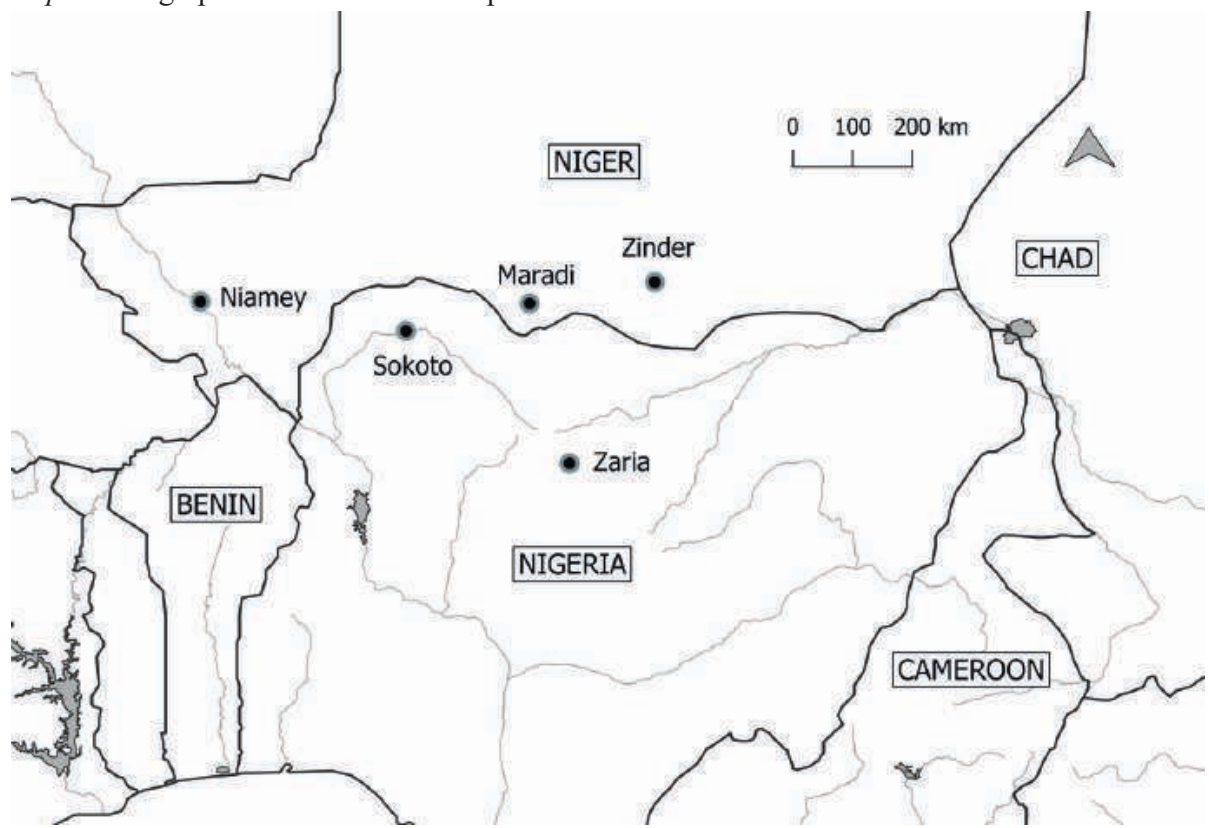

2 The fashion world has also been confronted with the coexistence of these contradictory dynamics. When in 1998 the designer Alphadi created the Festival International de la Mode Africaine (FIMA), he made Niger an international fashion hub, considerably increasing its visibility, but the organization of fashion shows provoked the anger of some religious groups - including Izala preachers - who regularly mobilized to prevent activities. The 2000 edition of the festival was marked by particularly violent riots, at the end of which several Islamic organizations were banned by the government. In 2018, FIMA was organized in Morocco.

3 Distinction established by Adeline Masquelier in her work on the relationship between youth and Islam in Dogondoutchi: 'Securing futures: Youth, generation and Muslim identities in Niger'. In: Asef Bayat \& Linda Herrera (2010), Being Young and Muslim. New Politics in the Global South and North, Oxford University Press, pp. 225-40. 


\section{The transnationalization of Izala dogma}

Originating from northern Nigeria, the Izala movement developed in the 1970s under the influence of Abubakar Gumi, former Grand Kadi of the Northern Region and promoter of the Salafi doctrine, inspired by the Saudi Wahhabi model. ${ }^{4}$ The Jama'atu Izalatul Bid'a wa Iqamatu Sunnah movement ${ }^{5}$ ('Izala' being the diminutive name) has as mission to reform an Islam perverted by 'blameworthy innovations' (bid'a in Arabic) not in conformity with the Prophetic tradition, including those introduced into Nigeria by Sufi brotherhoods such as the Tidjaniyya and Qadiriyya.

Izala appeared in Niger in the early 1990s, as a result of the democratization process and the policy of openness enjoyed by religious associations. Created in 1974, the Association Islamique du Niger (AIN) was until then the only authorized structure, entrusted by the state with the management of the country's religious affairs; but with the end of the state monopoly, many groups previously forced into clandestinity were formed as religious associations. This period of openness was particularly beneficial to the Izala trend, which first emerged in the major urban centres close to Nigeria. ${ }^{6}$

While the term Izala is often used by critics of the movement, the faithful prefer the expression 'Ahlus Sunnah', ${ }^{7}$ in reference to the Prophetic tradition which, together with a series of texts interpreted and re-appropriated, constitutes the 'Salafi canon' on the basis of which the Izala ideology has been defined and disseminated. ${ }^{8}$ This gives rise to a set of norms, considered valid and universal, allowing the 'Izala subject' to define himself - in opposition to Sufism - as the guarantor of an authentic Islamic order and as the main actor in the process of 'reIslamization'. ${ }^{9}$ Since truth can emanate only from the Prophetic tradition, any idea or practice that deviates from it must, according to the reformist principles, be identified and rectified. ${ }^{10}$

If the Izala ideology does not reject the idea of democracy and allows itself to be integrated into a secular framework, the objective remains, however, to

4 Roman Loimeier (1997), Islamic Reform and Political Change in Northern Nigeria, Northwestern University Press, pp. 50-52.

5 Movement for the Suppression of Innovation and the Establishment of Sunnah.

6 See Emmanuel Grégoire (1993), 'Islam and identity of merchants in Maradi (Niger)'. In: Louis Brenner, ed., Muslim Identity and Social Change in Sub-Saharan Africa, London, Hurst \& Company, pp. 10615 .

7 'The people of the Sunnah'

8 Alexander Thurston (2016), Salafism in Nigeria. Islam, Preaching and Politics, Cambridge University Press, p. 1.

9 Abdoulaye Sounaye (2016), Islam and Modernity. Contribution à l'analyse de la ré-islamisation au Niger, Paris, Harmattant, pp. 113-16.

10 Abdoulaye Sounaye (2009), 'Izala au Niger: une alternative de communauté religieuse'. In: L. Fourchard, O. Goerg \& M. Gomez-Perez, eds, Les lieux de sociabilité urbaine dans la longue durée en Afrique, Paris, Harmattan, pp. 481-500. 
transform society in depth and from inside, so that the state itself guarantees respect for the rules and precepts enacted, or even enforces them. The agenda of the Izala movement is therefore not strictly religious, and it aims, beyond Islamic reform, at a reform of the social order. ${ }^{11}$

Like other reformist movements, Izala is characterized by an active proselytism and a multifaceted presence in the public space. ${ }^{12}$ Firmly established and institutionalized in Nigeria, it has developed effective communication tools, enabling it to reach far beyond the country's borders. It is primarily the sermons that, in the form of public gatherings or on cassettes, CDs, and DVDs, have ensured the dissemination and popularization of the Izala discourse.

Initially supported by traders in the Maradi Region, ${ }^{13}$ the establishment of Izala in Niger became visible during the 1990s, with the creation of organizations which were responsible for promoting the ideology of the movement and also distinguished themselves in non-religious activities: development, awarenessraising, and professional training activities. ${ }^{14}$ This is the case with the main Izala associations in Niger, such as Kitab Wa Sunnah and Iya'u Sunnah.

The structuring of Izala in Niger also involves private radio and television stations, which have helped to broaden the audience of preachers. The example of Bonferey radio television, ${ }^{15}$ among others, particularly illustrates the link that has been established between the media and religious reformers in Niger. Founded and financed by Himadou Hamani 'Sirignere', a wealthy businessman from Kollo region, Bonferey radio television has been promoting Izala's ideas, values, and principles since its creation. Unlike other stations characterized by the heterogeneity of their programmes, Bonferey does not broadcast any music programmes or Brazilian TV shows. South American soap operas, which are very popular in West Africa, have often been criticized by religious leaders for their staging of romance, considered as not adapted to Islamic culture. ${ }^{16}$ Music is banned by the Salafi dogma, which considers the use of instruments and rhythm as satanic diversions that keep the faithful away from devotion; the songs or video clips of Nigérien and international musicians are therefore also deprived of airtime on Bonferey. However, anasheed - a capella religious songs - are broadcast

11 See Ousmane Kane (1998), 'Le réformisme musulman au Nigeria du Nord'. In: Ousmane Kane, ed., Islam and Islamism in south of the Sahara, Karthala Editions, pp. 117-35.

12 On Pentecostal proselytism, see Olufunke Adeboye (2012), 'A church in a cinema hall. Pentacostal appropriation of public space in Nigeria', Journal of Religion in Africa 42(2): 145-71.

13 Olivier Meunier (2002), 'Développement du wahhabisme au Niger: analyse socio-historique de la diffusion du mouvement Izala dans la ville de Maradi', Revue africaine de recherche en éducation, 'l'éducation dans la société africaine', $\mathrm{n}^{\circ} 1$, pp. 121-52.

14 Hassane Mouley, Marthe Diarra \& Oumarou Makama (2005), Etude sur l'Islam au Niger, Danida, Niamey, p. 66.

15 Radio station created in 2001, television channel created in 2007.

16 Kadidia Touré (2006), 'Telenovelas et dynamiques identitaires à Bouaké et Bamako'. In: Jean-François Werner, ed., Médias visuels et femmes en Afrique de l'Ouest, Paris, L'Harmattan, pp. 195-242. 
regularly and even constitute an important part of the programmes during the month of Ramadan. For Bonferey's director, the programmes, essentially made up of preaching, correspond 'to the founder's aspirations' but also 'to the reality of the country and the public's demand'. ${ }^{17}$ While the popularity of religious programmes can indeed be confirmed by a quick review of the programme schedules of competing radio and television stations, it remains difficult to determine whether this specifically concerns 'Izala content'. On Bonferey, sermons are broadcast in the different languages spoken in Niger - Hausa, Zarma, Peul, French, but sometimes also Arabic and English - and therefore reach a wide audience. With airtime priority being given to Izala preachers, they benefit from a large audience. Moreover, Bonferey is not the only actor involved in the popularization of the Izala discourse, which is also broadcast by other private stations, such as Dounia radio television. ${ }^{18}$ However, whether the place of Izala preaching on Niger's radio and television stations is due to the appetite of the Nigérien public or to a clever communication strategy, the result is the same: the reformist discourse has become familiar. Fully integrated into the religious, social, and media landscape of Niger, it is part of the habits of an audience that, even when it has not adopted it, has assimilated it.

Northern Nigerian preachers have played and continue to play a major role in the dissemination and popularization of this discourse, not only on radio and television stations, but also through recorded sermons sold in markets and specialized shops - in the form of CDs, DVDs, or USB sticks ${ }^{19}$ - and through public wa'azi, the large preaching gatherings, the most important of which is the wa'azin kasa, an event that usually lasts several days. ${ }^{20}$ Many wa'azi organized in Niger's main cities are performed by the great figures of Nigerian preaching, whose filmed sermons, widely consumed in Niger, have ensured their fame. Over the past ten years, one has seen the rise of Nigérien preachers, such as Sheikh Falalu Tassiou, who have also become very popular and ensure continuity in the dissemination of the Izala message, but the stars of the genre remain the Nigerian sheikhs. Mahmud Adam Ja'afar and Albani Zaria, both murdered by Boko Haram, are still widely listened to in Niger, as is Sheikh Issa Pantami, who, in 2005, challenged Mohammed Yusuf in a television debate that became famous. Among the Nigerian Izala - or Ahlus Sunnah - who are leading sales in Niger, Sheikh Kabiru Gombe enjoys great prominence, which is reflected both in the commercial

17 Interview with the Director of Bonferey radio television, conducted in Niamey on 23 February 2015.

18 As preaching is systematically part of radio and television programmes in Niger, all channels and stations have more or less contributed to broadcasting the Izala discourse, including 'liberal' media such as the Alternative radio, which also offers airtime to Izala preachers.

19 Sound content on CD media, preaching filmed on DVD and USB sticks; a large number of audio (usually in MP3 format) or video files can be loaded at once.

20 The place of the wa'azi in the emergence of a Nigérien-Nigerian religious sphere is discussed in this volume by Abdoulaye Sounaye. 
success of his filmed sermons and in the attendance systematically drawn by his participation in wa $^{\prime}$ azi. ${ }^{21}$

Photo 5 A DVD Shop in Niamey (Photo: Elodie Apard)

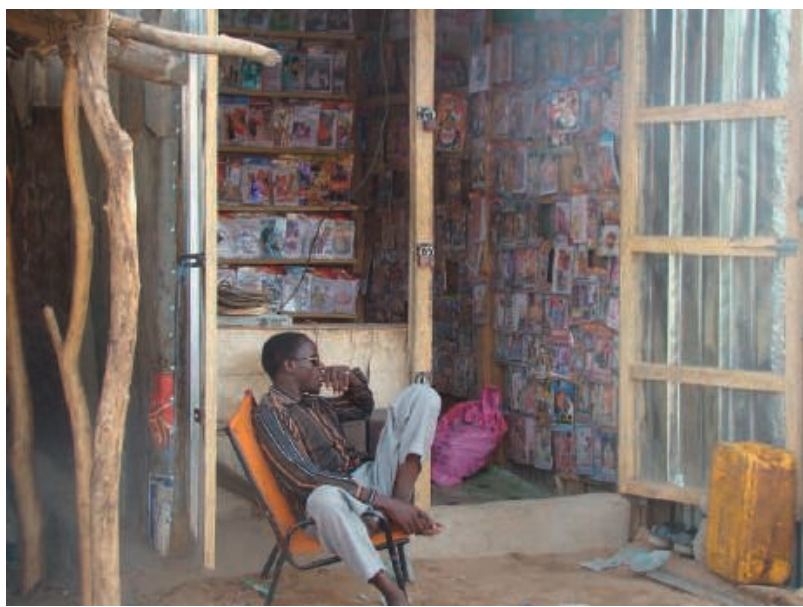

Photo 6 Islamic Sermons' DVD for sale in Niamey (Photo: Elodie Apard)

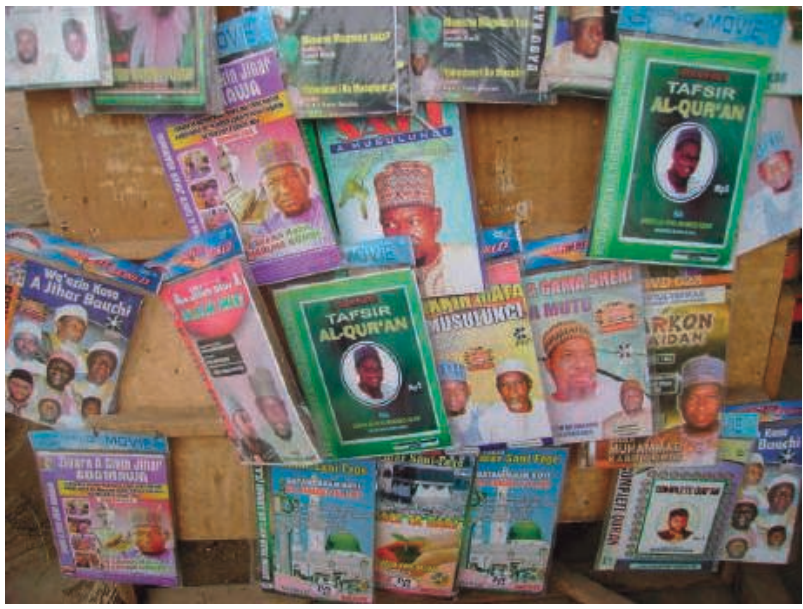

21 Another way to assess the popularity of preachers is to compare the number of views counted in the videos of their sermons posted on YouTube. Tassiou Falalu's videos are viewed, on average, between 1,000 and 5,000 times, while Kabiru Gombe's videos count, on average, between 60,000 and 200,000 views. While it has grown considerably in Niger, the audience for Nigerian preachers remains largely composed of the Nigerian public, which is proportionally about 10 times larger (190 million inhabitants in Nigeria compared with 21 million in Niger in 2018). 
Information collected from Islamic CD and DVD sellers in Niger reveals not only a market dominated by Ahlus Sunnah in general and the Nigerian sheikhs in particular, but also Nigeria's major role in the preaching industry. ${ }^{22}$ While Niger's production capacity has grown considerably over the past ten years, it remains relatively small-scale; ${ }^{23}$ it is still the studios and production houses in the major cities of northern Nigeria that supply the Nigérien market. In particular, Kaduna, a pioneer city in the spread of preaching, ${ }^{24}$ and Kano, the commercial capital of the north, ${ }^{25}$ occupy a central place in the regional circuits.

\section{Moral norms and social order}

The content of the sermons varies according to the context, the target audience, or the news, which is sometimes used as a basis for the development of an argument. However, the vast majority of Izala sermons devote significant time to criticizing Sufi movements, their methods, beliefs, and representatives. Whether it concerns prayer, modes of celebration, or the amount of the dowry, Sufi brotherhoods' practices are systematically rejected. The rules permitting the faithful to avoid making mistakes are then set out and justified using the texts and interpretations constituting the Izala dogma.

Each DVD is a compilation of several sermons, given by one or several different preachers. The packaging indicates the title of each 'album'; and while some titles are rather generic, ${ }^{26}$ others offer details on the content, as part of a commercial attractiveness strategy. ${ }^{27}$ The success of Izala sermons is partly based on their vehement character and the polemics they provoke, with the public sometimes seduced by the values promoted, sometimes simply curious about statements that directly challenge a formerly established religious and social order.

The (re)definition and defence of moral values occupy a central place in the Izala discourse, which, by establishing a very clear dichotomy between what is

22 Survey conducted between 2014 and 2016 among 40 DVD sellers in the Nigérien cities of Zinder, Maradi, Agadez, and Arlit. In each city, the same questionnaire was submitted to ten different sellers: who are the best sellers? What are the best-selling themes? Who are the rising figures and the losing preachers? What is the origin of the DVDs and the distribution method?

23 Abdoulaye Sounaye (2011), "La "discothèque" islamique: CD et DVD au coeur de la réislamisation nigérienne', Ethnographiques.org No. 22 (May), 'les Outils d'un islam en mutation. Réislamisation et moralisation au sud du Sahara'.

24 Andrea Brigaglia (2007), 'The Kaduna Radio Tafsir (1978-1992) and the construction of public images of Muslim scholars in the Nigerian media', Journal for Islamic Studies 27: 173-210.

25 Brian Larkin (2008), Signal and Noise: Media, Infrastructure, and Urban Culture in Nigeria, pp. 14870, Durham, Duke University Press.

26 They can indicate only the purpose of the sermon (e.g. 'Ramadan Tasfir') or the surah that is discussed (e.g. 'Al Baqara'), or bear the name of the event at which they took place (e.g. 'Waaz'in kasar Niger'). See some examples of wa'azi on DVD in the appendixes of this volume.

27 Since the beginning of the Boko Haram violence, for example, many DVDs of sermons capitalize on the debates generated by the presence of the jihadist group on the Nigerian Islamic scene. 
'Islamically correct' and what is not, between what is decency and what is perversion, offers the faithful the means to protect themselves against 'moral chaos'. ${ }^{28}$ The actions to be taken, in public and in private, are the subject of many sermons, especially for women, and are mainly centred on the body, modesty, and sexuality. These themes attract a lot of interest, and sermons about conjugal relationships, for example, are in high demand. ${ }^{29}$ However, in the arguments of many Izala preachers, women are considered not only as inciters to depravity but also, paradoxically, as more reasonable than men in the management and suppression of impulses; they are therefore attributed, in large part, the responsibility for preserving good morals.

During preaching sessions exclusively for women, the arguments in favour of their active involvement are widely developed. Abubakar Gero, a famous Izala preacher from Argungu, north-west Nigeria, regularly addresses these issues; in the DVD entitled Matan kwarai, Iyalin kwarai, ${ }^{30}$ which brings together several sermons dedicated to women, he presents reformism as an asset for the new generations:

Women who lived about fifty years ago did not have a good knowledge of Islam. Women then wore petticoats and short skirts. You can be proud to live in an era when Islam has evolved. You have to thank God for pulling you out of ignorance. ${ }^{31}$

He thus compares 'good' morality with the practices developed since the introduction of the Islamic reform, which have corrected the mistakes of the past. As holders of in-depth religious knowledge, acquired through a process of selftraining and 'conscientization' 32 guided by the Izala dogma, women integrate and then defend the moral values to which they have been sensitized. For example, by avoiding motorcycle taxis - a very economical, practical, and popular means of transport in Nigeria's major cities - they are unlikely to expose the parts of their bodies that are supposed to be covered, such as ankles or calves, or to have physical contact with a man who is not only outside the family circle but sometimes also non-Muslim. ${ }^{33}$

28 Abdoulaye Sounaye, Islam and Modernity. Contribution à l'analyse de la ré-islamisation au Niger, op. cit. p. 115.

29 According to the survey conducted between 2014 and 2016 among 40 DVD sellers in the Nigérien cities of Zinder, Maradi, Agadez, and Arlit.

30 Title in Hausa which can be translated into English as 'Good women, good family'.

31 Abubakar Gero, 'Matan kwarai, Iyalin Kwarai', Ramadan preaching held in Gwandu, Niger State, Nigeria, July 2012.

32 Abdoulaye Sounaye, Islam and Modernity. op. cit.

33 Abubakar Gero, 'Matan kwarai, Iyalin Kwarai', Ramadan preaching held in Gwandu, Niger State, Nigeria, July 2012. 
In Kano, the promotion of good morals is the objective set by the social and moral reorientation programme set up in 2004 by Governor Shekarau, which - by separating men and women in public transport and replacing motorcycle taxis with tricyles, in which passengers and drivers do not touch each other - echoes Izala's argument for re-moralizing society. This programme, named 'A daidaita sahu', ${ }^{34}$ by imposing new regulations on urban mobility has therefore had a direct impact on the transformation of public space. ${ }^{35}$ While illustrating the convergence of religious and political agendas, the example of $A$ daidaita sahu shows the level of mutual interpenetration and influence of religious, political, and social dynamics in a city such as Kano. ${ }^{36}$

However, the Izala discourse of re-moralization of society also concerns the cultural field, and music plays an important role, as do other forms of entertainment, which are also subject to precise rules. The practice and consumption of music is a major subject of disagreement with the Sufi brotherhoods, since, for the reformists, the introduction of musical instruments and rhythm in the praises given to the Prophet, for example, is part of the bid'a. They emphasize the ability of music to divert the faithful from their devotion to God and consider, for example, zikiri - a liturgical practice of chanting God's names or singing praises to the Prophet - as a perverted practice among the Sufis, who add music to it, sometimes even electronic music. In some contexts, such as in Mali, this practice has become more professional, giving rise to a new form of cultural production, reconciling Islam and popular music. ${ }^{37}$ This is an impossible compromise, according to the Izala dogma, since, as Sheikh Adam Ja'afar points out in one of his sermons, zikiri 'cannot be done in the crowd and cannot be done with music or dancing'. ${ }^{38}$ If the practice itself is not rejected, it must be characterized by the sobriety and restraint specific to the individual spiritual approach of the faithful Izala.

Another problem mentioned in the preaching about music concerns the behaviours that accompany it and supposedly encourage depravity. Abubakar Gero, for example, refers to the role of music in celebrations:

\footnotetext{
34 Hausa expression for the alignment of the faithful at the mosque during collective prayers.

35 See the E-papers produced as part of the Masterclass 'New Forms of Popular Transportation of Goods and Persons in Nigeria', organized by IFRA-Nigeria, Science Po Paris, and Columbia University from 2 to 7 July 2018 in Kano. http://www.ifra-nigeria.org/training/masterclasses/261-report-new-forms-ofpopular-transports-of-goods-and-persons-in-nigeria

36 Alexander Thurston (2014), 'Muslim politics and Sharia in Kano State, northern Nigeria', African Affairs 114(454): 28-51.

37 Pierre Prud'homme (2014), 'Les griots d'Allah ou l'émergence d'une musique religieuse populaire', Le Mali Contemporain, Marseille, IRD Editions, pp. 317-32.

38 Mahmud Adam Ja'afar, Tasfirin Suratul Nisa, Vol. 1, Tafsir of Ramadan 2005, Kano.
} 
The festivities that accompany naming ceremonies and weddings are practices from the time of ignorance. Bringing in griots and dancing are negative practices. Marriages in the time of ignorance are ten days of festivities, music, dance, and expenses. The complicity between the bride and the musicians can lead to obscene gestures. ${ }^{39}$

As questions of modesty and morality are at stake, women's responsibility is once again invoked, both in the persistence of bad practices and in their necessary eradication.

Previously, young girls before getting married listened to music like Michael Jackson. These are Western practices; it's not good. But Michael Jackson's time is over. Now the time of Islam has come. Dan Ibro and dandalin soyeya's CDs should be discarded. Quranic schools must be filled with women. The objective, the mission of women now, is total submission to God. Those who follow the good teachings and practices, God reserves Paradise for them. ${ }^{40}$

By simultaneously condemning Michael Jackson, Dan Ibro - the famous Nigerian comedian - and the dandalin soyeya musical style, Gero rejects very different forms of entertainment. ${ }^{41}$ But what American pop music, Kannywood's burlesque comedies, ${ }^{42}$ and the Hausa love songs characteristic of the dandalin soyeya have in common is the fact that they are extremely popular and, therefore, particularly likely to compromise total devotion to God. However, it is these two negative aspects of music that are alternately evoked by the Izala preachers: both entertainment that distances itself from God; and a way of expressing vulgarity, which leads to indecent behaviour. Questions linked to entertainment and music's production and consumption are therefore at the heart of the re-Islamization issues and challenges in northern Nigeria - and, because of the transnationalization of discourses, also in Niger.

39 Abubakar Gero, 'Matan kwarai, Iyalin Kwarai', Ramadan preaching held in Gwandu, Niger State, Nigeria, July 2012.

40 Idem.

41 Dandali soyeya (lit. 'platform of love') is a very popular Hausa cultural movement (musical, literary, and video production), inspired by Indian musicals. The songs and videos of dandali soyeya celebrate love.

42 Name given to the north Nigerian film industry, based in Kano, of which Dan Ibro was one of the main figures. The Hausa cinema community has been regularly targeted by reformist preachers. See Carmen McCain (2013), 'Nollywood, Kannywood and a decade of Hausa film censorship in Nigeria'. In: Daniel Biltereyst \& Roel Winkel Vande, eds, Silencing Cinema: Film Censorship around the World, London, Palgrave MacMillan, pp. 223-40. 


\section{Religious norms and the Nigérien music scene: Contestation, adaptation, and re-appropriation}

While the impact of religious discourse on cultural life and artistic production in northern Nigeria has been the subject of academic research, ${ }^{43}$ the analysis of these phenomena in Niger has been less frequently conducted. ${ }^{44}$ The study of music itself is largely dominated by ethnomusicology studies - often conducted in nomadic societies ${ }^{45}$ - and hardly touches the field of Nigérien 'modern music'. ${ }^{46}$

Defined in contrast to the forms of 'traditional' music practised in specific communities, so-called 'modern music' in Niger emerged from the use of drums, keyboards, and electric guitars, combined with local percussion; it is first and foremost an urban phenomenon that developed in the wake of the Congolese orchestras of the 1950s. ${ }^{47}$ During the 1980s and 1990s, popular singers such as Moussa Poussi and Sani Aboussa embodied the evolution of Nigérien modern music, in which orchestras played a central role. Then, at the beginning of the 2000s, the emergence of hip-hop in Niger marked a major turning point, notably by renewing artistic and musical codes, but also by bringing forward a new generation of artists.

Modern music in Niger is not particularly internationalized and primarily targets the local public, which is divided, according to age groups, between orchestra lovers and hip-hop fans. By performing in bars and dance halls of major cities, as well as at weddings and naming ceremonies, orchestras have led the way for the professionalization of the musical sphere. However, apart from the few international stars, ${ }^{48}$ few Nigérien musicians manage to make a living solely from their art and many also have a 'real job' on the side.

43 Matthias Krings (2008), 'Conversion on screen: A glimpse at popular Islamic imaginations in northern Nigeria', Africa Today 54(4): 45-68.

44 Adeline Masquelier tackles it in her 20-year work on religious and social transformations in Niger, and particularly in Dogondoutchi, studying in particular the link between hip-hop music and religious identity among young people. See Adeline Masquelier (2010), 'God made me rap: Young men, Islam, and survival in an age of austerity'. In: Anne Haour \& Benedetta Rossi, eds, Being and Becoming Hausa: Interdisciplinary Perspectives, Brill, pp. 235-55; and Adeline Masquelier (2010), 'Securing futures: Youth, generation, and Muslim identities in Niger'. In: Asef Bayat \& Linda Herrera, Being Young and Muslim: New Cultural Policies in the Global South and North, Oxford Press, pp. 225-39.

45 François Borel (1988), 'Rythmes de passage chez les Touaregs de l'Azawagh (Niger)', Ethnomusicology Notebooks 1: 28-38; Veit Erlmann (1982), 'Trance and music in the Hausa Bòorii spirit possession cult in Niger', Ethnomusicology 26(1): 49-58.

46 Adeline Masquelier's work on the Nigérien hip-hop scene represents a major contribution to this littleinvestigated field. See Adeline Masquelier (2016), 'The mouthpiece of an entire generation. Hip-Hop, truth and Islam in Niger'. In: Soares, B. \& A. Masquelier, Muslim Youth and the 9/11 Generation, University of New Mexico Press, pp. 213-39.

47 François Bensignor (2005), 'La création musicale au miroir de l'histoire', Hommes et Migrations 1257: 125-33 (September-October).

48 Among the few Nigérien musicians who have succeeded in pursuing an international career, we can mention Moumouni 'Denke-Denke' and his group Mamar Kasey, or Tal National, the most famous 
Despite the difficulties of professionalization and the limited gains, musicians enjoy a large audience, particularly thanks to the broadcasting of their productions by Nigérien radio stations and television channels. In direct competition with preachers in the occupation of the soundscape, artists therefore use the same channels and often reach the same audience as their detractors.

Based on the 'perverted' nature of music, as well as the 'deviant' social practices that accompany it, the recurring condemnations of Nigerian Izala preachers echoed by their Nigérien peers - have been, like the whole Salafi discourse, gradually integrated and normalized. This has had a significant effect on the ways in which music is perceived, received, and produced in Niger. It is these changes that are studied here, illustrated by examples from the Niamey music scene, and which less reflect a global transformation of the artistic sphere or music market than a change in individual behaviours and intimate relationships with music.

With regard to rappers and orchestras, the sermons of preachers and more particularly those of the Izala movement are often extremely critical and sometimes even violent. Hip-hop artists, pejoratively nicknamed 'MCs', were first accused of reproducing a perverting Western cultural model that was contrary to Islamic values. Then, at the end of the 2000 s, when the hip-hop movement lost its dynamism while orchestras gained in popularity and audience, preachers reoriented their targets. They began to criticize the orchestras for the indecent lyrics of their songs, the vulgarity of the dances that accompanied the music and, more broadly, the way of life they encouraged: alcohol consumption, nightlife, and prostitution.

\section{The experience of the Tal National group: Promotion through censorship}

In this context of sharp criticism launched by some religious actors, the experience of Tal National is particularly interesting. From the end of the 2000s until today, Tal National has been the most popular orchestra in Niger; it sold out at each of its concerts, and when not on tour in the United States or Europe, it performs every weekend in a dedicated concert hall in the centre of Niamey. In 2009, Tal National's second album had great success, with songs playing on radio and television channels across the country. However, the songs, and especially the dance movements that accompanied them, provoked the indignation of religious actors. A group of Izala preachers operating on Dounia radio and television stations then mobilized, multiplying sermons, condemning Tal National's songs and videos, and describing them as depraved and perverse. While Tal National was preparing its third album, the same group of preachers tried to ban the release of the album and prevent the group from performing, claiming in particular that the

band in Niger, mentioned further in this chapter and which regularly performs in Europe and the United States. 
dancers were undressing on stage. They put together a file, with testimonies and photos to support their claim, which they brought to the presidency. An investigation was then opened, and the group leader, Almeida, was interviewed by the police several times, including by the 'brigade des mœurs' (vice squad). However, Almeida, a lawyer by training and a clerk at the Niamey High Court in his spare time, knew the accusations of indecent assault his orchestra was charged with, which was based in particular on the 'exchange of loincloths', allegedly practised on stage by the dancers. ${ }^{49}$ With the lack of evidence, the proceedings were dropped and the band's activities continued.$^{50}$ Faced with the failure of legal recourse, preachers intensified their sermons, calling on the faithful to boycott concerts, issuing a fatwa against its leader and encouraging people to fast to curse the artists.

When he recounts this episode, Almeida denounces 'the hypocrisy' of preachers, their 'purely defamatory approach' ${ }^{51}$, and in turn mobilizes the moral register. He refutes the accusations of the preachers and also suggests that they themselves 'were not good examples'. He claims to have evidence of their inappropriate conduct but says he chose not to disclose it, in order 'not to damage the image of Islam' ${ }^{52}$. Quoting from the Quran, he explains that God is always 'beside the one who holds the truth'; that it was therefore useless to accuse, in return, the 'marabouts'; and that it was better, faced with hypocrisy, to remain silent and 'take the path of God'. ${ }^{53}$ For Almeida and the other members of the group, who are 'all Muslims', assuming the popular and entertaining character of their art does not require abandoning Islamic moral values. On the contrary, not responding to attacks and avoiding escalating the debate even allows Tal National to display a higher level of ethics than the preachers.

Almeida uses a rhetoric in which the religious register occupies a deliberately and strategically reinforced role. If he puts forward his own morality and religiosity in the face of accusations from preachers, he also admits that the debates provoked by these attacks did not disadvantage his band. On the contrary, the reviews proved to be formidable advertising campaigns: the more Tal National was accused of perversion, the more popular it became, the more albums it sold, and the more concert halls it filled. This phenomenon, described by Almeida as 'the attraction of the forbidden fruit',${ }^{54}$ has therefore become a real promotional tool. However, it is difficult to say that Tal National's approach was to deliberately choose provocation for commercial purposes; it seems that the band has also

49 Dancers would have exchanged, and thus removed, their loincloths on stage, partially stripping their clothes in the process.

50 Interview with Almeida, leader of the Tal National group, in Niamey on 27 February 2015.

51 Interview with Almeida, leader of the Tal National group, in Niamey on 27 February 2015.

52 Idem

53 Idem.

54 Idem. 
developed the capacity to accommodate critics by using them to its advantage. This is an adaptation capacity forged by a long artistic experience of stigmatization religious but also social - that accompanies any musical career in Niger. Reaffirming its own Islam, Tal National managed to legitimize its opposition to preachers.

\section{2. (Dis)engaged rappers}

When the hip-hop movement emerged in Niger in the late 1990s, it was strongly influenced by American rap; over the next decade, it developed its own identity and became the main component of the Nigérien music scene, in the capital but also in the provincial cities, where dozens of hip-hop groups were formed. In the 2000s, rap represented the main part of the musical programming of radio stations, television channels, and theatres, in particular the Centre Culturel FrancoNigérien, then known as 'the temple of hip-hop'.

By providing engaged texts, Nigérien rappers took part in the protest tradition of the hip-hop movement that developed elsewhere on the continent - in Senegal, Burkina Faso, and Cameroon, for instance - where rap music offers youth a new way of expression. ${ }^{55}$ For about ten years, Niger's pioneer groups (e.g. Lakal Kaney, Wassika, Wongari, Kaidan Gaskia, Djoro G), quickly followed by new bands (e.g. Sah Fonda, Wass Wong, Kaidan Gaskia 2, Metaphor, MTS Matassa), conveyed a political message, criticized neo-colonialism, bad governance, and injustice, ${ }^{56}$ taking very seriously the mission of 'conscientization' that is characteristic of an 'authentic' rap. ${ }^{57}$

With regard to religion, on the other hand, and despite the attacks to which they were subjected, rappers remained quite silent. The texts themselves rarely refer to religion, and there are only a few symbolic markers of attachment to Islam (e.g. in some stage names). ${ }^{58}$ This does not prevent many artists from proclaiming their faith and easily assuming the reconciliation of their Muslim identity with their rapper status.

In the Nigérien audiovisual landscape, the hip-hop movement is therefore developing in parallel with the re-Islamization process launched a few years earlier by the reformists. On the radio, sermons and musical programmes dominated by hip-hop follow one another, and the hosts - who play an essential role in promoting Nigérien rap - share airtime with preachers, especially Izala, whose speeches

55 See the special issue: 'Polyphonies du Rap', Politique Africaine 141, 2016, $206 \mathrm{p}$.

56 In 2006, following the arrest of journalist Maman Abou and his sentence of 18 months in prison by the government, a group of rappers recorded the song 'Changement', denouncing violations of press freedom in Niger (https://www.youtube.com/watch?v=7AJYoZeOVoc).

57 Alice Aterianus-Owanga \& Sophie Moulard (2016), 'Cherchez le politique ... Polyphonies, agencéité et stratégies du rap en Afrique', Politique Africaine 141: 5-25.

58 One of the leaders of the Wass Wong group took, as stage name 'Almami (Imam) Koye'. 
remain very critical of music and of rap in particular. Star hosts ('Fan Flex' on Dounia, 'Do Masta' on Saraounia FM, 'K'stro' on Radio-Television Ténéré, and 'Big Posé' on Radio Alternative) regularly meet their detractors, but generally maintain cordial relations with them - partly owing to the respect imposed by the age of the 'marabouts' and the social status granted to them by their religious knowledge. While the coexistence of hip-hop music and reformist discourse in Niger's soundscape does not seem to be an apparent problem, it does expose the confrontation of two diverging registers and highlights the contradictions with which rappers must deal. As Adeline Masquelier has shown, most young artists manage to compartmentalize the different components of their identities and negotiate the terms of their own morality. ${ }^{59}$ For some, however, the irreconcilable nature of different moral and ethical registers reflects personal questions and profoundly disrupts their artistic approach; shaken in their Islamic identity, in search of meaning and coherence, some decide to abandon music.

'Jazz', a member of the MTS Matassa group, for example, chose to put an end to his musical career at the very moment when interesting opportunities arose:

I was sent by UNICEF to represent Niger at a Forum in Addis Ababa. We were coming to the end of sufferings. Working with UNICEF is a great opportunity. But even then, changes had already begun in me. [...] Back from touring, I started to feel disgust for what I was doing. My music no longer interested me; I no longer wanted the stage; my songs hurt me. [...] So I directed myself to the mosque, into prayer and readings. I had the love of taking refuge in the mosque and learning. [...] But then, it was the city that disgusted me; I didn't want to stay there anymore. I left Niamey for Nigeria; I stayed there for a year. I received religious training there, a good foundation that I didn't have before. I wanted to completely disappear from the world, from fame. I learned to understand my religion and its rules to practise it well. I understood, after returning home, that this music, hip-hop, is now prostituted. In concerts, young people meet up for alcohol, flirting, smoking weed, which doesn't go with the original ideology. At first, hip-hop was about awareness. Today, young people gather to 'délinquer' $[\ldots]$

Music is a problem; there are debates, controversies. Some sects practise music, but normally instruments should not be used. For a Muslim, it's hard to do hip-hop. Mixing hiphop and religion is like mixing fire and water. [...] Today, everything is prostituted. Orchestras are all about moving your buttocks, showing nakedness, whereas in religion, these are things that are banned. [...] Art as such has no problem with religion. Not all art is prohibited; the problem is music and rhythm. The Prophet fought the rhythm; it is the rhythm that is satanic. If today I were asked, as a Muslim, what art form would I choose, I would do anything except music. $^{60}$

The choice of the term 'prostituted' to designate hip-hop marks the breaking point in Jazz's musical career. Once the analogy is made between entertainment and debauchery, between music and deviant practices, the loss of moral values becomes a major risk for the artist. Religion then provides him with a protective

59 Adeline Masquelier, 'The mouthpiece of an entire generation' ... op. cit.

60 Interview with Jazz, former member of the MTS Matassa group, conducted in Niamey on 29 June 2015. 
frame of reference ${ }^{61}$ and allows him, strengthened by certainties of this 'true' acquired knowledge, to condemn artists as much as their public, for whom music would ultimately no longer be perceived as a form of art but simply as a support to 'délinquer'. ${ }^{62}$ The Izala standards are very clearly reflected in Jazz's selfformation process, characterized by the choice to go into exile in Nigeria, a country that, for many Nigériens, embodies the guarantee of authentic Islamic practices.

The antagonism between religious and artistic fields can also be less linear, with episodes of spiritual quest, isolation, and intermittent musical activities. This is for example the experience of Bilal Keit, leader of Wass Wong hip-hop group, which in the early 2000s was a resounding success in Niger. After several artistically successful years, Bilal distanced himself from the rest of the group, rarely participating in rehearsals and devoting more time to prayer and reading the Quran. After an interlude of several months, he finally decided to move to London. There, he attended a mosque apparently close to Salafi movements and aroused suspicions from the British authorities. ${ }^{63} \mathrm{He}$ then returned home and tried to re-launch a solo career. In 2014, for the release of his new song, he gave an interview in which he looked back at his artistic career and his years of interruption:

The main reason for this retirement is my relationship with God. We live in a predominantly Muslim society, and I did not have a deep understanding of the interpretation of the verses of the Quran. Spirituality, it has given me a lot, and it has given me more strength. It gave me a strong spirit, and faith. [...] And for that reason I was ready to sacrifice this artistic side to show my gratitude to God. But over time, I came to understand that it was a matter of interpretation. It all depends on the way we use this music. It can be used by the devil, just as it can be used to do good. ${ }^{64}$

His spiritual approach, like that of Jazz, responds to a quest for meaning that also finds answers in the reformist discourse. The argument on the rejection of music, however, did not find in him an echo strong enough to lead to a total abandonment of his artistic activities. His vision of music significantly changed, nevertheless, marked by a new puritanism, typical of the Izala discourse:

In Niger, we have a very decent culture. But I see that today, there are many things that are shown on television that can only negatively influence our youth. And I tell these young people to be very careful about what they see on television and not to forget where they come from. You shouldn't think that making music is about showing naked women, or perversion. How many artists have succeeded in their careers without falling into this? We must keep this sense

61 Abdoulaye Sounaye, Islam and Modernity. Contribution à l'analyse de la ré-islamisation au Niger, op. cit. p. 115.

62 Neologism derived from the French noun 'délinquance' (delinquency).

63 Based on informal discussions with other Wass Wong members, close friends of Bilal and with Bilal himself, in Niamey between 2009 and 2011.

64 'Interview with Bilal Keit, Nigérien Hip-Hop and Reggae artist', Le Sahel, 19 June 2014. 
of scruples that we have, and we must avoid perversion, because when there is perversion, there is immorality. We must preserve our social values through the education of children to ensure a bright future for them. ${ }^{65}$

As in Jazz's testimony, Bilal's reference to orchestra serves both to denounce their immorality and to enhance his own religiosity. The two rappers differ in their interpretation of the place of music in Islam but display a comparable ethical approach, both considering themselves more 'responsible' than their elders.

Of course, religious discourse alone cannot explain all the transformations that have occurred in the hip-hop movement in recent years; the vicissitudes of artistic careers are also linked to the rare professional opportunities and the extremely constraining economic context, as well as to the emergence of new musical trends. Indeed, from 2010, the stars of Ivorian Coupé Décalé and Nigerian pop music posed serious competition to Nigérien hip-hop, which then showed signs of slowdown. Partly explained by economic constraints, the departure abroad of several emblematic rappers from the Nigérien scene contributed to the renewal of the musical landscape. Some leading groups have disappeared and new groups have emerged, somehow managing to keep the movement alive by integrating the codes of pop music, often at the expense of the political message that characterized the movement in its early days.

\section{Islamic rap or religious performances?}

During this decade of change in the hip-hop sphere, new musical phenomena have emerged, revealing the persistence of moral contradictions and ethical questions among artists. Two examples illustrate this in particular, through the forms of musical creation chosen and the search for a compromise between artistic performance and religious injunctions.

The first example is that of Bachirou Chitou Issa, a host on Al-Ummha, a private Islamic radio station, who released an album of religious songs in 2011. Although his artistic approach is clearly part of an Islamic agenda, Bachirou Chitou Issa produced his album with the support of structures traditionally devoted to the production and promotion of hip-hop: first, the CFPM (Centre pour la Formation et la Promotion Musicale) in Niamey, where recordings and arrangements were made, and then the Centre Culturel Franco-Nigérien, where the opening concert was organized. Moov, one of the African branches of the Emirati telecommunication operator Etisalat, sponsored the event. For the first time, a Nigérien artist followed the same creative process as hip-hop groups, received

${ }^{65}$ Idem. 
support from public structures ${ }^{66}$ and a private company, and delivered a musical product entirely dedicated to religion.

On stage, Bachirou, accompanied by six back-up singers, performs all his pieces in Arabic and a capella, following the tradition of nasheed, ${ }^{67}$ a religious song without instruments, very popular among Muslims in countries like Saudi Arabia, Malaysia and Indonesia. Until then, religious television channels such as Bonferey broadcast anasheed videos produced in the Middle East or Southeast Asia, which helped to popularize this exogenous musical genre. With Bachirou Shitou Issa's album Niger witnessed the first local form of anasheed production, the only musical style permitted by the Izala canon. The fact that Bachirou was trained at the Sheikh Abubakar Mahmud Gumi College of Higher Islamic Studies in Zaria (northern Nigeria), and then at the Islamic University of Say, in Niger, probably explains why he developed this form of art rather than another. But the particularity of his approach lies in the fact that he has succeeded in integrating himself into a musical landscape strongly marked by hip-hop and that he has managed to negotiate a place for religious music with Nigérien cultural actors and audiences.

The second example is that of the slam poet Goulam, whose career began in 2013 with the song 'Mohammed Le Plus Grand'. Goulam claims slam - a form of poetry that comes directly from North American hip-hop culture - as his medium for artistic expression, while developing his texts based on a critique of Western culture and a return to Islamic values. His second track, released in 2014, ' $M a$ Sœur', is a plea for the wearing of the hijab, a track on which Goulam criticizes France in particular for its intolerance towards veiled women. Goulam then received the support of Bonferey television, which produced the video clip and broadcast it regularly on its channel, thus ensuring the success of the song. Phonically, this slam differs from the classics of the genre only by the total absence of musical instruments, the background melody being composed solely of voices. Visually, the music video of 'Ma Sœur' is comparable to any Nigérien rap video: shots taken in the streets of Niamey, special effects, and visual animations. It also includes excerpts from French TV shows and from an interview with Diam's, the French rapper who has converted to Islam. ${ }^{68}$ The message focuses on the risk of perversion of moral values resulting from the abandonment of good religious practices:

\footnotetext{
66 ' The CFPM and the CCFN report respectively to the Niger Ministry of Culture and the French Ministry of Foreign Affairs.

67 The nasheed (pl. anasheed) is a religious poem sung in Arabic a capella. Anasheed videos, produced in the Gulf countries but mainly in Malaysia and Indonesia, are broadcast by many Nigérien and Nigerian television channels, especially during Ramadan periods.

68 The clip 'Ma Sceur' can be viewed on the YouTube platform:

https://www.youtube.com/watch?v=OZGzKCvJ0rc
} 
People point at you because debauchery you refuse

You refuse to be made into an object that people use

Because you do not want to be abused

Or for your voice to sing trivialities that just amuse

[...]

But if there is something that you should know,

It's that you should never let go

Succeed, they will

If ever of your Islamic values you speak ill.

Let them say your hijab is a tarp or a mask

Remain calm and faithful to your task.

No to actresses and crazy female singers

Whom Satan holds by the collar:

A people that just holler. ${ }^{69}$

Photo 7 Screenshot of Goulam's music video "Ma soeur"

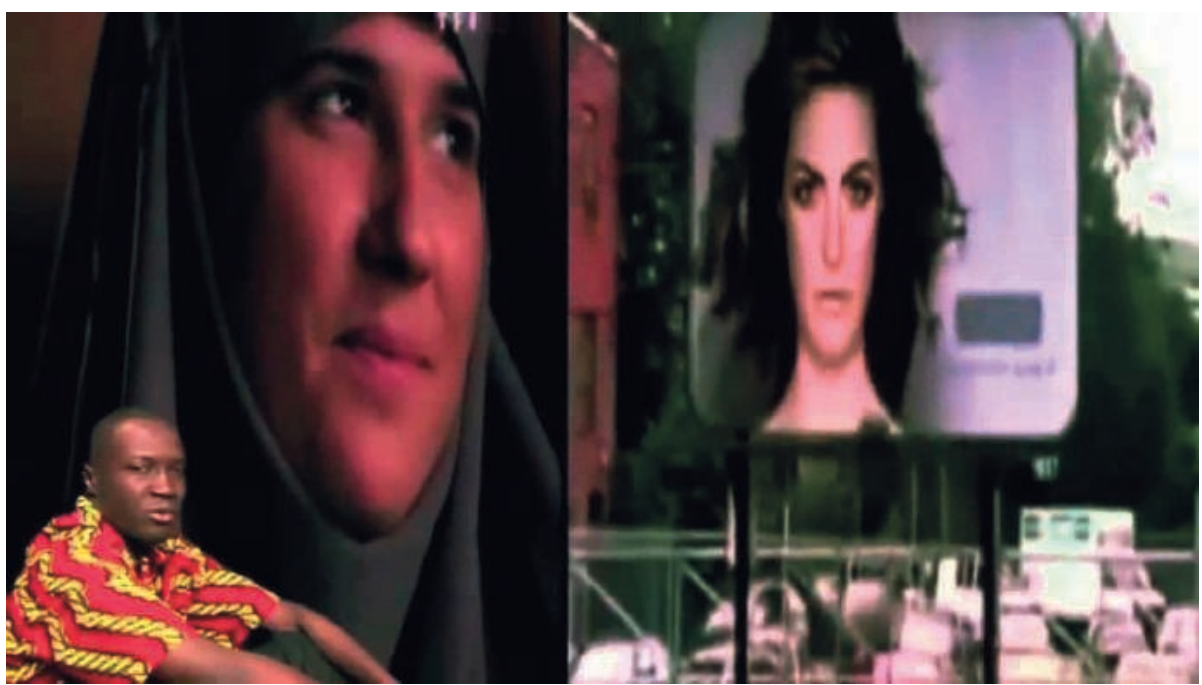

Like the preaching rappers studied by Abdoulaye Niang in Senegal, ${ }^{70}$ Goulam is at the crossroads of two important social dynamics: the strengthening of spirituality, on the one hand, and the use of hip-hop culture as a cultural and

69 'Tu es indexée par qu'à la débauche tu te refuses, tu refuses que l'on fasse de toi un objet dont on use, Parce que tu ne veux pas que toi on abuse, Ou que ta voix chante des futilités que les amuse (...) Mais s'il y a une chose qu'il faut que tu saches, C'est qu'il ne faut jamais que tu lâche. Ils réussiront si jamais tu craches, Sur tes valeurs islamiques comme une lâche, Qu'ils traitent ton voile de masque ou de bâche, Reste calme et fidèle à la tâche. Non aux actrices et chanteuses folaches, Que Satan dirige par sa cravache: Un peuple qui beugle comme une vache.'

70 Abdoulaye Niang (2014), 'Le rap prédicateur islamique au Sénégal: une musique "missionnaire", Volume! 10: 69-86. 
identity referent, on the other. He is also an actor - conscious or not - of the reinvention of popular culture in Niger who, by drawing on the hip-hop repertoire, renews the codes of religious performance.

\section{Conclusion}

Over the past twenty years, preachers and musicians have shared the soundscape in Niger, using the same distribution channels, often addressing the same audiences and succeeding, alternately or simultaneously, in seducing them. Regularly targeted by harsh criticism, and even condemnation, by preachers, the artists have maintained ambiguous relationships with them - sometimes cordial, sometimes confrontational, but always competing for the mobilization of youth. Thus put in opposition, these actors have developed divergent strategies and used different moral registers, but have sometimes also mobilized the same notions, such as justice or truth. ${ }^{71}$

The Izala reformist discourse and the renewal of norms that accompanied the re-Islamization process in Niger therefore had undeniable but multifaceted effects on the music scene. More or less sensitive to criticism, more or less affected in their work, artists have reacted according to their personality and individual stories, but reactions also have varied from one generation of musicians to another.

Orchestras, which have been present on the Nigérien music scene since the 1960s, have negotiated their place in the country's cultural landscape through different periods, facing all kinds of social, political, and religious constraints. Their long experience of the art scene and music-related issues in the contemporary context of Niger has undoubtedly helped to mitigate the impact of attacks against them. The rappers, on the other hand, arrived on the Nigérien music scene at a time when the re-appropriation of ethical and moral issues by religious reformists was already an advanced process and when the Izala rationale had already succeeded in imposing itself.

However, it is interesting to note that, when explaining their career choices, orchestras' musicians and rappers always mobilize the religious register, both to justify the morality of their approach and to reaffirm their own religiosity. Opposing, transforming, or re-appropriating Islamic norms, even if it means finding - or even inventing - a new mode of artistic expression, does not require artists to sacrifice their religious identity; on the contrary, in the face of adversity and contradiction, this identity tends to be reinforced. The musical innovations introduced by Nigérien artists in recent years reveal their ability to reconcile

71 Adeline Masquelier, 'The mouthpiece of an entire generation' ... op. cit. 
artistic creation and a reformist agenda, but also to define their own Islamic identity in a social space in crisis, economically and religiously competitive.

\section{References}

Adeboye, OlufunKe (2012), 'A church in a cinema hall. Pentacostal appropriation of public space in Nigeria', Journal of Religion in Africa 42(2): 145-71.

Aterianus-Owanga, Alice \& Sophie Moulard (2016), 'Cherchez le politique... Polyphonies, agencéité et stratégies du rap en Afrique', Politique Africaine 141: 5-25.

BENSIGNOR, FRANÇOIS (2005), 'La création musicale au miroir de l'histoire', in Hommes et Migrations 1257: 125-33.

BOREL, FrANÇOIS (1988), 'Rythmes de passage chez les Touaregs de l'Azawagh (Niger)', Cahiers d'ethnomusicologie 1: 28-38.

Brigaglia, AndreA (2007), 'The Kaduna Radio Tafsir (1978-1992) and the construction of public images of Muslim scholars in the Nigerian', Journal for Islamic Studies 27: 173-210.

ERLMANN, VeIT (1982), 'Trance and music in the Hausa Bòorii spirit possession cult in Niger', Ethnomusicology 26(1): 49-58.

GRÉGOIRE, EMMANUEL (1993), 'Islam and identity of merchants in Maradi (Niger)'. In: Louis Brenner,ed., Muslim Identity and Social Change in Sub-Saharan Africa, pp. 10615. London: Hurst \& Company.

Kane, Ousmane (1998), 'Le réformisme musulman au Nigeria du Nord'. In: Ousmane Kane, ed., Islam et Islamisme au Sud du Sahara, pp. 117-35. Paris: Karthala.

Krings, MATthias (2008), 'Conversion on screen: A glimpse at popular Islamic imaginations in northern Nigeria', Africa Today 54(4): 45-68.

LARKIN, BRIAN (2008), Signal and Noise: Media, Infrastructure, and Urban Culture in Nigeria. Durham: Duke University Press.

LoimeIer, Roman (1997), Islamic Reform and Political Change in Northern Nigeria. Northwestern University Press.

MAsquelier, Adeline (2010), 'God made me a rapper: Young men, Islam, and survival in an age of austerity’. In: Anne Haour \& Benedetta Rossi, eds, Being and Becoming Hausa: Interdisciplinary Perspectives, pp. 235-55. Leiden: Brill.

MASQUelier, Adeline (2010), 'Securing futures: Youth, generation and Muslim identities in Niger'. In: Asef Bayat \& Linda Herrera, Being Youth and Muslim. New Politics in the Global South and North, pp. 225-40. Oxford: Oxford University Press.

MASQUELIER, AdELINE (2016), 'The mouthpiece of an entire generation. Hip-hop, truth and Islam in Niger'. In: Soares \& Masquelier, Muslim Youth and the 9/11 Generation, pp. 213-39. Albuquerque: University of New Mexico Press.

MCCAIN, CARMEN (2013), 'Nollywood, Kannywood and decade of Hausa film censorship in Nigeria'. In: Daniel Biltereyst \& Roel Winkel Vande, eds, Silencing Cinema: Film Censorship Around the World, pp. 223-40. London: Palgrave MacMillan. 
MeUnier, Oliver (2002), 'Développement du wahhabisme au Niger: analyse sociohistorique de la diffusion du mouvement Izala dans la ville de Maradi', Revue africaine de recherche en éducation, 'l'éducation dans la société africaine', n'1, pp. 121-52.

Mouley, Hassane, Marthe Diarra \& Oumarou MaKama (2005), Etude sur l'Islam au Niger. Niamey: Danida.

NiAng, AbDoulaye (2014), 'Le rap prédicateur islamique au Sénégal: une musique "missionnaire", Volume! 10: 69-86.

Prud'homme, Pierre (2014), 'Les griots d'Allah ou l'émergence d'une musique religieuse populaire', Le Mali Contemporain, Marseille: IRD Editions, pp. 317-32.

SounAye, AbDoulaye (2009), 'Izala au Niger: une alternative de communauté religieuse'. In: L. Fourchard, O. Goerg \& M. Gomez-Perez, eds, Les lieux de sociabilité urbaine dans la longue durée en Afrique, pp. 481-500. Paris: L'Harmattan.

Sounaye, ABdoulaye (2011), 'La 'discothèque' islamique: CD et DVD au coeur de la réislamisation nigérienne', Ethnographiques.org No. 22, 'Les Outils d'un islam en mutation. Réislamisation et moralisation au sud du Sahara'.

Sounaye, Abdoulaye (2016), Islam et modernité. Contribution à l'analyse de la réislamisation au Niger. Paris: L'Harmattan.

Thurston, Alexander (2014), 'Muslim politics and Sharia in Kano State, northern Nigeria', African Affairs 114(454): 28-51.

Thurston, Alexander (2016), Salafism in Nigeria. Islam, Preaching and Politics, Cambridge University Press.

Toure, KADIDIA (2008), 'Telenovelas et dynamiques identitaires à Bouaké et Bamako'. In: Jean-François Werner, ed., Médias visuels et femmes en Afrique de l'Ouest, pp. 195-242. Paris: L'Harmattan. 


\title{
Pastoralism and Islamic practice in Fulbe communities of northern Nigeria and Niger
}

\author{
Adam Higazi
}

\section{Introduction}

There is presently widespread attention being given to the pastoral Fulbe in West Africa, mainly from a security standpoint, and to their Muslim identity that is also associated with the history of Islamic reform in the region. This study touches on some of these issues but it also aims for ethnographic depth, based on field research within specific pastoralist communities. ${ }^{1}$ In both Nigeria and Niger, Fulbe pastoralists are facing acute livelihood pressures and, in some areas, insecurity and conflict. The level of violence is particularly high in Nigeria, where over the past decade (since 2010) violent conflicts, often expressed in ethno-religious terms, have increased between pastoralists and farmers. ${ }^{2}$ In the Nigerian media and popular discourse, 'herdsmen' are widely stereotyped and maligned. Issues related to the access of communities to land and water in rural areas of Nigeria, Niger, and other parts of West Africa are necessarily political, but they have become more fraught and divisive as ecological and demographic pressures have increased.

\footnotetext{
Pastoralism here refers to the raising of livestock on an extensive basis, which in our case studies involves transhumance between dry and rainy season pastures and the movement of herds for daily grazing. The pastoralists studied here raise mainly cattle and sheep; some also have goats and in more arid areas there are also camels. Pastoral communities are made up of domestic units with gendered divisions of labour, and while men and women tend to be experts in animal husbandry and herding, pastoral production also includes a wider range of activities linked to herding, such as the selling of milk and dairy, the trading of livestock in markets, and in many cases subsistence farming. Some families are nomadic, some are settled, with gradations in between that involve different transhumance practices.

2 See for example Roger Blench (2018) and the MISEREOR website for field reports on farmer-herder issues from different Nigerian states - https://www.misereor.org/publications/food-security-andagriculture/\#c15694. The violent conflicts in rural areas of the Jos Plateau from 17 January 2010 and the spread of post-election violence in 2011 to southern Kaduna were key moments in the escalation of rural conflicts and insecurity in central Nigeria. See Higazi (2018) and Human Rights Watch (2013).
} 
Questions of access to and tenure over land and of the mobility of people and livestock are mixed up with national and local identity politics.

Pastoral and agricultural livelihoods are evidently under considerable strain in Nigeria and Niger, mainly due to uncontrolled population growth in those countries, the expansion of cultivation into what were previously grazing areas, and ecological degradation. Conflicts between pastoralists and farmers, when they arise, often occur along ethnic and religious lines, and can either lead to or be triggered by wider outbreaks of communal violence. These are generally, but not exclusively, conflicts with two or more sides involved, but both in Nigeria and Niger the conflicts have different forms and origins, with variation between locations and in terms of the type of armed groups involved. There are also pastoralist and farming communities in different regions of Nigeria and Niger who continue to live peacefully together.

The Fulani, or Fulbe (sg. Pullo) - their self-ascribed name in the Fulfulde language - have a distribution throughout West Africa, from Mauritania to Nigeria and Niger, and across parts of central Africa into Sudan. 'Fulani', as they are widely known in Nigeria and Niger, is the Hausa name for the Fulbe that has been adopted into English (whereas in French, Peul(s) is used, which comes from Wolof). With their wide geographical spread, the pastoral Fulbe are heterogeneous, with marked dialectical and cultural variations, but taken as a whole - and many do still have an imagined sense of cultural unity - they are the largest pastoralist population in Africa. They mainly raise cattle, but sheep and other animals are also important (and the Uda'en, a Fulbe sub-group, specialize in sheep). Most pastoral families now also farm crops on a subsistence basis - grains such as maize, sorghum, and millet, and vegetables like sweet potato and cowpea - even while raising livestock is their main activity and is central to their culture. They are the subject of an extensive ethnographic literature, although this is uneven in its geographical coverage and much of it is now dated. ${ }^{3}$ There are also many Fulbe who have settled or become urbanized, working in other sectors apart from pastoralism, such as in trade or as educated professionals. Even in more 'traditional' pastoral settings, the Fulbe are internally variegated, with strong identities based on lineage and clan ties (lenyi, sg. lenyol). The pastoral Fulbe are predominantly Muslim, but there is also a small and significant Fulbe Christian minority. Among the Muslim majority their internal diversity extends to religious knowledge and practice, part of the focus of this chapter.

Field-based research on pastoralists in Nigeria, which has the largest Fulani population, is limited. With a few exceptions, even much of the wider regional literature is now dated. But there are some seminal studies which provide important ethnographic insights and baseline data. These include, but are not limited to, pioneering monographs on the Wodaabe: Stenning (1959), Dupire (1962), and Bonfiglioli (1988). 
Map 6 Geographical distribution of Higazi's fieldwork

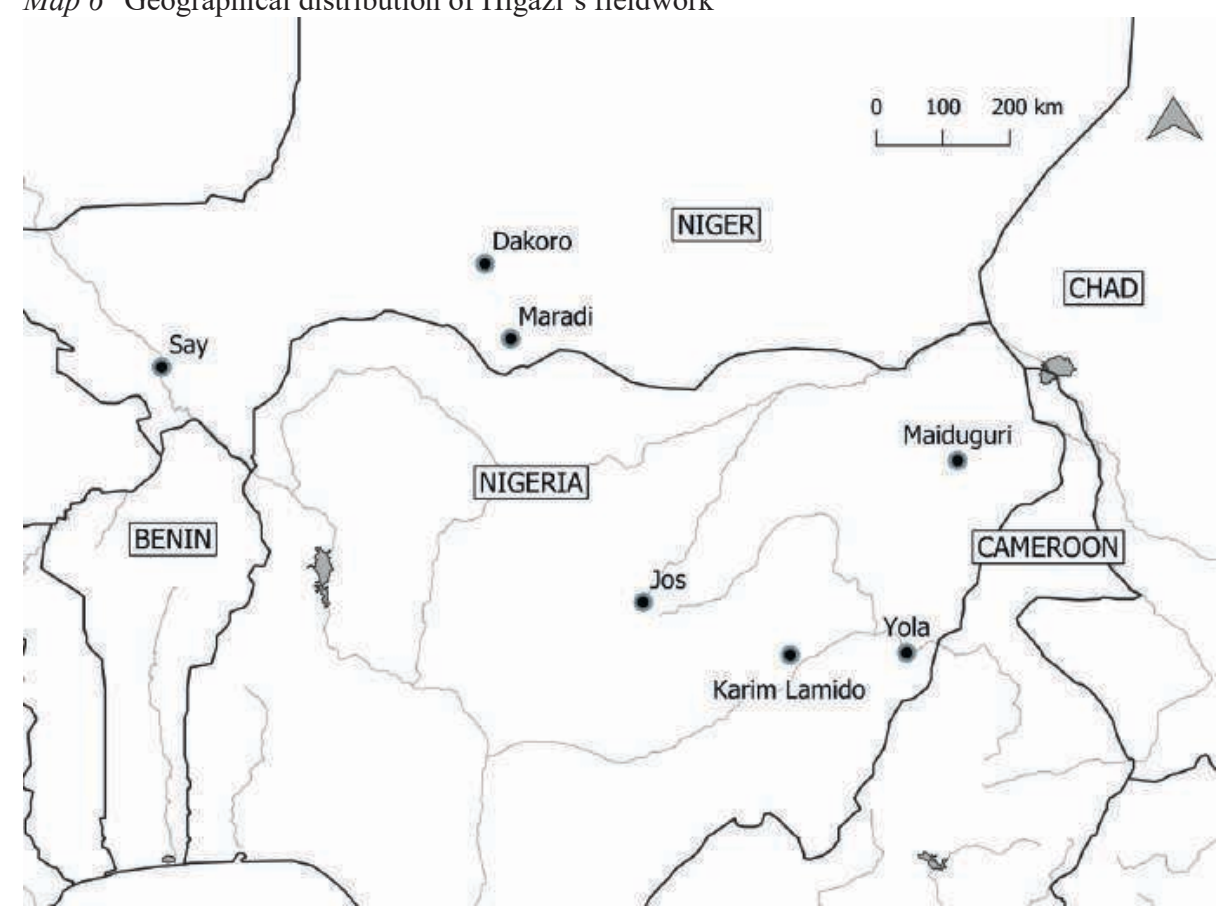

More evidence-based analysis is needed of the different forms of insecurity affecting pastoral and agricultural communities on both sides of the Nigeria-Niger border. The diversity of pastoralists and the current sociology of pastoral production need to be better understood, taking cognizance of processes of social, economic, and ecological change that they are affected by and responding to. ${ }^{4}$ This study was undertaken in that spirit of inquiry, with the aim of contributing to our understanding of what is happening within selected Fulbe groups in northern Nigeria and Niger. The main focus is on religious dynamics and practices, but during fieldwork both in Niger and Nigeria it was clear that social changes in the religious field could not be separated from wider pressures in the political economy of pastoralism and rural life. This chapter also touches on those wider issues and considers Islamic practice among the Fulbe in the context of changing pastoral livelihoods and of ecological and physical insecurity in the Savanna and Sahel. Conflict and the representation of pastoralists is considered below but the chapter does not aim to give a detailed regional overview. Its focus, ethnographically, is

4 A very good study investigating such issues in north-west Nigeria is by Saleh B. Momale (2016), but the levels of violence in the region have dramatically increased since that study was carried out. 
on specific pastoral groups and their social and environmental conditions in selected places in Nigeria and Niger.

In Nigeria and other parts of the region, the pastoral Fulbe have become increasingly typecast on an ethnic basis in popular and social media as tending towards 'militancy' and 'terrorism'. The problem is that it is a stereotype, and it is misleading and reductionist if we wish to understand Fulani societies in their complexity and full range, but it is one that has grown with increasing numbers of pastoral conflicts. The Global Terrorism Index feeds into this at an international level and singles out armed groups involving Fulani on an ethnic basis, labelling them 'Fulani militants' and 'Fulani extremists'. In 2015 the index claimed that 'Fulani militants' were the fourth-most deadly 'terrorist group' in the world behind Boko Haram, ISIS, and the Taliban, but ahead of Al Shabaab. ${ }^{5}$ Widespread cases of violent conflict between Fulbe pastoralists and farmers from different ethnic backgrounds were categorized as 'terrorism'. The 2017 report refers to 'Fulani extremists' and claims they are a 'subset' of Fulani herders, but again this is partial because it lists only alleged Fulani attacks, not violence against Fulani communities. Without any serious conflict analysis in the report, the Fulani are only presented as aggressors. ${ }^{6}$ The use of a single derogatory ethnic label for violence perpetrated by different types of armed groups stereotypes the wider Fulani population but it also means that these wide-ranging conflicts across the region are not disaggregated.

The 2019 report continues in this way, but states 'Events... attributed to 'Fulani Extremists' reflect the use of terrorism as a tactic in the conflict between pastoralists and farmers, rather than the existence of an organized terrorist group.' In fact, 'the use of terrorism as a tactic', defined in this way, could apply to most armed groups involved in inter-communal violence in Nigeria, to the different sides involved in conflicts between farmers and pastoralists, to the attacks carried out by militias on different sides of those conflicts, and to the violent actions and attacks by criminal gangs or 'bandits'. The index attempts to record and characterize acts of violence attributed to 'Fulani militants' in West Africa, which undoubtedly do occur, but not the violence of other protagonists in these conflicts or acts of comparable violence against pastoralist communities - of which there have been many. To add a religious connotation, it also made the odd assertion, without citing any evidence, that the majority of farmers in Nigeria are Christian, and suggested that 60,000 people had been killed in clashes between farmers and

5 Institute for Economics \& Peace. Global Terrorism Index 2015: Measuring and Understanding the Impact of Terrorism. In general, the data and interpretation is weak: http://economicsandpeace.org.

6 Institute for Economics \& Peace. Global Terrorism Index 2017: Measuring and Understanding the Impact of Terrorism. Online.

7 Institute for Economics \& Peace. Global Terrorism Index 2019: Measuring the Impact of Terrorism, Sydney, November 2019, P. 92. 
herders in Nigeria since 2001, on the basis of a completely unreferenced and unverified claim in a newspaper article. ${ }^{8}$

There are different types of conflict that Fulbe communities are affected by and involved in. There is communication in Fulfulde between Fulbe across the region, but there are also substantial differences between cases and in the social situations of the Fulbe. There are, for example, violent eruptions, especially in the Nigerian case but sometimes in Niger too, that have an ethno-religious or inter-ethnic expression, but the circumstances are locally defined and contexts vary. These may converge with and be driven by livelihood pressures and competition between pastoralists and farmers over land - often exacerbated by the land-grabbing of political and business elites. In other cases, attacks are perpetuated by criminal gangs or 'bandits' (Momale, 2016; Rufa'i, 2017), operating through rural-urban networks and sometimes with political protection. There is also a religious component to some of the conflicts, with different articulations, including jihadism as a mobilizing factor for some of the Fulani in confict zones of Mali, Burkina Faso and western Niger. If we look at the situation at a regional level, or even within Nigeria or Niger, there are different types of armed actors and multiple agrarian and pastoral groups involved across the spectrum of what are labelled as 'herder-farmer conflicts'.

The apparent increase in conflicts involving Fulbe groups - and the connection of these conflicts in some areas of the Sahel to what has been labelled 'the new wave of jihadist insurgency' in West Africa (Ibrahim 2017: 5) - has raised questions about religious trends within the pastoral Fulbe. In the current political environment, the proliferation of violent conflicts involving and affecting pastoralists in West Africa is being linked to a so-called 'Fulani question' (or 'la question peule'). This hinges on concerns about the recruitment of Fulbe youths in parts of the region into 'violent extremist groups', which is certainly happening in some areas but it does not reflect current patterns of Islamic expression within pastoral Fulbe groups more generally. The social base of the Katibat Macina of Ansar Dine in central Mali is Fulbe, but the context of recruitment also needs to be understood, as it has occurred in a situation of war and civil insecurity in Mali - following earlier Fulbe recruitment into Mujao, to counter the Tuareg-dominated MNLA (National Movement for the Liberation of Azawad), with the outbreak of war in Mali in 2012. The Islamic State in the Greater Sahara (ISGS), founded in 2015-2016, also recruits among the Fulbe (though not exclusively), notably in the Liptako Gourma area where the borders of Niger, Mali, and Burkina Faso intersect. ISGS attacks have extended into Burkina Faso and western Niger. In Niger, it is particularly the areas of Tillaberi and Tahoua regions bordering Mali (Gao region) that are affected. UNHCR reported that 52,000 Nigérien civilians were displaced

8 Ibid. 
by the violence in 2018 , in addition to the 53,000 Malians already registered as refugees in Tahoua and Tillaberi regions. ${ }^{9}$ The impacts of war, banditry, interethnic tensions, the mobile lifestyle of pastoralists, their grievances about diminishing access to pasture and water, their regional networks, and $19^{\text {th }}$ century precedents of Fulbe-led jihads in West Africa (Last 1987) are all cited as factors in the recruitment of some sections of the Fulbe in the Sahel into jihadi groups. ${ }^{10}$

The insurgencies in the central Sahel and the Lake Chad Basin are of course not the only sites of conflict in the region, but they are also not reflective of wider Islamic practice and cross-border connections (which can also be positive - for example, linked to trade or peaceful transhumance). There are, however, genuine grievances and livelihood pressures among the pastoral Fulbe in Nigeria and Niger. Across wide areas of Nigeria, especially, there is endemic insecurity and violence, which pastoralists are affected by and in some cases participants in. The recruitment by organized jihad movements of pastoral Fulbe in Nigeria (as of mid2020) in current conflicts has been limited, but that does not mean it could not become a more significant trend. ${ }^{11}$ The main risk is of increased cross-border flows between violent movements operating in Mali, Burkina Faso, and western Niger and armed groups in north-west Nigeria, where civil insecurity caused by rural banditry and state failure is already costing many lives. In north-west Nigeria, armed criminal groups already carry out large-scale attacks in rural areas inflicting mass casualties without the motivation of international jihad, so the latter is clearly not a prerequisite for violence. In the central zone of Nigeria, farmer-pastoralist conflicts often occur along religious lines, and fighters on both sides - Christians and Muslims - mobilize around ethnic and religious identities and ideologies. Militancy and arms proliferation have increased over several decades. There are also internal feuds within the pastoral Fulbe in Nigeria and violent conflicts between farmers, most destructively between the Tiv and Jukun (this is inter-

9 The United Nations High Commissioner for Refugees (UNHCR), 'Violence displaces more than 50,000 in western Niger this year'. 13 December 2018.

https://www.unhcr.org/uk/news/press/2018/12/5c122b944/violence-displaces-50000-western-nigeryear.html. Accessed on 11 July 2019.

10 For a comparative regional study on the various forms of insecurity facing and involving pastoralists in the region, see A. Higazi \& S. Ali (2018), Pastoralism and Security in West Africa and the Sahel: Towards Peaceful Coexistence. Dakar: United Nations Office for West Africa and the Sahel. Online.

11 There are some individual Fulbe who have taken up arms with the Islamic State in West Africa Province (ISWAP) in northern Borno, but the numbers are unclear. It appears to be a small number. In Abadam five families (households) had reportedly joined, splitting from their ethnic kin. The general trend in Borno and Yobe within the Fulbe to date has been either neutrality or opposition towards the jihadist groups, but with attempts to negotiate access to pasture where possible and in some cases trade. JASDJ and ISWAP being Kanuri-led is likely to be a factor in the low level of Fulbe recruitment. There has been much armed opposition from Fulbe herders against the Shekau faction around the Sambisa forest but more of an accommodation in the ISWAP controlled areas. (Author fieldwork within pastoral Fulbe in Maiduguri and Yobe State, August-November 2019). 
ethnic, both groups are mainly Christian) in Taraba and Benue States. ${ }^{12}$ Religion as ideology and as an aspect of group social identity is a feature in many of these conflicts, but clearly not in all of them - other factors are vital too.

With the understandable focus on violence and insurgency and problems of access to the field for researchers due to insecurity, there is limited empirical data on what is happening more broadly in religious terms within Fulbe populations across the region. Does religion feature in their own expressions of grievance - for example, in relation to the state or other communities - or in demands for change? Even as some pastoralists in the Sahel have entered militant groups, what are the broader social and religious trends in pastoral communities? This study aims to address these questions in relation to specific cases.

What follows is based primarily on field research carried out by the author in northern Nigeria and Niger Republic in 2015-2016 and updated with references to more recent fieldwork in 2017-19, among Fulbe pastoralists and their agriculturalist neighbours, in selected research sites. I do not present this as a general study of the Fulbe in Niger and Nigeria, but rather of the selected cases, which may nonetheless reflect and shed light on issues that are of wider relevance.

\section{Social and historical context}

Fulbe groups in Nigeria and Niger can be usefully compared because they are present in both countries and there is cross-border mobility and transhumance. Pastoralists face challenging ecological, demographic, and political conditions in both cases. However, the scale and extent of violent conflict in Nigeria is greater than in Niger. Even allowing for Nigeria's much larger population, the scale of violence in pastoralist conflicts there is unusually high - often with hundreds of fatalities in a single violent episode. A prominent part of the public, political, and media discourse on these conflicts in Nigeria is that this violence is being imported from neighbouring countries, including from Niger. The allegation is that the attacks are being committed by 'foreign herdsmen' who have either migrated to Nigeria for transhumance or been invited by the 'local Fulbe' to fight for them. At times explicit, and at other times implicit, within these dominant representations of what is happening is the assumption of both a 'Fulani' and 'Islamic' threat to local communities. The regional dimension to Nigeria's farmer-herder conflicts appears to be grossly exaggerated, possibly driven by the wish of government officials to deny responsibility for the violence by blaming it on external factors that they have less control over. It is also part of a xenophobic discourse that presents the Fulbe in Nigeria as foreign, when the Fulbe presence in the far north

12 The Daily Trust, 'Taraba - why Tiv-Jukun crisis refuses to end', 1 September 2019: https://allafrica.com/stories/201909020456.html 
of what is now Nigeria probably dates back to the $14^{\text {th }}$ century (Nelson 1997: 19, citing the medieval Arab historian Makrizi's recording of a Fulbe presence in Borno).

\section{Islam and culture among the pastoral Fulbe}

The level of religious observance varies among the pastoral Fulbe, as does their affiliation to specific Islamic groups. The cattle-rearing Fulbe, who live as nomadic or transhumant pastoralists are variously called, in Fulfulde, Fulbe rimndoobe, Fulbe jogiibe na'i, Fulbe bayrugol, or Fulbe gaccungol. They are traditionally perceived as being 'lax' Muslims or only 'nominally' Muslim (St Croix 1945). The relaxed attitudes of the nomads in religious matters may be contrasted with the religiosity of settled Fulbe communities (variously called Fulbe joodiibe, Fulbe taaku'en or huya'en). There is some truth to this, but it is an overgeneralization and fails to consider pastoralists' self-perceptions and their own beliefs. Religious observance may be minimal in some cases; historically due to the demands of nomadic life and cultural practices that are not Islamic in origin and are associated with their raising of livestock. But more widely there has been an increase at least in outward signs of religiosity among the pastoralists.

Photo 8 Mosque and elderly sheikh in Gelohoy, a mainly Fulbe (Tijaniyya) village, Say Region, south-west Niger (Photo: Adam Higazi)

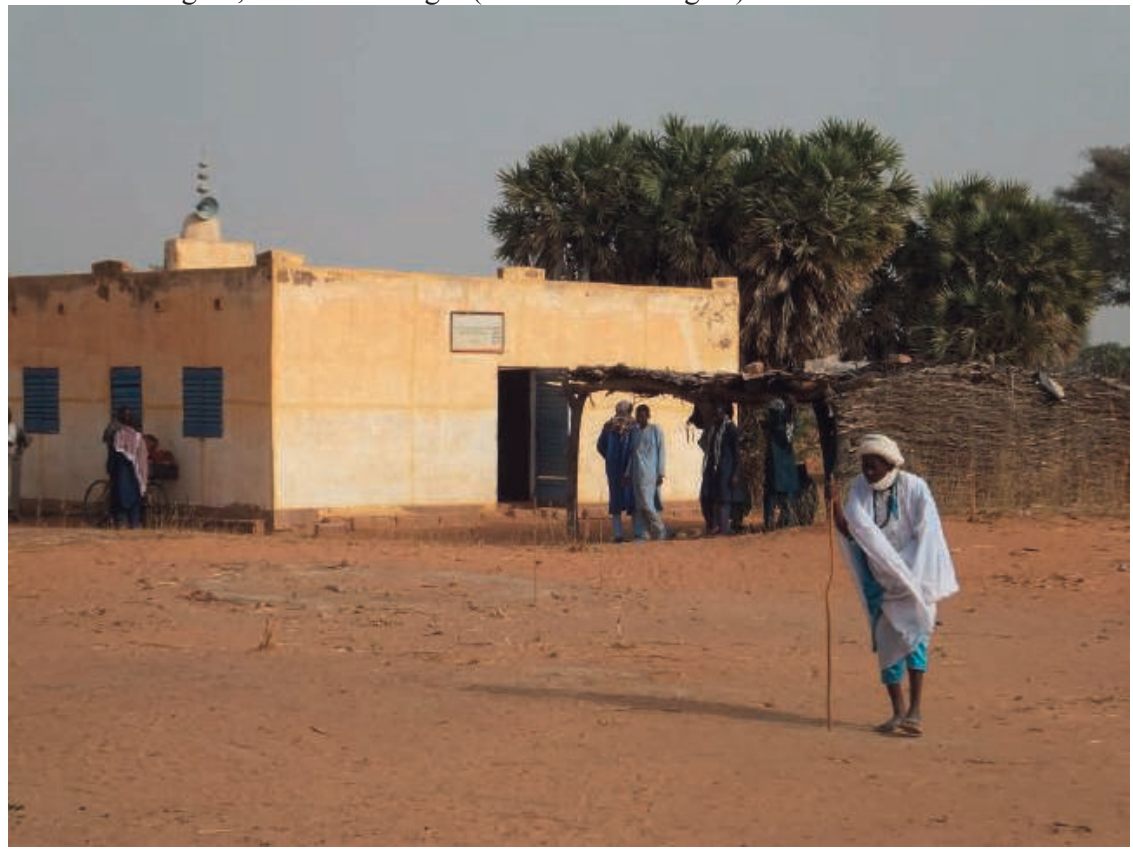


Adherence to Islam and the place of Islamic rituals in pastoral ceremonies (kumte, sg. humto) of Wodaabe patrilineal clans in Borno were already recorded by Derrick Stenning in the 1950s. He showed how Islamic observance depended on the ceremonial context and the practical demands of pastoral life (with only selective observance of the five daily prayers and of fasting during Ramadan). There was usually Islamic content in individual rites of passage, such as naming ceremonies (kumte innde) and in most types of marriage ceremony (Stenning identified five types of Wodaabe marriage) (Stenning, 1966: 395-6). Islamic prayers were given in most public ceremonies performed by the Wodaa6e, but the cultural content of the dances (such as daddo) and other public activities, was not religious. The ownership of cattle and the establishment of family herds were also worked out culturally, in ceremonies informed by Wodaabe pastoral practice rather than religion: 'where changes in the rights over cattle are concerned, no Islamic ceremony is countenanced, even in respect of the individual whose change of status is implicit in the event' (Stenning 1966: 398). The degree of Islamic observance thus varied depending on the material and ceremonial context.

This prompts certain questions. How have changes in the pastoral economy and pastoralist societies affected the interaction and balance between religious and cultural values? Are there differences in Islamic practice between sedentary and nomadic populations? How do pastoralists express their religiosity? Is there a 'scriptural' Islam that emphasizes 'orthodoxy', represented by a literate, urbanbased ulama, and a 'local' Islam prevalent in rural areas and pastoralist communities that is more oral and perhaps more syncretic and tolerant of folk cultures and traditions?

Historically among the Ful6e, distinctions were made between the clerical class of Islamic scholars (moodib6e, sometimes connoted as a clan, torodbe), on the one hand, and the nomadic pastoralists on the other, with their supposedly more superficial understanding of the religion and their greater adherence to 'Fulbe culture' (notably the precepts of pulaaku, an idealized set of cultural rules). These social divisions were not clear-cut, as there were interactions and sometimes kinship links between religious scholars, political office holders, and pastoralists, and scope for individuals from pastoralist backgrounds to shift vocation, especially in cases of individuals with access to religious education (this also happened in the $19^{\text {th }}$ century, under different circumstances, in the Sokoto Caliphate: see Usman 1981; Burnham \& Last 1994: 327). In anthropology, these distinctions in religious and cultural practice were juxtaposed as the 'great' and 'little' traditions within a culture (Redfield 1956). The idea of an interconnected but distinct 'great tradition' and 'little traditions' has been applied to religions, to account for the diverse local appropriations and practices within specific religious traditions: 
In any civilization, there is a great tradition of the reflective few, and a little tradition of the largely unreflective many. The societal dimensions of these two traditions are the great community and little community. Thus, the great tradition is the culture of the great community of priests, theologians, and literary men who may not even have seen the village. Those two traditions are not mutually exclusive, but interdependent ... . (Obeyesekere 1963: 139)

This model was applied to the study of Islamic societies by Ernest Gellner (1981), writing on Morocco but generalizing the model rather widely. The dichotomy may be less generalizable in a 'modern' context where literacy and religious education have increased, including in rural areas, but it may still have applicability in some contexts. In northern Nigeria and Niger, it cannot be argued that the urban-based ulama have not seen a village, nor that rural folk do not have urban connections. Furthermore, there has been a fragmentation of religious authority, among both Muslims and Christians in Nigeria and Niger. There has been a proliferation of different Islamic (and Christian) organizations, preachers, and mosques, ${ }^{13}$ often with competition between factions or sects for control of mosques (see Gwadabe, this volume). The model, however, does raise questions about variations in Islamic practice between different social and geographic contexts. If there is a 'great tradition', it is to the extent that there is a literate, Arabic-speaking ulama with an orientation towards scriptural-based knowledge of the Islamic religion, but the ulama represents different traditions of thought and practice within Sunni Islam.

The 'little traditions' of popular or folk Islam in Nigeria and Niger representing 'local' forms of the religion - have been associated with those outside the reformist currents of mainly urban-based Islamic groups. They are often the targets of those reformists who oppose cultural practices that they allege are unIslamic or 'syncretistic' innovations (bid'ah), but some pastoral traditions are also suppressed by Tijanis (see below). The selective application of what may be called Fulbe cultural practices and Islamic practices that Stenning (1966) documented can still be seen today, but the configuration between the two has changed. The nature of Islamic practice also depends on the Fulbe community in question: there is evidently significant variation even within northern Nigeria. This is influenced by the local history and economic situation and the type of cultural and religious socialization within the group. For example, on the Jos Plateau and in parts of Bauchi and Kaduna States, the pastoralists are more oriented towards Salafism, ${ }^{14}$

13 See Mustapha \& Bunza (2014) and Ostien (2018) for detailed overviews of this fragmentation and competition between Islamic movements in northern Nigeria, and of their varied religious practices.

14 Jama'at Izalat al-Bid'ah wa-Iqamat al-Sunnah (The Society for the Removal of Innovation and the Establishment of the Sunnah) - officially called JIBWIS, but popularly referred to as Izala - was founded in Jos in 1978 and gained a strong local following within Fulbe communities on the Plateau. Some influential Izala leaders were or are Fulbe from Plateau and Bauchi. This is explained in some detail in Higazi (2018). 
but more widely the pastoralists have tended towards the darika (Sufi orders), particularly the Tijaniyya. A third category are the numerous pastoralists who are Muslim but do not follow any specific Islamic group. In so far as there is any influence from Sufis and Salafis on their culture and Islamic practice, it is indirect, through mosques and imams in the villages and the wider Muslim community. This is typical in many Fulbe communities, but no specific data exist on the overall proportion who would declare themselves to be 'Sufi' and those who are 'neutral' Muslims. ${ }^{15}$

Photo 9 Cattle market in Illela, Sokoto State, on the Niger-Nigeria border (Photo: Adam Higazi)

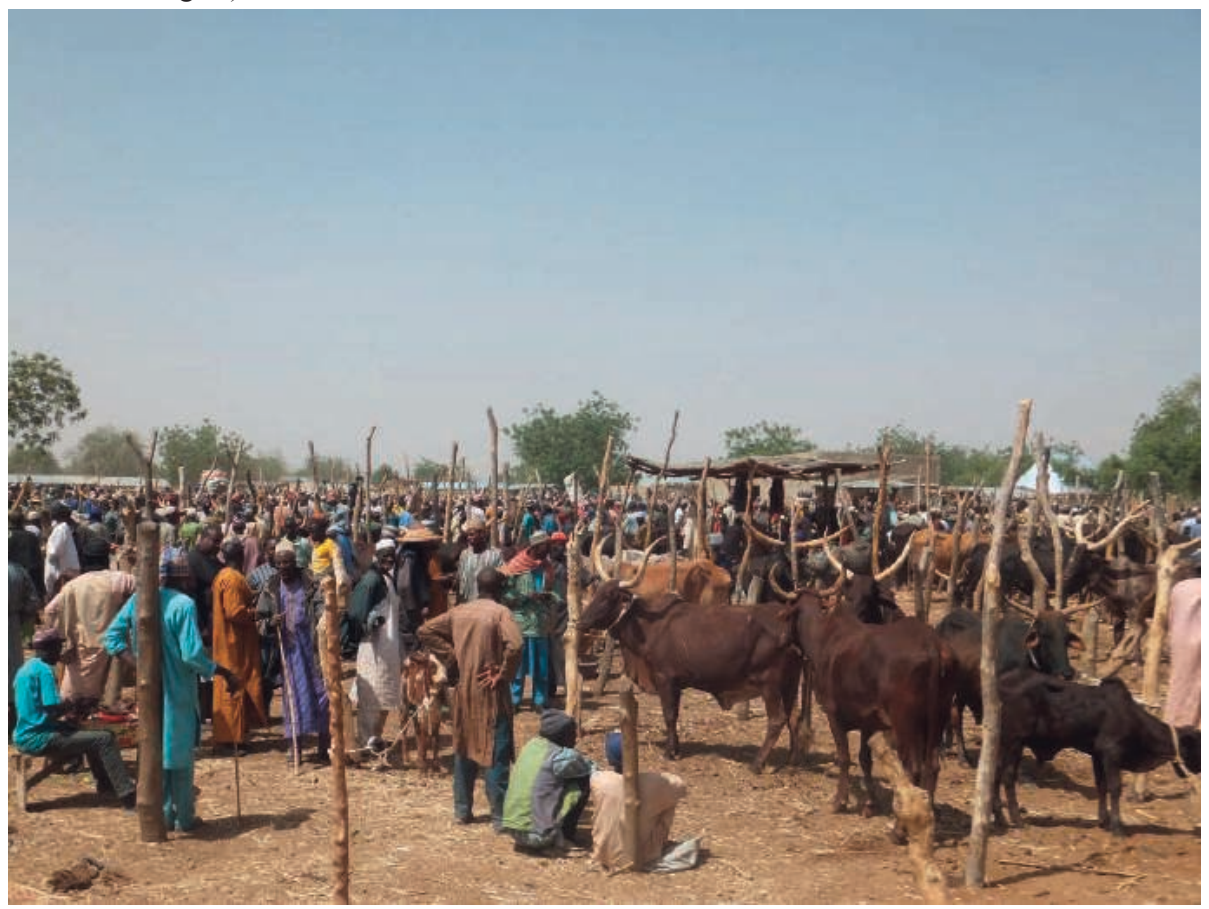

In rural areas of northern Nigeria and Niger, the socialization of Fulbe pastoralists into Islam is largely through a combination of Islamic education which links them to imams and moodibbe (teachers or clerics; malum'en, the Hausa derived word, is also used; sg. moodibbo) in villages and towns - and their

15 The relative size and beliefs of different Muslim groups in northern Nigeria more widely are well analysed by Philip Ostien (2018). 
attendance at congregational prayers in mosques. Pilgrimage (hajj) - to Mecca and to the tomb of Seehu Usmaanu bii Fooduye ${ }^{16}$ in Sokoto (usually before performing the hajj) - is also significant, probably more so in northern Nigeria than in Niger. ${ }^{17}$ The counter-current is the retention of Fulbe cultural ideas and practices, such as around magic and witchcraft and in ceremonial traditions within kin groups and around cattle. However, there is also a consistency and intertwining of many 'cultural' and 'religious' practices; it is only in some instances, not all, that there is tension between them.

\section{Case study 1: Pastoralism and social change in Dakoro, Maradi Region, Niger Republic}

\section{Administration and social composition}

Dakoro is a town and department in central southern Niger in Maradi Region. In 2016 the population of Dakoro Department was estimated at 770,907, of which 87,068 lived in the commune of Dakoro (the town and its adjoining villages). The population of Maradi Region as a whole was 3.8 million, the highest of Niger's eight regions. ${ }^{18}$ Dakoro town is situated $125 \mathrm{~km}$ north of the city of Maradi, which lies close to the border with Nigeria, being only $95 \mathrm{~km}$ from Katsina. Dakoro is semi-arid, with low levels of precipitation interspersed during a rainy season that in some years may last only $1-2$ months. ${ }^{19}$ It lies at the interface of the agricultural and pastoral zones in Niger and once marked the northern limit of agriculture, though cultivators have gradually pushed that limit northwards through the adoption of irrigation systems. There is now a tarmac road from Maradi to Dakoro town, but the tarmac stops in Dakoro town, outside of which the transportation is along laterite roads or rougher bush paths and sandy desert terrain. Transport by use of pack animals and on foot is common, in addition to the use of motorcycles, and, for elites, four-wheel-drive Toyota pickups.

The situation of pastoralists in this region is much influenced by the political and institutional arrangements that govern the rural space. The current institutions

16 This is the Fulfulde rendering of the more common Hausa name of the $19^{\text {th }}$-century Fulani reformer, Shehu Usman dan Fodio. My Fulbe informants referred to 'Seehu Usmaanu'. The etymology is explained by Nelson (1997: 19).

17 Author fieldwork within nomadic Fulbe in Pindiga emirate, Akko LGA, Gombe State, wet season, 2018. Some of my interlocutors there had visited the Shehu's tomb in Sokoto prior to going to Mecca.

18 Le Niger en Chiffres 2016. République du Niger, Ministère du Plan, Institut National de la Statistique. Niamey, November 2016:

http://www.stat-niger.org/statistique/file/Affiches_Depliants/NigerEnChiffres2016.pdf. Accessed 16 April 2018.

19 This was a cause for concern among pastoralists in January 2016, as the past few years had seen short rainy seasons and therefore drought. In subsequent years, such as in 2019, the rains improved. 
developed from those established during the colonial period. As Mohamadou (2009: 3) notes: 'The French colonial authorities established the present department of Dakoro as an administrative and territorial entity in 1947.' The colonial administration made a formal distinction between territorial areas for agriculture and pastoralism, with different leadership and administrative structures in each. As Oxby (2011: 57-58) explains:

the French colonial administration ... made a fundamental distinction between the type of administrative units in the Zone agricole (Agricultural Zone) and the Zone pastorale (Pastoral Zone): in the former, territorially defined administrative units called cantons (cantons) led by chefs de canton (canton chiefs) and under them the various chefs de village (village chiefs); in the latter, ethnically and tribally defined administrative units called groupements or groupes nomades (nomadic groups) led by chefs de groupe (nomadic group chiefs) and under them the various chefs de tribu (tribal chiefs).

Oxby (2011: 74, fn 11) also notes:

The dividing line between agricultural and pastoral zones coincided with the northern limit of cultivation at the time. The distinction between zones was reconfirmed in a 1961 law (Rép. du Niger 2010: 1) that linked it with the $15^{\text {th }}$ parallel North, which transects the national territory of Niger from east to west.

What is now the department of Dakoro contains both pastoral and agricultural zones within it, but there are still differences in their administration, stemming from colonial practice:

When the cantons were created in 1947, the colonial administration divided the Dakoro subdivision into two zones that were divided by the Tarka valley. The cantons in the south were recognised as territories, while the so-called 'residual' area in the north was occupied by nomads, who merely had rights of use over the area. (Mohamadou 2009: 7, fn 4)

The problem is that the delineation of a 'pastoral zone' and 'agricultural zone' tends to be out of sync with the reality of an unstable boundary. The boundary shifts depending on patterns of rainfall and changes in the practice of both pastoralism and agriculture. Farmers and pastoralists are mobile, and what is termed the 'agricultural zone' is really an agro-pastoral zone, with pastoralists and farmers cohabiting, either on a permanent basis or when pastoralists pass through on seasonal transhumance (southwards during the dry season, some of them then crossing the border into northern Nigeria, and northwards when the rains start). In agro-pastoral areas it is also common for households to both farm and rear livestock, although there are also large numbers who exclusively do one or the other. Crucially, farmers have pushed the limit of agriculture northwards into the 
pastoral zone, and as the area of Niger under cultivation has increased, the area of available grazing land has decreased (this is also the general trend in northern Nigeria). Pastoralists have 'user rights' but do not own land in the pastoral zone, and the state has not much protected the land there from agricultural expansion and the cutting of pasture by urban-based traders and farmers. At the same time, the density of cultivation in agro-pastoral areas has increased with demographic growth. Stock routes used by herders to move their animals around for day-to-day grazing and on transhumance are often blocked, while good grazing land is in short supply. This situation has generated competition for land and pasture between pastoralist groupings and between pastoralists and farmers.

The decentralization policy from 2004 was marked by the creation of municipal councils, replacing cantons. The policy was designed to give more power to elected officials at the local level. This had the potential to reduce the power of 'traditional chiefs', but the reality in Dakoro was that the chiefs retained political influence, as they were interconnected with the officials who emerged in the municipalities (Mohamadou 2009). The population of Dakoro commune is cosmopolitan, with a social composition reflecting the diversity of the department as a whole, 'from the Gobirawa and Aderawa Hausa to the Kel Gress and Roumboukawa Tuareg, the Fulani and other groups' (Mohamadou 2009: 12). The groupings with an officially recognized chief in Dakoro town include the Sarkin Peulh, two Tuareg leaders, and the Sarkin Gobir. ${ }^{20}$ The chiefs are the leaders of those communities and they meet regularly to resolve disputes in the commune. There are, however, 12 communes in Dakoro Department in total, ${ }^{21}$ and the administration of the rest of the department rests with the local authorities there, including the chiefs of recognized Fulbe and Tuareg nomadic groupings.

At the time of fieldwork in Dakoro in early 2016, the Fulbe chief, the Serkin Rafi, Alhaji Ahmadu, said he was 87 years old. His family moved from Maradi to Dakoro during the colonial period - probably in the 1930s/40s - and his father was made the first Fulbe chief in Dakoro town. ${ }^{22}$ They came with their cattle - they have bodeeji (red cows) - and according to another source, at that time in Dakoro there were just some Wodaabe and Tuareg nomads and some Europeans. ${ }^{23}$ The town developed after it was established as an administrative centre by the French colonial state. The Hausa population are now thought to form a majority in the

20 Author interview with Alhaji Ahmadu, the Sarkin Peulh, who is head of the Fulbe Serkin Rafi grouping. Dakoro, 29 January 2016.

21 Le Niger en Chiffres 2016. République du Niger, Ministère du Plan, Institut National de la Statistique. Niamey, November 2016: http://www.stat-niger.org/statistique/file/Affiches_Depliants/NigerEnChiffres2016.pdf Accessed 16 April 2018.

22 Author interview with Alhaji Ahmadu, the Sarkin Peulh, op.cit.

23 This was narrated by Alhaji Marafa, aged 75 and a brother to the Serkin Rafi. Interviewed by the author in Dakoro, 28 January 2016. 
town, but it remains ethnically mixed. After the death of their father, Alhaji Adamu's elder brother became chief, to represent the Fulbe community in Dakoro, inheriting the title Serkin Rafi. ${ }^{24}$ Alhaji Ahmadu, a retired tax officer, then inherited the position after his brother's death (in 2012 or 2013, three years prior to our meeting). The family claims a Torod6e lineage, descended from the same line as Shehu Usman dan Fodio.

It was apparent that the traditional authorities in the departmental headquarters of Dakoro town have limited influence in the more rural communes of the department. The Serkin Rafi said that the ardo'en (sg. ardo) (the Fulfulde term for nomadic Fulbe group leaders) in Dakoro Department respect his authority, but he had no direct control over them, and there were different communes in which the population paid its taxes. He would hear about some of the legal cases or if there were disputes he could mediate in, and in instances of drought he had contacted the political authorities - including the regional governor in Maradi. He gave an example of a drought in which the authorities provided assistance to some of the pastoralists. But in general, it is the ardo'en in the rural areas who have direct knowledge of the conditions of the population there. However, it became clear that the ardo 'en have little or no influence within the administration and therefore little power to improve the adverse conditions in which they and their people find themselves.

\section{Religious and cultural continuity and change}

The overwhelming concern of Fulbe pastoralist leaders in Dakoro was the huge difficulty in sustaining their livelihoods (see also Oxby 2014). If there had been perceptible changes in religious and cultural practice, these were viewed as secondary issues, not the main problem of their communities. A perception was that the nomadic or pastoral Fulbe - and pastoralists in Niger generally - were not much affected by the reformist Islam that had gained a following in urban centres such as Maradi and Niamey. ${ }^{25}$ At the time of fieldwork in 2015-2016, nor did the pastoralists and state officials interviewed in central Niger report any influence from jihadist groups that have been recruiting along the borders with Mali and Burkina Faso and in the Diffa Region. However, there were some variations in the responses of different pastoralist leaders on the issue of wider religious trends, probably reflecting varying social conditions in different communities.

24 This is confirmed by Abdoulaye Mohamadou (2009: 4): 'The first chief of the Fulbe grouping was appointed in 1956; he died in 1984 and was succeeded by his son.'

25 This was a widely held view and expressed by community leaders in Dakoro town as well - for example, by Alhaji Marafa, from the family of the Serkin Rafi. He qualified his statement that the reformist group Izala had not penetrated into the nomadic Fulbe by saying that they had not penetrated into the Wodaabe, but that a few individuals from other clans (lenyi) may have joined Izala. 
An ardo representing a Wodaabe group in Sayrou, which he described not as a village but rather a cluster of camps, stated that in his experience there had been no change in Islamic practice among his people. He estimated that he was about 70 years old. They were Muslim but they were not into any of the reformist movements or Sufi brotherhoods seen in towns. Religious knowledge was transmitted via a minority who pursued Arabic studies, reportedly for 2-3 years in Dakoro. ${ }^{26}$ Among the Wodaa6e in Bermo, performative aspects of their cultural traditions were stated to have greatly reduced due to the dire economic condition of the pastoralist population there. ${ }^{27}$ There were cultural rites and traditions that were still known, but if the people were unable to sustain their wealth - particularly in cattle - there was no way or perhaps no mood to perform them (including gerewol, the rite the Wodaabe are famed for in tourist brochures and films). They reportedly send their children for Islamic education with Tuareg teachers in Bermo and to malams in Maradi and Dakoro. The ardo claimed this had led to increased religious observance (a contrasting view to the ardo in Sayrou). ${ }^{28}$

There was a comparable perspective from another elder, Alhaji Abeyo Be'ojian ardo representing Uda'en pastoralists - another Fulbe group (lenyol) specialized in raising sheep - from a clan known as Feroo6e, around Bunde Abeyo village (Dakoro Department). ${ }^{29} \mathrm{He}$ argued the environmental and economic pressures had not led to large changes in the culture. The youths are as they were when he was a youth; young men want to inherit the pastoral lifestyle of their fathers and sustain the family wealth. Some of the cultural traditions remain; they still perform soro, for example (soro had been performed in an area to the north of Dakoro a few months before we met). ${ }^{30}$ The problem was that if conditions continue as they are now, it will be difficult for many of the younger generation to continue in pastoralism. They will be compelled to go out and find alternative

26 This would need further evaluation before being taken as a fact, but his overriding concern in conversation was with livelihood pressures and economic issues. Interview with Ardo Koyeri, a Wodaabe leader from Sayrou. Dakoro, 28 January 2016.

27 Clare Oxby notes that 'Bermo in 1973-4 was a little mission outpost distributing powdered milk to Wodaa6e victims of the great drought of 1972-3. There were no other buildings at all. Also Gadabeji did not exist as a town or market, it was only a nomadic school with a teacher living nearby. This huge increase in population density in the region and the corresponding huge reduction in pasture land in favour of farming and agropastoralism have together rendered the incidence of "drought-linked crisis" so much more frequent.' Email communication with Dr. Clare Oxby, 20 July 2018.

28 Conversation with Ardo Maudé, from Bermo. Dakoro, January 2016.

29 The Feroobe (sg. Feroowo) are an Uda clan mainly in Niger though some are in Nigeria. Feroobe means 'emigrants' and they got the name after a permanent migration (perol), dividing the original group. The other part of the clan they split from are called Kofayanko'en. Source: an Udaajo elder in Babban Gida, Tarmuwa LGA, Yobe State (Nigeria), via phone, 18 April 2020.

30 Soro is a ritual practised by young men or adolescents in some Fulbe clans - it is said to have originated with the Jaafun (de St Croix 1945) - in which those participating are beaten across the chest with a stick (such as tamarind). They are not allowed to flinch or show emotion; thus, it is a test of qualities the Fulbe associate with pulaaku, such as fortitude and courage. 
work, because the wealth is reducing, which will accelerate socio-cultural change. ${ }^{31}$

The ardo described some religious changes among the Uda'en. Until recently they did not follow any specific Islamic organization, but now some of the youths are going into Izala. He cited more than ten in his community, most of whom went to Arabic school in Madawa town (Tahoua Region) and came back with the Salafiinfluenced reformist ideas of Izala. At the time of fieldwork this was not reported to have affected the relationship between youths and elders, but it would need further investigation. In the Jos Plateau case, for example, the spread of Izala among the Fulbe did affect inter-generational relations and the position and role of women in the community and family (Higazi, 2018). The Tijaniyya reportedly had no presence among this group of Uda'en Feroobe. However, those who attend Arabic school may shun certain aspects of Fulbe culture; anyone who goes to Arabic school does not go to soro. Their main concern was not religion or culture, however - it was the lack of rainfall and scarcity of pasture.

There were some variations in religious practice, partly influenced by the type of religious education in different communities. Ardo Abdullahi from Olli, a village north-east of Dakoro town, said pastoral Fulbe children from the Ja'obe or Tukuranko'en undertake their Quranic education in the village; they have Arabic teachers there and none of that community had gone into Izala. The ardo said they had three primary schools and one secondary school in Olli. ${ }^{32}$ Those who finished school tended to leave the village and work outside, while those who did not attend school or did not complete their schooling became pastoralists. In general, where ideas of religious reform have spread into rural areas, it was usually through people who left the villages or camps to pursue Islamic education in towns and then returned with reformist ideas. However, in Dakoro Department it is only a few individuals from pastoralist communities who studied with Quranic teachers linked to Izala or who were influenced by reformist ideas. The more common scenario was for pastoralists in Dakoro to pursue more traditional forms of Islamic knowledge through established networks.

A perceived loss of discipline among the Fulbe was another aspect of social change that elders lamented. A Fulbe leader in Dakoro town claimed their children - Fulbe youths - were responsible for a perceived increase in criminality. He linked this to cultural changes in which discipline and behaviour defined by the idealized norms of pulaaku had been eroded. This had nothing to do with religious reform but was rather linked to wider societal changes and pressures on pastoral livelihoods. There are many Islamic organizations in Dakoro town, including Izala

31 Author interview with Ardo Alhaji Abeyo Be'oji, Dakoro town, 28 January 2016.

32 Author interview with Ardo Abdullahi, Dakoro, 29 January 2016. For more on nomadic education in Olli, see the detailed account in the PhD thesis by Martha Populin (2015). 
and Tijaniyya, but most Fulbe children in Dakoro town go to government schools, not Islamic ones (even if they take Quranic lessons). In this context, greater cultural and religious observance would have been perceived positively, at least by community elders.

\section{Livelihood pressures}

Religious and cultural practices within Fulbe pastoral groups are inevitably affected by the political economy of pastoralism. Changes in pastoral production and the loss of herds lead to changes in the culture and could make young people, particularly, amenable to new religious ideas and influences as they seek alternative work or new places to live. Pastoralists in Niger face serious social and economic challenges, due to what they report as increasingly hostile climatic and environmental conditions, with rainfall perceived to be at a consistently lower level in central Niger now than at any time since the prolonged droughts of the early 1970s and mid-1980s, and vulnerability to these risks due to population pressure and the reduction in pasture land (Oxby 2011, 2014; author fieldwork 2016). Pastoralist leaders in the field described longer dry seasons and shorter rainy seasons now in the area around Dakoro. ${ }^{33}$ A similar finding was made by Clare Oxby (2011: 54) when comparing the situation in central Niger between her first fieldwork in 1973-1974 and a return visit in 2010: 'The big difference is that, whereas a severe drought-linked crisis was exceptional in the 1970s, today it has become recurrent.'

The impacts of low rainfall are compounded by rapid population growth and agricultural expansion, which together have much reduced the availability of pasture and water. ${ }^{34}$ The vulnerability of pastoralists is reinforced by their relative political marginalization. Although some of the leaders of pastoralist groupings are politically engaged and can be influential, most pastoralists are not. They circulate primarily in rural areas at the state's political margins, where their sufferings often go unnoticed, or are ignored. There are also competing interests, between different pastoralist groups, and between pastoralists and farmers, political elites, and in some places agricultural or mining corporations, each laying

33 Climate change is reportedly increasing inter-annual variability in rainfall in the eastern Sahel. The current risks and impacts of low rainfall need to be understood by looking at rainfall patterns over recent years and preceding decades. People's resilience and their ability to adapt and respond depends heavily on their socio-economic circumstances, access to land, wells, and animal feed, and mobility.

34 In 2016 the estimated population of Niger was 20.6 million, but the country has the highest population growth rate in the world. According to the United Nations Population Division, Niger's fertility rate (i.e. the average number of live births per woman at childbearing age) in 2010-2015 was 7.40. In 2016 more than half of Niger's population was under the age of 15. See United Nations, Department of Economic and Social Affairs, Population Division (2017), World Population Prospects: The 2017 Revision. 
claim to land and rural resources. These grievances are comparable in Nigeria and Niger, and more widely in the region.

The problem of low rainfall and scarcity of pasture was emphasized by all the respondents interviewed in Dakoro for this study. An ardo representing a Wodaabe group in Sayrou, a cluster of nomadic camps some two days' walk from Dakoro town, recalled the enduring impacts of the severe Sahelian drought of 1972-1973. He observed that the nomadic population never recovered from that drought. But the main challenge now is the climatic shift they have observed with longer dry seasons; he said the environment was not favourable and did not support pastoralism as strongly as before. ${ }^{35}$ Similarly, an ardo from Olli, to the north-east of Dakoro town, a Pullo from the Ja'obe (or Tukuranko'en) lenyol, explained that in 2015 the rains started in September and ended before the end of October (i.e. it rained for less than two months in the year), and they were not heavy rains. ${ }^{36}$ Pastoralists emphasized that the climatic stress was compounded by other problems, notably lack of access to animal feed (or high market prices), diminishing their resilience.

Alhaji Abeyo Be'oji of the Uda'en Feroobe viewed the number of pastoralists and livestock as being in decline, because it was very difficult for them to survive without artificial feeding during the dry season. ${ }^{37}$ Conditions had become especially bad in the three years prior to our meeting in 2016, for successive dry seasons. The Uda'en are nomadic, renowned for their rearing of sheep and red cattle (bodeeji) and for their transhumance within Niger and between Niger and northern Nigeria. This particular Udaajo leader, however, said that his own people did not migrate into Nigeria. They stayed in the Dakoro area during the dry season when there is no farming - thus, they likely have transitory rather than customary rights over land and water there. When the rains start, they move to Tamayo, near the border between Maradi and Tahoua regions. He said he spends 50,000 CFA per week to feed his herds during the dry season. This significant expense has increased owing to the recurrent droughts and low rainfall. They sell animals to buy feed, reducing the size of their herds. Everyone is at risk of losing livestock, but pastoralists with larger herds are more likely to be able to absorb the losses and sustain a pastoral lifestyle than those with smaller herds, who can easily be pushed out of pastoralism and into poverty.

Those who lose their animals and their family herds may become hired herders (Fulfulde: woynaabe, sg. gaynaako) who tend others' livestock, or labourers in urban areas. The ardo requested that animal feed be sold to them directly, at the government rate, rather than through middlemen who inflate the price. Presently,

35 Interview with Ardo Koyeri. Dakoro, 28 January 2016.

36 Interview with Ardo Abdullahi. Dakoro, 29 January 2016.

37 Interview with Alhaji Abeyo Be'oji. Dakoro, 28 January 2016. 
the middlemen who sell the feed have stores in the towns, and prices are lower there than in the villages. In Niger, the government rate for animal feed was 4,0005,000 CFA per $100 \mathrm{~kg}$ in 2016, but government officials allegedly connive with middlemen and sell it in the market for 10,000-11,000 CFA. For people and not just livestock, getting enough food to eat is a problem; but of course, as pastoralists, their well-being depends on the well-being of their animals.

Nigeria was important both as a source of animal feed and as a market for livestock. ${ }^{38}$ Pastoralists in Niger were affected by the economic crisis in Nigeria that followed the collapse of the oil price in 2015 and by the naira devaluation (the naira had fallen by about half in US dollar terms on the parallel exchange rate market by 2016). In CFA terms, it was not just the naira but also the price of cattle that dropped by close to half. This had knock-on effects even for rural markets in Niger, because so much of the livestock sold by pastoralists there would ordinarily be transported onwards by traders to the large markets in northern Nigeria. ${ }^{39}$ Pastoralists in Dakoro Department sell animals in the Dakoro livestock market, for example, but the marketers then sell a substantial proportion of the animals on in Nigeria. ${ }^{40}$ Much of the population in Dakoro is linked to pastoralism and the livestock trade, so the productivity and profitability of the sector affect the whole department. ${ }^{41}$ This includes people in town who own cattle that are looked after by relatives or by hired herders in the bush.

Pasture has also diminished in the Dakoro area owing to factors other than the climate: first, the extension of agriculture northwards into more traditional grazing areas; second, the phenomenon of farmers and urban-based traders cutting grasses in the bush and then loading them into vehicles to store and sell as animal feed to pastoralists during the dry season. Clare Oxby (2011: 70) also found the cutting of pasture for storage and sale was a major problem for pastoralists in Dakoro and

38 Author field visits to the large Illela livestock market, northern Sokoto State (Nigeria), in 2016 and 2019 indicated that the majority of cattle, camels, and sheep brought there for sale came from Niger and other Sahelian countries through Niger. Pastoralists in the Sahel make a substantial contribution to the supply of livestock in Nigerian markets, though the exact percentage would be difficult to specify without quantitative research across a larger sample of markets.

39 This was reported not just in Dakoro in January 2016 but also in Torodi market in Tillabéri region in April 2017. Prior to naira devaluation, the main buyers in Torodi market were Nigerian traders. At any one time there would be seven or eight large trucks from Nigeria parked along the perimeter of the market, and they would all be filled with livestock which would then be transported via Niamey to Nigeria. Naira devaluation had spoiled the trade, and from that time (2015) at least until 2017 trucks had stopped coming from Nigeria to Torodi market. Author fieldwork in Torodi livestock market, 28 April 2017.

40 Interview with Ardo Abdullahi, from Olli (Dakoro Department), 29 January 2016. This information was corroborated by visits to several livestock markets in Niger and northern Nigeria (as well as Dakoro, these included Say and Torodi in Tillaberi region, Niger, and Illela in Sokoto State, Nigeria, on the border with Birni N'Konni). The cross-border livestock trade between Niger and Nigeria is discussed further by Leena Hoffman and Paul Melly (2015), citing some interesting case study material from livestock markets on the border.

41 Interview with Alhaji Marafa, brother of the Sarkin Peuhl (Serkin Rafi). Dakoro, 28 January 2016. 
Abalak, noting that there is a law against this but it is not enforced. Niger's Pastoral Code makes it illegal for pastoralists to cut grass for their own animals; therefore some are demanding a change in the law, to permit them to cut grass during the dry season for personal use, and to prevent farmers and traders from cutting the pasture on a commercial basis (Oxby 2011).

Photo 10 Herds in Maradi Region, south Niger (Photo: Adam Higazi)

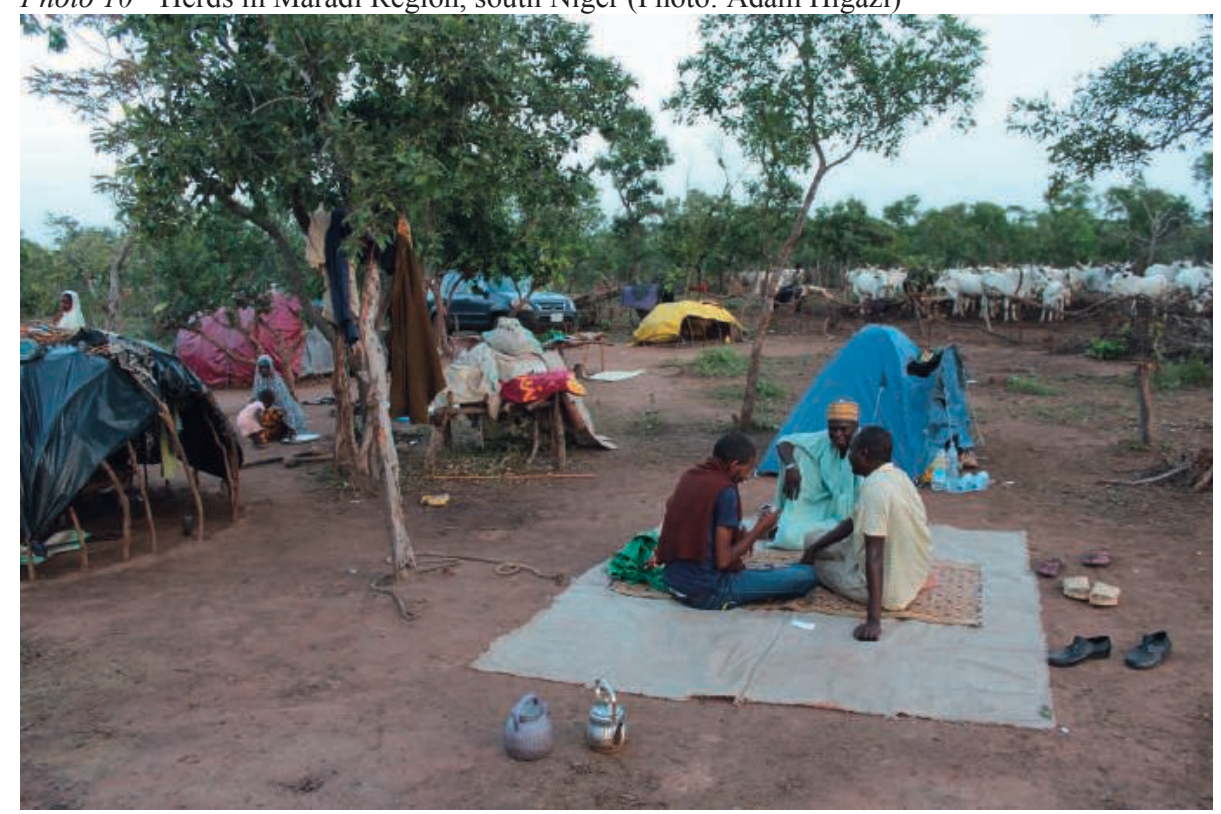

Case study 2: Pastoralism and conflict in Karim Lamido, Taraba State, Nigeria

Karim Lamido local government area (LGA) is situated in northern Taraba State, north-east Nigeria, and borders Adamawa, Gombe, Bauchi, and Plateau States. It is a productive zone for pastoralism and farming, with the River Benue running parallel with the southern boundary of the LGA and tributaries watering other areas. There is a history of migration of both farmers and pastoralists into the area, in the past three decades and over the centuries. Karim Lamido has high ethnolinguistic diversity and a mixed population of Muslims and Christians. The great majority of pastoralists there are Fulbe, belonging to different clans, several of which are in competition with each other (such as the Jaafun and Katsinanko'en). Reference to point of origin, migration histories, and lineage defined the structure 
of authority between Fulbe groups in Karim Lamido and influenced access to pasture and water. There are tensions between pastoralists, between pastoralists and farmers, and between some of the farmers. Only occasionally did these erupt into physical violence. There were instances both of conflict and cooperation, and the relationship between Fulbe pastoralists and farmers varied significantly, as they had better relations with some ethnic groups (e.g. Wurkum) than with others (notably Karimjo). Managing the relationship between the two rural activities of livestock production and crop farming is a major issue in Karim Lamido. An equally important aspect of insecurity in the LGA is kidnapping and banditry. This was most acute in the areas bordering Plateau State, as a spillover from conflicts there, but it has since spread. This criminality comes mostly from within the Fulbe, and it elicited the mobilization of vigilantes linked to the organization Tabital Pulaaku, also Fulbe, to fight it.

\section{Islamic practice and education}

The pastoralists among whom I have carried out fieldwork in Karim Lamido and at their rainy-season camps in neighbouring states (especially Gombe and Bauchi $)^{42}$ generally agree that the level of Islamic knowledge in their communities has increased. In the nomadic camps, the five daily Muslim prayers tend to be observed, and they fast during Ramadan and celebrate the two Muslim feast days. Most Fulbe children, boys and girls, in Karim Lamido receive a rudimentary Islamic education through the practice of almajirci (Hausa: discipleship, where students live away from their parents for a period of Quranic study - see Hoechner, 2018). Nomadic families send their children to 'traditional' Quranic schools (Fulfulde: janngirde Arabiyya or janngirde allooje; sg. janngirde allowal) where students learn to read and recite the Quran using allo boards (rectangular wooden boards the students carry and write on), learning under trees, around fires at night, or in the teacher's house. ${ }^{43}$ Children from the nomadic families studied here usually undertake their Quranic studies in rural areas, generally in villages or small towns, not in cities - but elsewhere some Fulbe families send children to study in

42 I have visited the same Ful6e families most years since 2012, which was the first year I camped with them, in one of their rainy season camps near Alkaleri in Bauchi State. I carried out most of my fieldwork in the wet season camps of the Jaafun, some years for just a few days, some years for several weeks of camping. In 2015 I did part of the rainy season transhumance with the pastoralists, trekking across part of Karim Lamido. I have also carried out research in several other pastoral Fulbe groups, and among farmers, in other states of central and northern Nigeria and in neighbouring countries. This section is based mainly on fieldwork carried out from 2015-2018.

43 In Hausa these schools are referred to as makarantun allo (sg. makarantar allo) - the traditional system of Quranic study in northern Nigeria and other Sahelian countries. In Fulfulde usage in the nomadic groups studied here, a Quranic school is usually referred to simply as janngirde (pl. janngirde) ('school(s)'), whereas Hausa usage is adopted for any Western type of school - makaranta or makarantar boko (pl. makarantun boko). A school, in other words, means a Quranic school, unless otherwise indicated. 
cities or large towns (like Gombe, Bauchi, Yola and Ganye). They become almajirai (Fulfulde: pukara'en; sg. pukaraajo) - Quranic students who live away from their parents during their studies - with imams or Quranic teachers (Fulfulde: moodib6e; Hausa: malamai, sg. malam) known to their parents. ${ }^{44}$ Usually the families send their children to villages in a neighbouring state from their main base, or far enough away to deter the children from returning to camp when they are meant to be studying.

Some of the teachers are Fulfulde-speaking, while others instruct the children in Hausa. The Jaafun Fulbe in Karim Lamido send their children for Quranic instruction in a variety of villages. The choice of where to send the children is made by individual families and depends on their social links and relationships in different areas. One destination is the village of Futuk, in Alkaleri LGA of Bauchi State, where the children study in a Fulfulde-speaking environment. Futuk is situated within their general migration orbit and has been a destination for their Quranic studies for some three generations. Other families within the same pastoral group send their children to other villages. Some of these connections are made during migration, when they camp on grazing land outside villages and forge social connections there - participating in prayers at the mosque, going to markets, establishing ties with traditional leaders. Other links to imams or clerics may be kinship-based. The reliance on known Quranic teachers, in specific villages, suggests the acquisition of Islamic knowledge is carefully managed, not arbitrary.

Within the same Jaafun community ${ }^{45}$ there is another part of the family that sends its children not to Bauchi State but to a Quranic teacher in the village of Kudini in Lau LGA of Taraba State, bordering Karim Lamido. They go to this malam because they say he is a good scholar. ${ }^{46}$ Children (girls and boys) go to him for Quranic schooling from the ages of about 13-15, usually for two to three years, but it can be more. They knew the malam was darika (Tijaniyya), but they did not know much about the specific details of his Tijani practices. They pay the malam for the children's education and upkeep. They give an annual payment of 20,000

44 A key study of Quranic education in northern Nigeria is Hannah Hoechner's (2018) monograph, based on fieldwork in Kano State, particularly Kano city and the small town of Albasu. There are some clear similarities but also apparent differences compared to the situation of almajirai from nomadic families in rural north-eastern Nigeria. Begging for money is more common among almajirai in urban areas, who some perceive as 'street children', compared with the rural areas, where begging for food is often more common. The prevalence of begging among children from nomadic backgrounds in the villages may depend on the wealth and material support given by their families, and in general on the practices of particular Quranic teachers.

45 There are a multitude of clans (lenyi) within the Jaafun - there is a cultural unity, but they are socially heterogeneous. The main ones in the family I studied were Awyaakanko'en and Majanko'en.

46 I recorded this account from a member of the family I stay with, Alh. Mukuru Ajiya Ori, at their wet season camp near Maimadi (a Kanuri village) in Alkaleri LGA, Bauchi State, 4 September 2017. 
naira (about USD 55) per child. ${ }^{47}$ Apart from that, each child, through the malam, is given 7,000 naira (USD 20) per year for clothing. As the malam is given money by the parents, the children are not expected to beg for money, but they may beg for food (as alms), going from house to house in the village. In the villages where these pastoral Fulbe almajirai study they must usually do some farm work or domestic labour in return for being fed. (Begging for money tends to be more the practice of almajirai in urban areas.)

During their studies the children learn some of the basics of reading and writing in Arabic, working their way through the Quran by copying the suras onto their allo boards and reciting it (in Arabic) under the malam's instruction. They also study Islamic practice, including how to pray, and more learned Quranic teachers may teach advanced students aspects of fiqh (Islamic jurisprudence). It is rare for them to acquire functional literacy in the Arabic language, and only some can write Fulfulde in Arabic script (ajami). It is mainly those who continue with their studies to a higher level who may achieve this. After they complete their Quranic studies, they return to their families and continue rearing cattle, if they are boys, or prepare for marriage if they are girls. When children are in janngirde (Quranic school), their families may hire herders to replace their labour - if there are not enough other boys within the household to help. Most families with large herds need hired labour to assist them in any case. The hired herders (woynaabe; sg. gaynaako) may be non-Fulbe, from predominantly farming communities (in one camp I visited, two Wurkun ${ }^{48}$ boys were employed as herders), or from Fulbe families with fewer cattle and available labour.

There are also gifts at different stages of an almajiri's studies. A hen is given to the child after the first stage; then, at the halfway point, when the child has written and recited half of the Quran, the child receives a ram to slaughter as sadaka (voluntary offering or charity). None of these gifts are for the malam. However, at the completion of studies, once the child has recited the whole Quran and has written it down, the malam is given a bull of 2-3 years as a gift, or payment. The families also organize a completion ceremony (Fulfulde: do'a (prayer) or humto jippingo; Hausa: sauka) for the children when they return home at the end of their Quranic studies. This may include the slaughter of a bull to be consumed in the celebration and the giving of gifts to completing students - cattle and/or sheep. That, at least, was the situation of payments and gifts in one nomadic family.

47 This would not be enough to feed and look after a child for a year. It is a token amount and the rest of the cost would be borne by the community's giving of food (as alms) and farm work and domestic work carried out by the almajirai for the malam or other people in the village.

48 The term 'Wurkun' is still commonly used in Karim Lamido by the Fulbe, but this simplifies a more complex ethno-linguistic reality, as explained by Adelberger (1992) - 'it is a generic term comprising linguistically diverse groups' (principally Kulung, Piya, Kwonci and Kode) (p. 8). 
Only a small minority of nomadic children go to government schools. Their formal education is at a low level, partly because of a cultural scepticism towards modern education, but also because the nomadic education system has largely collapsed in Nigeria. ${ }^{49}$ The opportunities for the pastoral Fulbe to send their children to school are limited, even when they really want to educate them. Rural northern Nigeria is generally not well served educationally, with schools or teachers being either absent or of poor quality in most villages. Some of the scepticism towards 'modern' education comes from the experience of pupils spending years at low-quality primary and even secondary schools, finishing with poor literacy and no job prospects, while at the same time being no longer useful as pastoralists or reluctant to return to pastoralism. Better to send children for Islamic studies, they reason, which teaches them how to practise the religion and gives them a moral framework and some status. They complete their elementary Quranic studies more quickly than pupils complete primary school. The logic is that boys can then return to pastoralism and become adept at livestock rearing, while girls can return to help in the household or marry.

Some of the pastoral Fulbe I have stayed with think Western education is deceitful and makes people dishonest (typified by politicians and Nigerian elites), but others were not opposed to it in principle. Some saw its importance but the practicalities were a hindrance, especially the length of time it takes to go through school and the likelihood that at the end the child would not return to pastoralism and could become dependent rather than independent (due to the dire job market in Nigeria). In some areas children would have to be sent to town to attend a government school, where the parents may not have a trustworthy person to look after them. In neighbouring Wase LGA of Plateau State, the family heads in a pastoral Fulbe community called Yaja Lawol wanted their children to be educated in the local nomadic school, which the Fulbe community (not the government) reportedly built in 2001. The teachers were employed by the education authority but they stopped going to work because the Plateau State government was not paying their salaries (this was in the second term of the Jang administration, 20112015, and it is also possible that some teachers were sacked by the government in some cases as they were unqualified - and not replaced). The community then paid the teachers' salaries, but despite this the school closed and fell into disrepair. The Fulbe elders there kept the books and teaching materials and still hoped to restart the school. ${ }^{50}$ These and other examples show that the pastoralists are not

49 A national policy on nomadic education was first launched in 1987. The conception and early implementation is described by Catherine VerEecke (1989). The headquarters of the National Commission for Nomadic Education still exists in Kaduna and there are hundreds of nomadic schools on paper, but in reality only a minority are functional.

50 Author fieldwork in Yaja Lawol, near Kampany, Wase LGA, Plateau State, 3 December 2016. 
entirely resistant to education, Islamic and secular, and many recognize the need to diversify livelihoods in their families.

\section{Tijaniyya influence}

There have been some changes in Islamic practice within Jaafun groups in Karim Lamido. These have been incremental rather than radical, but the effects even over the past five years are observable. The main change is the growing popularity among the Jaafun there of the Tijaniyya - the largest Sufi order in Nigeria. Tijani influence has been propagated by just a few malams from prominent families in the community. The performance of zikiri (Arabic: dhikr, 'mentioning'; rememberence of Allah) is now a frequent nightly routine in some pastoralist camps, with adolescents, especially girls, at the forefront. It involves chanting and recitation (La ilaha illa Ilah - there is no god but Allah), accompanied by improvised percussive instruments such as drums and shakers. The cultural significance is that where the Tijaniyya performance of $d h i k r$ is practised it has replaced the Fulbe tradition of hirde, where children and young adults (male and female) would pass the evening together around the camp, playing games and music and socializing. Fulfulde songs and folktales are hardly heard either. Another point of view was that it was not only dhikr that has reduced the prominence of hirde and folk arts, but also the stressful and conflict-ridden environment the pastoral Fulbe now find themselves in. There is no celebratory mood; even where families are still camping together with their animals, the mood is more subdued. Among the Jaafun in Karim Lamido, Salafi Islam has made virtually no impact. Izala have virtually no following among the Fulbe in this area.

\section{The impacts of Boko Haram and inter-ethnic / religious conflicts}

There was widespread scepticism and opposition towards Boko Haram, which calls itself Jama'at Ahl al-Sunnah li'l Da'wa wa'l Jihad (JASDJ) (The Sunni Community for Proselytisation and Armed Struggle), the Abubakar Shekau-led terrorist group operating in Borno State and contiguous areas of north-east Nigeria. In 2016, the group split in two with the emergence of the Islamic State West Africa Province (ISWAP). Neither of these jihadi groups appears to have followers in Karim Lamido, but the insurgency affected the transhumance patterns of some of the pastoral Fulbe there. As Boko Haram had been raiding and killing Fulbe pastoralists in parts of Borno State, those in Karim Lamido who would previously go to southern Borno for their rainy-season transhumance were compelled to find new rainy-season pastures. A leader of the vigilante group Tabital Pulaaku Jode Jam, whose camp I stayed in for a night in August 2015 outside the village of Jen, Karim Lamido LGA, recalled that he used to spend three months a year in Biu 
LGA, Borno State during the rainy season. In the rainy season of 2017, he returned to Biu, but prior to that he was prevented from doing so by the insurgency. Shekau's men (JASDJ) would steal the motorcycles of villagers and of the nomadic Fulbe. They would also threaten them and demand money, and if they refused to pay, would return and attack, killing people, including, in some cases, pastoralist leaders. Many villages and pastoralist camps were attacked, and for that reason the pastoralists left Biu for a time (and many other areas affected by the insurgency).

When Boko Haram captured most of northern Adamawa in 2014, pastoralists fled from areas around Mubi, Maiha, Madagali, and elsewhere. Some went to southern parts of Adamawa, including Ganye, Jada, and Toungo; others moved across the border into Cameroon. Many of them lost cattle in the process of escaping, partly because it was dry season and the cattle were not strong enough for the journey. In Borno, the nomadic Fulbe were badly hit by Boko Haram and many lost their wealth. They sustained heavy losses and fatalities, but this was hardly reported because these attacks happened in the rural areas away from the security forces and urban-based media. Those who escaped without their livestock became internally displaced populations (IDPs) in Maiduguri, Gombe, Taraba, Adamawa, and elsewhere, or refugees in neighbouring countries. ${ }^{51}$

There is no clear evidence of a causal link between the Boko Haram insurgency in Borno State and the wider Lake Chad Basin, and the sharp increase in violence between pastoralist and farming communities elsewhere in Nigeria. More data are still needed to evaluate what happened to pastoralists who fled the conflict zone in the north-east. It cannot be assumed without evidence that they became involved in conflicts in central Nigeria. Certainly, many were displaced - those who lost their livestock are now in IDP camps or host communities in rural and urban areas of the north-east. Nigeria's security forces, especially the military, have been overstretched due to the demands of fighting the insurgency in Borno and Yobe. This has further weakened security provision in other parts of the country. At the same time, the police presence is light in rural areas, and state authorities tend to be ineffectual or partial in their responses to disputes. Since the 1976 local government reforms, traditional leaders have lost much of their former power, and they struggle to mediate in serious conflicts. The chiefs do still tend to have a local legitimacy and status that political office holders lack, and some actively engage in dialogue between individuals and groups to resolve conflicts. However, while pressures and tensions have increased, the state's presence and capacity in the rural areas has remained weak or has weakened. In Taraba State, political office holders have instigated violence in many areas of the state, by seizing land and stirring up

51 I have interviewed many such IDPs from Fulbe and Shuwa Arab pastoralist communities, recording some of their experiences and confirming that Boko Haram have carried out attacks and raids on them. 
ethnic and religious tensions (generally with a strong anti-Fulani component), and by arming and mobilizing ethnic constituencies.

\section{Conclusions}

Fieldwork for this study points to the serious difficulties pastoralists currently face in northern Nigeria and Niger. At the root of their problems are increased ecological and demographic pressures combined with political marginalization, and, in Nigeria, a high level of stigmatization and popular and political opposition. Whereas the mobility of pastoral groups historically increased their ability to cope with fluctuations in rainfall and pasture, this lifestyle is now under real pressure. Yet, it does still continue and transhumant pastoralism is well adapted to semi-arid conditions and to some of the climatic and ecological changes currently being witnessed. Demographic pressure and reduced access to land, water and pasture have made pastoral production more difficult, but the mode of production (extensive livestock rearing) has also been undermined by the weakening of rural institutions and the loss of much of the infrastructure to support pastoral livelihoods. This has led to social problems within pastoralist communities, particularly among young men, and pushed some into criminality, violence, and drug abuse. This is not however the whole story, as many others seek to find peaceful solutions to their challenges.

There has been an increase in violent conflicts between pastoralists and farmers, especially in Nigeria where mass violence has become common, but conflicts also frequently occur in the agro-pastoral zone of Niger. This study cannot generalize about the situation throughout Nigeria and Niger, but on the conditions of nomadic and semi-nomadic Fulb in around Dakoro (central Niger) and Karim Lamido (north-east Nigeria) based on fieldwork in those areas. Insecurity in those areas was not driven by a 'radicalization' of pastoralists into terrorist groups or militant interpretations of Islam. From the point of view of pastoralists, their main insecurity was in accessing sufficient pasture and water for their livestock, and by extension uncertainties in sustaining and reproducing their herds and flocks for the next generation. Social values and the reproduction of the household were intertwined with the sustenance of the livestock. The political economy of pastoralism has substantial influence on the religious and cultural practices of the pastoral Fulbe in different settings. Islamic values and norms are integrated into their production system, which itself needs to be understood as part of a social system, not only as a 'business'. Cattle for the pastoral Fulbe have social meaning and a cultural, emotional value; they are not viewed only as meat. For state livestock policies to succeed and integrate pastoral populations, these basic facts should be kept in mind. 
There has been a breakdown of governance in rural Nigeria, from local administration to the police and judiciary, but this was less directly apparent in Niger. Competition over rural space has driven some communities into conflict and contributed to unregulated herding practices, the cultivation of grazing land and stock routes, and increased criminality, including banditry and cattle rustling. In Nigeria, there is violence being perpetrated by herders who are now insufficiently supervised or controlled by the social structures and authority systems that would previously have kept them in check. But there have also been many violent attacks against pastoral Fulbe groups in Nigeria, often targeting whole communities. This has led to serious reprisal attacks and cycles of violence. By contrast, local administration in central Niger, while imperfect, was stronger than in the Nigerian case and better able to mediate and resolve disputes before they escalated into large-scale conflicts. The main complaints of pastoralist leaders in Dakoro were the hostile climatic and ecological conditions. They also emphasized insufficient support from government, including the need for regulations to be enforced to protect their pastures, such as against urban-based traders who cut grasses for commercial purposes.

In Islamic practice, there have been some significant changes both in Nigeria and Niger, with possibly greater religious observance among Fulbe pastoralists than a generation ago. However, some elders in Niger reported that there had not been major changes in Islamic practice in their communities. The Tijaniyya had substantially more influence in Karim Lamido, but in general the differences in Islamic practice among the pastoral Fulbe in the two cases were not very wide. A more important difference was in the political and social conditions, as in rural Nigeria the federal structure gives considerable power to Nigerian states and makes it more difficult to limit local identity-based politics. The governance of rural areas has been left to ineffective and weak local government councils. The collapse of security in large parts of rural Nigeria is linked to weak government and maladministration, which makes demographic pressures and competition for land and rural resources harder to manage. These issues are particularly acute in northern Nigeria but they also affect southern Nigeria with the increased movement of herders and livestock southwards. In Niger, the state presence in rural areas was more marked, and in Dakoro there appeared to be less overt discrimination by the state on grounds of ethnicity compared with the Taraba situation.

Assertions that insecurity in rural areas of Nigeria is being driven by the crossborder movements of pastoralists from Niger and other countries may stand up to scrutiny in some areas - for example, border areas of rural Sokoto - but as a general explanation these claims are misleading. They are often political statements that are made without any data. There is cross-border transhumance, but the effects of 
this on security in Nigeria appear to be much exaggerated. That discourse may be an attempt to detract responsibility from the Nigerian state for the rampant insecurity in the country. It could also be to portray pastoralists as 'strangers' without rights, especially in relation to 'indigenous' farmers. While there is mobility in each direction across the Nigeria-Niger border, most of the Fulbe in Nigeria have been there for generations and are full citizens of the country.

In both Niger and Nigeria, religious beliefs and solidarity possibly increased personal resilience in the face of livelihood pressures and perceived risks from prevailing insecurity. Karim Lamido has had conflicts along ethnic and religious lines, but at a lower level to many other parts of Taraba State. In Dakoro, that was hardly the case, because of more religious homogeneity (there was a Christian minority but the population was predominantly Muslim), but still the pastoral Fulbe complained of deteriorating relations with farmers in some areas. The key to resolving such conflicts is likely to be in policies that strive against ethnic and religious discrimination, which intensify production where feasible, support pastoral and farming activities in an integrated way, desist from land seizures, and invest in rural education, economic diversification, and family planning. Presently this does not look realistic, due to limited state capacity in rural areas, and what may be a different set of priorities of political and business elites in relation to land and capital.

\section{Acknowledgements}

I am grateful to Elodie Apard and IFRA for supporting this research and for incisive comments on the paper. I also received very well informed comments and input from Yusuf Habu Na'ango in Jos, Clare Oxby (University of Bern), Hannah Hoechner (University of East Anglia), and Emilie Guitard (CNRS). Abdullahi Umar Eggi was an ideal companion and assistant in the field. Many thanks to all. I am responsible for the final content of the text.

\section{References}

Adelberger, J. (1992), 'The Problem of 'Wurkun': New Evidence for the Clarification of an Enigma in Northern Nigerian Ethnography and Linguistics', African Languages and Cultures 5 (1): $1-9$.

Blench, R. (2018), Towards a Peaceful Coexistence between Herders and Farmers in Nigeria: Conclusions drawn from the field. MISEREOR Dialogue and Partnership Services (DPS), Catholic Secretariat of Nigeria (CSN), Abuja.

Bonfiglioli, A.M. (1988), Dudal: Histoire de famille et histoire de troupeau chez un groupe de Wodaabe du Niger. Cambridge: Cambridge University Press. Paris: Éditions de la maison des sciences de l'homme.

BurnhaM, P. \& M. LAST (1994), 'From pastoralist to politician: The problem of a Fulbe 'aristocracy', Cahiers d'Études africaines 34(133): 313-57. 
DupIRE, M. (1962), Peuls nomades: Étude descriptive des Wodaabe du Sahel nigérien. Paris: Éditions Karthala (second edition).

Gellner, E. (1981), Muslim Society. Cambridge: Cambridge University Press.

Human Rights WATch (2013) "Leave Everything to God": Accountability for Inter-Communal Violence in Plateau and Kaduna States, Nigeria. Report, 147 pp. Online.

HigAZI, A. (2018), 'Rural insecurity on the Jos Plateau: Livelihoods, land \& cattle amid religious reform \& violent conflict'. In: A.R. Mustapha \& D. Ehrhardt, eds, Creed \& Grievance: Muslim-Christian Relations \& Conflict Resolution in Northern Nigeria, pp. 269-307. Suffolk (UK) \& Rochester (US): James Currey.

Higazi, A. \& S. Ali (2018), Pastoralism and Security in West Africa and the Sahel: Towards Peaceful Coexistence. Dakar: United Nations Office for West Africa and the Sahel.

Hoechner, H. (2018), Quranic Schools in Northern Nigeria: Everyday Experiences of Youth, Faith, and Poverty. Cambridge: Cambridge University Press and the International African Institute, London.

Hoffman, L. \& P. Melly (2015), Nigeria's Booming Borders: The Drivers and Consequences of Unrecorded Trade. London: Chatham House (December). Accessed online, 15 April 2018.

IBRAHIM, I.Y. (2017), 'The wave of jihadist insurgency in West Africa: Global ideology, local context, individual motivations', West African Papers, No. 07, OECD Publishing, Paris. http://dx.doi.org/10.1787/eb95c0a9-en

LAST, M. (1987), 'Reform in West Africa: The jihad movements of the nineteenth century'. In: J.F.A. Ajayi \& M. Crowder, eds, History of West Africa, 2nd ed. Vol. II, pp. 1-46. London: Longman.

Mohamadou, A. (2009), 'Decentralisation and local power in Niger'. London: International Institute for Environment and Development (IIED), issue paper no. 150, 24 pp. Translated from French by Lou Leask.

Momale, S.B. (2016), 'Changing Methods of Animal Husbandry, Cattle Rustling and Rural Banditry in Nigeria'. In: M.J. Kuna \& J. Ibrahim, eds, Rural Banditry and Conflicts in Northern Nigeria, pp. 70-110. Abuja: Centre for Democracy and Development. Online.

Mustapha, A.R. \& M.U. BunZA (2014), 'Contemporary Islamic sects \& groups in northern Nigeria', in A. R. Mustapha (ed.) Sects \& Social Disorder: Muslim Identities \& Conflict in Northern Nigeria, pp. 54-97. Suffolk (UK) \& Rochester (US): James Currey.

Nelson, R.W. (1997), Good News for the Fulbe. Hettinger, North Dakota, USA.

ObeYeseKere, G. (1963), 'The Great Tradition and the Little in the perspective of Sinhalese Buddhism', Journal of Asian Studies 22(2): 139-53.

OstiEn, P. (2018), ‘The Muslim majority in northern Nigeria: Sects \& trends'. In: A.R. Mustapha \& D. Ehrhardt, eds, Creed \& Grievance: Muslim-Christian Relations \& Conflict Resolution in Northern Nigeria, pp. 37-82. Suffolk (UK) \& Rochester (US): James Currey.

OXBY, C. (2011), 'Will the 2010 "Code Pastoral” help herders in Central Niger? Land rights and land use strategies in the grasslands of Abalak and Dakoro Departments', Nomadic Peoples 15(2): 53-81.

OXBY, C. (2014), 'Social differentiation of risk: Perceptions of the future in drought-prone Central Niger', Journal des africanistes 84(1): 106-29.

Populin, M. (2015), La scolarisation des enfants nomades et de culture nomade dans le Sahel nigérien Approche historique et comparative entre deux sociétés touarègues: les Iullemmeden Kel Dinnik et les Kel Gress (1944-2011). Paris: EHESS, December 2015.

REDFIELD, R. (1956), Peasant Society and Culture: An Anthropological Approach to Civilization. Chicago, IL: University of Chicago Press. 
RepubliQue Du Niger (2016), Le Niger en Chiffres 2016. Ministère du Plan, Institut National de la Statistique. Niamey, November 2016:

http://www.stat-niger.org/statistique/file/Affiches_Depliants/NigerEnChiffres2016.pdf Accessed 16 April 2018.

Rufa'I, Murtala Ahmed (2017) Cattle Rustling and Rural Banditry in Zamfara State. Center for Peace Studies, Usmanu Danfodiyo University, Sokoto.

St. Croix, F.W. de (1945), The Fulani of Northern Nigeria: Some General Notes. Veterinary Department, Nigeria. Lagos: The Government Printer.

Stenning, D.J. (1959), Savannah Nomads: A Study of the Wodaabe Pastoral Fulani of Western Bornu Province, Northern Region, Nigeria. International African Institute, London: Oxford University Press.

STENNING, D.J. (1966), 'Cattle values and Islamic values in a pastoral population'. In: I.M. Lewis, Islam in Tropical Africa, pp. 387-98. London: Oxford University Press.

United Nations (2017), World Population Prospects: The 2017 Revision. Department of Economic and Social Affairs, Population Division.

Usman, Y.B. (1981), The Transformation of Katsina, 1400-1883: The Emergence and Overthrow of the Sarauta System and the Establishment of the Emirate. Zaria: Ahmadu Bello University Press.

VerEecKe, C. (1989), 'Nigeria's Experiment with a National Programme for Nomadic Education'. Paper 28d, Center for African Studies, The Ohio State University, Columbus, Ohio. 



\section{Part III}

Boko Haram, the trans-nationalisation of a local phenomenon 



\title{
The spread of jihadist insurrections in Niger and Nigeria: An analysis based on the case of Boko Haram
}

\author{
Marc-Antoine Pérouse de Montclos
}

\author{
Ilmin boko yana hana ibada \\ 'The Western school impedes submission to Islam.' \\ Hausa proverb from the British colonization era
}

\section{Introduction}

When trying to understand the spread and the so-called radicalization of Islam in Sahelian Africa, one immediately faces a methodological issue: which point of reference is used? Is there a standardized Islam, one that is 'normal' and peaceful? What would be its geographical centre? Mecca, Kano, Timbuktu, Agadez ... or Ilorin, which was once a hotbed of active proselytism directed towards Yorubaland in the south-west of Nigeria? In the region under study, Islam has historically moved from the north and the east by following trans-Saharan trade routes. Today, however, fundamentalist ideas spread from the south, in this case Nigeria, whose influence can be explained quite naturally by its demographic and economic weight in Sub-Saharan Africa. Should we conclude that religious schools in Kano and Maiduguri have overtaken those of Agadez or Timbuktu?

Another methodological issue is that the focus on today's terrorism tends to overshadow the violence and rigour of yesterday's jihads. In strictly religious terms, however, Boko Haram hardly compares with the rebellion of the Maitatsine sect in 1980 or the widespread looting of the Borno region by the Mahdists of Rabeh starting in 1893, not to mention slavery in the time of Usman dan Fodio's Caliphate after 1804. In this regard, we should stress the ambivalence of Islam regarding social order, for it is both an instrument of submission to God (the original meaning of the word 'Islam') and of struggle in the name of God (with the 
'jihad'). On the one hand, the Quran plays a stabilizing role when it lays the foundations of the rule of law and allows security forces to bind people together by taking an oath not to support Boko Haram. ${ }^{1}$ On the other hand, some surahs legitimize insurgency and are used by jihadists to call Muslims to fulfil their religious duty against the state. Historically, writes Humphrey Fisher, Islam has been used, for example, to establish the authority of the ruling class in Kano, while also being used to defend the rights of the masses in Katsina. ${ }^{2}$

Accordingly, the goal of this study is not to locate the hypothetical centre of influence of radical Islam. Based on field surveys conducted in Nigeria and Niger from 2013 to 2015, the objective is rather to focus on ongoing changes and the modes of dissemination of sermons that challenge the social and political order. In the first part of this chapter, I focus on the main features of Islamization of the region. In the second part, I analyse the geopolitical context that saw the emergence of Boko Haram's precursors at the border between Nigeria and Niger. Historically, the region has seen many rebellions taking place in the name of Islam. Yet, as discussed in the third part, those rebellions did not have global messianic ambitions and, with the exception of Usman dan Fodio's jihad, most of them did not last long, regardless of the high mobility of their protagonists. From this point of view, the fourth part places in perspective the influence that Saudi Arabia may have had on the spread of the Wahhabi doctrine in Sahelian Africa.

In the Lake Chad Basin region, the current situation requires an analysis of local networks that supported Boko Haram's jihad. The fifth part of this chapter focuses on channels through which radical ideas are usually disseminated in the name of Islam: markets, mosques, Quranic schools, prisons, and camps for displaced persons or refugees. These places not only help spread an ideology of protest; they are also spaces of interaction, socialization, and mobilization. It is important to distinguish the two. Thus, some 'disciples' may have decided to fight in the ranks of Boko Haram without adhering to its teachings, while others chose to follow the doctrine of the movement without going as far as taking up arms. In the same vein, it is important to place in perspective the scope and meaning of the sect's online videos, which remain rather rudimentary despite the potential improvements one might have expected given the allegiance of a part of the group to Daesh.

\footnotetext{
${ }^{1}$ In Nigeria, the British were already using Islam to make the emirs in charge of enforcing the colonial indirect rule take an oath of allegiance. Likewise, today, volunteers who enlist in para-governmental militias must take an oath on the Quran to join the ranks of the CJTF (Civilian Joint Task Force). From my observations in the field in the Diffa Region in early 2015, the authorities of the Republic of Niger also used the Quran to encourage residents to denounce the rebels or be cursed. A next step could be to hold public sessions by forcing believers to swear on the Quran their allegiance to the Nigérien government.

2 Humphrey Fisher (1975), 'The central Sahara and Sudan'. In: Richard Gray, ed., The Cambridge History of Africa, vol.4: From c. 1600 to c. 1790, Cambridge, Cambridge University Press, p. 63.
} 
Map 7 Geographical distribution of Pérouse de Montclos’ fieldworks

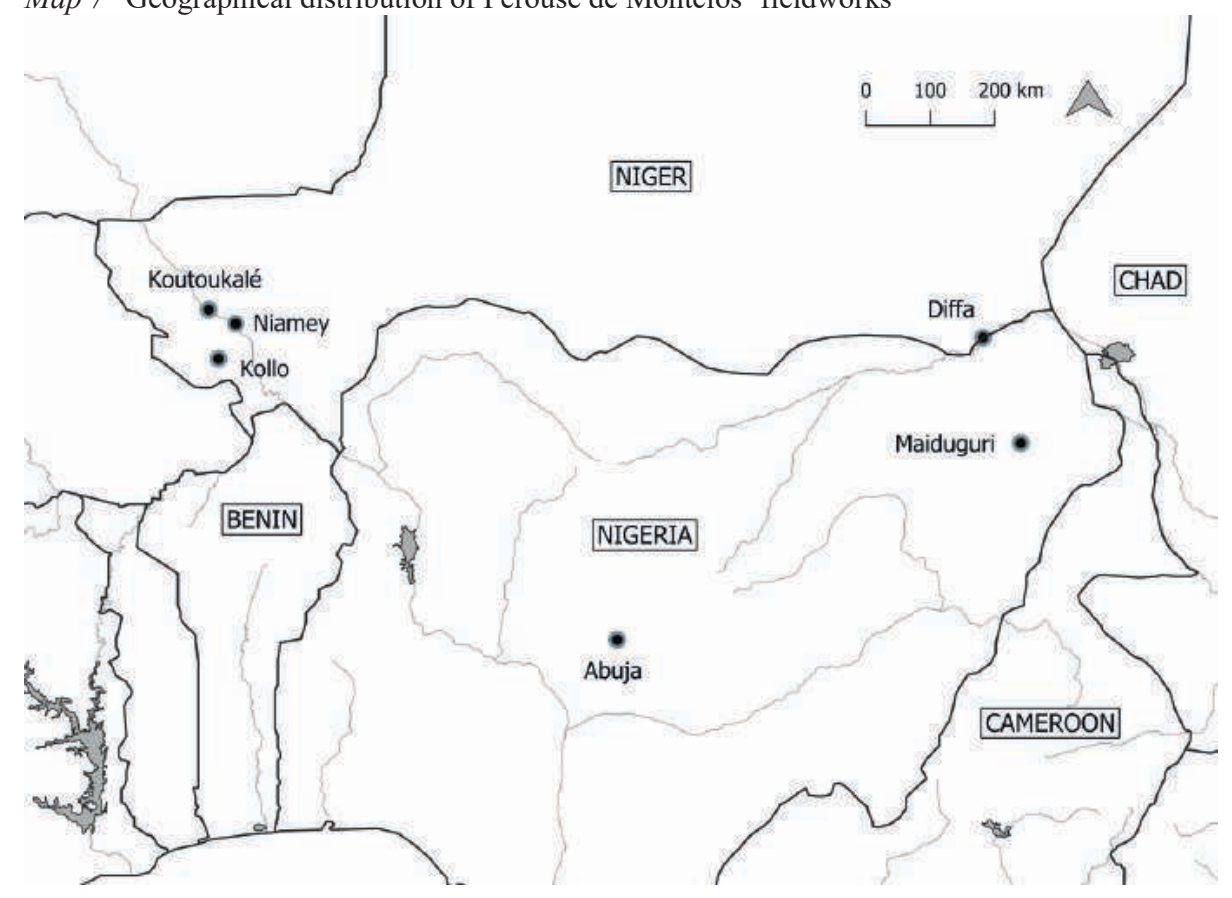

\section{The context}

Historically, the Islamization of the Sahel had little to do with an effort of conquest. While Roman settlers in the Maghreb used a wall (limes) to contain 'barbarians' from the desert, the Arabs sought to spread their civilization without resorting to military campaigns. In the Sahara, traders and preachers found shelter in fortified monasteries and entrenched camps - the ribats, which later lent their name to the 'Almoravid' dynasty in the $11^{\text {th }}$ century - to Sufi 'marabouts' in the $18^{\text {th }}$ century, and to Al-Murabitun ('sentinels') in the $21^{\text {st }}$ century, a terrorist group born from the Al-Qaeda in the Islamic Maghreb (AQIM) movement in Mali. But the Islamization of pagans in Sub-Saharan Africa essentially followed the routes of trans-Saharan caravan trade. In many cases, it actually resulted from very prosaic considerations that were probably less about conversion per se than they were about political allegiance or adherence to a system of values. In the Middle Ages, empires such as that of Mali converted to Islam to assert their authority, seek allies against the Songhai, and belong to 'civilization'. ${ }^{3}$

3 Ulrich Rebstock (2010), 'West Africa and its early empires'. In: Maribel Fierro, ed., The New Cambridge History of Islam. Volume 2. The Western Islamic World, Eleventh to Eighteenth Centuries, Cambridge, Cambridge University Press, pp. 144-58. 
This was followed by the emergence of theocracies whose power was not based on a military jihad but on a mode of government that consecrated the influence of Muslim scholars, such as the Askiya dynasty in Gao, or the Mais of Kanem-Bornu who, in the $11^{\text {th }}$ century, had begun being in contact with Islam through a missionary named Muhammad Mani. ${ }^{4}$ The maraboutism of Sufi brotherhoods became popular later, first with the Qadiriyya as early as the $13^{\text {th }}$ century and then with the Tijaniyya. Meanwhile, Sahelian Islam spread to rural areas as the great medieval empires, founded on caravan trade and merchant activities in cities, dissolved into small agricultural kingdoms. In the $20^{\text {th }}$ century, especially, Sufi brotherhoods became mass movements that managed to meet the challenges of colonization and the market economy by integrating former slaves and new urban migrants. Their sheikhs were actually criticized for exploiting their followers, asking them for money or work time to live off their donations (hadaya) rather than the traditional alms (zakat).

Over time, Islam thus spread beyond educated circles and reached the peasant masses. Indeed, the chain (silsila) of the Sufis' method (tariqa) proved particularly successful in transcending borders, from Senegal to Nigeria, including Mali, Libya, and Sudan. On a continent where the telegraph and the railroad were introduced later than they were in the Ottoman world, Muslim preachers long continued to spread their teachings through the mosque, marriage, and trade. ${ }^{5}$ Salafist groups, which emerged in the 1920s, began to seriously compete with the traditional methods used by Sufi brotherhoods during the oil boom of the 1970s, when the Persian Gulf countries were able to intensify their proselytizing efforts by funding the construction of mosques and by awarding scholarships. Since then, many authors have been concerned with the radicalization of African imams trained in Islamic universities in Saudi Arabia. Some have even claimed that developments in transport and new information technologies have resulted in greater interaction between Africa and the Arab world. ${ }^{6}$

4 Humphrey Fisher (1977), 'The eastern Maghrib and the central Sudan'. In: John Fage \& Roland Oliver, eds, The Cambridge History of Africa, vol.3: From c. 1050 to c. 1600, Cambridge, Cambridge University Press, p. 308.

5 John Spencer Trimingham (1962), A History of Islam in West Africa, Glasgow, Oxford University Press, p. 225 .

6 John Hunwick (1996), 'Sub-Saharan Africa and the wider world of Islam: Historical and contemporary perspectives', Journal of Religion in Africa 26(3): 230-57; Dale Eickelman \& Jon Anderson, eds, (2003), New Media in the Muslim world: The Emerging Public Sphere, Bloomington, Indiana University Press, p. 213. 


\section{The geopolitical situation in the Republic of Niger and Borno State}

In this context, the 'Crescent of Terror' has been a popular concept used to explain contemporary jihads in 'Sahelistan', which are understood as a kind of projection of conflicts in the Arab world. ${ }^{7}$ Surrounded by unstable countries such as Mali, Libya, and Chad, Niger has been examined through this same analytical lens. In the south-east, in particular, its border with Nigeria is now patrolled by armies of the international coalition that was created to combat the terrorist sect of Boko Haram (lit. 'Western education is a sacrilege'). Although Niger is relatively less affected by the onslaught of jihadists than are Libya, northern Mali, and north-east Nigeria, the Charlie Hebdo attack in Paris in January 2015 showed that the country was not entirely immune to violent acts perpetrated in the name of Islam. The issue, for analysts, is that the endogenous dynamics of religious riots have often been overshadowed by the security and media obsession with a global jihad. In reality, marabouts and preachers in Niger did not always rely on models imported from Saudi Arabia, Libya, Mali, and Nigeria to develop a radical discourse against the corruption of both the Muslim community and the elites running a 'secular' state. This is illustrated by the widespread rejection of 'intellectuals' - called yan lakkol in Hausa, referring to the Western 'schools' they attended and which supposedly drew them away from Islam.

The unrest that took place in the south of Niger, its most populated area, highlighted the importance of local dynamics of protest, which had nothing to do with any kind of conspiracy from Nigeria or the Arab world. The border town of Maradi illustrates this in its own way. Mallam Mai Zabura May, for example, who came from Tahoua and settled in Maradi around 1989, did not need to draw inspiration from the Nigerian Izala 'eradicators' when he began to condemn the excesses of secularism and asked that authorities take the rules of Sharia law more into account in public life, without going as far as to openly call for the establishment of an Islamic state. ${ }^{8}$ Al-Koumi Yahaya, a self-proclaimed prophet based in Nigeria, was also a native of Niger, where his virulent sermons against skirts and the licentious music played by local radio stations generated unrest in the Maradi Region and the Dakoro Department in the early 2000s. ${ }^{9}$ Although closer to the Izala's puritanism, Mallam Falalu bin Tassiou differed from the Nigerian model in that he avoided directly opposing the syncretism of Sufi

7 'Sahelistan' is a derogatory term which has been used since the early 2010 s by some thrill-seeking journalists. One of the best examples of this is Samuel Lawrence's book, Sahelistan, Paris, Seuil, 2013, p. 370. In that book, he states that Boko Haram's epicentre is located in Sokoto ... more than a thousand kilometres from Maiduguri!

8 Abdoulaye Sounaye (2009), 'Ambiguous secularism', Civilisations 58(2): 49.

9 Moulaye Hassane, Marthe Doka \& Oumarou Makama Bawa (2006), Etude sur les Pratiques de l'islam au Niger, Niamey, Danida, p. 86. 
brotherhoods. This did not stop him from vilifying the perversion of Western secularism and the deviance of Africanized Islam, leading to his imprisonment in Niamey in 2000 when some of his followers took part in the vandalization of bars in Maradi to protest the organization of fashion shows.

Of course, Muslims in Niger have also been influenced by Nigerian fundamentalists. Both the Sufis and the Izala in Niger, for example, have been opposed to polio vaccination programmes because of rumours spread from Nigeria that accuse Western medicine of trying to sterilize Muslim women. ${ }^{10}$ The expansion of Boko Haram's radical ideas, which originated in the Indimi mosque in Maiduguri, attracts the most attention today. According to stories circulating in Diffa near Lake Chad, the founder of the sect, Mohammed Yusuf, spent his childhood years in the village of Kelakam in Niger. In fact, he was born in Yobe State in Nigeria - either in Gigir in the LGA of Jakusku, or in Na'iyyah in the LGA of Yunusari, according to the different versions available. ${ }^{11}$ But he recruited many Nigériens who had come to study the Quran in Borno State. ${ }^{12}$ Abubakar Kelakam, one of Mohammed Yusuf's first Nigérien followers, was born in the homonymous village; he disappeared after being deported from Damasak by Nigeria in 2009.

Early on, the sect's first members also used Niger as a rear base to proselytize. Even before the emergence of the group which named itself the 'Sunni Congregation for the Propagation of the Prophet's Teachings and Jihad' (Jama'at Ahl al-Sunnah li'l Da'wa wa'l Jihad) in 2010, and then the 'Islamic State in West Africa' (Wilayat Gharb Ifriqiyah) in $2015,{ }^{13}$ a core group of young activists took advantage of the isolation and the porosity of the border area in order to set up a camp in Kanama in the LGA of Yunusari in the north of Yobe State, close to the small Nigérien town of Mainé-Soroa. It is unclear who was the leader of those who

10 Adeline Masquelier (2012), 'Public health or public threat? Polio eradication campaigns, Islamic revival, and the materialization of state power in Niger'. In: Hansjörg Dilger, Abdoulaye Kane \& Stacey Langwick, eds, Medicine, Mobility, and Power in Global Africa, Bloomington, Indiana University Press, pp. 213-40.

11 Muhammad Sani Imam \& Muhammad Kyari (2011), 'Yusufuyya and the Nigerian State: Historicizing the Dynamics of Boko Haram Phenomenon', Kaduna Journal of Liberal Arts 5(1); Ahmad Murtada (2013), Boko Haram in Nigeria: Its Beginnings, Principles and Activities, Kano, Bayero University, Salafi Manhaj, p. 3.

12 They would rather go to Sokoto for mystical initiation or to Zaria and Katsina to learn Arabic. Sokoto thus attracted more than 11,000 Nigérien Islamic students in the early $2010 \mathrm{~s}$, almost $5 \%$ of the children sent to itinerant Quranic schools within Sokoto State. Such a proportion was however much lower when moving away from the border, towards Bauchi, for example. See Peter Clarke (1978), 'Islam, education and the development process in Nigeria', Comparative Education 14(2): 134; Research Triangle Institute International (2015), Nigeria Reading and Access Research Activity (RARA): Survey of Itinerant Qur'anic Learning Centers and Almajiri Learners in Bauchi and Sokoto States, Washington, United States Agency for International Development Nigeria (USAID), p. 2.

13 Boko Haram ('Western education is a sacrilege') is a derogatory term given by the local press to Mohammed Yusuf's followers during the insurrection of July 2009. Previously referred to as Yusufiyya, they first used the term 'Jama'at Ahl al-Sunnah li'1 Da'wa wa'l Jihad' to sign their action in a leaflet distributed at the time of the attack on the Bauchi prison in September 2010. 
were then called the 'Nigerian Taliban', the 'Mujahideen' fighters, the 'Muhajir' emigrants, or the 'al-Takfir wa'l-Hijrah group'. Security sources mention a certain Muhammad Ali or Usman Ibn Abdulkadir. ${ }^{14}$ The nicknames 'Abu Umar' and 'Mullah Umar' have also been mentioned, as well as the presence of a student from the University of Maiduguri, Aminu Tashen Ilimi, who, like Muhammad Ali, allegedly left Mohammed Yusuf because he found him to be too 'liberal'. ${ }^{15}$ Witnesses, however, speak instead of Ahmed or Hamit. ${ }^{16}$ In any case, it seems that neither Mohammed Yusuf nor Abubakar Shekau were part of that group, whose base is believed to have initially consisted of about twenty students from the University of Maiduguri.

Driven out of Geidam and then Jajibrili in Yobe State, the 'Nigerian Taliban' settled in rural Kanama to take advantage of cover provided by the vegetation of the Yobe River valley and the possibility of fleeing to Niger in case of problems. ${ }^{17}$ Governed according to the strictest rules of a Salafist and sectarian Islam, their 'holy city' aimed at creating an autonomous enclave and accommodated up to one hundred people, including women and children. But they soon came into conflict with indigenous people over fishing rights. In their version of Sharia law in the $19^{\text {th }}$ century, the jihadists of the Sokoto Caliphate had indeed stated that all rivers belonged to the public domain, unlike wells dug on private land or desert oases and tanks of rain water, which were shared on a community basis. ${ }^{18}$ Of course, the residents of Kanama disliked this Islamic form of communism and asked the 'Taliban' to leave.

While most of them returned to Maiduguri, about twenty of them refused to comply and fled to Niger. In late November 2003, they returned to Kanama with guns, bows, arrows, spears, machetes, and home-made grenades to attack the police station, where they killed an officer and took possession of weapons and a vehicle. Anti-riot Mobile Police units, sent with trucks as reinforcements, failed to chase away the rebels, in a battle that killed half a dozen people in total. Dispatched from the barracks of Nguru, in a village that has since then been deserted by the population, the army took over and killed seven Taliban. ${ }^{19}$ The survivors sought

14 Celestine Oyom Bassey \& Charles Quarker Dokub (2011), Defence Policy of Nigeria: Capability and Context, Bloomington (IN), Author House, p. 405. Muhammad Ali reportedly later succumbed to his injuries in January 2014.

15 Isa Umar Gusau (2 Aug. 2009), 'Boko Haram: How it all began', Daily Trust; Ahmed Salkida (1 March 2009), Sunday Trust.

16 Interviews in Maine-Soroa, February 2015.

17 Summary of an interview conducted in Kanuri with Kanama district chief Alhaji Lawan Zarami, who fled to Mainé-Soroa, February 242015.

18 Chafe, Kabiru Sulaiman (1999), State and Economy in the Sokoto Caliphate: Policies and Practices in the Metropolitan Districts, 1804-1903, Zaria, Ahmadu Bello University Press, p. 79.

19 According to the military, security forces also took about fifty prisoners, including two women and a four-year-old child. A total of 18 people reportedly died in December 2003, including two policemen in Kanama and Geidam. See IRIN, 25 January 2004; Anna Borzello (14 January 2004), 'Tracking down Nigerian Taleban's sect', BBC News. http://news.bbc.co.uk/2/hi/africa/3393963.stm 
revenge by raiding and burning the police stations of Geidam and of Bayamari in the LGA of Bosari, then that of Babban Gida in Tarmuwa. Each time, they seized the opportunity to get their hands on weapons, ammunition, and vehicles without any casualties, since the police had previously deserted those places. Before retreating to Borno, in early January 2004, insurgents also killed another police officer in Damaturu, the administrative capital of Yobe State.

Photo 11 Banner with pictures of Boko Haram suspects (Photo: Marc-Antoine Pérouse de Montclos)

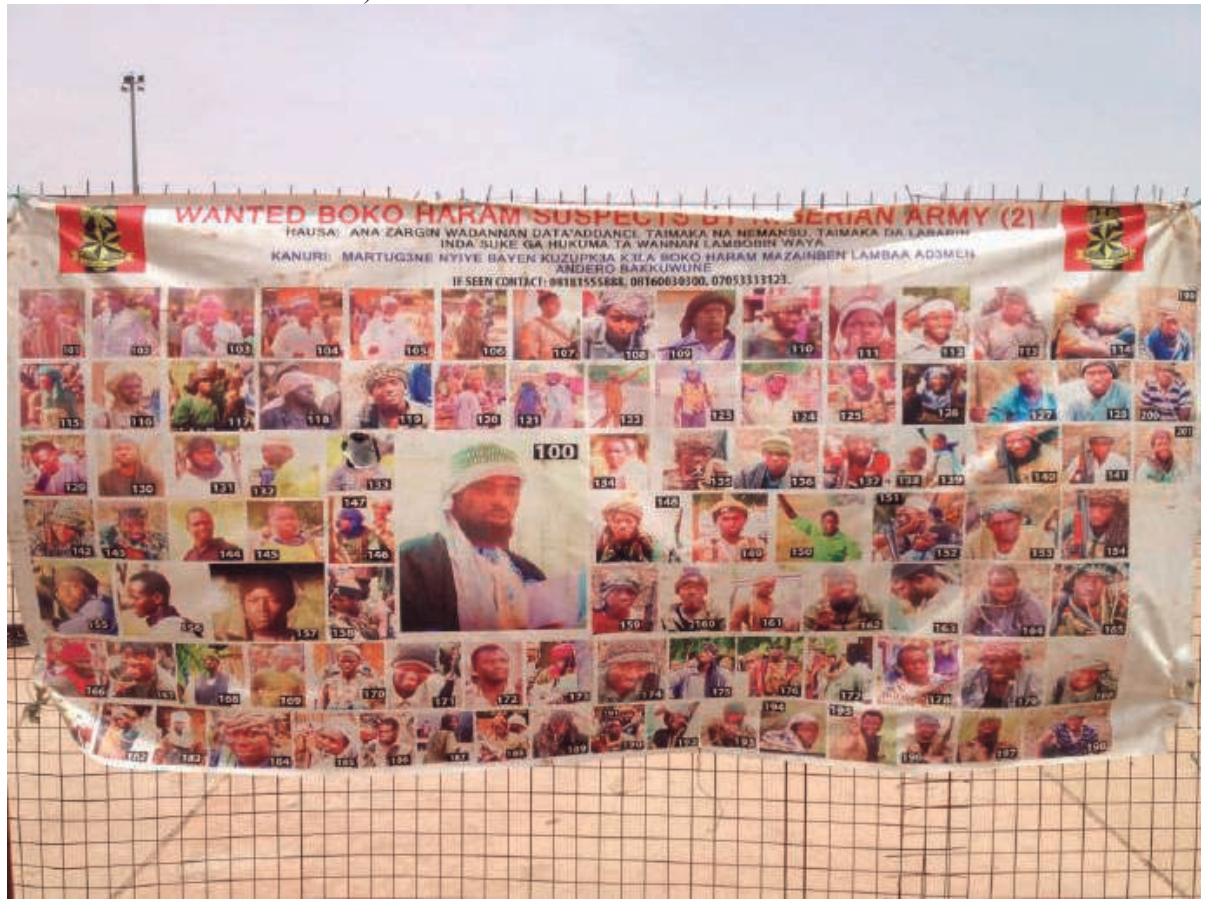

What happened next is more widely known and does not need to be repeated in detail. What should be remembered is that after further skirmishes with Nigerian security forces around the Mandara mountains at the Cameroonian border until October 2004, ${ }^{20}$ the survivors of the battle of Kanama went to Maiduguri to join the ranks of Mohammed Yusuf's followers in the Indimi mosque and then the

20 The LGAs of Kala-Balge, Bama, and Gwoza were the most affected. In Kala-Balge in October 2004, insurgents kidnapped a dozen policemen, who are still missing. In Gwoza, they allegedly lost 28 men during a battle with the police in September 2004. The first recorded attack in Cameroon took place much later, in April 2012, when the insurgents burglarized the Amchide police station to steal weapons. 
railway station. At that time, the movement was already looking to expand to Diffa and Mainé-Soroa. But it was the extrajudicial execution of Mohammed Yusuf in July 2009 that gave Niger a true strategic dimension as it welcomed and accommodated followers that had been driven out of Nigeria by military repression. In December 2011, the authorities thus uncovered a plan to attack the city of Diffa. In September 2012, they dismantled a cell of five Boko Haram members who had settled in Zinder in order to procure weapons. ${ }^{21}$ Since then, the situation has continued to deteriorate. Regularly under attack, the border area was turned into a battlefield when, early in 2015, an anti-terrorist coalition was formed by the armies of Nigeria, Niger, Chad, and Cameroon.

\section{Porous borders or global Islam?}

Besides its military aspects, the extreme case of Boko Haram raises questions about the circulation of ideas among Muslim fundamentalists in Nigeria and Niger. In this regard, we should distinguish the effects caused by proximity to a permeable border, on the one hand, from the global ambitions of a proselytizing Islam, on the other. Historically, the current territories of Nigeria and Niger have experienced many jihads. Usman dan Fodio (1754-1817), heroic figure and founder of the Sokoto Caliphate, was born in the Republic of Niger in Maratta, near Galmi, about 50 km from Birnin Konni. A lesser-known Fulani from Niger, Mallam Dubaba, aka 'Sheriff ad-Din', also mobilized Hausa, Kanuri, and Shuwa Arabs to launch a holy war against Baghirmi, where he was killed around 1875.

Because of their mobility, pastoralists and traders played an important role in the dissemination of this military Islam. In today's northern Cameroon, for example, the Fulani who fled the Kanuri of the Borno Empire during Usman dan Fodio's jihad were the first to establish a new Emirate in Maroua in $1808 .^{22}$ In the 1880s, still in northern Cameroon, Hayatu bin Said, a Mahdist opponent to the Sokoto Caliphate, then set up a camp at Balda, which attracted people from as far away as Sudan. ${ }^{23}$ At the time, he made an alliance with famous warlord Rabeh, who conquered Baghirmi in 1892 and Borno in 1893. Defeated, the Shehu of Borno was executed near the Yobe River along today's Nigérien border. His successor took refuge in the Sultanate of Damagaram near Zinder, while Rabeh set up his palace near Dikwa, where Boko Haram has a strong presence today. ${ }^{24}$

21 Testimony gathered by the author in the prisons of Koutoukalé and Diffa in 2014 and 2015.

22 Martin Njeuma (1994), 'The Usmanuya system, radicalism and the establishment of German colonial rule in Northern Cameroon, 1890-1907', Paideuma 40: 116.

23 Martin Njeuma (1971), 'Adamawa and Mahdism: The career of Hayatu Ibn Sa'id in Adamawa, 18781898', The Journal of African History 12(1): 61-77.

24 Mohammed Kyari (2006), Borno in the Rabih Years, 1893-1901: The Rise and Crash of a Predatory State, Maiduguri, University of Maiduguri, p. 207. 
In the early $20^{\text {th }}$ century, the border drawn between the British and French colonies of Nigeria and Niger did not put an end to the incursions of rebels acting in the name of Islam. Waged against the French in Kobkitanda in the Niger region of Dosso in early 1906, the revolt of Alfa Saibu, a blind, mystical, and millenarian ventriloquist-cum-marabout, is probably the best known, while many others have fallen into oblivion. Defeated, its leader fled to Nigeria, where he was known by the Hausa name of Shaibu dan Makafo (lit. 'Shaibu the Blind'). There, in the camp of Satiru, he joined the ranks of Mallam Isa, another Mahdist rebel who had taken over from his late father, Mallam Maikaho, who had died in prison after proclaiming himself Mahdi in January 1904. Composed of peasants, prisoners, runaway slaves, and scholars, many of whom were from Gobir, the 'Satirawa' defeated British troops in February 1906, before being crushed and having their camp razed to the ground a month later. ${ }^{25}$ As for Alfa Saibu, he was beheaded on the market square in Sokoto in March 1906.

The uprisings of Kobkitanda in Niger and of Satiru in Nigeria share strong similarities in their objectives, their modes of propaganda, and their strategies. Alfa Saibu and Mallam Isa knew each other before the start of their revolts, which were scheduled to take place on the same dates. Both mobilized poor people from various ethnic and social backgrounds who wanted to evade the power of traditional authorities and the Fulani Sokoto Caliphate. Like Kobkitanda, Satiru was a place of refuge, whose name actually came from the Arab satara and the Hausa soutoura, which both mean 'to protect'. Contrary to what the French and the British believed, however, the revolts did not result from a large transnational and pan-Islamist conspiracy fomented by the Qadiri, the Ottomans from Libya, and their German allies. ${ }^{26}$ For Kimba Idrissa, they were primarily protests against abuses by local authorities. ${ }^{27}$ They were neither a reaction to Western modernity nor an ethnic struggle to defend a traditional aristocracy that had lost its spiritual, judicial, and economic power because of the abolition of slavery and the imposition of a new colonial order.

From this perspective, crossing the border between Nigeria and Niger played a rather limited role and had nothing to do with the internationalization of a global jihad or an anti-colonial revolution. It was just helpful in providing an escape from the British or French justice systems when they failed to negotiate a right of

25 Paul Lovejoy \& Jan Hogendorn (1990), 'Revolutionary Mahdism and resistance to colonial rule in the Sokoto Caliphate, 1905-6’, Journal of African History 31(2): 217-44.

26 Following an assassination attempt on the Zinder district commander in March 1906, the case was nonetheless used to justify a military expedition to occupy Agadez. See Christopher Harrison (1988), France and Islam in West Africa, 1860-1960, Cambridge, Cambridge University Press, p. 48.

27 Kimba Idrissa (1994), 'Les révoltes paysannes et anticoloniales dans l'Ouest du Niger, 1905-1906', Paideuma 40: 196 \& 208. 
prosecution or an extradition. ${ }^{28}$ Occasionally, it also protected people fleeing Sokoto. ${ }^{29}$ But the 'Islamist' revolts of the time were usually very local, as with Miji-n-Aoua, a fallen Hausa chief. His small rebellion was probably organized from Katsina and led to the murder of a British officer in Nigeria and of a French expatriate in an attack against the Tessaoua prison in Niger in June 1927. Obsessed by the idea of a large Mahdist conspiracy, the British saw in it a matter of international proportions when in fact it was a mere act of revenge. ${ }^{30}$

Such incidents continued to take place after the independence of Nigeria and Niger in 1960; but they were also short-lived, rarely documented, and soon forgotten by everyone except for a small circle of elders at a very local level. We could mention, for example, the 1967 revolt of Youra Bourdou, a Fulani prophet from the village of Ladou, located south of Geidam in today's Yobe State. Nigerian authorities were mobilized by the Biafra War at the time, nearly a thousand kilometres away, and called up the Republican Guards of Niger to suppress the rebellion. A goumier from Toubou, named Yunus, killed the troublemaker and, according to legend, was made to commit suicide shortly thereafter by the magical powers of his victim. In the region of Geidam, still, elders also speak about the case of a healer of the Tijaniyya in the village of N'gourou who would claim he could fly like an angel in order to cheat Fulani herders before being killed in Kano around 1982.

In such a context, Boko Haram's rebellion seems to have moved to a completely different level. On the one hand, insurgents were actually able to take advantage of international borders in the region to escape Nigerian security forces. ${ }^{31}$ On the other hand, they used a global rhetoric to challenge the state by borrowing from the phraseology and the iconography of the Arab jihadists of al-Qaeda and Daesh. Referring to a world revolutionary Islam is also what fundamentally differentiates Boko Haram from previous millenarian insurgencies which ravaged northern Nigeria, including the Maitatsine revolts of 1980-1985. That being said, it is not incompatible with the deep local roots of a sect whose first model was the Sokoto Caliphate. ${ }^{32}$ In its genesis, Boko Haram was a proselytizing movement preaching

28 Nigeria and Niger have also served as a refuge for traditional leaders who were sued by colonial authorities over a variety of cases, ranging from slave trade to sedition. See Daouda Mamadou Marthé (2015), Dans les marches nord du Borno (Bornou). Les mutations politiques coloniales dans l'Est nigérien (1893-1960), Paris, L'Harmattan, p. 294.

29 Chased by Usman dan Fodio's troops, the Hausa in Gobir, for example, found asylum in Maradi, where they were welcomed by their former opponents from Katsina. Accused of witchcraft and removed from power by his peers, the Sultan of Sokoto, Muhammad Tambari, then fled to Niger in 1930. See Guy Nicolas (1979), 'Détours d'une conversion collective. Ouverture à l'Islam d'un bastion soudanais de résistance à une guerre sainte', Archives de sciences sociales des religions 48: 83-105.

30 Jean Chapelle (1987), Souvenirs du Sahel: Zinder, lac Tchad, Komadougou, Paris, l'Harmattan, p. 80.

31 Marc-Antoine Pérouse de Montclos (2015), 'Boko Haram et la souveraineté du Nigeria: une histoire de frontières', Hérodote 159: 58-75.

32 Abdulbasit Kassim (2015), 'Defining and understanding the religious philosophy of jihādī-Salafism and the ideology of Boko Haram', Politics, Religion \& Ideology 16(2-3): 173-200. 
$d a$ 'wa, unlike al-Qaeda, which has always been a logistical platform only, initially at the service of Afghan mujahideen.

\section{From Arabic to Kanuri}

Close attention should also be paid to the way Mohammed Yusuf and his successor Abubakar Shekau disseminated their teachings and mobilized followers. ${ }^{33}$ A point of clarification should first be made. Indeed, the academic literature on terrorism tends to highlight the devastating impact of Saudi Wahhabism on contemporary jihadist movements, ${ }^{34}$ therefore suggesting that African Islam is but a mere receptacle for the seditious ideas of fundamentalists in the Gulf countries. ${ }^{35}$ Yet, Arabic is not the language of preaching in areas where very few people can understand it. ${ }^{36}$ Along the border between Niger and Nigeria, Hausa is the main language used for Quranic exegesis ( $t a f_{\text {sir }}$ ) and large religious gatherings (wa' azin kasa). In fact, it has gradually replaced Fulfulde as a sacred language. ${ }^{37}$ From Sokoto to Kano, Fulani jihadists eventually learned Hausa and gave up their native language by integrating indigenous cultures instead of imposing their vision of the Quran. Meanwhile, Hausa migrants and merchants spread their language in neighbouring countries. In Chad, for example, they married Arabic-speaking women, and their children learned only Hausa: a process that the French supported to counter the influence of the Senussiyya Order from Libya. ${ }^{38}$

In the case of the Kanuri of Borno, Boko Haram recruited mostly on the basis of a linguistic and ethnic community. 'Trust' (amana in Hausa and Kanuri) was crucial in the spread of a movement. In a way, Mohammed Yusuf's discourse also flattered the Kanuri who were proud to be the first in the region to have converted

33 On the different phases of the sect's recruitment process, see Marc-Antoine Pérouse de Montclos (2016), 'Boko Haram: A jihadist enigma', Small Wars \& Insurgencies 27(5): 878-95.

34 For a critique of the excesses of those theories, see Marc-Antoine Pérouse de Montclos (2015), 'Du Nigeria au Maghreb: le chaînon manquant entre Boko Haram et Al-Qaïda', Maghreb-Machrek 222: 111-22.

35 Paradoxically, this view is in line with the classic literature on the topic, which presents African Islam as marginal and separated from the Muslim world by the Sahara 'barrier'. For an example of this, see John Spencer Trimingham (1962), A History of Islam in West Africa, Glasgow, Oxford University Press, p. 262.

36 At Nigeria's Independence, even the Northern Region's head of government, the Sardauna of Sokoto, did not speak Arabic. As a result, he had to be represented by Abubakar Gumi, his Qadi and the future founder of the Izala, during the inauguration of the Arab League in 1962. See John Hunwick (1996), 'Sub-Saharan Africa and the wider world of Islam: Historical and contemporary perspectives', Journal of Religion in Africa 26(3): 239.

37 Even before colonization in Katsina, for example, Hausa prisoners were so integrated into Islam that their captors had no right to sell them as slaves and therefore preferred to cut their tongue to prevent them from identifying themselves! See Louis Brenner \& Murray Last (1985), 'The role of language in West African Islam', Africa (London) 55(4): 444.

38 Guy Nicolas (1978), 'L'enracinement ethnique de l'islam au sud du Sahara. Etude comparée', Cahiers d'études africaines 18(71): 353-58. 
to Islam, as early as the $11^{\text {th }}$ century, and to have created a homogeneous community of believers, in contrast with the Hausa and their pagan minorities, the maguzawa. ${ }^{39}$ However, Boko Haram always adopted a pan-Islamist position and never made any ethnic claims. Using Kanuri meant adapting to local constraints in order to recruit followers within a population that did not speak Arabic. ${ }^{40}$

The sacred language of the Quran thus formed a linguistic barrier that hindered the spread of Islam. In the $19^{\text {th }}$ century, for example, only a handful of scholars could read and write in Arabic; many marabouts simply practised geomancy in the sand and without books. For a long time, the mystical and hermetic orders of Sufi brotherhoods limited the teachings of their method (tariqa) to an elite made up of Muslim clerics. Their ulema jealously sought to keep a monopoly on knowledge; their main concern was to preserve the purity of the Quran, not its dissemination or its translation into Hausa. That is in fact the reason, in 1972, Muammar Gaddafi founded the Islamic Call Society (al-Dawa al-Islamiyya), in order to spread the teaching of Arabic, of the Quran, and of Sharia law all at the same time.

Another important point is that the jihadists in the Sahel did not always need foreign models to challenge secular powers. Historically, for example, Usman dan Fodio fought to create an independent Islamic state, without pledging allegiance to the sultan of Constantinople or the Sharif of Mecca. ${ }^{41}$ Being a follower of the Qadiriyya, and not of the Wahhabi movement, he refused to renounce the cult of the saints and soon broke away from the too-radical teachings of his mentor, who was based in the Aïr mountains. He also did not draw inspiration from the Sudanese Mahdism, even though some saw him as a sort of Messiah, a belief which he refrained from refuting too vehemently in order not to disappoint his followers. The dissemination of Wahhabi ideas in Nigeria was in fact posterior to Usman dan Fodio's jihad. It dates from the second half of the $19^{\text {th }}$ century when, for example, a certain Mallam Ibrahimu was executed in Kano in 1870 because he advocated a departure from the Maliki school to join the Saudis' Hanbali school; his followers then fled to Lagos, where they were given the Hausa nickname of 'forgers'

39 Called arna or azna (sg. arne) in Niger and maguzawa (sg. ba maguje) in Nigeria, Hausa animists get their name from an Arabic and Persian word, majus, which refers to the status of 'protected' people, dhimmi, in Islamic lands. Heavily influenced by Islamic culture, they speak the same language as the Muslim Hausa (called yan riga because they wear boubous) and they equate Ubangiji, their supreme deity, to Allah. Mostly found in rural areas, they are different from other villagers in that they do not seclude their women; they do not follow the ablution rituals; they allow teenagers to flirt; and they drink millet beer. See Jerome Barkow (1973), 'Muslims and Maguzawa in North Central State, Nigeria: An ethnographic comparison', Canadian Journal of African Studies 7(1): 59-76.

40 The locals are generally multilingual and the Kanuri language keeps losing ground, even in Maiduguri, where Hausa, which is used as a language of commerce, may have become dominant.

41 Mervyn Hiskett (1994), The Sword of Truth: The Life and Times of the Shehu Usuman dan Fodio, Evanston (Ill.), Northwestern University Press, p. 137. 
(shargidi). ${ }^{42}$ These movements nonetheless remained furtive, and it was not until the 1970s oil boom that Izala fundamentalists emerged under the aegis of Abubakar Mahmud Gumi a sheikh trained in Saudi Arabia.

The true global space that is Mecca, as well as the Islamic University of Medina, certainly played a role in framing the doctrine of the 'Society for the Eradication of Evil Innovations and the Re-establishment of Orthodoxy' (Jama'at Izalat alBida wa Iqamat al-Sunnah), which is the Izala's full name. Close to the Saudis, Abubakar Gumi for example used his position in 1973 to ban the pilgrimage for members of the Ahmadiyya brotherhood, which is influential in the south-west of Nigeria. As for the founder of the 'Nigerian Taliban', Muhammad Ali, and Mohammed Yusuf's Izala mentor, Mahmud Ja'afar Adam, they developed their teachings after being trained in Saudi Arabia, while an early follower of Boko Haram, Bashir Mustafa, had studied in Medina before his killing in 2010.

However, the pilgrimage has also contributed to the expansion of Sufi brotherhoods, the great rivals of Wahhabi and Saudi forms of Salafism in Africa. It has legitimized the emergence of Tijaniyya jihadists such as El Hadj Muhammad al-Amin, a.k.a. 'The Soninke', in Mali or the founder of the Toucouleur Empire in Senegal, El Hadj Umar Tall, who had also studied Islam in Cairo for four years. ${ }^{43}$ As for Nigeria, the encounter in Mecca in 1937 between the Emir of Kano, Abdullahi Bayero, and the Senegalese Tijaniyya leader, Sheikh Ibrahim Niasse, was crucial. It is indeed the starting point of the expansion, in the most populous country in Africa, of a movement that had first started to spread from Senegal, following trade routes towards Ghana, Niger, Chad, and Cameroon. In the Kano region, specifically, talakawa masses were drawn to Tijaniyya because it was closer to the people and less elitist than the Qadiriyya brotherhood of the sarakuna nobility. In 1945, a visit of Sheikh Ibrahim Niasse then finally convinced the Emir of Kano to rally a movement that allowed him to overcome the tutelage of the Sultan of Sokoto, a member of the Qadiriyya.

The magnitude of the pilgrimage pushed the Wahhabis to compromise and welcome Muslims who did not follow their Hanbali rituals, including the Shiites. ${ }^{44}$ After taking control of Mecca in 1924, the Saudis had first banned some prayers, destroyed some ancient tombs and restricted the access of religious leaders of the three other orthodox Sunni Islamic schools of jurisprudence: the Hanafi, Maliki, and Shafi'i. But the regime did not have oil money and was quite poor. It needed the financial and political support of the Muslim world to recognize its sovereignty

42 Mervyn Hiskett (1980), "The "Community of Grace" and its opponents, the "Rejecters": A debate about theology and mysticism in Muslim West Africa with special reference to its Hausa expression', African Language Studies 17: 126.

43 See, for example, Humphrey Fisher (1970), 'The early life and pilgrimage of Al-Hajj Muhammad AlAmin the Soninke (d. 1887)', The Journal of African History 11(1): 51-69.

44 David Long (1979), The Hajj Today: A Survey of the Contemporary Makkah Pilgrimage, Albany, State University of New York Press, pp. 95 \& 108. 
and independence. As a result, it had to restrain the zeal of its sectarian supporters in the Ikhwan ('brothers') militia. During a world congress in Mecca in 1926, the authorities formally allowed believers from other countries to perform their own rituals. ${ }^{45}$ Since then, the increasing number of pilgrims has forced the monarchy to negotiate national quotas and tone down the masculine rigour of original Wahhabism, as women now make up half of the pilgrims who travel to Mecca each year. ${ }^{46}$ Under the pretext of modernizing the holy city, the Saudis also began to raze old buildings, including the mausoleums of the Prophet's family, not just the Sufi shrines which the Wahhabis despise. Giving in to easy oil money, they disfigured the site and built an American-style city. ${ }^{47}$

Historically, moreover, Mecca was mainly a sanctuary, not a hub for jihad training. For Africans, exile to the holy city may have been a form of silent protest, instead of resorting to violence. ${ }^{48}$ Indeed, Mecca was a place of refuge, or even of illegal immigration, because of its special and cosmopolitan status within the Saudi territory. Thus, it is there that Mohammed Yusuf went in search of an alibi and asylum when Nigerian security forces started looking for him after the uprising of the Taliban in Kanama in 2003. It is also there that, during his own pilgrimage in 2004, the Deputy Governor of Borno State, Adamu Shettima Yuguda Bilal, negotiated the return to Maiduguri of Boko Haram's founder. The Wahhabi influence of Mecca on Mohammed Yusuf is actually questionable. The founder of Boko Haram had already radicalized before the pilgrimage. Once back in Maiduguri, he then broke away from the Salafist Izala, who considered him a heretic.

The role played by Saudi Arabia in framing a global Salafi ideology deserves further discussion. Historically, Sahelian jihads in the $18^{\text {th }}$ and $19^{\text {th }}$ centuries were led by Africans and not by Arab preachers. ${ }^{49}$ Among them, only three had made the pilgrimage, and it was the colonizer who stressed their alleged Wahhabi or Mahdist connections. ${ }^{50}$ Usman dan Fodio, for example, never went to Mecca. Trained in Agadez in Niger, he also did not need the Qadiriyya to take up arms, even if the brotherhood's teachings may have legitimized his fight. His successors

45 Achille Sékaly (1926), 'Les deux congrès islamiques généraux', Revue du monde musulman 64: 22.

46 Robert Bianchi (2004), Guest of God, Pilgrimage and Politics in the Islamic World, Oxford, Oxford University Press, p. 358.

47 Ziauddin Sardar (2015), Histoire de La Mecque. De la naissance d'Abraham au XXIe siècle, Paris, Payot, p. 476.

48 Murray Last (1970), 'Aspects of administration and dissent in Hausaland, 1800-1968', Africa 40(4): 352.

49 Nehemia Levtzion (1987), 'The eighteenth-century: Background to the Islamic revolutions in West Africa'. In: Nehemia Levtzion \& John Voll, eds, Eighteenth-Century Renewal and Reform in Islam, Syracuse (NY), Syracuse University Press, pp. 21-38.

50 Roman Loimeier (2010), 'Africa south of the Sahara to the First World War'. In: Francis Robinson, ed., The New Cambridge History of Islam: Volume 5. The Islamic World in the Age of Western Dominance, Cambridge, Cambridge University Press, p. 273. 
also avoided going away, at a time when a journey to Mecca took several years and would have forced them to relinquish power, like the Christian kings during the Crusades. As Humphrey Fisher notes, the Fulani from Sokoto's ruling class were afraid of a possible rebellion of the Hausa masses, who identified less with their emirs, perhaps because Islam had been imported into the region by foreign preachers of Fulani, Kanembu, Kanuri, or Wangarawa (Mande) stock. ${ }^{51}$ Theologians also justified such bending of religious duty by arguing that taking part in jihad opened the gates of Paradise and exempted believers from their obligation to go to Mecca. Additionally, a local legend had it that the first pilgrimage of the Sultan of Sokoto would herald the end of the world and provoke a mass exodus of God's chosen people, the Fulani, towards the Gulf. Paradoxically, it was the British colonizer who, by consolidating the authority of the caliphate and developing transport, made it possible for the ruler to leave in order to perform his religious duties.

\section{Local networks of Islamic preaching}

Today, it is not exactly clear whether Mecca facilitated the mobilization of Boko Haram's followers. For example, out of 51 presumed members of the sect held in the prisons of Koutoukale and Kollo in Niger, only one had made the pilgrimage. ${ }^{52}$ In the long run, there should not be too many speculations about the effects of globalization and advances in telecommunications. In practice, Boko Haram's process of recruitment and indoctrination still relies heavily on personal contacts and individual affinities in a context of strong solidarity based on lineage, or even of omerta, in the face of abuses from government forces, who are perceived as occupation troops. ${ }^{53}$ Since the early 2000 s, the sect's expansion highlights the importance of local networks that make possible the dissemination and transmission of a radical Islam. In those networks can be found the usual places of indoctrination for jihad: markets, mosques, prisons, Quranic schools, camps for refugees or displaced persons. Videos of Mohammed Yusuf's sermons on DVD,

51 Humphrey Fisher (1977), 'The eastern Maghrib and the central Sudan'. In: John Fage \& Roland Oliver, eds, The Cambridge History of Africa, vol.3: From c. 1050 to c. 1600, Cambridge, Cambridge University Press, p. 326; Olayemi Akinwumi \& Raji Adesina (1990), 'The Wangarawa factor in the history of Nigerian Islam: The example of Kano and Borgu', Islamic Studies 29(4): 375-85.

52 Interviews conducted by the author early 2015.

53 Complicity at the local level thus explains why it was difficult for the army and the police to apprehend the rebels. Smugglers and Mbororo Fulani herders in the region, for example, are used to evading the police, even when it means not denouncing the bandits who rob them and give a part of their booty to village chiefs in order to buy the silence of the authorities. See Saïbou Issa (2010), Les 'coupeurs de route'. Histoire du banditisme rural et transfrontalier dans le bassin du Lac Tchad, Paris, Karthala, 273 p.; Saïbou Issa (2006), 'La prise d'otages aux confins du Cameroun, de la Centrafrique et du Tchad: une nouvelle modalité du banditisme transfrontalier', Polis, Revue camerounaise de science politique 13(1-2): 119-46. 
audio cassettes, and MP3 files have contributed to the movement's reputation. With the information we have so far, however, it is difficult to assess the role they may have played in recruiting followers and fighters who joined the jihad for a variety of other reasons: personal vendettas, persecution by security forces, opportunism, etc.

Mosques are, in principle, preferred spaces for the teaching of Islam, especially for the Izala, more so than for Sufi brotherhoods. Mohammed Yusuf's determination to create his own religious centre (markaz) close to the railway station in Maiduguri highlights their importance, while his second-in-command, Abubakar Shekau, preached in his own mosque, called Daifatul Mansura. In the dictatorships of the Arab world, mosques became the main place of protest and dissent, as other mediums of opposition were progressively shut down (political parties, trade unions, universities, associations), somewhat as churches were in East European Communist countries. In the Lake Chad Basin, however, Islam is also preached outside the mosque with outdoor recitations (tajwid) or exegesis (tafsir) of the Quran. Before the military crackdown of 2009, Boko Haram's followers went to bus stations and markets in small communities such as Geidam. There, they managed to reach farmers who would come to town to sell their agricultural products outside the days of prayer on Fridays.

Observers emphasize the role of Koranic schools in indoctrinating itinerant students called talibé, or, in Nigeria, almajirai (sg. almajiri) in Hausa and fukarbe in Fulani (sg. pukaraajo). In Newsweek magazine in Lagos on 16 January 2012, famous Nobel laureate Wole Soyinka, a self-proclaimed atheist, compared for instance the almajirai to a 'horde' of unemployed people in the service of terrorism and criminal politicians. ${ }^{54}$ Indeed, many commentators liken the almajirai to street children and feel that they have been radicalized because they live in poverty and have nothing to lose. According to them, Quranic students make up the bulk of the sect's recruits. Of the 34 Boko Haram veterans interviewed in Maiduguri and Bama in 2014, for example, it turns out that the vast majority had gone to Quranic rather than public schools. ${ }^{55}$ However, other surveys yield different results. Among the 51 suspects believed to be sect members who were interviewed by the author in the prisons of Koutoukale and Kollo in Niger in early 2015, the number of those who had attended primary school was the same as those who had attended Quranic schools. It should also be noted that 15 of them had never been to school, either public or Quranic. ${ }^{56}$

54 http://europe.newsweek.com/wole-soyinka-nigerias-anti-christian-terror-sect-boko-haram64153 ? $\mathrm{rm}=\mathrm{eu}$

55 Sani Umar \& David Ehrhardt (2015), Pathways to Radicalization: Life Histories of JAS Members, Abuja, NSRP, p. 9.

56 For similar results, see also Lisa Inks, Rebecca Wolfe \& Iveta Ouvry, eds, (2016), Motivations and Empty Promises: Voices of Former Boko Haram Combatants and Nigerian Youth, Portland (Orgeon), Mercy Corps, p. 24. 
Historically, the first members of the 'Nigerian Taliban' in Kanama were from the University of Maiduguri, such as Bili Tashe, Grema Terrab, and Maikanti Ndimi, the son of a rich merchant from Borno State who had made a fortune in oil and in whose mosque the founder of Boko Haram, Mohammed Yusuf, delivered his first sermons. ${ }^{57}$ Kabiru Sokoto and Aminu Sadik Ogbwuche, the brains behind the attacks on St. Theresa Church in Madalla in 2011 and on the Nyanya bus station in Abuja in 2014, also went to high school, and the latter even took courses at the university level. Their level of education did not prevent them from turning to violence, just like Sheikh Ibrahim el-Zakzaky's 'Shiite' extremists who were part of the MSS (Muslim Students Society) and who recruited heavily on campus at Ahmadu Bello University in Zaria. ${ }^{58}$ Also, available studies on other countries show that there is no clear correlation between levels of education and involvements in terrorism. ${ }^{59}$ A great example of this is Marc Sageman's work based on the profiles of 172 imprisoned al-Qaeda members, not to mention Osama bin Laden and his successor, Ayman al-Zawahiri, who was trained as an engineer and a physician. ${ }^{60}$

In Nigeria, the role of the almajirai remains controversial, both in the media and in academia. On the one hand, some believe that education and knowledge promote negotiation skills because they make it possible to approach the ruling class and identify the right people with whom to start a dialogue. In contrast, ignorance leads people to overthrow established powers for lack of being able to talk to them. For others, however, young people who have gone through the secular school system are more likely to be attracted to jihad than those who attended a Quranic school and who have at their disposal arguments to condemn the use of violence. Thus, one of the Quranic students, originally from Geidam, who was interviewed by the author in early 2015 in the Koutoukalé prison explained that their marabout would threaten to whip them if they were caught attending a Boko Haram sermon. The sect did not hide its hostility towards the traditional teaching practised by mallams,

57 It is actually thanks to their financial resources that, during a meeting in Damagum in Yobe, they convinced Mohammed Yusuf to join their extremist positions against Western education. See Abdul Kareem Ogori (18 December 2010), 'Return of the Boko Haram', Politico, pp. 11-16.

58 Officially, Ibrahim el-Zakzaky denies being Shiite in order to attract Sunni Muslims. Funded by Teheran, he was nonetheless presented as the Nigeria's Shiite leader on the English-speaking channel of the Iranian television in an interview broadcast on 25 March 2013 (video in possession of the author). As for the number two of his movement, Mallam Muhammad Turi, he was an accountant who received his diploma from the University of Maiduguri and who was reportedly killed by the Nigerian Army during an attack on Ibrahim el-Zakzaky's house in Zaria in December 2015.

59 Philip Keefer \& Norman Loayza, eds, (2008), Terrorism, Economic Development, and Political Openness, Cambridge, Cambridge University Press, pp. 83-115;Kamaldeep Bhui, Nasir Warfa \& Edgar Jones (2014), 'Is violent radicalisation associated with poverty, migration, poor self-reported health and common mental disorders?', PLOS ONE 9(3). doi:10.1371/journal.pone.0090718. For the cases of Jordan, Morocco, Pakistan, Turkey, Lebanon, and Palestine, see Alan Krueger (2008), What Makes a Terrorist: Economics and the Roots of Terrorism, Princeton, Princeton University Press, pp. 24-37.

60 Marc Sageman (2004), Understanding Terror Networks, Philadelphia, University of Pennsylvania Press. 
who therefore had to hide their writing tablets (allo) to escape the wrath of insurgents. Attached to the principle of the oneness of God (tawhid) and hostile to the intercession of the saints in Sufi cults, Salafists indeed consider Quranic school marabouts to be charlatans, and they criticize the secret prayers of their medical prescriptions, written on small pieces of paper and contained in gris-gris (kundi). In any case, the theory about the religious indoctrination of almajirai would apply only to Boko Haram's first phase of proselytization $\left(d a^{\prime} w a\right)$, before the military crackdown in 2009, when the group had to go into hiding and began to forcibly recruit young people or attract opportunist 'mercenaries' who came to fight alongside jihadists to get their share of the spoils of war.

In this regard, security studies specialists have a tendency to convey contradictory messages. On the one hand, they consider that Quranic schools lead to terrorism by indoctrinating future jihadists. On the other, they feel that these schools have lost their role as teachers of the rules of Islam, the foundation of social order. With the competition generated by the development of public schools during the oil boom in the 1970s, they produced young illiterates who were marginalized and unable to find a place in the labour market, which made them ideal recruits for armed groups. In one case, Quranic schools are thus criticized for what they teach; in the other, they are criticized because they no longer teach! Such a paradox also brings to mind the ambivalence of Boko Haram's rejection of a public education system which, affected by the economic crisis of the 1980s and 1990 s, had virtually ceased to function in many parts of northern Nigeria.

We should also take into account the ambivalent character of Quranic schools, which can be both a hotbed of radicalization or, conversely, a bulwark against the sectarian abuses of intolerant Islamic fundamentalists. In reality, different kinds of institutions teach the Quran under the supervision of teachers (mallamai in Hausa). For Mervyn Hiskett, tsangaya or makarantun allo Quranic schools are but simple kindergartens where children learn only to memorize and recite surahs. ${ }^{61}$ Murray Last points out that these institutions gained momentum mostly during the colonial period, when the pacification of the country and the abolition of slavery allowed farmers to let itinerant marabouts take their children away, as they could not feed them properly and their agricultural work was not needed during the dry season. ${ }^{62}$ A French administrator of the Mainé-Soroa border region said about them in 1934 that there was 'nothing special to report'. ${ }^{63}$ In fact, Quranic schools are similar to

61 Mervyn Hiskett (1975), 'Islamic education in the traditional and state systems in northern Nigeria'. In: Godfrey Brown \& Mervyn Hiskett, eds, Conflict and Harmony in Education in Tropical Africa, London, Allen and Unwin, p. 141.

62 Murray Last (1997), 'The "colonial caliphate" of northern Nigeria'. In: David Robinson \& Jean-Louis Triaud, eds, Le temps des marabouts: itinéraires et stratégies islamiques en Afrique occidentale française, v. 1880-1960, Paris, Karthala, p. 76.

63 Claude Boraud (August 9, 1934), Rapport de tournée de recensement du canton de Mainé Soroa, Mainé Soroa, p. 15. 
the kuttab (sg. katatib) of the Arab world and are different from the 'Institutes for Islamic Higher Education' (makarantun ilmi in Hausa). In Nigeria, they are open to students of all ages, including adults, and teach Arabic, theology, and law under the guidance of an alim (pl. ulama). ${ }^{64}$ They also differ from madrasahs, which were regulated by a 1934 colonial law and were initially created to train Quranic judges, before they adopted the national curriculum and started accepting women under the reformist pressure of the Izala in the 1970s. ${ }^{65}$

In the Nigerian system, madrasahs and Institutes for Islamic Higher Education are in fact part of the Muslim establishment. Unlike Saudi Arabia or Iran, however, they are not intended to train administration officials, except for the judges (qadi) of the colonial judicial system. Moreover, Nigerian madrasahs are less bureaucratic than they are in the Arab world, Indonesia, or Turkey, whose education systems and diplomas are more standardized. But the Izala philosophy, often dominant, advocates the infiltration of its followers into the state apparatus and not an open and armed confrontation with the secular power, a position that was also at the origin of the ideological rift between Mohammed Yusuf and the Izala. A priori, nothing leads us to assume that Islamic and modern types of education are necessarily incompatible and mutually exclusive; in Borno, Quranic private religious schools actually develop following the example of Christian schools that survived the nationalization of missions at the end of the Biafra War in 1970. In any case, there are no records of Boko Haram officers attending Nigerian madrasahs. As for Mohammed Yusuf, he was expelled by the Izala from the Indimi mosque in Maiduguri precisely because he did not have the theological training and qualifications required by the Saudi curriculum to teach the Quran; unlike Usman dan Fodio, his charisma and oratory skills were more important than his knowledge of Islam in spreading his beliefs.

It also turns out that the sect did not develop through madrasahs but by establishing dissident mosques and preaching outdoors, in markets, before the extrajudicial execution of its founder during the military crackdown in July 2009. Since then, the group has continued to rally to its cause those who suffer the abuses of security forces. Prisons and camps for displaced people then became recruiting grounds. ${ }^{66}$ In Africa, little is known about the way in which overcrowded prisons may indoctrinate, radicalize, and prepare young delinquents for jihad, unlike Western prisons in which detainees are separated carefully. In Nigeria and to a lesser extent in Niger - namely, in Diffa in July 2015 - it is a fact, however, that

64 Unlike its Arab and Iranian meaning, the ulema in Nigeria is a cleric and a scholar who has precedence over the ustaz, a preacher who is more of a counsellor or a schoolmaster, the mallam. Ulema is a function; ustaz is a title.

65 Muhammad Umar (2004), "Mass Islamic education and emergence of female "ulama" in northern Nigeria: Background, trends, and consequences'. In: Scott Reese, ed., The Transmission of Learning in Islamic Africa, Leiden, Brill, pp. 99-120.

66 Some even offer theories about hypnosis practices in training camps in rural areas. 
Boko Haram often attacked prisons, police stations, and barracks in order to release believers and, at the same time, gain new recruits. When he was arrested in November 2008 along with 63 disciples after trying to take over an Izala mosque in Monguno, Abubakar Shekau, for example, preached in the central prison of Maiduguri, which he then attacked in July 2009 to release his former fellow inmates. ${ }^{67}$

As the situation worsened, the fighting also caused people to move within Borno State or to neighbouring countries. Authorities thus feared the infiltration of Boko Haram amongst refugees and displaced persons. Indeed, Islam gives a particular value to victims of an exodus, in reference to the journey (hijra) of Prophet Mohammed and his companions, driven out of Mecca to Medina in 622. In the eyes of the fundamentalists, in particular, fleeing is just as legitimate as the holy war (jihad) and hiding (taqiyya) to fight against the invader and the oppressor. A Muslim who refuses to leave the lands of the heathen can even be considered an infidel. Usman dan Fodio's fighters, for example, treated such persons as criminals and seized their property, but not their women and children, unlike the unbelievers. ${ }^{68}$

However, Islamists do not always approve of the mobility of pastoralists. Paradoxically, the Fulani of the jihad in Sokoto could be seen as bad Muslims because they were often on the move, prayed outside the mosques, performed their ablutions with sand for lack of water, and shunned their religious obligations to take care of their herds. Himself a man of the city, the Prophet did not fail to denounce the immorality of Arabian Bedouins. It was Ibn Khaldun, instead, who praised the loyalty ('asabiyya) of nomads and farmers, as opposed to the corruption of merchants and urban dwellers. ${ }^{69}$ For the famous Arab historian of the $14^{\text {th }}$ century, urban populations were weakened by their 'governmental and educational laws', with armies made up of mercenaries and sedentary officials. On the contrary, rural nomads were braver because they fought for the survival of their community; besides, they were more willing to obey religious laws founded on divine rather than human injunctions. ${ }^{70}$ That is actually what happened when, from the $18^{\text {th }}$ century, Fulani pastoralists resumed the efforts to Islamize the Sahel

67 Interview with Professor Mohammed Kyari in Yola, 27 October 2015.

68 Herbert Richmond Palmer (Jul. 1914), 'An early Fulani conception of Islam', Journal of the Royal African Society 13(52): 407-14. Herbert Richmond Palmer (Oct. 1914), 'An early Fulani conception of Islam (Continued)', Journal of the Royal African Society 13(53): 53-59. Herbert Richmond Palmer (Jan. 1915), 'An early Fulani conception of Islam (Continued)', Journal of the Royal African Society 14(54): 185-92.

69 Joseph Schacht (1977), 'Law and justice'. In: Peter Malcolm Holt, Ann Lambton \& Bernard Lewis, eds, The Cambridge History of Islam, Vol. 2: Islamic Society and Civilization, Cambridge, Cambridge University Press, p. 541.

70 Ibn Khaldun, Abd al-Rahman ibn Muhammad (2002), Le livre des Exemples, Paris, Gallimard, p. 379. 
beyond cities such as Timbuktu, where clerics were more eager to defend the interests of traders than to reform and moralize the state. ${ }^{71}$

At the local level, refugees and migrants could therefore be both the recipients and the vehicles of proselytism, like the Wangarawa people of Mali who came to settle in Kano from the $14^{\text {th }}$ century, or the Umayyad exiles who started the Islamization of the Kanem-Bornu Empire in the $11^{\text {th }}$ century. ${ }^{72}$ In such a context, Boko Haram preachers targeted displaced people and farmers alike, which was done either in reference to the Quran, or in memory of the Sokoto jihad, or, pragmatically, to control the old contraband routes of the caravan trade. In refugee camps in Niger, Chad, and Cameroon, idle youths were also preys of choice for jihadists in search of recruits. Moreover, exile may have facilitated conversion efforts, something that had already been observed in Nigeria during the evacuation of some 45,000 Gungawa from the Yauri Emirate to allow for the construction of the Kainji dam in $1970 .^{73}$

\section{Boko Haram, a special case?}

All things considered, it would seem that the modes of dissemination of Boko Haram's ideology do not fundamentally differ from other jihadist insurgencies in the region, which also recruited fighters outside of mosques and among refugees or captives. Current changes are more the result of military and technological considerations. Historically, Usman dan Fodio's teachings had been passed on in writing, or orally (tariqa) in the case of Sufi brotherhoods. Meanwhile, leaders of the Tijani revival of the 1950s, called al-fayda ('the flood') or, sometimes, tajdid ('renewal' in Arabic), innovated by preaching on the radio. ${ }^{74}$ At the time, they had also to overcome the reluctance of the ulema, who did not want to mix the reading of the Quran with profane noises and to let listeners hear the Holy Book

71 Nehemia Levtzion (1987), 'The eighteenth-century: Background to the Islamic revolutions in West Africa'. In: Nehemia Levtzion \& John Voll, eds, Eighteenth-Century Renewal and Reform in Islam, Syracuse (NY), Syracuse University Press, pp. 21-38.

72 Thomas Hodgkin (1975), Nigerian Perspectives: An Historical Anthology, Oxford, Oxford University Press, p. 24.

73 At the time, the resettlement programme had given preference to Muslims, who made up $20 \%$ of the population, giving them access to housing, jobs in the public sector, loans and water pumps, while the complaints of 'pagans' were consistently rejected by the courts. See Frank Salamone (1983), 'The clash between indigenous, Islamic, colonial and post-colonial law in Nigeria', Journal of Legal Pluralism and Unofficial Law 21: 44; Frank Salamone (1975), 'Becoming Hausa: Ethnic identity change and its implications for the study of ethnic pluralism and stratification', Africa: Journal of the International African Institute 45(4): 417.

74 Andrea Brigaglia (2009), 'Learning, gnosis and exegesis: Public tafsīr and Sufi revival in the city of Kano (northern Nigeria), 1950-1970', Die Welt des Islams 49: 334-66; Andrea Brigaglia (2007), 'The Radio Kaduna Tafsir (1978-1992) and the construction of public images of Muslim scholars in the Nigerian media', Journal for Islamic Studies 27: 173-210; Brian Larkin (2008), Signal and Noise: Media, Infrastructures, and Urban Culture in Nigeria, Durham (NC), Duke University Press, p. 8. 
inadvertently while engaged in impure acts. Unlike more scriptural fundamentalist movements, this did not stop many Sufi sheikhs from favouring oral contests to challenge the religious content of cheap Salafi books sold at the market. ${ }^{75}$

As for Mohammed Yusuf, he used the Izala's methods to participate in theological debates on television in Borno State and disseminate his sermons through DVDs, cassettes, or MP3 files. ${ }^{76}$ The production of his videos was probably entrusted to one of the sect's early supporters, Mustapha Adam, who ran an audiovisual communication company called Dandagare. ${ }^{77}$ Boko Haram has also used more basic broadcasting techniques in rural areas - for example, in Niger by distributing leaflets written in Arabic and Hausa at the mosque in the village of Kelakam near Mainé-Soroa, as late as 2011. By the mid-2000s, Mohammed Yusuf's sermon handouts were also being circulated covertly. ${ }^{78}$ They eventually led to a self-published book, which was reprinted 15 days later on 6 May 2009, just two months before the uprising that led to the extrajudicial execution of Mohammed Yusuf. ${ }^{79}$

Boko Haram thus did not really introduce anything new in terms of dissemination technology. Neither its founder nor its critics stopped using books in a region where access to telephone networks and to the Internet had always been poor. ${ }^{80}$ In Jos in July 2015, Mohammed Yusuf's successors attempted to assassinate Muhammad Sani Yahya Jingir, the head of the Izala and a sheikh known for the tirades contained in his pamphlet entitled Boko Halal. In this respect, we should not focus too much on the viral videos showing Abubakar Shekau chewing a toothpick ${ }^{81}$ while claiming responsibility for the kidnapping of

75 Roman Loimeier (2003), 'Patterns and peculiarities of Islamic reform in Africa', Journal of Religion in Africa 33(3): 237-62.

76 Élodie Apard (2016), 'Les mots de Boko Haram. Décryptage de discours de Mohammed Yusuf et d'Abubakar Shekau', Afrique Contemporaine 255: 43-74.

77 Other very local production companies then appeared under the name of Darul-Islam, Khairul-Huda, and Sautus-Sunnah.

78 In March 2015, these sermons were also compiled, edited, and posted online via the group's new media channel, Al-Urwah al-Wuthqa. Accessed 11 September 2015:

https://azelin.files.wordpress.com/2015/03/jamc481 at-ahl-al-sunnah-li-1-da wah-wa-1-jihc481d-

22grouping-of-sermons-of-the-imc481m-abc5ab-yc5absuf-mue1b8a5ammad-bin-yc5absuf22.pdf

79 Mohammed Yusuf (2009), This Is Our Faith and Our Da'wa, Maiduguri, Al Farba, p. 166.

80 It is estimated that in 1900, just before British colonization, between 250,000 and 500,000 books circulated in today's northern Nigeria; they were essentially religious works, sometimes just simple copies, held by individuals or emirs, for lack of public libraries. See Murray Last (2008), 'The book in the Sokoto Caliphate'. In: Shamil Jeppie \& Souleymane Bachir Diagne, eds, The Meanings of Timbuktu, Dakar, CODESRIA/HSRC, p. 140. For general information about the spread of Islam in the Sahel through books written in Arabic, see Murray Last (2011), 'The book and the nature of knowledge in Muslim Northern Nigeria, 1457-2007’. In: Graziano Krätli \& Ghislaine Lydon, eds, The Trans-Saharan Book Trade: Manuscript Culture, Arabic Literacy, and Intellectual History in Muslim Africa, Leiden, Brill, pp. 178-211.

81 Made from acacia or arrack, the miswak in Arabic, also called makarkari in Hausa, is deemed to have the virtues of a toothpaste because it contains fluoride. To Salafists, it meets Prophet Mohammed's recommendation of brushing one's teeth daily upon waking up, at the time of the ablutions before prayer, when the mouth has a foul smell. 
the Chibok schoolgirls in 2014. In the context of rumours about his death or his exile in Mali in 2012, then Libya in 2015, Mohammed Yusuf's successor is actually just as present ... when he is absent.

However, his disappearances are not part of a communication strategy that would try to ridicule the authorities and resurrect an invisible imam whose death has been announced several times by Nigeria and Cameroon. Abubakar Shekau's absences are also different from the masking of Subcomandante Marcos of the Zapatista liberation army in Mexico. Neither do they seem to mirror the precautions of the Taliban in Afghanistan, who tried to hide the death of Mullah Omar, or the instructions of safety and anonymity of Daesh jihadists in Iraq, who have reduced the public appearances of their leaders to avoid drone attacks. In terms of strategy, the release of Abubakar Shekau's messages simply depends on opportunities to shoot videos which people in Borno are not able to watch anyway because of a lack of Internet access (only excerpts are broadcast on Hausa radio stations, which are very popular). In practice, the messages he started broadcasting in 2014 were first intended for the media; they were less used to relay the movement's ideology than to build the image of a terrorist group seeking international visibility. ${ }^{82}$

In the region, Boko Haram's communication strategy had to take on other forms that have remained inaccessible to Western media. It never reached the level of sophistication of the Izala in Nigeria or jihadist groups in Arabic countries. ${ }^{83}$ The sect actually remained a rather rudimentary and primitive organization that did not manage to acquire the propaganda tools of a political party or a guerrilla movement: radio station, underground press, website. ${ }^{84}$ Unlike Hamas or Hezbollah, for example, it did not create Islamic NGOs to raise funds, recruit young people, develop social projects, and be represented abroad. ${ }^{85}$ Technically, Mohammed Yusuf established a religious centre (markaz) in Maiduguri, formed a youth movement (Shabaab) in 2007, and granted loans to its poorest members. ${ }^{86}$ He tried to attract young people by paying for their wedding ceremonies and asking them for favours in return. His most accomplished form of assistance has been the creation of a fund that would later support the widows of combatants killed in the

82 Élodie Apard (2015), 'Boko Haram, le jihad en vidéo', Politique africaine 138: 135-62.

83 In an interview to the journal of the Islamic State Al-Naba in August 2016, a successor to Abubakar Shekau, Habib Muhammad Yusuf 'al-Barnawi', thus acknowledged that the original name of the group, the 'Sunni Congregation for the Propagation of the Prophet's Teachings and Jihad' (Jama'at Ahl alSunnah li'l Da'wa wa'l Jihad) was too complicated to pronounce and gave room for a nickname like Boko Haram ('Western education is a sacrilege').

84 Since 2013, the Izala have their own television channel, Sunnah $T V$, which complements Internet websites such as www.jibwisnigeria.org or https:/www.facebook.com/dandalinsunna/

85 See, in this volume, the insert 'Islamic NGOs in Niger and Nigeria'.

86 Usman Gaji Galtimari, ed., (September 2011), Final Report of the Presidential Committee on Security Challenges in the North-East Zone of Nigeria, Abuja, Federal Government of Nigeria, p. 16. 
battlefield, in contrast with the inability of the Nigerian state to pay pensions to the families of police officers or soldiers killed by insurgents.

Boko Haram was also able to capitalize on the anger of people who did not benefit from the country's wealth. The sect became popular by spreading accusations against the corruption of the elite, the sacrilege of apostates, and the abuses of the ruling class within a supposedly democratic system. Just like the Tijani or Usman dan Fodio's Fulani in the past, Boko Haram contested the Muslim establishment in order to make the knowledge of Islam accessible to the masses. From this point of view, it is reminiscent of the efforts of the Sokoto jihadists to teach the Quran to young people and women of the nobility, until their successors became part of the colonial order and tried to muzzle the criticism of Muslim scholars and opponents. ${ }^{87}$ In its own way, Mohammed Yusuf has contributed to the dissemination, the fragmentation, and the 'democratization' of Islam against the elites' monopoly on knowledge.

\section{Conclusion}

Compared with past insurgencies, Boko Haram's novelty must be put into perspective in this regard. ${ }^{88}$ Beyond military and technical aspects, the group will probably not leave much of a legacy from a strictly religious perspective. Like other jihadist groups in the $19^{\text {th }}$ century, its members mostly wanted to reform and spread the teachings of Islam through preaching ( $d a$ 'wa) and disseminating the writings of their emir. Despite the current focus of terrorism studies on the role of Internet and social networks, Abubakar Shekau's propaganda videos do not give a full account of the progression of the group's ideology. The quality of state institutions better explains why Boko Haram thrived in Nigeria and not in Niger, which is poorer but where social inequalities are less pronounced. ${ }^{89}$

Indeed, Nigeria is a federation that never had a single-party system. Niger, on the contrary, is a former military colony that developed on the basis of a police state whose local officials are still appointed by Niamey, despite recent

87 Jean Trevor (1975), 'Western education and Muslim Fulani/Hausa women in Sokoto, northern Nigeria'. In: Godfrey Brown \& Mervyn Hiskett, eds, Conflict and Harmony in Education in Tropical Africa, London, Allen and Unwin, p. 248.

88 Marc-Antoine Pérouse de Montclos (2015), 'Boko Haram et la mise en récit du terrorisme au "Sahelistan": une perspective historique', Afrique contemporaine 255: 21-41.

89 The Nigerian state's failure to act is impressive in this regard. As soon as 1994, the Borno State Islamic Preachers Board warned the government against the radical sermons of Jafar Adam Mahmuld at the Indimi mosque, where Mohammed Yusuf was to begin his career in Maiduguri. In Borno State, a 1977 decree and laws of 1981 and 2010 were actually supposed to regulate sermons and grant licenses to qualified people endorsed by emirates' councils. Violators risked small fines or imprisonment for up to six months, which was extended to ten years in 2010. In the same vein, a committee set up in 2000 to extend the scope of Sharia law planned to control and coordinate the activities of preachers and to register all Quranic schools in local governments. 
decentralization efforts. As a result, the country does not have the centrifugal tensions that Nigeria has, at least on its southern flank. Its national narrative is stronger and its institutions seem more robust at the local level. Niger has also inherited from the secular values of the French Republic, unlike British Nigeria, where the indirect rule favoured a stricter application of Sharia law. Within the sphere of influence of the Sokoto Caliphate, in particular, the British established a kind of government 'by proxy' that used the sultan's vassals to collect taxes and maintain law and order. Emirs were in charge of dealing with land and criminal cases in alkali courts (the Hausa version of Arab qadi), while customary law ruled family and business disputes. In contrast, the French followed a 'republican' model with a government 'by consent' and the support of opinion leaders such as the Sufi brotherhoods in Senegal.

Demographics also played a role. Compared with Niger, where $95 \%$ of the population is Muslim, Nigeria is much more populated and heterogeneous ethnically and religiously. Although both countries have comparable sizes, the challenges of colonial administrations were quite different in this regard. Few in numbers, the French ruled vast territories that were sparsely inhabited, while the British had to manage large masses. ${ }^{90}$ Besides, Christians and Muslims in Nigeria have a roughly similar weight, which may have exacerbated inter-religious competition and promoted the radicalization of fundamentalists. Finally, the country is more urban, a setting that is more conducive to the emergence of Salafi movements. ${ }^{91}$

In this context, the spread of Boko Haram is certainly not just the result of the success of its communication and globalization strategy. Contrary to Abdulbasit Kassim's statements, the group is not the first one in Nigeria to have tried to reconcile the revolutionary tradition of Sokoto with the demands of modernity in the context of a pan-Islamic jihad. ${ }^{92}$ At the crossroads of Saudi Wahhabism and the Qadiri teachings of his mentors from the Fulani aristocracy, the founder of the Izala, Sheikh Abubakar Gumi, had already begun, at Independence, to modernize Nigerian Islam on the basis of a spiritual effort. In any case, the comparison with Usman dan Fodio is not always relevant. Just like the Fulani who fought paganism

90 In the early $20^{\text {th }}$ century, there was roughly one settler for every 4,000 Africans in Niger, compared with one for 15,000 in Nigeria. See Camille Lefebvre (2015), Frontières de sable, frontières de papier: Histoire de territoires et de frontières, du jihad de Sokoto à la colonisation française du Niger, XIXeXXe siècles, Paris, Publications de la Sorbonne, p. 268.

91 Roman Loimeier (1997), Islamic Reform and Political Change in Northern Nigeria, Evanston, Northwestern University Press, 415 p.; Paul Lubeck (1986), Islam and Urban Labor in Northern Nigeria: The Making of a Muslim Working Class, Cambridge, Cambridge University Press, 362 p.; Paul M. Lubeck (1987), 'Islamic protest and oil-based capitalism: Agriculture, rural linkages and urban popular movements in northern Nigeria'. In: Michael J. Watts, ed., State, Oil, and Agriculture in Nigeria, Berkeley, University of California Press, pp. 268-90.

92 Abdulbasit Kassim (2015), 'Defining and understanding the religious philosophy of jihādī-Salafism and the ideology of Boko Haram', Politics, Religion \& Ideology, pp. 173-200. 
and decadent Hausa kingdoms in 1804, Mohammed Yusuf's followers rose against corrupt and repressive powers. Unlike Usman dan Fodio's fighters, however, they faced the forces of a modern postcolonial state formed on the basis of a model imported by the British. From this point of view, it should be mentioned that the 1804 Jihad was not bounded by internationally recognized borders. Paradoxically, it is the division of the world into sovereign states that gave Boko Haram its global dimension in the $21^{\text {st }}$ century.

\section{References}

BIANCHI, RoBert (2004), Guest of God, Pilgrimage and Politics in the Islamic World, Oxford: Oxford University Press.

Hassane, Moulaye, Marthe Doka \& Oumarou Makama Bawa (2006), Etude sur les Pratiques de l'islam au Niger, Niamey: Danida.

HisketT, MERVYN (1980), 'The "Community of Grace" and its opponents, the "Rejecters": A debate about theology and mysticism in Muslim West Africa with special reference to its Hausa expression', African Language Studies 17.

HisKetT, MERVYN (1975), 'Islamic education in the traditional and state systems in northern Nigeria'.In: Godfrey Brown \& Mervyn Hiskett, eds, Conflict and Harmony in Education in Tropical Africa, London: Allen and Unwin, p. 141.

IDRISSA, KIMBA (1994), 'Les révoltes paysannes et anticoloniales dans l'Ouest du Niger, 19051906', Paideuma 40.

IMAM, MuHAMmad SANI \& MUHAMmAD KYARI (2011), 'Yusufuyya and the Nigerian State: Historicizing the Dynamics of Boko Haram Phenomenon', Kaduna Journal of Liberal Arts $5(1)$.

InKs, Lisa, ReBecca Wolfe \& IVeta Ouvry, eds, (2016), Motivations and Empty Promises: Voices of Former Boko Haram Combatants and Nigerian Youth, Portland (Orgeon), Mercy Corps.

ISSA, SAÏBOU (2010), Les 'coupeurs de route'. Histoire du banditisme rural et transfrontalier dans le bassin du Lac Tchad, Paris: Karthala, 273 p.

KASSIM, ABDULBASIT (2015), 'Defining and understanding the religious philosophy of jihādīSalafism and the ideology of Boko Haram', Politics, Religion \& Ideology 16(2-3): 173-200.

KyARI, MOHAMmed (2006), Borno in the Rabih Years, 1893-1901: The Rise and Crash of a Predatory State, Maiduguri: University of Maiduguri.

LAST, MURRAY (1970), 'Aspects of administration and dissent in Hausaland, 1800-1968', Africa 40(4).

LEFEBVRE, CAMILlE (2015), Frontières de sable, frontières de papier: Histoire de territoires et de frontières, du jihad de Sokoto à la colonisation française du Niger, XIXe-XXe siècles, Paris: Publications de la Sorbonne.

LeVtZion, Nehemia (1987), 'The eighteenth-century: Background to the Islamic revolutions in West Africa'. In: Nehemia Levtzion \& John Voll, eds, Eighteenth-Century Renewal and Reform in Islam, Syracuse (NY): Syracuse University Press, pp. 21-38.

LOIMEIER, ROMAN (1997), Islamic Reform and Political Change in Northern Nigeria, Evanston: Northwestern University Press, 415 p.

LOVEJOY, PAUL \& JAN HOGENDORN (1990), 'Revolutionary Mahdism and resistance to colonial rule in the Sokoto Caliphate, 1905-6', Journal of African History 31(2): 217-44. 
Marthe, DaOuda Mamadou (2015), Dans les marches nord du Borno (Bornou). Les mutations politiques coloniales dans l'Est nigérien (1893-1960), Paris: L'Harmattan.

MASQUeliER, Adeline (2012), 'Public health or public threat? Polio eradication campaigns, Islamic revival, and the materialization of state power in Niger'. In: Hansjörg Dilger, Abdoulaye Kane \& Stacey Langwick, eds, Medicine, Mobility, and Power in Global Africa, Bloomington: Indiana University Press, pp. 213-40.

Murtada, Ahmad (2013), Boko Haram in Nigeria: Its Beginnings, Principles and Activities, Kano: Bayero University, Salafi Manhaj.

PÉrouse de Montclos, MARC-Antoine (2016), 'Boko Haram: A jihadist enigma', Small Wars \& Insurgencies 27(5): 878-95.

Perouse de Montclos, Marc-Antoine (2015), 'Boko Haram et la souveraineté du Nigeria: une histoire de frontières', Hérodote 159: 58-75.

Perouse de Montclos, MARC-Antoine (2015), 'Boko Haram et la mise en récit du terrorisme au "Sahelistan": une perspective historique', Afrique contemporaine 255: 21-41. 


\title{
Insert B
}

\section{Boko Haram's recruitment processes:Ideological and pragmatic considerations}

\author{
Élodie Apard
}

The different phases of Boko Haram's evolution ${ }^{1}$ correspond to distinct stages in its ideological and military development, ${ }^{2}$ but also to different motivating factors for joining as well as different recruitment techniques. The data collected by the researchers involved in the Trans-Islam project through the course of their fieldwork in Niger and Nigeria can shed light on these issues.

Firstly, Marc-Antoine Pérouse de Montclos was able to meet with suspected members of Boko Haram who were detained in the high-security prisons of Kollo and Koutoukalé in Niger. He interviewed men who had joined the movement, whether on a voluntary basis or not, and who shared with him background information as well as their reasons for joining Boko Haram. ${ }^{3}$ Secondly, Kyari Mohammed met with victims of the conflict in IDP camps located in north-east Borno and in the south-east of the Diffa Region; they spoke about the pressure that the group exerted on people in the areas it controlled. Finally, thanks to the analysis of sermons and video messages analused by Élodie Apard and Abdoulaye Sounaye, the various arguments used by the group's leaders and its detractors can be factored into our analysis of its attractiveness.

The scale of the insurgency and the movement's ability to mobilize combatants, either willingly or by force, have often been attributed to unemployment or poverty among the affected populations, or to the lack of education in northern Nigeria. Although street children - especially students of Quranic schools who are forced to panhandle - do seem like ideal recruits, this would be an extremely limited reading of the situation. ${ }^{4}$ Financial and material elements are often cited when analysing the spread of the conflict throughout the region and the recruitment of combatants

1 This insert deals with the history of 'Jama'at Ahl al-Sunnah li'l Da'wa wa'l Jihad', popularly known as Boko Haram, the group founded by Muhammed Yusuf and later led by Abubakar Shekau. It doesn't cover the current period characterized by the split into two factions and the emergence of ISWAP, affiliated to the Islamic State. The first 10 years of the movement have been described and analysed by Mohammed Kyari, 'The message and methods of Boko Haram'. In: M.-A. Pérouse de Montclos, ed., Boko Haram. Islamism, Politics, Security and the State in Nigeria, Leiden, IFRA-Nigeria/African Studies Centre, 2014, pp. 9-32.

2 See Élodie Apard, 'Boko Haram: Le Jihad en Vidéo', Politique Africaine 138: 135-62.

3 Between February and May of 2015, Marc-Antoine Pérouse de Montclos met with 51 detainees arrested during the fight against terrorism. The interviews took place at the Kollo and Koutoukale prisons, located a few dozen kilometers from Niamey, with no jailer present and with the assistance of a HausaKanuri-French translator. Some of these interviews were recorded.

4 See Hannah Hoechner, 'Traditional Quranic students (Almajirai) in Nigeria: Fair game for unfair accusations?' In: M.-A. Pérouse de Montclos, ed., Boko Haram, Islamism, Politics, Security and the State in Nigeria, Leiden, IFRA-Nigeria / African Studies Centre, 2014, pp. 63-84. 
outside of Nigeria. While economic motivations do play a significant role in Boko Haram's ability to mobilize, these factors alone do not explain everything.

Taking into account the different phases of the movement's evolution makes it possible to discern differences in its construction, restructuring, and strengthening processes. Indeed, since its inception, the movement's nature, methods, and objectives have continued to evolve. This type of analysis highlights the complex circumstances of a person's recruitment as well as the diverse nature of the combatants' profiles.

\section{'Peace of mind'}

One of the prisoners interviewed in Niger, who had joined the movement in 2006, said he had done so for 'peace of mind'. ${ }^{5}$ While his choice of words may seem surprising today, it must be contextualized to be understood. In the early 2000s, implementation of Sharia law was extended to 12 states in northern Nigeria. ${ }^{6}$ This decision led to violence in some northern states, including in Kaduna State, which then escalated into Muslim-Christian riots. These were part of a long series of political clashes interpreted as inter-religious violence in Nigeria. For this prisoner, a multi-faith society is bound to be the site of conflict and violence, which could be avoided by separating religious communities. From his point of view, the solution lay in the creation of a self-governed, independent territorial entity made up of the Nigérien and Nigerian states: an exclusively Muslim space in which the lives of individuals would be governed by the law of God. This extended implementation of Sharia had been largely supported by the population of northern Nigeria, as people hoped for greater social justice - and for a more effective fight against corruption in particular. However, Sharia implementation proved to be a double failure. Firstly, it did not replace the secular legal system entirely, which means that it did not solve the problem of the coexistence, within the same political space, of secular and Islamic laws. ${ }^{7}$ Secondly, Sharia clearly did not solve problems of inequality, injustice, and corruption. Mohammed Yusuf's political and religious project therefore attracted those who had been disappointed by this failed attempt to implement Sharia, as well as Muslims who believed that they would not be able to live and thrive in a state they considered to be unholy.

\section{Mobilization (2005-2009)}

In a second phase, Mohammed Yusuf, founder of the movement, began actively proselytizing, using religious discourse in order to convince and mobilize people. His regular and frequent sermons - in Borno State, especially in Maiduguri, but also beyond - earned him a solid popularity. While his critics often decried his limited knowledge of Islam, he was a very charismatic public speaker. His sermons were always filmed and then shared on DVDs or as MP3 and MP4 files, which significantly helped with the spread of his message. ${ }^{8}$

His sermons - usually delivered in Hausa, but also sometimes in Kanuri - were the main tool used in the dissemination of his ideology. In a region where Hausa was the predominant language, his word spread very easily, reaching beyond the Nigerian border. By the end of the 2000s, his sermons were very popular both in northern Nigeria and in Niger. One of the detainees interviewed in Koutoukalé explained: 'I listened to his tapes. I listened to him a lot before I saw

5 Interview conducted by Marc-Antoine Pérouse de Montclos in February 2015 at the Koutoukalé highsecurity prison in Niger.

6 There were states, however, in which it was never enforced. See Albert Dekker \& Philip Ostien (2009), 'L'application du droit pénal islamique dans le Nord-Nigeria', Afrique contemporaine 231(3): 245-64.

7 Susan M. O’Brien (2007), 'La charia contestée: démocratie, débat et diversité musulmane dans les "États charia" du Nigeria', Politique africaine 106: 46-68.

8 See Élodie Apard (2015), 'Les mots de Boko Haram. Décryptages de discours de Mohammed Yusuf et d'Abubakar Shekau', Afrique Contemporaine 255: 43-73. 
him in person' - while another stated that it was 'very difficult to find someone in northern Nigeria who has never listened to his sermons'. ${ }^{9}$

Yusuf also wrote a book, a kind of theological essay that was largely inspired by other Salafist authors. It was, however, written in Arabic, which made it less accessible to the population, and was published only posthumously ${ }^{10}$, which limited its impact in the first phase of mobilization.

His sermons focused primarily on the injustice which Muslims suffered both at the local and the international level. He would often mention inter-community massacres in Nigeria (in Kaduna in 2000, Onitsha in 2006), torture in Abu Ghraib, but also the prisoners in Guantanamo Bay or the Israeli-Palestinian conflict, to illustrate his point ${ }^{11}$. His goal was to use the crowd's feeling of injustice to provoke anger and fuel a desire for revenge. Yusuf also developed a discourse that justified the use of violence against state officials, as he held the state responsible for the violence and injustices suffered by Muslims ${ }^{12}$. His vitriolic anti-state positions were widely popular among a segment of the population with no access to basic services, for whom the state was represented only by an extremely rich and corrupt elite or, in rural areas, by the police.

Yusuf therefore promoted a certain social justice and proposed a community project that would provide a protective structure for its members. The community that started growing around him was known as the Yusufiyya (Yusuf's congregation), and many faithful moved into his markaz. ${ }^{13}$ It started as a simple mosque connected to his house, which then grew into a teaching centre and a living space where about a hundred people stayed on a permanent basis. ${ }^{14}$ According to one of the detainees met in Niger, the movement represented 'the love of Islam and Muslims', and Yusuf's popularity at that time could be explained by the fact that 'he (was) telling the truth'. ${ }^{15}$

As his sermons intensified, tensions with the Borno State government as well as with the federal government increased. His followers, gathered in his markaz, began to physically oppose the police, who placed the neighbourhood under surveillance.

\section{9: The point of no return}

The crackdown that took place in Maiduguri in 2009 is a pivotal moment which is key to a proper understanding of the movement's evolution. A series of acts of violence between members of the Yusufiyya and security forces led to a massive military crackdown in the town of Maiduguri, which resulted in hundreds of extrajudicial killings, including that of Yusuf. Having been arrested and interrogated at the police station, he was about to be transferred when he was intercepted - by members of the Mobile Police, presumably - and killed on the street ${ }^{16}$. Images of his dead body were widely shared on the Internet. His comments about injustices and police brutality suddenly took on a new dimension, turning him into a martyr.

9 Interviews conducted by Marc-Antoine Pérouse de Montclos in February 2015 at the Koutoukalé highsecurity prison in Niger.

10 Mohammed, Yusuf, (2009), Hādhihi 'Aqīdatunā wa-Manhaj Da'watinā. Maiduguri: Al-Ghurabaa' Library. A translation of the full text was carried out as part of the Trans-Islam research project.

11 Notably in a sermon delivered in Maiduguri in 2006. See É. Apard, 'Les mots de Boko Haram', op. cit, pp. 46-49.

12 An extensive translation and analysis work on the texts and discourses emanating from the group has been carried out by Abdulbasit Kassim and Michael Nwankpa, today available in an edited volume: A.Kassim \& M. Nwankpa, eds, (2018), The Boko Haram Reader: from Nigerian preachers to the Islamic State. London: Hurst,384 pp.

13 An Islamic center used for sermons and religious teachings.

14 Interviews with Mohammed Kyari, native of Maiduguri and contemporary of Mohammed Yusuf.

15 Interview conducted by Marc-Antoine Pérouse de Montclos in February 2015 at the Koutoukalé highsecurity prison in Niger.

16 As shown by the footage of his dismanteled body, lying on the floor and surrounded by the crowd. 
While it was meant to crush the movement, the crackdown proved counterproductive and ended up reinforcing it instead. Members of the movement subsequently went into hiding and kept a low profile. For about a year, they recruited in secret, especially people who had been the victims of the bloody July 2009 crackdown. They had seen in it the kind of threats that the state, which was supposed to protect them, represented for them. More than ever before, Yusuf's supporters were then ready to fight the state.

\section{Militarization of the movement}

In 2010, Abubakar Shekau - chosen by Yusuf to be his right-hand man just before he died became the leader of the movement, which he named Jama' at Ahl al-Sunnah li'l Da'wa wa'l Jihad (Sunni Group for the Propagation of the Prophet's Teachings and Jihad). The movement then started getting constantly involved in armed confrontations with the state and its representatives, attacking Christian communities and assassinating its Muslim opponents. Resentment was still the main instrument used for recruitment, as well as a certain desire for revenge. In his filmed speeches, Shekau uses Yusuf's rhetoric and brings up injustice, the need for revolt, and the legitimization of violence. ${ }^{17}$

The group acquired weapons, particularly through targeted operations on barracks, police stations, and weapons depots. The number of attacks increased sharply, while targets changed and now included prisons. While these attacks were carried out in order to free incarcerated members of the group, they often resulted in massive releases. This proved an effective recruitment method; once released, ordinary prisoners were at risk of being arrested again if they returned home, so they joined the movement. ${ }^{18}$

While the group reorganized and militarized, there were also organized and progressive recruitment processes similar to those of other criminal organizations: children who would monitor individuals, report information, transport small arms from one place to another, then carry out targeted executions, etc. - a series of small, recompensed tasks, gradually increasing in importance, which allowed recruits to earn a little money, but also to climb up the group's hierarchy, gain some confidence, obtain a certain status and, ultimately, join the movement. ${ }^{19}$

During this phase of rise in power and militarization, the Nigerian federal state responded exclusively through military action. However, as it lacked resources, the government decided to rely on the population and, in 2013, created civilian militias that would join the fight against Boko Haram. The Civilian JTF (Joint Task Force), made up of under-trained and under-armed young people, nevertheless proved to be effective, especially in the city of Maiduguri, which they were able to secure. But this system had a perverse effect in rural areas, where it created division. On the one hand, villages that supported the Civilian JTF or gave them new members were burned, razed, and their inhabitants massacred by Boko Haram. On the other hand, villages that did not provide members to militias or refused their presence were accused of supporting Boko Haram and were also burned, razed, and their inhabitants massacred, but by the army or the Civilian JTF themselves. Caught in a bind, the people sometimes had no other option than to join the movement as an act of survival: they would leave the village and join Boko Haram in order not to be killed, or to save their families.

Another form of forced recruitment was the abduction of young people (girls and boys alike). This phenomenon, which received a great deal of attention with the kidnapping of the Chibok girls, actually began much earlier and then continued. Indeed, the group started making repeated use of this method in 2013. Gradually, by creating a climate of terror, the movement lost the popular support it had previously enjoyed and turned more and more to kidnappings as a method of forced recruitment.

É. Apard, 'Les mots de Boko Haram', op. cit.

8 Many videos of prison attacks have been posted online. They show prisoners fleeing with the assailants.

19 Interviews with Mohammed Kyari. 


\section{Regionalization of the conflict}

In this fifth phase, new recruitment methods were developed. Economic factors played a more important role, and material and financial aspects emerged, which included Chinese motorcycles as well as the salaries offered to combatants in areas where Boko Haram had expanded its activities: south-east Niger and northern Cameroon. ${ }^{20}$ It should be noted that motorcycles are not an anecdotal element, as they constitute the main means of travel in these regions, where roads are almost non-existent; they are also a means of transporting goods and are therefore used for trade.

While the conflict was spreading to the peripheral areas of neighbouring countries, local crime was also being assimilated by the movement. The situation allowed small bandits or road robbers to operate within a new framework, one that could boost their influence and would sometimes offer also logistical support. Through opportunistic recruitments, the movement considerably strengthened its presence and power in these regions. ${ }^{21}$

There were also non-criminal opportunistic recruitments. This was the case, in particular, for workers whose sector was in crisis and who were then able to find new professional opportunities in a devastated economic context. One of the prisoners interviewed was a mechanic who specialized in motorcycle repairs and who had lost his job when the Nigérien authorities banned the use of two-wheelers in the city of Diffa, owing to motorcycle attacks by Boko Haram. Approached by an intermediary, he was offered work with the group members to repair their equipment; he thus joined as a motorcycle mechanic. ${ }^{22}$

The governments of countries affected by the crisis unfortunately adopted coercive measures that played a role in worsening people's livelihoods, which sometimes helped the group's recruitment efforts. For example, when the Nigérien authorities banned the sale of fish and peppers - the two main economic activities in the Diffa Region - many households were deprived of their source of income. Similarly, the massive village evictions in the Lake Chad Basin plunged hundreds of villagers into a situation that was so dire that joining Boko Haram seemed to be one of the only ways to survive. ${ }^{23}$

Finally, other motivating factors should also be taken into account: the desire to avenge the death of a loved one, being able to marry, the possibility of settling a personal or family dispute with weapons.

While all these elements contribute to a considerably richer analysis, they also reveal that no generalization can be made, that these phenomena can be read in a variety of ways, and that no sociological elements shared by all combatants can be identified. ${ }^{24}$ Recruitment into Boko Haram - whether it is the result of ideological convictions, a response to state actions, a desire for revenge, a lack of option, or a threat - seems to be motivated by individual stories and life circumstances. ${ }^{25}$ This multiplicity of situations, as well as the variety of methods used by the group to attract or coerce, make most responses inaccurate. 'De-radicalization' programmes, based on the assumption that the group uses religious indoctrination to recruit, have proved to be extremely difficult to define and implement.

20 Christian Seignobos (2014), 'Boko Haram: innovations guerrières depuis les monts Mandara. Cosaquerie motorisée et islamisation forcée’, Afrique Contemporaine 252: 149-68.

${ }^{21}$ See Corentin Cohen (2015), 'Boko Haram, une impossible sociologie politique? Un groupe armé catalyseur de la violence armée régionale', Afrique Contemporaine 255: 75-92.

22 Interview conducted by Marc-Antoine Pérouse de Montclos in February 2015 at the Koutoukalé highsecurity prison in Niger.

23 Alternative Espaces Citoyens (April 2015), 'Etat d'Urgence dans la région de Diffa. Rapport de la mission d'observation de la situation humanitaire et des droits de l'homme', $16 \mathrm{p}$.

24 Corentin Cohen, 'Boko Haram, une impossible sociologie politique?' op.cit.

25 See the UNDP report (2017): 'United Nations Development Program', Journey to Extremism in Africa, $113 \mathrm{p}$. 


\title{
Boko Haram along the Nigeria-Niger borderlands: Influences, scope, and management
}

\author{
Kyari Mohammed
}

\section{Introduction}

The north-east of Nigeria has been devastated by Boko Haram violence since July 2009, leading to thousands of lives and limbs lost, economic desolation, and a humanitarian disaster. However, the south-east of Niger, adjoining Nigeria's Borno State, remained largely unscathed until early 2015. The peoples of Nigeria and Niger share common historical, sociological, geographical, economic, and linguistic features, but yet there are differences. Both Borno in Nigeria and Diffa in Niger are poverty stricken, politically marginal, largely ungoverned, and excluded from national power; however, these discontents have not been either channelled politically or exploited by Boko Haram. This is because Boko Haram has consistently denigrated and opposed the extant state system as un-Islamic and therefore a legitimate target for its attacks. There are differences in the influence and reach of Boko Haram in the two countries, with Nigeria being the epicentre and battleground, while Niger - as well as Nigeria's near neighbours Chad and Cameroon - was gradually sucked into the conflict. This study looks at Boko Haram activities and their management by the state authorities in both countries. How similar or dissimilar were the responses? And how have these responses worked for each country? These are some of the major concerns we intend to address in this chapter.

Our study is based on a fieldwork carried out over 12 months in the Nigerian state of Borno and its Nigérien counterpart, the adjoining prefecture of Diffa, both in the heartland of historical Borno. In both places a number of informants were interviewed, including government officials, security agents, religious leaders, politicians, civil society activists, refugees, and internally displaced persons. The 
interviews took place at different times due to changing levels of insecurity in the affected areas. Desk research was conducted to review extant work before embarking on fieldwork. Several informants spoke on condition of anonymity, for security reasons. Finally, the findings were analysed using a comparative study approach to the two regions.

Map 8 Geographical distribution of Kyari's fieldworks

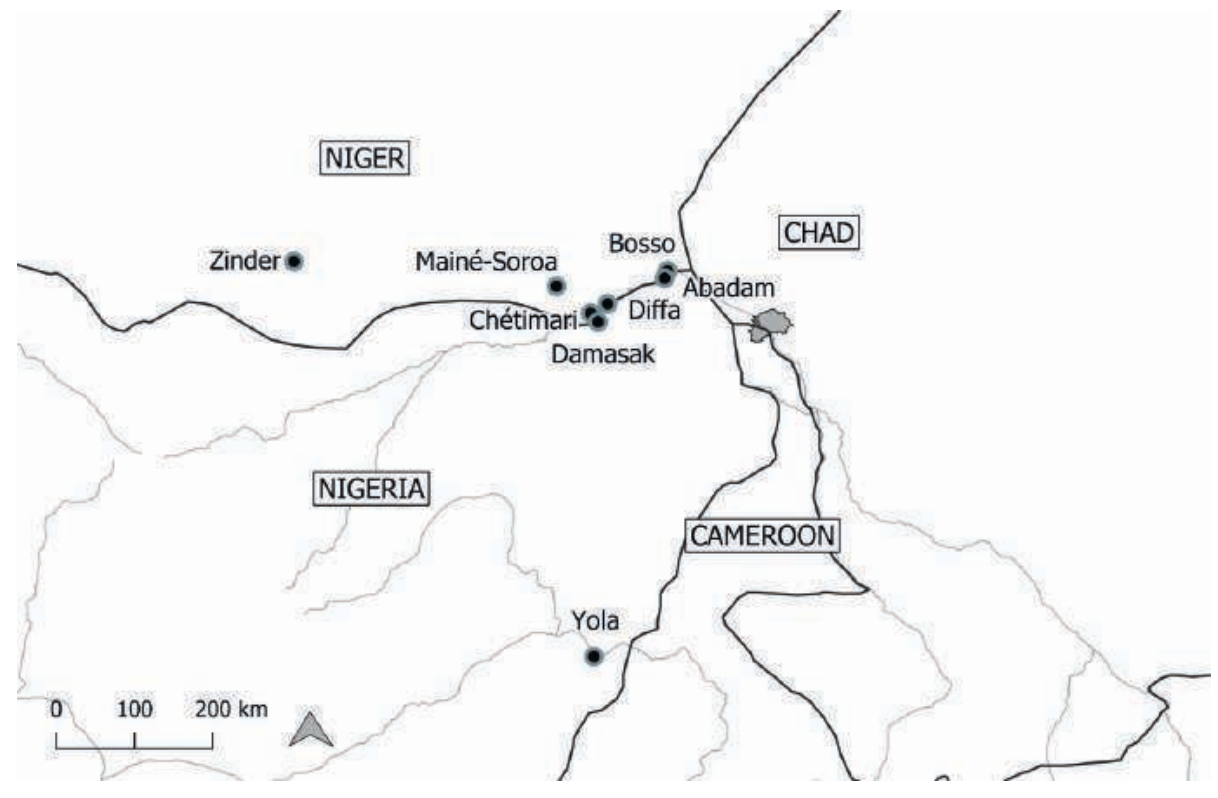

The main finding of the research is that the Boko Haram insurgency in the Diffa Region of Niger and in the far north region of Cameroon were a direct extension of the fighting in Borno State of Nigeria. However, Niger still remains relatively less affected than Cameroon to the south. All Boko Haram activities in Diffa were organized and directed from the Nigerian side even though some Nigériens became foot soldiers in the movement. The increasingly recurring raids on Diffa and Bosso were all organized and coordinated from across the border in Nigeria, with Nigérien and Nigerian insurgents taking part. The state's response to and management of the insurgency in the two countries are similar, including declaration of a state of emergency, forced displacements, excessive force, human rights abuses, and various draconian measures - for example, bans on the use of motorcycles and on the fish and pepper trade. These restrictions in both countries had deleterious consequences for the inhabitants and the displaced. 
We begin by outlining the similarities between the Borno and Diffa regions, indicating their strong historical links and economic ties. The evolution of Boko Haram and the movement's deliberate attempts to preach and recruit in border areas are highlighted, as well as the similarities in the management of the insurgency in the two countries.

\section{Background}

Nigeria and Niger share a very long and porous border, stretching from Say in the west to Baruwa in the east. Ethnic and religious groups along the border areas share the same history, sociology, ecology, environment, culture, and worldview. The Sokoto Caliphate and Kanem-Borno, the two major state systems astride what later became Nigeria and Niger, had influenced developments in this region before the colonial onslaught especially in the closing years of the $19^{\text {th }}$ century (Mohammed 1995). This intricate relationship along the border has impacted communities on both sides of the border, with implications for the politics, economy, society, and security of the two neighbouring states. What is today known as Jama'at Ahl al-Sunnah li'l Da'wa wa'l Jihad (People Committed to the Propagation of the Prophet's Teachings and Jihad) - popularly referred to as Boko Haram (roughly translated as 'Western education is forbidden') - evolved out of a tiny band of religious zealots influenced by takfiri ideology ${ }^{1}$, who took up arms against the Nigerian state in 2003/2004 at Kanamma on the Nigeria-Niger border. Kanamma, though on Nigerian soil, is only a few kilometres away from the border with the Diffa prefecture of Niger. The choice of Kanamma, a rural border community, is significant to the development of the military strategy, tactics, and recruitment of this group. After they were dislodged from Kanamma by the Nigerian military, the insurgents took refuge in the Mandara mountains on the Nigeria-Cameroon border, before they were eventually flushed out. Thus, the choice of rural and often difficult border communities was deliberate and strategic to this evolving movement (Mohammed 2014: 12). Boko Haram chose its operational bases deliberately with a keen eye for battles, cross-border proselytization, recruitment, supplies, expansion, and retreat when necessary. Kanamma was chosen for its remoteness and defensibility. Other border communities, such as Gwoza, Bama, Banki, Gamboru Ngala, and Damasak, were all chosen for similar reasons. Gwoza is mountainous and remote on the Cameroon border; Banki and Gamboru Ngala are remote and stand astride the NigeriaCameroon and Niger-Cameroon-Chad borders. The long stretch of ungoverned spaces along the course of the Yobe River, stretching from Damasak through

\footnotetext{
Takfir is the accusation of apostasy made by a Muslim against another Muslim.
} 
Abadam to Mallam Fatori on Lake Chad, has recently gained the attention of Boko Haram. This area, which had hitherto been relatively insulated from Boko Haram activities, has now become a hotbed of conflict and an operational base of the Islamic State West Africa Province (ISWAP). This is as a result of the splintering of Boko Haram as a faction under Abu Musab al-Barnawi, who challenged the leadership of Abubakar Shekau and has pledged allegiance to the Islamic State of Syria and Iraq since 2016.

Nigeria and Niger are culturally, historically, geographically, and economically inextricably interwoven, such that developments in one country reverberate in the other. The basic characteristic of border communities in the north of Nigeria and the south of Niger is the glaring absence of development and the presence of grinding poverty and mass misery. The question as to why border communities are neglected in national planning has been posed several times over the decades at important local and international fora (Asiwaju 1993; Asiwaju \& Barkindo 1993). The border separating the two countries is a colonial one, arising from the contest for supremacy between the British and French in the race for Lake Chad in the closing years of the $19^{\text {th }}$ century. This artificial border, which split the same ethnic and religious groups in the Sokoto Caliphate and Borno, created an anomalous situation by dividing the population into separate national states, while the communities carried on business as usual in their new nation-states. These boundaries were the result of numerous treaties, mostly signed first between 1890 and 1892 and then between 1904 and 1906, between the two colonial powers without any input from the colonized. In the Borno axis, the subject of this study, the new boundary split Borno between Britain and France along the northern and southern banks of the Komadugu Yobe, with all areas to the north passing into French hands (Inuwa 1993: 60).

\section{The Kanuri factor}

The Kanuri are the largest ethnic group in Borno, comprising the Borno and Yobe states of Nigeria as well as the Diffa Region of Niger; however, they are minorities in both countries. The influence of the Kanuri group is not its size or political significance but the historical grandeur and sense of achievement that went with membership of the Kanem-Borno empire, which covered a large part of the central Bilad al-Sudan. The Nigeria-Niger boundary separated a 'people with a common history, culture and tradition' (Tijani 1993: 76). Tijani asserts that this boundary 'not only divided up a people; it smashed up a cultural and political nexus which until hitherto was the most potent force that had cemented together the people of the entire sub region' (1993: 76). Thus, the Kanem-Borno empire, even though balkanized, 'continued to survive in the collective experience and psyche of its 
erstwhile citizens' (Tijani 1993: 77). This sense of brotherhood, the existence of trans-border families and unrestricted commercial exchange, as well as sociological and geographic factors, ensured the survival of Borno-ness in both countries. This was particularly pronounced in Niger, as the Kanuri are truly a minority, accounting for only 500,000 of the country's $12,500,000$ population (Idrissa 2014: 6).

The precolonial Kanem-Borno empire was based on a cultural foundation of Islamic principles, unlike its successors colonial and post-colonial states based on Euro-American secularism. Thus, the new state had a baggage of legitimation in the eyes of the inhabitants, particularly in border communities where the impact is greatest (Tijani 1993: 77). As a consequence, the Nigeria-Niger border is a meaningless construct in the day-to-day lives of the people, where it is mostly observed in the breach. In several communities, families are bisected across the borders or farmlands are in the other country. The historical town of Abadam is a good example: there is one each on either side of the border.

\section{The rise of Boko Haram to 2009}

Boko Haram began as a small, Nigeria-focused Salafi group on the Nigeria-Niger border at Kanamma in Yunusari LGA of Yobe State in December 2003. At this stage of their development they were known as the 'Nigerian Taliban' and were led by Muhammad Ali, a Nigerian resident of Saudi Arabia who was radicalized abroad. Muhammad Ali was the one who converted Mohammed Yusuf to this new radical version of Islam. Their choice of isolated and rural Kanamma on the Niger border is remarkable for its strategic importance. Kanamma was chosen for its remoteness from the bases of power, whether in Abuja, Damaturu, or Maiduguri, far from the prying eyes of security and away from urban distractions. Kanamma was also easily defensible, as it was forested and located between two bodies of water. Its closeness to Niger, just $3 \mathrm{~km}$ from the border, may also have been a factor in the choice of site.

The so-called Nigerian Taliban wreaked havoc on surrounding communities between December 2003 and January 2004, around Geidam, Yunusari, Yusufari, and Damaturu, and took refuge in the Mandara mountains at Gwoza. For most of 2004 they were in the Gwoza, Kala-Balge area on the Nigeria-Cameroon border. Therefore, the choice of remote, difficult, and inaccessible terrain along borders has been a deliberate policy of this group from its inception. They deliberately targeted border communities such as Kanamma, Damasak, Abadam, and Mallam Fatori on the Niger border, as well as Bama, Banki, Gamboru, Ngala, and KalaBalge on the Cameroon and Chad corridor. These areas turned out to be the centres of Boko Haram's post-2009 strength. Even though these border regions were used 
for recruitment, there was not much cross-border insurgent activity at this early stage. The remoteness from authority, the need to carry on activities undetected and unmolested, and the need for safe rear bases may have been the overriding concerns. However, trans-border recruitment did take place.

The survivors of Kanamma joined Mohammed Yusuf, who had returned from self-exile in Saudi Arabia in 2005, to form the nucleus of Boko Haram as we know it today. Muhammad Ali had died of wounds sustained at Yajiwa in January or February 2004. Thus, when the Boko Haram crisis erupted in July 2009, its adherents came from all cities across northern Nigeria and some came from Niger, Cameroon, and Chad. Kaka Bunu, the alleged leader of Boko Haram in Diffa, now in detention in Niamey, is believed to have fought in Maiduguri. He was arrested, interrogated, and released for lack of evidence by the Nigérien authorities. He was re-arrested following Boko Haram attacks on Bosso and Diffa in February 2015 (interview, BKH, Diffa, 6 November 2015).

The presence of Boko Haram on the Borno and Yobe frontier with Niger dates back to the Kanamma uprising of December 2003. As Boko Haram had not yet made Niger an objective nor declared it an enemy, the country remained relatively immune to the devastating war on the Nigerian side. This may be related to the fact that most of the fighting was still concentrated in central and southern Borno, far from the border with Niger. However, Boko Haram's presence in Niger was known to the security agencies of both countries. Muhammad Yusuf had repeatedly preached at Mustafa Jon's house in the border town of Damasak prior to 2009 (interview, Mustafa Shettima, Sayam, Niger, 6 November 2015). Mustafa Jon and Abubakar Kilakam ${ }^{2}$ were both deported to Niger by Nigerian authorities in late 2008 and in early 2009. The porosity of the border and kin relations across boundaries made deportations of religious scholars by secular authorities look like persecution. These people were deported, but they were not ostracized by either host or receiving communities, even if the latter did not agree with their doctrines and practices. Besides, at this time Boko Haram had not yet committed to violence nor antagonized the local populace.

It is generally believed that Boko Haram presence was minimal on the Niger side prior to 2009. In fact, Boko Haram adherents were limited even in Nigeria before their forced dislodgement from urban Maiduguri in June 2013. The dispersal to rural areas created new problems for management of the insurgency. The insurgents turned on local populations, a group they had not targeted before then, for their lack of support or for their complicity with the Nigerian state. The dispersal led to massive recruitment in the outlying areas such as Bama, Banki, Gwoza, Damboa, New Marte, Kirenowa, and Gamboru Ngala. Early military

Mustafa Jon, a trader based in Damasak, was a financial supporter of the group, while Abubakar Kilakam was an active member, who organized several attacks. Both of them are said to be from Niger. 
successes against the insurgents in 2014 - which led to the routing of Boko Haram camps at Kirenowa, New Marte, Nguro-Soye, and the edge of the Sambisa National Park to the south - had the effect of pushing the insurgents further north towards the shores of Lake Chad. Thus, settlements such as Baga, Abadam, Mallam Fatori, and Damasak further north and beyond military purview became new theatres of Boko Haram recruitment. The Buduma (also known as Yedina), another ethnic group found in all countries sharing Lake Chad and never completely Islamized, became a new reservoir of recruitment into Boko Haram. They joined in large numbers mostly out of ignorance but perhaps also on account of economic and political reasons. Membership of Boko Haram conferred power and certain privileges, such as access to women, authority over others, and power to extract resources, including booty. These are significant factors for a hitherto powerless group such as the Buduma.

On the Niger side, recruitment remained low-key, but the porosity of the border and the heavy admixture of peoples along the shores of Lake Chad made recruitment relatively easy when it commenced. There is no clearly discernible pattern in Boko Haram membership in Niger as there is in Nigeria. While there are estimates that the majority of Boko Haram in Nigeria, at least at leadership level, are of Kanuri extraction, the situation in Niger is slightly different, with a high proportion of the Buduma joining much later. However, the leadership seemed to be Kanuri even in Niger. Kaka Bunu, believed to be the amir in Diffa, is a local trader and sachet water producer, who was said to have taken part in the Maiduguri uprising in 2009. Alhaji Shettima Zainammi, a Kanuri native of Febulwa in Bosso, was believed to have led the Friday prayers when Boko Haram took over Mallam Fatori in November 2014. He was so influential as to be able to rescue his daughter from Boko Haram captivity. Ali Gana Nguldi, a Buduma language newscaster working for Radio Niger, is also in Nigérien detention for money laundering for, and membership of, Boko Haram. He is, as his name implies, Buduma. Aminu Dan Mallam, a local pick-up driver and transporter who had unrestricted access to Boko Haram-controlled territory across the border in Nigeria may be Hausa. Again, as in Nigeria, the leadership is predominantly Kanuri but the followership is mixed with a high preponderance of local inhabitants. As one moves progressively from west to east towards the lake, the ethnic composition of Boko Haram members changes from Manga to Mobbar to Buduma and Fulani, all of them speaking the Kanuri language.

Our interviewees in Maine Soroa and Diffa mention Tam to the north of Geidam, Ba'ara, Diffa Kura, Bulonguri, Assaga, and Kanguri as settlements where Boko Haram has engaged in substantial recruitment on the Niger side. Tam was notorious for its unorthodox practices and anti-Western education preachers akin to Boko Haram as early as 2008. Their activities were reported to Nigérien 
authorities, but freedom of religion was cited as a reason for no action being taken. Kilakam in Goudoumaria was another centre of Boko Haram activity (interview, KGK, Maine Soroa, 4 November 2015). Most of these recruits were fighting on the Nigerian side between Damasak and Mallam Fatori (interview, BKH, Diffa, 6 November 2015; KGK, Maine Soroa, 4 November 2015). The Jetko, a tiny ethnic group, for some inexplicable reason did not join Boko Haram. Typical of Boko Haram, the Diffa attack on 6 and 7 February 2015 was led by Adam, a Diffa native, who had not only joined the insurgents in Damasak but had risen to some standing within the movement. He was said to have evacuated his mother out of Diffa shortly before the attack. The Boko Haram takeover of Damasak in November 2014 made it a safe haven as well as an operational base for cross-border attacks into Niger, as shown by the attack on Diffa.

\section{Niger's response to and management of Boko Haram}

Nigeria's neighbours Niger, Chad, and Cameroon perceived and treated Boko Haram as a Nigerian problem. They were content to keep the insurgency at arm's length as long it remained within the boundaries of Nigeria. However, their dependence on Nigerian markets for the supply of food and commodities brought to the fore the futility of their neutrality. By 2014 Boko Haram had transformed from a local Nigerian problem to a regional menace, threatening the peace of all neighbouring countries. There were sporadic attacks across the border into Niger from Abadam LGA to the south of Bosso in the second half of 2014, but the coordinated attacks on Bosso and Diffa on 5 and 6 February 2015 were the real wake-up call. Not unexpectedly, Niger reacted with a declaration of a state of emergency on 10 February 2015. Nigeria had early on declared an emergency in several LGAs and states in 2011 and 2013. The emergency laws merely empowered the military to curtail the rights of citizens, leading to serial human rights abuses in both countries.

It is as yet unclear why Boko Haram attacked Bosso and Diffa. The attack on Bosso may have been to replenish their supply of arms and ammunition from the Nigérien military camped on the outskirts of the village; this is a strategy successfully used for procuring arms by the insurgents in Nigeria. Or it may have been to engage the Bosso cantonment and deter them from offering assistance to Diffa, which was attacked simultaneously. Or it may have been for both reasons. Diffa was attacked ostensibly to free some high-ranking Boko Haram captives held in the prison facility located in the township. The attackers successfully broke into the facility and killed the head of the prison, but they were unable to secure the release of their comrades. The attack on Diffa and the quick response with a state of emergency woke up the Nigérien government to the realization that Boko 
Haram had declared war on the state. At the time of writing, fighting is ongoing on both sides of the border around the banks of the Komadugu Yobe and the shores of Lake Chad, involving the Multinational Joint Task Force (MNJTF). The MNJTF comprises troops from Nigeria, Niger, Chad, Cameroon, and Benin Republic, under the auspices of the Lake Chad Basin Commission. Initially effective in halting Boko Haram on several fronts, the MNJTF was then beset by several problems, including funding constraints, national rivalries, and difficulties in coordination. These have affected its effectiveness in ending the conflict. In addition, Boko Haram's attacks on south-eastern Niger, the extreme north of Cameroon, and N'Djaména (capital of Chad) have forced these countries to concentrate on their homeland security, to the detriment of the MNJTF.

Niger, very much like Nigeria, securitized the Boko Haram insurgency. Nigeria's response to the Boko Haram insurgency is fairly well known, but a brief recapitulation is not out of place (see Mohammed 2014). Since July 2009 the Nigerian state has fought the insurgents through the use of military force, and the declaration of a state of emergency at least twice, in 2012 and 2013. These measures led to documented human rights abuses, including extrajudicial killings, detention without trial, dragnet arrests, bulldozing and burning down of houses, arrests of wives and children of suspected Boko Haram members, etc. (see Amnesty International 2011, 2012, 2013, 2014; BELT 2012; Human Rights Watch 2012 , 2013). The military operation against the insurgents has led to several successes as well as reverses. The successes led to the killing or capture of several leading commanders, overrunning of Boko Haram bases, and pushing the group out of urban areas of Maiduguri, Potiskum, Bama, etc. However, there were reverses when Nigerian military had to hastily retreat and cross the border into neighbouring countries, leading to desertion, demoralization, and courtmarshalling of officers as well as of men. The Nigerian military became the butt of uncharitable comments by Nigérien military commanders and politicians insisting that their soldiers would not run away from battle, unlike the Nigerians (interview, DMM, Diffa, 3 November 2015). These comments had the effect of putting enormous pressure on the Nigérien military when it began to fight. So how did Niger manage the insurgency?

The Nigérien authorities also securitized the insurgency and reacted in exactly the same way as their Nigerian counterparts. First they declared a state of emergency in the affected prefecture of Diffa, replacing the civilian governor with a military general, Abdou Kazah, in February 2015. The state of emergency came, not unexpectedly, with various draconian measures, including curtailing rights of movement, curtailing freedom of speech (hindering particularly the access of journalists to sites of conflict), banning the use of motorcycles as a means of transport, imposing curfew at night, banning the sale of petroleum products in 
plastic containers, banning the use of Nigerian-registered vehicles for public transportation, etc. Human rights abuses were widely carried out by the military and reported by Alternative Espaces Citoyen, leading to the arrest and detention of Moussa Tchangari, one of its leaders, for supposedly obstructing the fight against insurgency (Alternative, 2015; interview, Tchangari, Diffa, 3 November 2015).

The most serious consequence of the state of emergency was the ban on the production and sale of fish and pepper, as well as on fishing and farming on the banks and courses of the Komadugu Yobe and Lake Chad in Diffa. This was followed by forced relocation of all inhabitants of the shores of Lake Chad in May 2015. Inhabitants of Kangarwa, Baruwa, Chukujani, Tuwo-Indi, Ali-Kurkuri, Chuwundi, Chari-Ngawuri, and several villages on the shores, islands, and islets of the lake were forced to evacuate further north and west. This forced eviction had the effect of dispossessing the displaced of their sources of livelihood, further impoverishing them and rendering them IDPs and refugees. Dr. Hadiza KiariFougou argues that the fish trade is the single most important economic activity on Lake Chad for all its inhabitants, accounting for over 30 million lives (interview, Hadiza Kiari-Fougou, 4 November 2015). The ban on fish trade was a desperate measure, aimed at starving the insurgents of funds, as they were believed to have cornered the fish trade to fund their activities. In addition, it was generally believed that fish trucks passing in and out of Nigeria were used to launder money as well as smuggle arms and ammunition (interview, BKH, Diffa, 6 November 2015). While these allegations may appear plausible, none of them had been substantiated. The fish trade was transnational, a huge money-earner for traders and transporters, locals as well as foreigners, and a revenue earner for governments. According to Tchangari, the ban on fish trade has reduced the potency of the insurgency but visited heavy economic deprivations and hardship on the local populace (interview, Moussa Tchangari, Diffa, 2 November 2015). Hajja Falmata Mustafa, a 45-year-old female fish-merchant-turned-refugee, recounted how she was displaced from an island on the lake dubbed 'Liberia', in the process losing all her capital and life savings (interview, Hajja Falmata Mustafa, F., 45, Kablewa, 5 November 2015). 
Photo 12 Kablewa refugee camp, Nguigmi, Diffa Region (Photo: Kyari Mohammed)

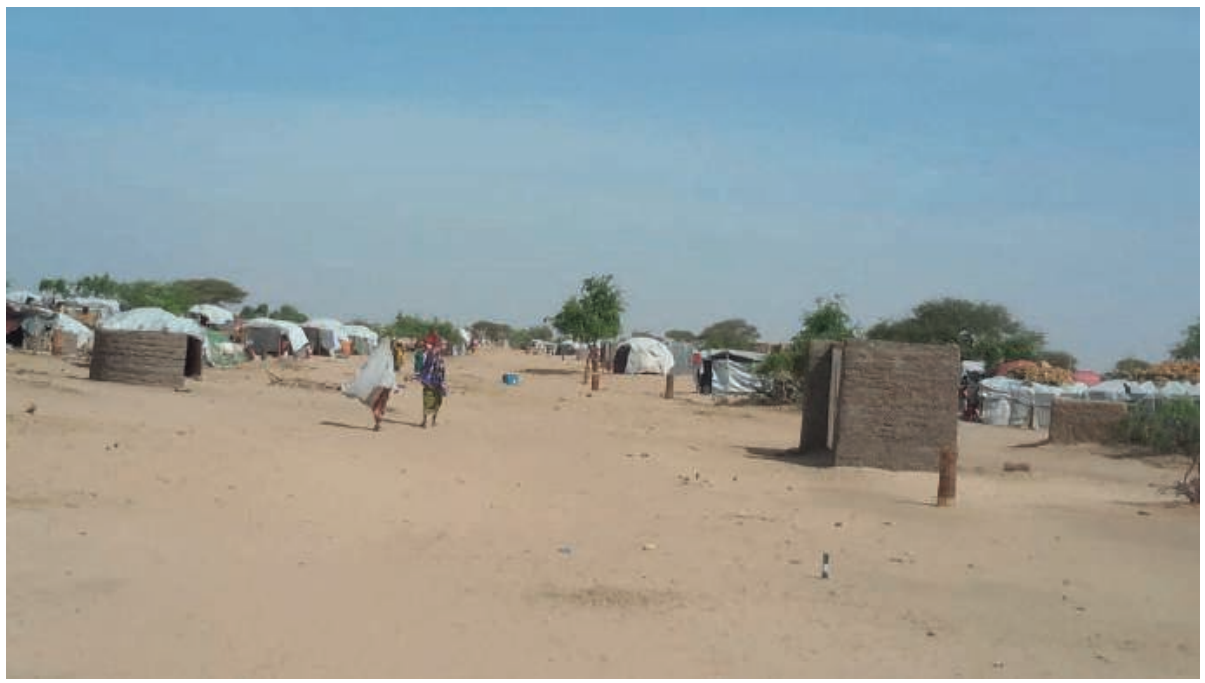

Photo 13 Internal Displaced Persons' tents in Kablewa Camp (Photo: Kyari Mohammed)

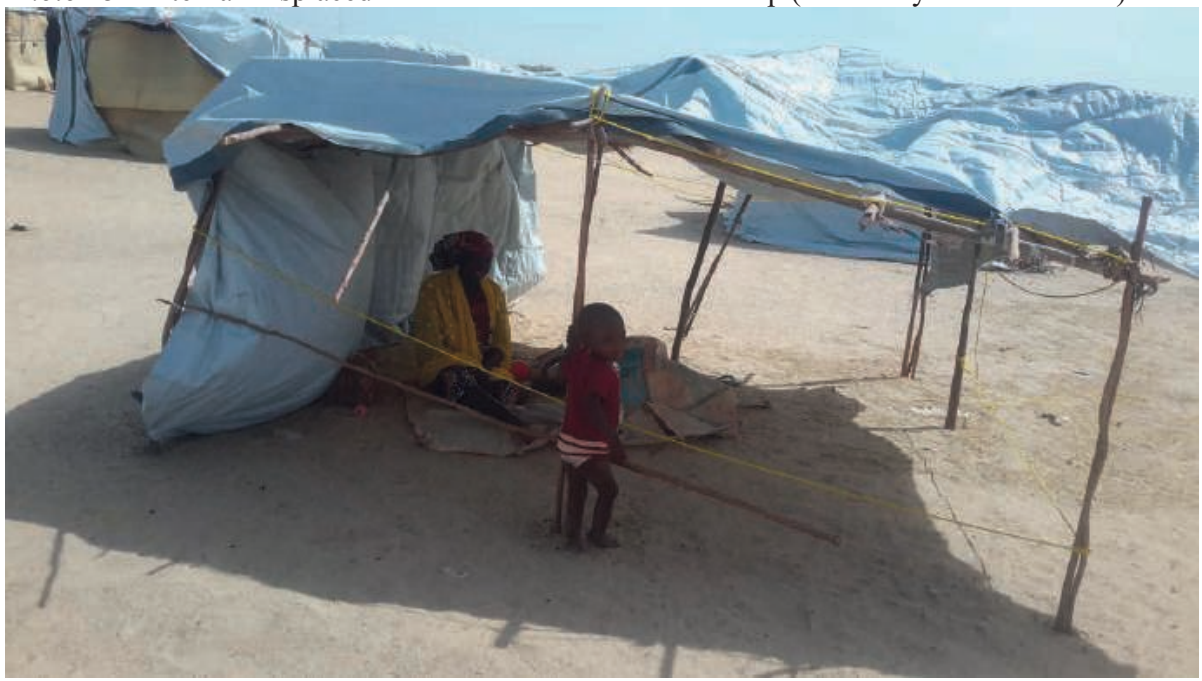

The fish and pepper trade were banned at the same time for the same reasons. Vegetable cultivation, a major occupation of the inhabitants on the courses of the Komadugu Yobe, was also banned, thus rendering large numbers of people destitute and jobless and further pauperizing an already poor population. The ban on pepper trade but not its cultivation has been lifted since August 2015. Security 
concerns had forced the military to prevent all activities along the river, such that all movements on the river were perceived as enemy movement. People were warned to keep away from the river or they would be shot on sight. The Komadugu Yobe flows right through Diffa and empties into Lake Chad after Bosso. It is also the boundary between Niger and Nigeria, and all adjoining settlements to the south of the river were still under Boko Haram control. Therefore, the military were wary of all movements on the river lest they would be surprise-attacked from that direction. The attackers of Diffa in February 2015 came from across the river. The ban on pepper trade was lifted primarily because, unlike the fish trade, this trade was local and not trans-border (interview, BKH, Diffa, 6 November 2015). Be that as it may, the trade ban has pauperized many farmers, deprived them of their sources of income, and taken a heavy toll on the local economy.

Human rights abuses by security forces, excessive force, and repression arising from the imposition of a state of emergency have been referred to above. The Alternative Espaces Citoyen in its report entitled 'État d'urgence dans la région de Diffa' of April 2015 painted a grim picture of life in the emergency-affected areas and noted these widespread abuses (Diori 2015). The Alternative Espaces Citoyen report is akin to what Amnesty International and Human Rights Watch had done on the Nigerian side, documenting serial abuses by security agencies (see Amnesty International 2011, 2012, 2013, 2014, 2015, 2016; Human Rights Watch 2012, 2013). The aerial bombardment of a gathering of mourners in Nigérien Abadam by yet-to-be-identified aircraft, killing over 40 mourners, is an example of extrajudicial killing raised by Alternative Espaces Citoyen (Diori 2015).

Diffa Region, our area of study, adjoins Borno to the east, the area worst hit by the Boko Haram insurgency. Boko Haram penetration of Niger has been relatively low and restricted to the easternmost shores of the Lake. The intensity of the conflict proportionally increases from west to east. The proximity to the Borno epicentre of the insurgency since 2009 may in part explain this. The areas of Boko Haram penetration and influence in all these countries - Nigeria, Niger, and Cameroon, with the possible exception of Chad - are ungoverned spaces, with little or no government presence. The Diffa Region of Niger, the extreme north of Cameroon, and Borno and Yobe states of Nigeria are all too far from their respective central governments, creating a feeling of alienation from the national state, with weak regional and local governance structures. There are variations from one country to the other but the absence of governance cuts across all these states. Chad is a possible exception due to the proximity of the central government in N'Djaména to the area of insurgency operations, and this in part made it less prone to attacks. This sense of alienation, combined with ethnic and regional politics, has contributed, at least in Nigeria, Cameroon, and Niger, to creating a sense of exclusion. The perception of the insurgency as political - with ethnic, 
religious, or sectional undertones aimed at destabilizing a suspicious central government - has fed into the management, or lack thereof, of the insurgency in virtually all of these countries. Fortunately for Nigeria's neighbours, the six years of conflict in Nigeria had prepared them for the eventuality.

So why has the Diffa Region of Niger, in spite of its close resemblance and proximity to Borno, remained less affected and for so long? Diffa, and therefore the Republic of Niger, was relatively unaffected for the same reasons that the north-eastern fringes of Borno were relatively unscathed until mid-2012. This period coincided with the expulsion of Boko Haram from urban Maiduguri and their subsequent dispersion further north, following intensive military pressures in areas such as Marte, Kirenowa, and Bama. Remoteness from areas of military activity was the main reason. The fall of Baga in 2014 attracted more insurgents to the north, towards Abadam, Mallam Fatori, Arege, and other settlements on the shores of Lake Chad. Increased insurgent activities on the south banks of the Komadugu Yobe opposite Diffa exposed this part of Niger to higher risks. In addition, the Nigerian military's concentrated efforts on Sambisa Forest to the south of Borno meant less attention was paid to this very rural and remote region in the so-called war against terror. The abduction of the Chibok girls in April 2014 and the general belief that they may have been hidden in this area aided this.

A recent study by the Nigerian Office of National Security Adviser (ONSA) describes Diffa as a 'remote, sparsely populated, marginalized with no ethnic homogeneity, and marked by insecurity since the 1990s' (ONSA 2015: 4). This statement can be applied to Borno, except for the ethnic plurality, which in any case is exaggerated, as most inhabitants of Diffa can get along using the Kanuri language even where they are not ethnically Kanuri, since the area is Kanuriphone. Other issues raised included the successful domestication of Islam and the entrenchment of secularism in Niger, unlike Nigeria where the concept is still being debated without a national consensus. This is in spite of the fact that Niger is $99 \%$ Muslim with less than 1\% Christian population (ONSA 2015: 9). The ONSA study avers that while poverty levels are similar in Nigeria and Niger, national figures differ substantially. This is in part because 'lower inequalities and higher levels of poverty, as in Niger, may not be as dangerous as the higher group and individual inequalities and relatively low levels of poverty, as in Nigeria' (ONSA 2015:6). Niger's strong state, political centralization, and central control of regional governments, compared with Nigeria's laissez faire and chaotic relationship between the state and society on the one hand, and lack of elite consensus in Nigeria as against Niger's politics of consensus on the other - these factors in part explain Nigeria's acrimonious religious politics. The study concludes that a more coherent state such as Niger has better capacity to regulate the religious space and contain discontent, unlike the situation in Nigeria (ONSA 
2015: 3). However, these conclusions are tentative, as Boko Haram seems to be entrenching itself deeper in Diffa, thereby making the area increasingly insecure.

In spite of Diffa's proximity and close historical, geographical, and economic links to Borno, Boko Haram's attempts quite early to proselytize and recruit in Diffa and its environs did not yield the anticipated results. The most important factors for radicalization in the Diffa area were the proximity to Boko Haram influences and activity and the continued access to Boko Haram tapes and sermons. Diffa is the nearest to the epicentre of Boko Haram influence just across the border from Damasak, and not far from Kanamma and Kilakam, both ideological centres of the sect. The suggestion that

political and economic factors are less important than ethnic and historical ones, especially because the latter create strong connections between Borno ideologues and the people of Manga, the Kanuri-speaking areas of the region of Diffa (ONSA 2015: 5)

fails to answer the question: why Diffa? The Diffa Region is predominantly Mobbar and Kanuri, with a sprinkling of Fulbe and Tubu - all of whom speak Kanuri language. The Manga areas are further west, around Goure and Zinder.

\section{Conclusion}

Boko Haram began as a local Nigerian group with distinctly local grievances but with aspirations to Islamic universalism, as expressed by violent jihadi groups such as the Taliban. It gradually expanded to become not only a security challenge to the Nigerian nation but a regional menace threatening all countries adjoining Lake Chad. In the course of the conflict, Nigeria's near neighbours - Niger, Cameroon, and Chad - gradually became sucked into the Boko Haram maelstrom. Insecurity along the long and porous borders between these countries has been a recurring problem which has necessitated bilateral and multilateral action. The MNJTF, currently engaged in the counter-insurgency operations, is one such activity. The magnitude and intensity of the Boko Haram insurgency are unprecedented and require sustained regional action and coordination.

Cross-border movements, trade, and cultural interaction have been aided by a common history, culture, tradition, and religious and ethnic affinity. This also aided Boko Haram's recruitment and radicalization across borders, since they were not seen as foreigners in the real sense. Nigeria's neighbours, which had earlier on maintained a seeming neutrality, had their relative peace and immunity broken once they became involved in the anti-terror fight as part of the MNJTF, effectively in 2014. 
Nigeria and Niger share the same characteristics and are exposed to the same risks on the Komadugu Yobe and Lake Chad axis of their borders. The response of state authorities in both Nigeria and Niger to the Boko Haram insurgency was similar in many respects. Both countries responded with coercion, and this remained the main instrument for dealing with the insurgency. There has been no attempt to apprehend the conflict in any non-military way. The use of force resulted in massive and documented human rights abuses and denial of livelihoods to residents of affected communities.

Any sustainable resolution of the Boko Haram insurgency must involve all of Nigeria's neighbours. This should involve not just military cooperation but also establishing sustainable and enduring peace and development based on justice. The reconstruction of the war-damaged areas of the Lake Chad Basin should be approached on a regional and multilateral rather than a country-specific basis. The future of inhabitants of the region and the health of Lake Chad itself are interlinked, as the lake remains their main source of livelihood. Therefore, recharging Lake Chad for fishing, agriculture, and animal husbandry should form a central part of any reconstruction process.

\section{References}

AMNESTy InTERNATIONAL (2012), Nigeria: Trapped in a Cycle of Violence. London: Amnesty International Ltd.

AmNeSty International (2014), Nigeria: More than 1,400 Killed in Armed Conflict in NorthEastern Nigeria in Early 2014. London: Amnesty International Ltd.

AMNESTy InTERNATIONAL (2015), Human Rights Under Fire: Attacks and Violations in Cameroon's Struggle with Boko Haram. London: Amnesty International Ltd.

AMNESTy InTERNATIONAL (2015), Stars on their Shoulders. Blood on their Hands: War Crimes Committed by the Nigerian Military. London: Amnesty International Ltd.

Amnesty International (2016), 'If You See It, You Will Cry': Life and Death in Giwa Barracks. London: Amnesty International Ltd.

AnONymous (2015), Deplacement force des populations des iles du Lac Tchad au Niger: Rapport de la mission d'observation de la situation humanitaire et des droits de l'Homme a Diffa et Nguigmi. Niamey: Alternative Espaces Citoyen. April.

AsIwAJu, A.I., ed., (1993), Development of Border Regions. Lagos: National Boundary Commission.

AsIWAJU, A.I. \& B.M. BARKINDO, eds, (1993), The Nigeria-Niger Border: Transborder Cooperation. Lagos: National Boundary Commission.

Borno EldERS AND LEADERS OF THOUGHT [BELT] (2011), 'Chronicle of a Few of the Several Incidents of Mass Killings and Destructions due to the Military/Police Joint Task Force (JTF) and Boko Haram Activities'. Unpublished manuscript by BELT in Maiduguri.

DIORI, I. (2015), Etat d'urgence dans la region de Diffa: Rapport de mission d'observation de la situation humanitaire et des droits de l'homme. Niamey: Alternative Espaces Citoyen. 
Human Rights Watch (2012), Spiraling Violence: Boko Haram Attacks and Security Forces Abuses in Nigeria. Human Rights Watch: USA.

IDRISSA, A., "'Boko Halal”: Why there is only limited radicalization in southern Niger Republic'. Forthcoming.

INUWA, M.M. (1993), 'The Nigeria-Niger Boundary 1890-1906: Evolution and implications for transborder socio-economic activities'. In: Asiwaju \& Barkindo, eds, The Nigeria-Niger Border: Transborder Cooperation, pp. 53-63. Lagos: National Boundary Commission.

Mohammed, K. (1995), Borno in the Rabih Years, 1893-1901. Maiduguri: University of Maiduguri Press.

Mohammed, K. (2014), 'The message and methods of Boko Haram', in Marc-Antoine Perouse de Montclos, ed., Boko Haram: Islamism, Politics, Security and the State in Nigeria, pp. 9-32. Leiden: African Studies Centre for IFRA.

ONSA (2015), Policy Brief - Violent Radicalisation in Northern Nigeria: The Macro Regional Context. Abuja: ONSA.

TIJANI, K. (1993), 'The Kanuri factor in Nigeria-Niger border relations'. In: Asiwaju \& Barkindo, eds, The Nigeria-Niger Border: Transborder Cooperation, pp. 76-90. Lagos: National Boundary Commission. 


\title{
Insert $\mathrm{C}$
}

\section{The structure and organization of Boko Haram up to $2015^{1}$}

\author{
Adam Higazi
}

Boko Haram is organized on a geographical basis, with local leaders in each town or village where it has a presence. They operate a cell structure in parts of northern Nigeria where they have members, concentrated in Borno State but with a presence that extended allegedly as far south as Okene in Kogi State. Apart from its cell-like structure, Boko Haram has a Shura Council with overall command of the organization. Members operating in different areas of Borno State (and elsewhere) could work relatively autonomously within small groups with their own leader, even if they were in contact with commanders higher up the hierarchy.

\section{Life under Boko Haram}

In 2013-2014 Boko Haram took control of more than half of Borno State and a contiguous part of Yobe State, extending its area of control to northern Adamawa State in September 2014, made possible after capturing Gwoza town (south-east Borno) on 5 August 2014. By October 2014 Boko Haram's territorial control was at its maximum extent, creating an enormous humanitarian crisis with up to 2 million people displaced as refugees and IDPs. In contrast, a year later, after regional military action and the involvement of a private security group, Boko Haram had been pushed out of most of the towns and villages they seized in 2014 (this situation was later reversed in many areas, showing that holding territory is a challenge for both sides).

In studying Boko Haram as a conflict actor, changes in the pattern of territorial control - with the insurgents and the military gaining and losing territory at different points in the conflict needs to be understood. In places that Boko Haram controlled, the organization of their authority was vividly described, during this research, by local residents who for some time were unable or unwilling to escape and lived under Boko Haram. Some lived under Boko Haram for months, others for more than a year. This section does not enter into details of the atrocities committed by Boko Haram (there were many), but rather focuses on their system of administration and social control. Two IDPs from Gwoza LGA - interviewed in Malkohi camp in Yola in October 2015 had stayed in their villages in Gwoza West (all of which fell to Boko Haram) for some months after Boko Haram took over, until they were able to escape. They and others interviewed described life under Boko Haram control.

After capturing Gwoza town on 5 August 2014 and most of the villages in Gwoza LGA, Boko Haram told those of the inhabitants who had not escaped that they were now in Daular Musulunci (Islamic State) and no longer in Nigeria. Those interviewed were from two different villages in Gwoza West: Lemu and Jaje. After Boko Haram came in, the villagers were not permitted to 'go

1 Information contained in this insert was collected in Borno and Adamawa in 2015 and relates to the situation at that time and earlier, not to the present situation, where there have been significant changes. 
to Nigeria', and if they attempted to do so - and were caught - they would be killed. Similarly, Boko Haram did not permit strangers to 'cross over' from Nigeria to Daular Musulunci. They mounted checkpoints on all the roads in and out of the areas they controlled, and they patrolled the rural hinterland, even using donkeys and horses for patrol in areas of the bush they could not access on motorcycles (petrol for motorcycles was scarce by 2014-2015). Horse-riding was banned in Borno State when President Buhari's Chief of Army Staff, General Buratai, realized that Boko Haram were using horses to get around. Boko Haram executed people they discovered travelling without permission in or out of the area. One of the ways they identified those coming in was by checking their pockets or wallet to see if they had fresh Nigerian bank notes; the notes in circulation by then in their self-declared Daular Musulunci were old and tattered.

A question was put to one of the IDPs interviewed, a man in his fifties who had lived under Boko Haram in Lemu village: 'What happened to the local population who remained in Daular Musulunci?' His response is translated from Hausa as follows:

Some of the people, those who were sympathetic to Boko Haram's cause, joined the movement. Others who did not like it had to stay because they could not leave; if they left they would be slaughtered. They stayed out of fear, because there was no way for them to move out. In all these places Boko Haram had a security network manning the roadblocks and controlling the villages. If they stopped you, you would have to identify the amir in your village and other Boko Haram officials, to show that you were living in their Daular. ${ }^{2}$

Girls and women were not given freedom of movement even within the village and were forced to wear a niqab if they had to go outside the house. If a woman was caught outside without good reason, the husband would be given a hundred lashes. Even if a girl was unmarried, if she was aged 12 or above, she had to stay in the compound all the time. If people were caught in a mixed gathering of males and females, each would get a hundred lashes. Branches from the tamarind tree would be used to give the lashes, or strips of animal hide. The elderly women were allowed to go out to farm, even if they were unmarried, from about age 65 upwards. Generally, farming and pastoral activities reduced across Borno at the height of the insurgency, leading to food shortages and hunger among IDPs and in some of the villages. There were many other prohibitions, including against smoking. It was claimed that under Boko Haram in Lemu if a man was caught smoking, he would be given 25 lashes. If caught for a second time, he would be given forty lashes - and the third time was death.

There was a shortage of basic supplies from 2014. This came about because it in many areas it was too dangerous to farm and because large sections of the rural population were displaced and tens of thousands had been killed. Fuel was also in short supply, and it was reported that in Gwoza West petrol suppliers sold it at the rate of 3,500 naira per litre in mid-2015 (when the government price in Nigeria was 87 naira per litre). Boko Haram improvised and used vegetable oil (specifically, the brand Turkey oil) to fuel their engines, especially grinding machines. When their supply of cartons of vegetable oil was cut off by the army, they forced captives to pound and extract oil from palm kernels. Otherwise fuel was brought into Daular Musulunci from people in towns outside, 'in Nigeria'. It was claimed that among soldiers, police, and civilians there were people collaborating with Boko Haram, making money from the insurgency. In Gwoza LGA, when supplies of food or fuel were scarce, Boko Haram would send women to town at night, often to Madagali, because women were less likely to be checked by the army.

In Daular Musulunci people were forced to attend Quranic classes. In the case of Lemu village - a similar situation would likely have applied in many other places - Boko Haram sent some of its members there to administer the place alongside those it forcibly recruited locally. It was reported that Boko Haram members there included Kanuris and other Borno people, a Cameroonian, and Igbos and Yorubas who were a mix of military captives and people from

2 Interview with IDP in Yola, 18 October 2015. 
townships who had been captured during Boko Haram's advance. They had been given an ultimatum to become Muslim or be killed, though it was claimed the military captives were given the choice of passing on their military know-how and training Boko Haram fighters, or converting to Islam. In general, converts were instructed for about six months in Boko Haram's ideology. However, many Muslim IDPs who escaped from Boko Haram control described the insurgents as 'hooligans' ( 'yan iska).

The punishment in Lemu village for missing a Quranic lesson was ten lashes. The young boys, girls, and older residents all had daily Quranic classes for two hours each per day. The older ones had their classes in the morning for two hours, the women from 12 noon, and the children from 4 p.m., all in separate classes. Sect members taught Quranic recitation and tawhid, about the oneness of God, and the hadiths. The subjects were things many of the villagers already knew from their existing Quranic education. Boko Haram were said to pray with their fists on the ground, instead of their hands flat. It was said that in Lemu, Boko Haram members performed the ablutions, they washed, and followed the correct qibla (direction) when praying. They had beards that had to be of a certain length - three fists in length before they could be cut - and all the men had to cut their trousers above ankle length. A 54-year-old Muslim woman who had been held captive in Sambisa for four months, however, said that Boko Haram members there performed their ablutions with sand, not water - despite, she said, there being enough water in the camp and prayed with their shoes on. ${ }^{3}$ In Sambisa - referred to as 'the reserve' - male and female members of Boko Haram prayed separately but sometimes went out to fight on the same missions. Where women fought, they would go out on motorcycles, with a group of women leading the way on their motorbikes, wielding guns, and the men on different motorbikes in their own group behind.

When Boko Haram took control of a village or town they changed the leadership there, in some places killing the existing leaders. In the case of Lemu village in Gwoza LGA, to cite one example from the hundreds of places that fell under Boko Haram control, the insurgents selected an amir from among the population of the village and forced him into that role. He had no choice but to accept, against his will, as they threatened to kill him if he refused. He had not previously been associated with Boko Haram, according to the deposed bulama (village head) whom I interviewed. The newly appointed amir was answerable to the Boko Haram leadership of the wider area, some of whom may have been local to Gwoza, while others were imposed from outside.

Shekau was referred to in Gwoza as 'alaramma' (someone who has memorized the entire Quran) and in one of the Sambisa camps as 'imam'. Boko Haram used Arabic terms for their leadership structure, which reportedly included the following positions: the imam, or overall commander of Boko Haram: Abubakar Shekau; the Q⿱ä'id ('leader', 'commander', or 'master'); Munzir ('cautioner' or 'warner'; in the Boko Haram hierarchy it may be equivalent to hakimi or district head); Naqib ('he who investigates, verifies'); Amir (appointed at the village level). An amir would be appointed either from among Boko Haram members if there were any present in that village, or selected from among the villagers by Boko Haram when they took control. The amirs were answerable to the $q \vec{a}$ 'id and munzir, according to this account, but it needs confirmation. Boko Haram also appointed alkalis (judges) and possibly other positions. The exact structure and hierarchy in the local leadership presented here still needs to be verified and more clearly understood.

In the case of Lemu village, after capturing it Boko Haram are reported to have rounded up the able-bodied young men and taken about 16 of them away for training. After training they returned to their village to help implement Boko Haram rule in the village and, it was claimed, were ready to kill for Boko Haram. The man recounting the experience said that after the Nigerian military started a counter-attack in the area, he and other villagers escaped to Madagali (which is near Gwoza, but across the state border in northern Adamawa) in August 2015. Among those who went to Madagali were the 16 youths from Lemu who had joined Boko Haram - some having

3 Interview with IDP in Yola, 17 October 2015. 
joined Boko Haram by force, some possibly voluntarily or due to a mixture of coercion and willingness. The man who provided this account said that he reported all of them as Boko Haram members to the military in Madagali, who arrested and executed them. One of his own biological sons was among the 16 he handed over, but he said that he had to do it and it was the right course of action - because his son had joined the sect and, if he left him, 'a small snake would grow into a big snake' and he could even kill his parents. It does appear that even many of those who are forced into Boko Haram are indoctrinated; and because they are made to kill people (and after some time may do so willingly), they become a threat. 


\section{Appendix}

\section{DVD sermons}

The following texts are transcripts of sermons that were filmed and then stored on DVDs. They are part of a corpus of about one hundred DVDs, collected between 2013 and 2016 during the fieldwork conducted in the cities of Zaria, Kaduna, Kano, Sokoto, and Yola - all in Nigeria; and Maradi, Zinder, Niamey, Agadez, and Arlit - all in Niger. ${ }^{4}$ The most popular preachers were identified thanks to a questionnaire filled out by sellers and customers in video stores. Featured in this appendix are excerpts of sermons from 'celebrity' preachers of the Hausa-speaking region. ${ }^{5}$

Photo 14

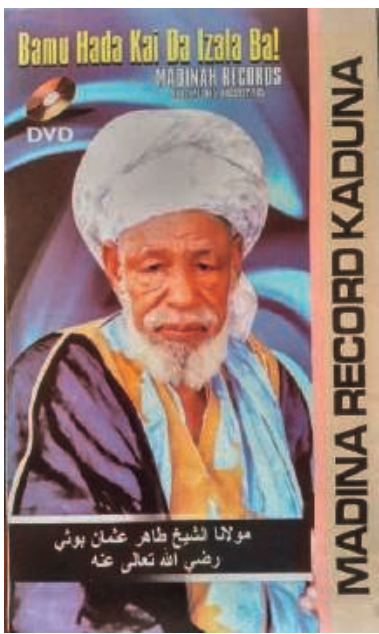

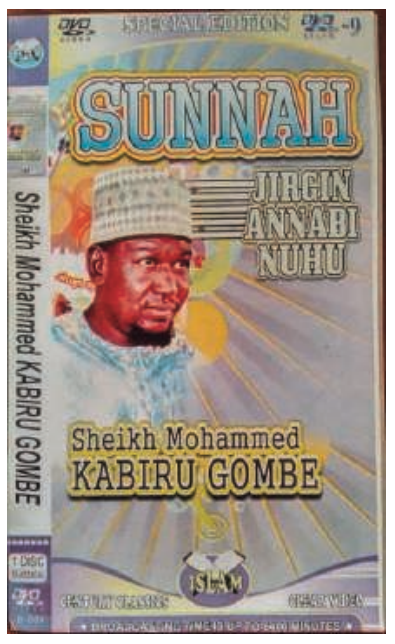

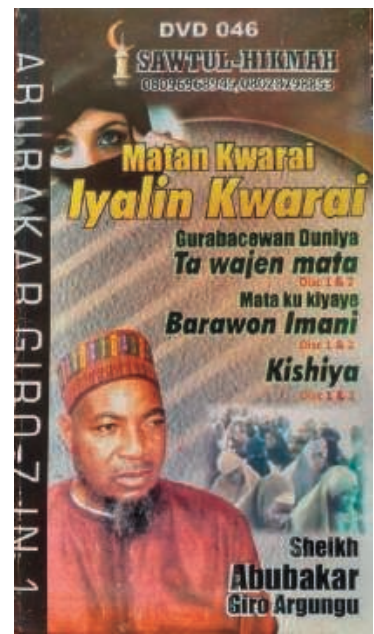

The introductions to these sermons are not included in the texts below. They usually begin with the following greeting: 'As Salam Walaykoum wa Ramatoullahi wa Barakatou' (May God's peace, mercy, and blessing be upon you), which is followed by the date and place of the sermon, then an acknowledgement of the organizers or the audience. Greetings are sometimes followed by a quotation from

\footnotetext{
4 The fieldwork in northern Nigeria and Niamey was conducted by Élodie Apard, while the work in Maradi, Zinder, Agadez, and Arlit was conducted by two research assistants: Adam Malah and Oumar Malah.

5 The sermons were viewed, translated, and transcribed by Élodie Apard and Issoufou Halarou Tankora, who translated from Hausa into French.
} 
the Quran. The following transcripts begin when the preacher starts the sermon by addressing the central theme that has been chosen for the occasion. 


\section{Sheikh Usman Dahiru Bauchi: 'Bamu Hada Kai da Izala Ba' (We do not cooperate with Izala)}

Sermon delivered for the Islamic New Year, in Bauchi Mosque

Children born into non-Muslim families must respect their parents and cannot come to Islam on their own.

$[\ldots]$

Christians are better than Izalas, ${ }^{6}$ because in recognizing them [the Tijani] as Muslims, they show respect. A Christian has never insulted a Tijani or his parents. A Christian has never used a car with loudspeakers to insult a Tijani and his parents.

Differences among Muslims should not exist. Yet, the Izalas will reject their mother or their father if they do not share the same ideals. No matter what the divisions, everyone will find their place on Judgement Day. Members of the same family cannot be separated; we must not give in to Izala propaganda. The Izalas claim that the Prophet's parents were not Muslims; associating with people who say such things is impossible [he quotes a hadith]. For the Tijani, the Prophet's parents were exemplary parents. In the Tijaniyya, great respect is shown to the Prophet's mother, Amina, who carried the Prophet for nine months.

The Izalas engage in propaganda and politics. The Tijani do not engage in politics. This is the fundamental difference between them. The Izalas play politics and put everyone in the same bag. In politics, anyone can speak out in public, even a woman, even a bastard. That's what the Izalas do; that's the curse they are bringing.

$[\ldots]$

The Tijani recognize the importance of saints because they had a direct relationship with God. They were anointed by God and He recognized their holiness. Division was brought about by the Izalas, which is the root of the current crisis and violence in Nigeria. In the past, we did have weapons, but people wouldn't fight. Today, because of these divisions, bombs are exploding all over the country.

Westernized young people who have attended the white man's school are attracted to the novel nature of the Izalas. They want something new and reject old practices, which explains the success of the Izala movement among the youths. Politics is based on the American model. The Izalas put politics before religion, therefore placing the United States before God.

6 The term 'Izala' refers to the Salafi-inspired reformist movement in northern Nigeria whose full name is 'Jama'atu Izalatul Bidi'a wa Iqamat Al Sunnah'. The diminutive 'Izala' is also used (mainly by their detractors) to refer to the members of the movement, who refer to themselves as 'Al-Sunnah' instead. 
The problem in Nigeria is that the first Izala sermons chastised the Tijaniyya and the Qadriyyah, and the political power let it happen. If government representatives had intervened, today's situation might be different.

It all began in Kaduna; the first Izala sermons accused the members of the brotherhoods of being infidels [...]. If a political voice had been heard earlier, the Izala movement would not have grown as much. The problems Nigeria encounters today have been caused to varying degrees by the Izalas. No association with the Izalas is possible. To make such association possible, they would need to stop criticizing the saints. The role played by the saints is important. When you want to get to the president, when you want to get to God, you don't talk to him directly; you don't go to him directly. That is the role of messengers and intermediaries; they are necessary steps. It's like touching a power pole: you can't touch it with your bare hands; you need gloves.

$[\ldots]$

We must not follow the Izalas in prayer; we must not go and pray in Izala mosques. We can't call them infidels, because they do pray; but as Muslims, we cannot associate with the Izalas, as this would mean forsaking the Prophet.

In Nigeria, there are Muslims, there are Christians, and then there are the Izalas. The only thing they have in common is that they constitute the population of Nigeria. But the truth will only come out on Judgement Day. 


\section{Sheikh Kabiru Gombe: 'Jirgin Annabi Nuhu' (The Ark of the prophet Noah)}

Sermon delivered in Tahoua, Niger, during a wa'azin kasa

Today we will examine al-Baqarah, one of the most important surahs. It conveys different things that should be clearly distinguished. Marabouts often have a difficult time explaining this surah properly [...].

When the angel Djibril [Gabriel] came to Mariam [Mary], he appeared to her as a young man. Mariam was cautious because she was alone in Djibril's presence at that time. This shows that Mariam was a well-behaved woman. Young people's attitude towards women today is a problem. There are idle young men who enjoy a carefree life and do not care about God. These young men approach girls and make up stories to impress them. They ask their friends to call their phone when they are with a girl so that she will believe they are businessmen. They adopt different techniques depending on the personality of the girl they are after; if the girl is religious, the boy will give her a pious speech and will try to get closer to her as the day goes by. At 8 p.m. he acts all serious with a book in Arabic, making an argument in favour of Quranic schools. By 9 p.m. he gets closer and reduces the distance between them until she is cornered against a wall. If someone comes by and asks him what he's doing to the girl, he'll say he's 'preaching to her!' [The audience laughs.]

These young men's rooms are always neat, with a bottle of fruit juice that might stay unopened for three months and will only be opened the day a girl comes. I am warning you parents against these young men, who can show great respect to fathers - by kneeling down to greet them, for example - in order to better achieve their goals. They use all sorts of techniques to avoid a parent's watchful eye, dressing up as girls, wearing the hijab ...

A word of advice: when a young person comes to your house to see your daughter, ask him who his father is, what family he comes from. After he has told you where he came from, send him home. Then, take a stick and go to his house; ask to see his father; ask him if he knows that his son has come to your house to see your daughter. Ask him if his son wants to marry your daughter; then a discussion can be had. If that is not what he intends to do, then threaten to break his knees if he ever comes to your house again.

I appeal to the marabouts of Tahoua: it is not enough to teach the Quran; young people must also be warned against this kind of attitudes. In Gombe, there is a marabout who teaches girls; he teaches them how to assess a young man's seriousness by testing his knowledge of Islam. 
Well-mannered girls cannot accept being approached by men they do not know. This was Mariam's attitude towards the angel Djibril, but he then explained that he was not human and was sent by God to give her a child. 'God has decided to give you a child without you having to sleep with a man, which is proof of His supremacy.' Mariam panicked. Djibril then explained to her that it was God's decision. That was how things were; her opinion did not matter, and her consent was not required. The angel Djibril then blew on her stomach and she found herself nine months' pregnant. She felt heavy, had trouble walking, and felt the first contractions [...]. She gave birth to the child, and Djibril spoke to her to reassure her that everything had been planned, that she had nothing to worry about. A source of water appeared, a date palm grew, and it gave her fruit [...].

A woman who has just given birth needs good food to eat and water to drink. But in Africa, we are not fortunate when it comes to that. Women suffer here. During the last month of pregnancy, a husband will buy wood to prepare hot water, porridge, and then bring a midwife who will make his wife drink potash. The woman suffers, sweats; her eyes get red. She is washed with boiled water three times, rubbed with hot water and neem leaves. The midwife will tell her that she is not brave, that in her time they knew how to handle it. But those days are over! What I'm asking you is to give good things [to pregnant women], quality tea, bread, milk, malkou ${ }^{7}$... Sometimes, she won't even get a piece of the sheep that has been sacrificed for the naming ceremony. Then she will be given plants for strength. Forget about that! Good food is what gives someone strength, not porridge full of potash!

$[\ldots]$

Trust in God is based on the certainty that God does everything, and that is the difference between Al-Sunnah and the Yan Bid'ah. ${ }^{8}$ For them, all these things are done by their saints, their shehu. ${ }^{9}$ For them, everything is the work of the shehu: rain, sun, health ... That is what sets them apart from us. The Tijani accuse us of being rich and of being funded by Saudi Arabia. But we owe our obedience to God only: the blessings are for God and God alone.

Sujada, for example, is the practice of reciting verses and asking for blessings on someone's behalf; it is performed by a person with more religious knowledge. It is a Tijani practice in that it involves the intervention of an intermediary. It's bid'ah. May Allah rebuke them! Al-Sunnah believe that you have to do things

7 Sheep's head cooked in sauce, a particularly popular dish in Niger.

8 Al-Sunnah is the general term used by reformist movements to differentiate themselves from other Muslims and to assert their attachment to the Prophetic tradition as well as to the model embodied by the Salaf, the Prophet's first companions. They refer to the members of the Sufi brotherhoods as 'Yan Bid'ah': those who engage in bid'ah (lit. 'innovation', 'novelty'), a term that refers to the introduction into Islamic practice of supposedly reprehensible innovations - i.e. practices not inherited from the Prophetic tradition but added later.

9 Shehu corresponds to the title of 'chief' in northern Nigeria. 
yourself - no need for intermediaries. Everyone must seek their own path to Paradise, unlike the Tijani who think they can be led to Paradise by their sheikhs, which allows the faithful to misbehave as they rely solely on their sheikhs to get to Paradise.

For Al-Sunnah, all you need is to put your faith in the angels, the Prophet, and God. The most important things are people's intentions, the purity of their heart and not of what they say.

$[\ldots]$

I have not been as happy as I am today here in Tahoua in a long time. I am delighted with the construction of this guest house for travelling Al-Sunnah, which began four months ago. It is a very beautiful and very large building. May Allah make the first Islamic university be built here in Tahoua. May Allah make the first Islamic hospital be built here in Tahoua. I salute the men of goodwill who are working on the building. I will not leave Tahoua without adding my own contribution. Couldn't the audience here also contribute? [To someone putting his hand in his pocket] No, wait, I'll start donating first! As in Paradise, I will go first and you will follow. [He then makes a donation, in naira, in his name and in the name of his alarama. ${ }^{10}$ A collection is then organized: security guards walk through the crowd with bags to collect donations]. Donating money brings great blessings, it is a way to make Islam grow. It's not like the Yan Bid'ah, who use that money to make protective amulets.

[...]

Bid'ah imams are a bad influence on people; they drive people crazy. They provide amulets to thieves but also give amulets to make people rich. They feed both sides! Bid'ah imams provide amulets to prostitutes - beauty amulets to attract men. They cut out pieces of shrouds in order to make those amulets.

Al-Sunnah prefer personal faith over prayers that are led from beginning to end. Not everyone is interested in praying for the harvest. Someone who is in love and is trying to win a girl over will not care about the harvest. Everyone has their own priorities and their own way of praying.

10 An alarama is someone who has memorized the entire Quran and assists with sermons by reciting (singing) verses at the preacher's request. 


\section{Abubakar Gero 'Matan Kwarai, Iyalin Kwarai’ (Good wifes, good families)}

Ramadan sermon delivered in Gwandu, Niger State, Nigeria to an exclusively female audience

Festivities are practices from the time of ignorance. [Addressing women] Your virtue goes beyond that! Bringing in griots, dancing - all these are negative practices.

Women who lived about fifty years ago did not know Islam well. They used to wear petticoats and short skirts. You should feel proud of living in an era when Islam has evolved. You should thank God for pulling you out of ignorance.

In the 1960s, weddings were family affairs that involved all of its members. At the time, parents did not mind when their daughters spent the night somewhere else. Back then, in Nigeria, there were no Quranic schools for women. Sheikh Hassan Saidu was the first to introduce a Quranic school for women. Today, thank God, women have access to Islamic knowledge and can recite verses of the Quran.

Before marrying a woman, some things must be clarified: First, it must be made clear that you are Al-Sunnah. Then the woman must wear the hijab.

In the days of ignorance, rules were not followed. Weddings were marked by ten days of festivities, music, dancing, and spending. Sometimes, the complicity between the bride and the musicians, the griots, would even lead to some obscene gestures. But those who did this in the time of ignorance are forgiven. Those who do that today, however: God is waiting for them with His stick!

Cocktails, picnics, launches, events where people go dancing, women take off their hijab, men share food with women - these are all negative practices. They are pagan, Western practices. At picnics, men smoke cigarettes, women hug their boyfriends, and those who don't are seen as village women.

Those of you who use Revlon hair products: be aware that Revlon products contain pork. In addition, women who colour their hair cannot wear the hijab correctly; they cannot perform janaba ${ }^{11}$ correctly.

In the past, before being taken to her husband, a bride would listen to music such as Michael Jackson's. These are white people's practices; it's not right. But that time is over now; the time of Islam has come, the time of charity. Today, even white people are moving away from these practices. People who convert are serious: a white woman who converts will wear beautiful clothes from Mecca and Medina.

\footnotetext{
11 A state of impurity of the body, especially after sexual intercourse. In this case janaba refers to ablutions - of the whole body - that the believer must perform before prayer.
} 
Michael Jackson's time is over; the time of Islam has come. You must get rid of your Dan Ibro ${ }^{12}$ and Dandali Soyeya ${ }^{13}$ CDs. The time of Islam has come, the time of jihad. ${ }^{14}$ Quranic schools should be full of women. Women's goal, their mission today, is to fully submit to God. Those who follow the good teachings and practices: God will take them into Paradise.

In the past, people used to parade the blood-stained sheet the day after the wedding night and would congratulate themselves over it. Congratulations would abound, coming from all over the bride's family. Today, ignorance is over. Thank God today is the time of Islam.

Take the Prophet, for example, whose wives had demanded comfort in their homes. He told them they could have all the comfort they wanted, but that he would divorce them. Starting with Aisha, he explained to her that if it was luxury she wanted, he would give it to her but he would then repudiate her. If she chose God's way and stayed with him, it meant accepting the rules: no going out to bars, no picnics, no henna at weddings. ${ }^{15}$ Festive ceremonies are what differentiates AlSunnah from those who engage in bid'ah. Aisha replied that she chose faith, happiness in the afterlife and not a life of luxury and ignorance, without even having to ask her parents for advice. The other wives of the Prophet all had the same reaction. As a result, God, who until then had addressed only men, started addressing women directly.

From the moment a marriage is sealed, no transgression is possible. Women who do not abide by the rules will be punished even before Judgement Day. Those who wear the hijab, go to Quranic school, and fast will be rewarded. Marriage is a contract. One must respect its clauses and not fall into the ease of a good life.

12 Dan Ibro is the most famous actor in 'Kannywood', the north Nigerian cinema industry. The comedies in which he plays are particularly popular in the Hausa-speaking region.

13 Dandali soyeya (lit. 'platform of love') is a very popular Hausa cultural movement (musical, literary, and video production) inspired by Indian musicals. The songs and videos celebrate love.

14 What is referred to here is probably not the external holy war, but rather the inner jihad - that which the believer leads against himself, in a quest for individual spiritual perfection.

${ }^{15}$ Wanké Ango or Wanké Amaria (washing the groom or the bride) is a practice performed during the wedding ceremony and consists in washing the feet and face of the newlyweds with henna-infused water. 


\title{
Abubakar Gero and Kabiru Gombe 'Hisabi Dole Ne' (The hijab is an obligation)
}

\author{
$1^{\text {st }}$ sermon: Abubakar Gero
}

Sermon delivered in Daura, Katsina State, on 8 July 2012, following a wedding and close to the start of Ramadan

The difference between Al-Sunnah and other branches, without getting into issues of conflict, is that Al-Sunnah consider the Prophet to be the judge of all judges in Islam. All his recommendations must be followed; he is God's messenger. God sent him because he was knowledgeable enough to become the guide. The Prophet's message must therefore be taken as it is and must not be distorted.

Concerning the act of prayer: the Prophet recommended, once prayer was over - after 'As-Salam alaykum' - not to think of yourself but to think of others first. However, an abundance of fatihas ${ }^{16}$ is often the fruit of selfishness. Al-Sunnah disagree with other branches of Islam on this point.

Good attitudes, good deeds must be done in front of witnesses. Your heart's good intentions are not enough. On Judgement Day, your neighbours will be called to testify to your good conduct. That is why you should always ask forgiveness from those you have wronged. In the afterlife, it will be too late.

[...]

It is very rare, among Al-Sunnah, to find someone who does not abide by Islamic rules. There might be one in a million. I can't really say that there are none, but it's very rare. Among Al-Sunnah, you will not find anyone who digs up the dead, engages in cannibalism or witchcraft, or drinks alcohol. However, saying that you are Al-Sunnah is not enough to guarantee you will go to Paradise. On Judgement Day, everyone's cases will be examined [...] the verdict will be rendered in a fair and equitable manner. Traders who engage in speculation, for example, will be held accountable. No negotiation and no corruption will be possible. God does not care about your social position, your status.

Some religious leaders shirk certain obligations, such as the funeral prayer. Not all of them do that, but some perform it only for celebrities. This is something that must be attended to, even for a layman. Some leaders skip the first prayer at the mosque because they are too busy. This is a serious mistake that will catch up with them on Judgement Day. It is important to gather as a group to practise religion well.

We must turn our backs on Western practices, especially when it comes to state management. By turning our backs on these practices, we gain in dignity.

16 Specific prayers for the blessing of a person, an action, or an event. 
It is important to maintain fervour and rigour in our religious practice. Married women will also be held accountable, because they make many mistakes. In cases of conflict with their husbands, some break Quranic laws to annoy their husbands - they do not wear the hijab, do not pray at the right time, or do not go to Quranic school, for example. However, marital problems have nothing to do with God.

There are women, for example, who now have a knowledge of the divine precepts and have remained confined to their homes - one of whom has remained in her home for 44 years - while many women go out all the time and commit sins, fornication in particular.

Some practices must be carried out in groups - such as prayer, which has more value when it is collective, since each person can make sure of the seriousness of the other - but not all. Some practices must remain individual in order to avoid sinning.

$[\ldots]$

We must look at the prophets for inspiration. They too were made of flesh and blood; they too had desires yet managed to control them and avoided shame on Judgement Day. We should emulate them. No matter which group you belong to [Tijaniyya, Qadriyya, Al-Sunnah], God will study your case in the same way. Having an important social position among Al-Sunnah does not count.

Jews and Christians are also descendants of the prophets. On Judgement Day, God will judge the attitude of everyone and will determine whether they have followed His precepts or not.

One shouldn't cling to or follow someone, give them more importance, simply because of their status. For example, during holiday prayers, especially at the end of Ramadan, the leaders' bodyguards hold umbrellas to shield them from the sun while they are praying, while they [the bodyguards] are not praying. They must drop this useless overzealousness and pray too.

$2^{\text {nd }}$ sermon: Kabiru Gombe

Sermon delivered in Abuja, Federal Capital Territory.

Looking at the crowd before me, I see 80 per cent young people. I am happy to see that the youth has left the movements engaging in bid'ah and that they are shunning vulgar practices and depravity. Educated young people follow AlSunnah movement.

Youth unemployment is a very worrisome phenomenon. Idleness leads to bad behaviours, such as delinquency, theft, lying. Such phenomena have been brought about by the advent of politics: during election times, politicians give away money to young people; then the government turns its back on them. So, what should a young person look for? They should first search for knowledge - religious 
knowledge being the most important of all, as it surpasses all other forms of knowledge; it protects you from ignorance. Whatever your rank, status, job whether you are a businessman, a lawyer, an administrator - if you have not gained Islamic knowledge, you are ignorant.

Islamic knowledge gives you the ability to resist temptation, from embezzlement, corruption.

$[\ldots]$

I ask young people to prepare themselves, first to seek Islamic knowledge, then to seek scientific knowledge. Nigeria needs doctors; we need midwives. We should avoid having men deliver babies who will see your wife naked, touch her - men who may not even be Muslims! To a Muslim, having a non-Muslim touch or see his wife is a great shame, so we need to have many doctors among us. Today, in Nigeria's hospitals, there are very few Muslim doctors. We also need Muslim engineers. In some cities in Nigeria, Muslims are in charge of sanitation work, which is not normal.

Young people also need to learn other languages. The Prophet, in his time, encouraged the learning of Hebrew. Youth is the best time to learn, because the mind is awake. We need qualified young people to meet the challenge of this technology-dominated world. Mobile phones are made by Chinese high school students in China, not by Muslims. When you can't reach your correspondent, you hear a female voice telling you that 'the number you have dialled ...' [He imitates a high-pitched female voice; the audience laughs.] If Muslims were the ones making mobile phones, you'd hear a very deep male voice!

$[\ldots]$

Very often, the children of poor Muslims are the ones who do not have access to education; they start driving motorcycle taxis. Today the government is taking action against motorcycle taxis; so, tomorrow, they will control us, and we risk becoming their slaves [government slaves].

If you did not get an education, you must do business, because the Quran has never encouraged inactivity. [He quotes a verse according to which 'everyone should sell what he has'.]

Inactivity has serious consequences; unemployed young men prostitute themselves to rich women whose politician husbands do not have time to take care of them. Also, homosexual practices are developing, particularly in Abuja.

Some young people refuse activities such as sewing, yet they don't mind begging. But the prophet Idris himself was a tailor. Who can say that they are better than the prophet Idris? The prophet Nuhu and the prophet Zakaria were both carpenters; the prophet Dawud was a blacksmith. 
Instead of creating training workshops in which young people could learn, they are scattered across the country [in reference to NYSC - the National Youth Service Corps] and do nothing. [...]

Our mission is to develop the training of young people, teach them a trade, the Quran, and how to conduct business.

The state demands social cohesion but does not provide the means to implement it. In Kaduna, for example, more than 8,000 women have orphans they can't afford to raise. There are more than 9 million beggars in northern Nigeria. The almajirai are mistreated, while those who have chosen to attend the white man's schools are better treated. There are state structures provided for secular schools, while nothing is provided for the students of Quranic schools, who are left to cope on their own. This difference in treatment is unfair. [...] There are even reckless, irresponsible marabouts who mistreat children, sometimes to the point of death. But no prophet has ever had to learn the Quran this way, nor have we, Al-Sunnah, had to take this path to learn the Quran.

When a child is born, the parents are primarily responsible - especially the father, who is responsible for his child's education. There is a division of labour: women are in charge of carrying the child for nine months, while men are in charge of their education. Quranic school is sometimes seen as an opportunity for fathers to shirk their responsibilities. We have a responsibility to take care of these abandoned children and to teach them the Quran. [...] Failing to do so would be betraying them.

It is possible for someone to learn the Quran, learn a trade, and take classes on the side. [...]

We have to adapt, to change our strategy, to teach the Quran to our children, but also what they are taught in the white man's schools. When there are educated Muslims within state institutions, then things will finally change. 


\section{How We Published This Book Sustainably}

As the African Studies Centre Leiden it is our desire to produce and spread a wide range of Africa related knowledge that will inform, inspire and motivate readers from all generations. However, knowledge production can have unintentional but damaging and irreversible side effects to the environment. Unnecessary use of harmful materials, polluting transportation methods and the use of toxic substances in printing techniques are just a few examples of how hard copy books can be more harmful to the environment than they look at first sight.

We want our future generation to enjoy our publications just as much as the current generation. That is why the African Studies Centre Leiden wants to publish its work in the most sustainable way, with an eye for the natural environment and all living organisms that live in it.

This book was printed on (Munken Premium Cream) paper, made from trees from a sustainably managed production forest. We used glue that is less burdensome to the environment than conventional book glue. Finally, our book cover is made from recycled plastic.

Do you want to contribute to sustainability yourself? Please pass this book on to others after you finished it.And if you have any further suggestions how to make this book more sustainable, please let us know!

\section{African Studies Centre Leiden}

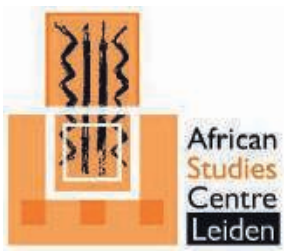





\section{West African Politics and Society series 4}

At the crossroads of major trade routes and characterised by intense human circulations, the area that encompasses northern Nigeria and southern Niger is a privileged space to study transnational religious dynamics. Islam is, indeed, an essential feature of this region assuming today new forms in terms of discourses, practices, and modes of dissemination. In order to capture their changing complexity and diversity, regional Islamic dynamics need to be observed from both sides of the Niger-Nigeria border, where religious patterns echo each other but also obey different socio-political injunctions. While studying the processes of religious renewal and mutation, it is necessary to pay attention to the varied forms these processes take, to their direct and indirect effects and to the channels of transmission used.

An interdisciplinary team of seven researchers from Niger, Nigeria, France and the United Kingdom was set up to conduct this transnational study; all authors carried out ethnographic fieldwork in both countries while constantly exchanging, comparing and discussing their respective findings with each other. Thus, this book provides first-hand material collected in the field, that contributes to enrich the reflexion on contemporary transformation dynamics in the Islamic landscapes of Niger and Nigeria, but also reflects the relevance of a transnational and comparative approach of these phenomena. Finally, it showcases the collaborative work of African and European scholars from Francophone and Anglophone countries - a type of scientific partnership unprecedented in this field.

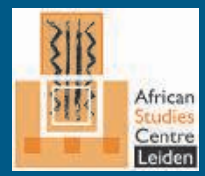

www.ascleiden.nl

\section{IFRA}

